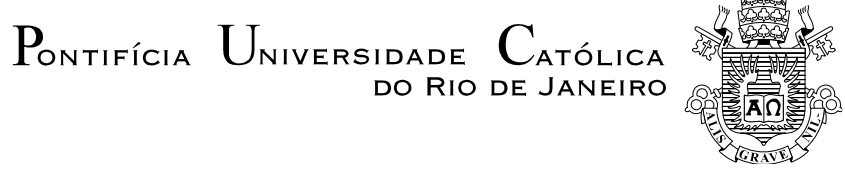

Angélica Cristina Nagel Hullen

\author{
Plano Rio Sem Miséria: reflexões \\ sobre a estratégia de superação à \\ pobreza no estado do Rio de Janeiro
}

Dissertação apresentada ao Programa de Pósgraduação em Serviço Social da PUC-Rio como requisito parcial para obtenção do título de Mestre em Serviço Social.

Orientador: Prof. Marcio Eduardo Brotto 


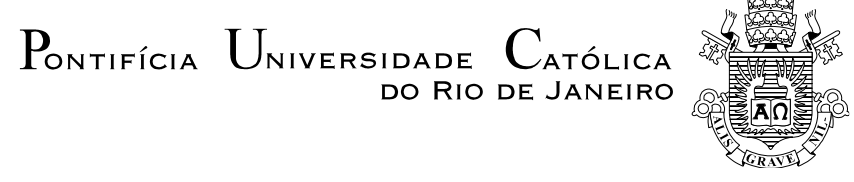

Angélica Cristina Nagel Hullen

\title{
Plano Rio Sem Miséria: reflexões sobre a estratégia de superação à pobreza no estado do Rio de Janeiro
}

\begin{abstract}
Dissertação apresentada como requisito parcial para obtenção do grau de Mestre pelo Programa de Pós-Graduação em Serviço Social do Departamento de Serviço Social do Centro de Ciências Sociais da PUC-Rio. Aprovada pela Comissão Examinadora abaixo assinada.
\end{abstract}

Prof. Marcio Eduardo Brotto

Orientador

Departamento de Serviço Social - PUC-Rio

Profa. Andreia Clapp Salvador

PUC-Rio

Profa. Fátima Valéria Ferreira de Souza

UFRJ

Profa. Sindely Chahim de Avellar Alchorme Prefeitura da Cidade do Rio de Janeiro

Profa. Mônica Herz

Vice-Decana de Pós-Graduação do Centro de Ciências Sociais - PỦC-Rio

Rio de Janeiro, 26 de março de 2015 
Todos os direitos reservados. É proibida a reprodução total ou parcial do trabalho sem autorização da universidade, do autor e do orientador.

\section{Angélica Cristina Nagel Hullen}

Graduou-se em Direito pela Universidade do Noroeste do Estado do Rio Grande do Sul, em 2001. Atuou como Gerente Executiva do Programa Bolsa Família em Boa Vista-RR de 2007 a 2009. De 2009 a 2013 foi suporte operacional especializado no Ministério de Desenvolvimento Social e Combate à Fome, na Secretaria Nacional de Renda e de Cidadania. Em 2011 participou da construção do DF Sem Miséria do Governo do Distrito Federal. De 2013 a 2015 atuou como especialista em políticas públicas no Governo do Estado Rio de Janeiro, na Secretaria de Estado de Assistência Social e Direitos Humanos no Plano Rio Sem Miséria e no Pronatec- Brasil Sem Miséria. Atualmente atua na Secretaria Municipal de Assistência Social e Direitos Humanos de Niterói-RJ como assessora especial. É membro do NIEPSAS- Núcleo Integrado de Estudos e Pesquisas em Seguridade e Assistência Social.

Ficha Catalográfica

Hullen, Angélica Cristina Nagel

Plano Rio Sem Miséria: reflexões sobre a estratégia de redução à pobreza no estado do Rio de Janeiro / Angélica Cristina Nagel Hullen ; orientador: Márcio Eduardo Brotto. - 2015. 322 f. : il.(color.) ; $30 \mathrm{~cm}$

Dissertação (mestrado)-Pontifícia Universidade Católica do Rio de Janeiro, Departamento de Serviço Social, 2015 Inclui bibliografia.

1. Serviço social - Teses. 2. Pobreza. 3. Assistência Social. 4. Plano Rio Sem Miséria. I. Brotto, Márcio Eduardo. II. Pontifícia Universidade Católica do Rio de Janeiro. Departamento de Serviço Social. III. Título. 
A Cassiano, Daniel, Rafael e Sofia, minha razão de ser e de tudo que faço: fincam meus pés no chão e acalentam o meu coração. 


\section{Agradecimentos}

Agradecer é reconhecer o apoio das pessoas, é partilhar satisfação, gratidão e, sobretudo ter a certeza que não se consegue vencer desafios individualmente. Este trabalho só foi possível graças ás pessoas que, de diversas maneiras e em diferentes momentos, colaboraram para que fosse realizado. A elas, os meus sinceros agradecimentos.

A Deus, minha fortaleza.

Ao meu amado Gilson, amigo e companheiro, que sempre me apoiou e incentivou e sem cujo amor, carinho, dedicação e compreensão não seria possível concluir essa etapa.

À minha mãe que não mais fisicamente conosco, mas que sei que me acalenta nas horas em que mais preciso. E ao meu pai Erton, que soube me mostrar quanto vale a pena viver com honestidade, respeito e dignidade. 
Á minha vó Arcena, querida e amada, pelo amor e apoio, acreditando que esse sonho seria realizado.

À minha sogra Gilda, pelo apoio, confiança, amor e torcida incondicionais.

Ao $\operatorname{Prof}^{\mathrm{o}} \operatorname{Dr}^{\mathrm{o}}$ Márcio Brotto, meu orientador e amigo, cuja competência intelectual e didática me acolheu com discernimento e firmeza, permitindo-me trilhar o caminho, transpor pequenas e grandes barreiras. A minha eterna gratidão e o meu reconhecimento pela compreensão e por todos os conhecimentos repassados.

À minha amiga-irmã Tânia Almeida, pelo companheirismo, amizade e apoio em todas as horas.

À minha cunhada Cristina, pela amizade e apoio. Obrigada pelas nossas longas conversas e pelo ânimo e solidariedade nos momentos difíceis.

À Natália Limongi, amiga e companheira de mestrado, pelos bons e difíceis momentos e companhia neste longo caminho que juntas trilhamos em busca do conhecimento.

A Antonio Claret, Subsecretário da SSIPS, pela sua integridade e senso de justiça, por seu apoio intelectual, amizade, carinho e confiança.

À Ana Vieira, Superintendente da SSIPS, pelo seu apoio e disponibilidade para longas entrevistas e conversas. Minha admiração pela sua profunda dedicação profissional, se tornando uma referência na execução de políticas públicas.

A Luis Gustavo, Superintendente da SSIPS, pela disponibilidade para as entrevistas e para as nossas conversas que muito ajudaram a presente pesquisa.

À Enzo, Aline, Alexandra, Raquel, Mônica, Larissa e Bia, pela confiança, apoio e pelo ambiente de trabalho favorável ao desenvolvimento deste estudo. E a toda a equipe da SSIPS pela torcida e carinho. 
Às Professoras Doutoras Andreia Clapp, Fátima Valéria e Sindely Alchorne, minha brilhante banca de qualificação, agradeço as maravilhosas sugestões e críticas que enriquecem o meu trabalho e cujas contribuições foram fundamentais para a finalização desta pesquisa.

Aos professores do Mestrado, imprescindíveis na transmissão de conhecimento, rigorosos na exigência da busca do saber.

À Joana, Bruno e demais funcionários do Departamento de Serviço Social da PUC-Rio, pelo carinho, atenção e apoio logístico ao longo da minha permanência no Mestrado.

Aos colegas do mestrado, pela convivência, pelas discussões calorosas e inflamadas, que permitiram ampliar o aprendizado e a descobrir que poucos sabemos.

E a todas as pessoas que, direta ou indiretamente, me ajudaram e incentivaram a busca pelo conhecimento, vibrando com cada vitória. A todos a minha gratidão e que Deus, na sua infinita bondade, retribua a vocês em dobro todos os gestos de carinho e amizade a mim dedicados. 


\section{Resumo}

Hullen, Angélica Cristina Nagel; Brotto, Márcio Eduardo. Plano Rio Sem Miséria: reflexões sobre a estratégia de redução à pobreza no estado do Rio de Janeiro. Rio de Janeiro, 2015. 322p. Dissertação de Mestrado Departamento de Serviço Social, Pontifícia Universidade Católica do Rio de Janeiro.

Este estudo tem como objeto a análise do Plano Rio Sem Miséria-PRSM o plano, para o enfretamento a pobreza do Governo do Estado do Rio de Janeiro, com o objetivo de conhecer suas características, bem como, o processo de implementação e gestão. Propõe-se, a partir deste cenário, a tecer reflexões sobre suas potenciais contribuições para a redução da pobreza no Estado. O trajeto teórico metodológico explora a relação dialética entre pobreza e as estratégias implementadas no Brasil para o seu enfretamento, após Constituição Federal de 1988, especialmente com o estabelecimento da política de Assistência Social. A luz do referencial teórico, a pesquisa examina as concepções de pobreza monetária, necessidade e privação de capacidades - assim como, sua mensuração e relação com a proteção social e Estado de Bem Estar Social. Em sequência, traçamos um perfil das políticas no Brasil para o enfretamento da pobreza, abordando: Programas de Transferência de Renda, Fome Zero, Programa Bolsa Família e Plano Brasil Sem Miséria - aqui consideradas como antecedentes do PRMS. A partir deste panorama, o estudo explora o Plano Rio Sem Miséria e suas estratégias: o Programa Renda Melhor, o Programa Renda Melhor Jovem, a Gestão de Oportunidades Econômicas e Sociais e Acompanhamento Familiar e Fortalecimento do SUAS. A análise das estratégias nos revela que o Plano possui potencial para contribuir com a redução da pobreza no Estado do Rio Janeiro e partir desta premisse traçamos as principais potencialidades do Plano, dentre as quais se destacam o alcance da estratégia, a utilização do conceito de renda presumida e o fato da ação estar alinhada com a plataforma do Governo Federal: o Programa Bolsa Família e o Cadastro Único - no que pode ser chamado de novo federalismo social. Estes desdobramentos também nos permitem concluir que para além de potencialidades o Plano possui desafios que precisam ser alcançados, 
dentre os quais são de extrema importância o avanço de todas as estratégias, a integração e a intersetorialidade entre o poder público, o setor privado e sociedade, bem como a aproximação entre benefícios e serviços, fazendo assim com que as famílias e pessoas possam acessar direitos básicos, desenvolvendo desta maneira as suas capacidades e potencialidades e atendendo as suas necessidades. $\mathrm{O}$ estudo considera assim que o combate à pobreza não pode ser apenas uma ação da política de Assistência Social, mas sim das políticas públicas, para que de fato se tenhas perspectivas para a sua redução.

\section{Palavras-chave}

Pobreza; Assistência Social; Plano Rio Sem Miséria. 


\section{Abstract}

Hullen, Angélica Cristina Nagel; Brotto, Márcio Eduardo (Advisor). Plan Rio Without Poverty: Reflections on the poverty reduction strategy in the state of Rio de Janeiro. Rio de Janeiro, 2015. 322p. MSc. Dissertation - Departamento de Serviço Social, Pontifícia Universidade Católica do Rio de Janeiro.

This study has the purpose of analyzing the Plan Rio Without PovertyPRSM, for coping the State Government of poverty in Rio de Janeiro, in order to know their characteristics, as well as the process of implementation and management. It is proposed, from this scenario, the weave reflections on their potential contribution to the reduction of poverty in the state. The methodological theoretical path explores the dialectical relationship between poverty and the strategies implemented in Brazil for your coping, after the Constitution of 1988, especially with the establishment of social assistance policy. The light of the theoretical framework, the research examines the concepts of poverty - monetary, need and deprivation of capabilities - as well as its measurement and relation to social protection and State Social Welfare. In sequence, drew a profile of policies in Brazil for coping poverty, addressing: Cash Transfer Programs, Zero Hunger, Family Grant Program and Plan Brazil Without Poverty - considered here as PRMS the background. From this picture, the study explores the Rio Plan Without Poverty and strategies: the Best Income Program, the Best Young Income Program, the Economic Opportunity Management and Social and Family Strengthening Monitoring and ITS. The analysis of the strategies reveals that the Plan has the potential to contribute to poverty reduction in the State of Rio de Janeiro and from this prémisse plotted the main potentialities of the Plan, among which stand out the scope of the strategy, the use of the concept of income presumed and the fact that the action be aligned with the platform of the Federal Government: the Bolsa Família Program and the Single Registry - in what may be called the new social federalism. These developments also allow us to conclude that in addition to the Plan has potential challenges that need to be achieved, 
among which are extremely important advancement of all strategies, integration and the intersectoral approach between government, the private sector and society, and harmonization of benefits and services, thereby making families and people can access basic rights, thus developing their skills and potential and meeting their needs. The study therefore considers that the fight against poverty can not be just one share of social assistance policy but of public policy, so that in fact if you have prospects for its reduction.

\section{Keywords}

Poverty; Social Assistance; Plan Rio Without Poverty. 


\section{Sumário}

1. Introdução 24

2. Pobreza e proteção social: algumas reflexões

e distintas concepções e abordagens

2.1. Questão Social e Direitos Sociais no Brasil: do surgimento ao cenário pré-constituição de 1988

2.2. O cenário da proteção social: algumas considerações importantes

2.3. Interlocuções sobre pobreza: concepções e 60 mensuração da categoria

2.3.1. Enfoque Monetário: a renda como fator 63 preponderante

2.3.2. Necessidades básicas Insatisfeitas: o enfoque na noção das privações

2.3.3. Enfoque nas capacidades: ampliando horizontes

3. Antecedentes do Plano Rio Sem Miséria

3.1. Constituição Federal de 1988 e os avanços das políticas sociais no Brasil

3.2. Política de Assistência Social: inovação no 76 acesso aos direitos sociais

3.3. As primeiras experiências de transferência de 85 renda no Brasil 
3.4. Para além da transferência de renda, a luta contra a fome como prioridade de gestão: o Fome Zero

3.5. Programa Bolsa Família: algumas 96 considerações sobre o desenho operacional e objetivos

3.6. Plano Brasil Sem Miséria: garantia de proteção 105 e promoção social para a redução da pobreza no Brasil?

4. Plano Rio Sem Miséria: estratégia de redução à pobreza no estado do Rio de Janeiro

4.1. O cenário econômico e social do estado do Rio de Janeiro

4.2. Concepções fundantes do Plano Rio Sem Miséria

4.3. Programa Renda Melhor (PRM)

4.4. Programa Renda Melhor Jovem (PRMJ)

4.5. Gestão de Oportunidades Econômicas e Sociais (GOES)

4.6. Fortalecimento do Sistema Único Assistência Social e Acompanhamento Familiar

4.6.1. Fortalecimento do SUAS

4.6.2. Acompanhamento Familiar

5. Plano Rio Sem Miséria como estratégia para a redução da pobreza: resultados de um estudo de caso 
5.1. Contextualização do estudo de caso sobre o Plano Rio Sem Miséria

5.2. Apresentação e análise dos resultados do 188 estudo de caso sobre o Plano Rio Sem Miséria

6. Conclusão 233

7. Referências bibliográficas 242

8. Anexos 254 


\section{Lista de figuras}

Figura 1- As políticas sociais no Brasil 75

Figura 2- Eixos de atuação do Plano Brasil Sem 107 Miséria

Figura 3- Inclusão Produtiva Rural no Plano Brasil Sem Miséria

Figura 4- Inclusão Produtiva Urbana no Plano Brasil Sem Miséria

Figura 5- Mapa político do estado do Rio de Janeiro

Figura 6- Componentes do Plano Rio Sem Miséria, prazos e objetivos esperados

Figura 7- Integração entre Cadastro Único, 126 Programa Bolsa Família Programa Renda Melhor

Figura 8- Estimação de renda no Programa Renda Melhor

Figura 9- Ano de adesão dos municípios ao

Programa Renda Melhor

Figura 10- Fluxo operacional do Programa Renda Melhor

Figura 11- Fluxo de pagamento do Programa Renda Melhor

Figura 12- Cartão compartilhado do Programa Bolsa Família e Programa Renda Melhor 
Figura 13- Comprovante de pagamento do Programa Bolsa Família e do Programa Renda Melhor

Figura 14- Tela do Sistema de Gestão do Programa 140 Renda Melhor -

Pesquisa de Beneficiário Renda Melhor (Resultado)

Figura 15- Quem é o jovem do Programa Renda 145 Melhor Jovem

Figura 16- Cartão do Programa Renda Melhor Jovem 149

Figura 17- Descrição dos \% de saque por ocasião do 149 pagamento do benefício do Programa Renda Melhor Jovem

Figura 18- Fluxo operacional do Programa Renda 151 Melhor Jovem

Figura 19- Tela de acesso do sistema do Programa 154 Renda Melhor Jovem para as Gestões Municipais

Figura 20- Integração entre o Programa Renda 156 Melhor Jovem e as demais estratégias do Plano Rio Sem Miséria

Figura 21- Metodologia da Gestão da Oportunidades Econômicas e Sociais

Figura 22- Mapa com 0 ano de adesão dos municípios fluminenses ao Pronatec/BSM

Figura 23- Execução do Pronatec/BSM no estado do 178 Rio de Janeiro 


\section{Lista de tabelas}

Tabela 1- Taxas de reprovação e abandono no ensino médio da Rede Pública Estadual de Educação - Rio de Janeiro

Tabela 2- Resultado do Convênio da Faetec 170

Tabela 3- Histórico da adesão dos municípios ao 175 Pronatec- BSM 


\section{Lista de quadros}

Quadro 1- Quadro referência para a pesquisa de campo

Quadro 2- Eixos articuladores do Fome Zero

Quadro 3- Condicionalidades do Programa Bolsa Família

Quadro 4- Atribuições da Instância de Controle Social no Programa Bolsa Família

Quadro 5- Descrição dos programas que compõem a estratégia de Acesso a Serviços Públicos do Plano Brasil Sem Miséria

Quadro 6- Ano de implantação o PRMJ nos municípios fluminenses 


\section{Lista de gráficos}

Gráfico 1- Evolução da pobreza e da indigência na América Latina

Gráfico 2- Riquezas no Brasil pertencentes aos respectivos extratos da população

Gráfico 3- Comparativo da evolução dos índices de Gini entre o Rio de Janeiro, São Paulo e a região sudeste

Gráfico 4- Evolução da renda per capita domiciliar dos estados brasileiros 1992/2009

Gráfico 5- I Índice de Gini no estado do Rio de Janeiro

- Comparativo 1992 e 2009

Gráfico 6- Acesso à educação por quintil de pobreza

- Rio de Janeiro 


\section{Lista de Siglas}

BPC Benefício da Prestação Continuada

CAP Caixa de Aposentadoria e Pensões

CEAS Conselho Estadual de Assistência Social

CEPAL Centro de Estudos e Pesquisas da América Latina

CIEE Centro de Integração Empresa Escola

CIT Comissão Intergestores Tripartite

CLT Consolidação da Leis Trabalhistas

CNAS Conselho Nacional de Assistência de Social

COEGEMAS Colegiado Estadual dos Gestores Municipais de Assistência Social

CRAS Centro de Referência em Assistência Social

CREAS Centro de Referência Especializada em Assistência Social

FGV $\quad$ Fundação Getúlio Vargas

GM Gabinete do Ministro

IBGE Instituto Brasileiro de Geografia e Estatística

FGTS Fundo de Garantia por Tempo de Serviço

FIRJAN Federação da Indústria do Rio de Janeiro

GOES Gestão de Oportunidades Econômicas e Sociais

IAP Instituto de Aposentadoria e Pensão

IAPM Instituto de Aposentadoria e Pensão dos Marítimos

IGD Índice de Gestão Descentralizada

SUAS I I Indice de Gestão Descentralizada do SUAS

INPC Índice Nacional de Preços ao Consumidor 


\begin{tabular}{ll} 
INPS & Instituto Nacional de Previdência Social \\
IPEA & Instituto de Pesquisas Econômicas Aplicadas \\
IRPF & Imposto de Renda sobre a Pessoa Física \\
LBA & Legião Brasileira de Assistência \\
LOAS & Lei Orgânica da Assistência Social \\
MDS & Ministério do Desenvolvimento Social e Combate à Fome \\
NIS & Número de Identificação Social \\
ONU & Organização das Nações Unidas \\
ONG'S & Organizações Não Governamentais \\
PASEP & Programa de Formação do Servidor Público \\
PBF & Programa Bolsa Família \\
PCS & Programa Comunidade Solidária \\
PIS & Programa de Integração Social \\
PNAD & Pesquisa Nacional de Amostras de Domicílios \\
PBSM & Plano Brasil Sem Miséria \\
PIB & Produto Interno Bruto \\
PNAS & Política Nacional de Assistência Social \\
PRM & Programa Renda Melhor \\
PRMJ & Programa Renda Melhor Jovem \\
PRSM & Plano Rio Sem Miséria \\
RF & Responsável familiar \\
SEASDH & Secretaria de Estado de Assistência Social e Direitos \\
SECONCl & Serviço da Construção Civil \\
SENAC & Secretaria de Estado de Educação \\
& Serviço Nacional do Comércio \\
\hline
\end{tabular}




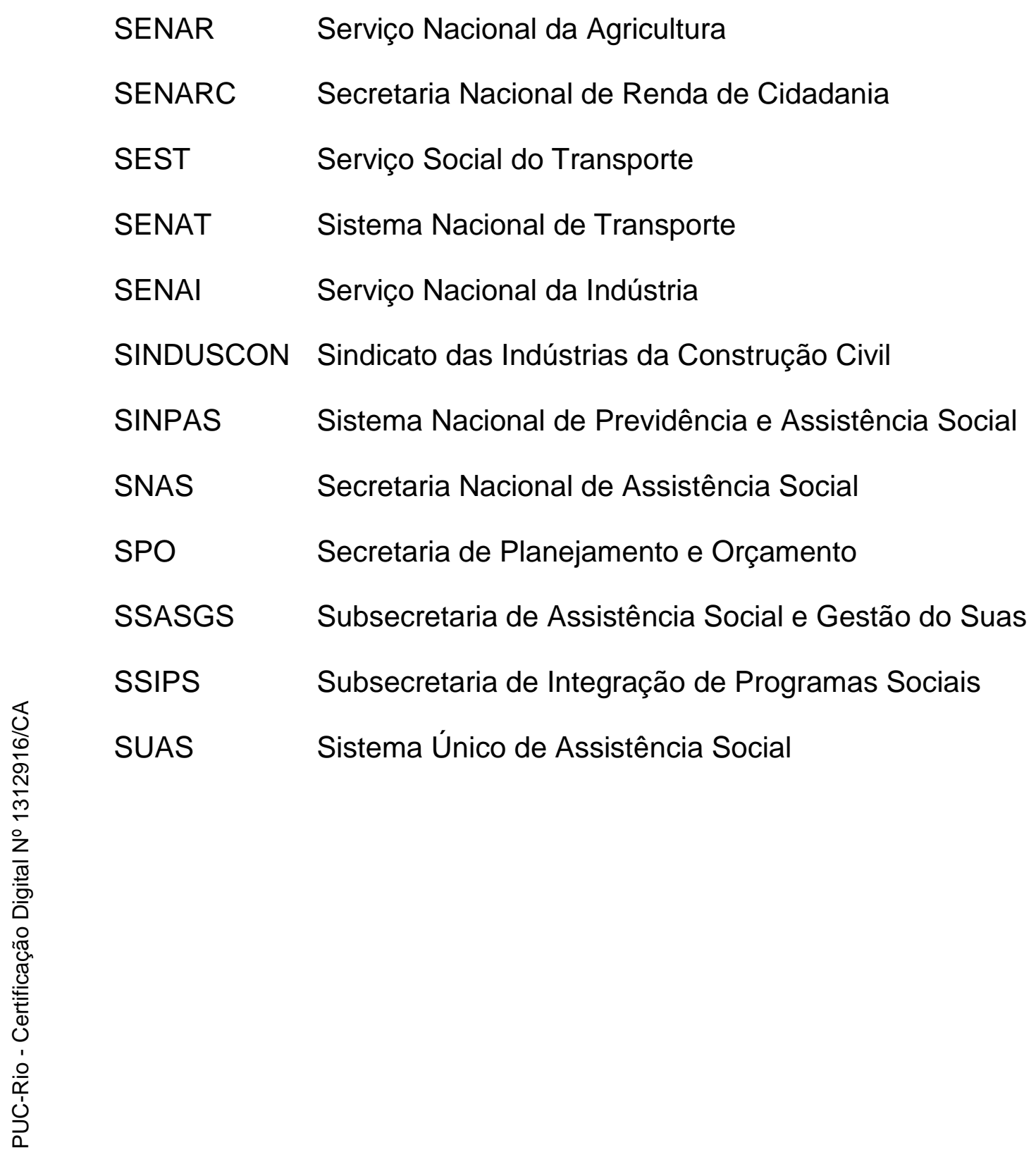


"Constitui, pois, a luta contra a fome, concebida em termos objetivos, o único caminho para a sobrevivência de nossa civilização, ameaçada em sua substância vital por seus próprios excessos, pelos abusos do poder econômico, por sua orgulhosa cegueira - numa palavra, por seu egocentrismo político, sua superada visão ptolomaica do mundo." 


\section{1 \\ Introdução}

A pobreza maciça e a desigualdade obscena são flagelos tão grandes dos nossos tempos tempos em que o mundo se gaba de progressos extraordinários na ciência, tecnologia, indústria e na acumulação da riqueza - que têm de ser colocados ao lado da escravatura e do apartheid como males sociais.

(Mandela, 2005 apud PNUD 2005, p.17).

A citação em epígrafe fala de um universo onde a pobreza e a desigualdade são os males sociais do nosso tempo e que apesar dos progressos extraordinários que o homem fez nas diversas áreas científicas, bem como a riqueza que vem acumulando, não foram suficientes nem sequer para diminuí-las. Ao contrário, foram molas propulsoras para ampliá-las, especialmente pela via da concentração de renda ${ }^{1}$.

Nos países capitalistas periféricos ${ }^{2}$, como é o caso do Brasil, a pobreza e a desigualdade são marcas históricas e consolidadas, além de paulatinamente agravadas pelas sucessivas crises econômicas e pela implementação de estratégias neoliberais, que produziram profundas reformas no Estado e aumentaram os seus indices, com destaque especial para a ampliação da extrema pobreza.

Em face do cenário acima exposto, as discussões sobre pobreza, proteção social e as políticas de transferência de renda ganham grande dimensão na contemporaneidade.

\footnotetext{
${ }^{1}$ Mais a frente, ainda na introdução teremos oportunidades de trazer alguns e reflexões sobre a concentração de renda.

${ }^{2}$ São países capitalistas periféricos aqueles cujas características em comum são a elevada dívida externa, a dependência comercial e financeira, o atraso tecnológico, os baixos níveis de educação, saúde e higiene, a baixa expectativa de vida, a elevada taxa de natalidade e a baixa renda per capita.
} 
No Brasil, a concepção era de que a pobreza seria combatida gradativamente com o avanço do progresso e do desenvolvimento econômico ${ }^{3}$. O tema, apesar de não estar ausente das preocupações e reflexões do país sobre o seu futuro, conforme observou Telles (2001), era visto como elemento quase imutável/ permanente e tinha caráter secundário, não merecendo tratamento específico.

A pobreza também não era relacionada com os padrões de formação e organização da sociedade brasileira, extremamente hierarquizada e com concentração de renda. De acordo com Jaccoub (2010), o debate não era abordado como decorrente da violência, ou da negação de direitos, ou negação de dignidade, mas sim como consequência natural da formação da sociedade, mediante o processo econômico que daria conta, por si só, de resolvê-la.

Porém, este quadro começa a apresentar sinais de mudanças, especialmente após a promulgação da Constituição Federal de 1988, quando a lei maior do país passa a prever no art. 23, inciso X, que é "competência dos entes federados combater as causas da pobreza e os fatores de marginalização promovendo a integração social dos setores desfavorecidos". Outra inovação importante trazida pela Carta Magna é a previsão da política de assistência social como componente do tripé da seguridade social, juntamente com a saúde e a previdência social.

Tal acontecimento é de suma importância, pois, a partir dele, esse tipo de proteção social passou a ser dever do Estado, desvinculando-se, em parte do formato contratual/contributivo ${ }^{4}$ que caracteriza a previdência social, para assumir

\footnotetext{
3 Antonio Delfim Netto, economista formado pela USP em 1951, participou dos governos dos generais Castello Branco (1964-1967), no Conselho Consultivo de Planejamento (Consplan); Costa e Silva (1967-1969) e Médici (1969-1973), como ministro da Fazenda; e Figueiredo (19791984), como ministro da Agricultura e secretário do Planejamento, controlando, a partir da primeira metade de 1979, o Conselho Monetário Nacional e o Banco Central. Afirmava que era preciso "fazer o bolo crescer, para depois dividi-lo", mas os benefícios econômicos não atingiram pessoas de baixa renda, que tiveram seus salários reduzidos e sua participação na renda nacional decrescida de mais de 1/6 em 1960 para menos de 1/7 em 1970.

4 No modelo contributivo os ônus do sistema ficam a cargo dos segurados, mediante o estabelecimento de tributação específica, normalmente contribuições sociais, cujos valores arrecadados verterão exclusivamente para os fins securitários. Reflete, portanto, opções políticas de minimização da participação do Estado em matéria securitária, com a individualização dos diversos riscos sociais. Logo, a proteção social neste modelo está associada ao tributo social recolhido individualmente pelo segurado, e não à cidadania, sendo a inclusão securitária implementa, em regra, mediante um sistema de capitalização. É exemplo de modelo contributivo,
} 
um propósito mais amplo e abarcar a assistência social, prevendo uma série de serviços e benefícios, com o objetivo de proteger aqueles que não podem, ou não puderam, se inserir no mercado de trabalho. Apesar das medidas de proteção social governamentais terem sido iniciadas a partir da década 1920, é com a CF/88 que a seguridade social alcançou substância e visibilidade.

Crescem também no Brasil, nos anos de 1990, os estudos ${ }^{5}$ e a preocupação na agenda das políticas públicas e, por conseguinte, a prioridade no combate não somente à pobreza, mas também as desigualdades sociais ${ }^{6}$.

Nesta década, presenciamos também mudanças na economia e no mundo do trabalho por meio da reestruturação produtiva, assim como o surgimento e/ou adensamento do neoliberalismo, que provocaram rebatimentos diretos no processo de mudanças sociais, permeado pelo desemprego estrutural, precarização do trabalho e recrudescimento da pobreza e que acabaram, de alguma maneira gerando impactos na implementação das políticas públicas.

Diante da nova realidade brasileira, os programas de transferência de renda passaram a ser defendidos pelos mais diferenciados setores da sociedade, seja do ponto de vista teórico e/ou ideológico. Os referidos programas, em especial aqueles com condicionalidades, foram desenhados como "via de solução", ou melhor, como uma estratégia de política social para enfrentar os problemas sociais.

Os programas de transferência de renda consistem em transferência direta de renda a cidadãos pobres sujeitos à comprovação da insuficiência de renda. No Brasil, sob a responsabilidade da União, foram implantados dois tipos de programas de transferência de renda: os programas sem condicionalidades como é o caso do Benefício de Prestação Continuada, o BPC, em 1996, e o Pró-Jovem em 1996; e os programas de transferência de renda com condicionalidades como é o caso do Programa de Erradicação do Trabalho Infantil - PETI (2001), Bolsa Escola (2001), Auxilio Alimentação (2001), Auxilio Gás (2001) e Cartão Alimentação (2003). Em 2003, programas de transferência de renda com

o modelo "liberal" ou residual, preferido pelos países anglo-saxões, adotado por alguns países da América Latina, com destaque o Chile que o implantou em 1981.

${ }^{5}$ Dentre os estudos podemos citar inúmeros pesquisadores como Sônia Rocha, Vera Telles, Ricardo Henriques, Ricardo Paes de Barros. Várias universidades formaram núcleos de pesquisa e estudos, assim como a FGV e o IPEA. 
condicionalidades foram a exceção do PETI, foram unificados e criou-se no governo do Presidente Lula, o Programa Bolsa Família- PBF.

Em 2003, a criação do Programa Bolsa Família - PBF, no Governo do Presidente Lula, que unificou os programas de transferência de renda com condicionalidades já existentes (Bolsa Escola, Auxilio Alimentação, Auxilio Gás e Vale Alimentação) tinha como objetivos garantir a segurança alimentar e nutricional e combater a pobreza diretamente e atuar na redução das desigualdades presentes no país, de maneira indireta.

No início de 2011, com a consolidação da política de Assistência Social, por meio da ampliação da rede de oferta de benefícios e serviços sócio assistenciais, bem como o PBF, próximo a atingir sua cobertura plena, mais de 28 milhões ${ }^{7}$ de pessoas haviam saído da pobreza extrema monetária. Apesar disto, 16 milhões ${ }^{8}$ de pessoas ainda permanecem na situação de extrema pobreza no Brasil.

Diante deste contexto, de um lado com a ampla expansão de políticas e programas e, por outro lado, com a persistência de números elevados de pessoas em situação de extrema pobreza, sob o Governo da Presidente Dilma, é lançado em junho de 2011, o Programa Brasil Sem Miséria - PBSM, com o objetivo audacioso de erradicar a pobreza extrema no Brasil até 2014. O Plano, ainda em vigor, prevê que as frentes de atuação devem ser realizadas de forma integrada, por um conjunto de Ministérios, secretarias e órgãos do governo federal. Além de integrar ações já existentes, com outras elaboradas especificamente em seu âmbito, o Plano tem como uma de suas diretrizes centrais o estabelecimento de parcerias com os governos estaduais e municipais, com entidades da sociedade civil e com empresas do setor privado.

Alinhado a estratégia do Governo Federal, o governo do Estado do Rio, em de Janeiro, criou em 2011 o Plano Rio Sem Miséria- PRSM, que consiste no Plano Estadual de Superação da Pobreza. Espera-se que por meio deste Plano seja possível a redução da pobreza no Estado, cujo cenário é de profundas desigualdades que se perpetuam e tendem a incidir sobre um número cada vez maior da população.

\footnotetext{
${ }^{6}$ No presente estudo não trataremos da categoria desigualdade devido a amplitude do tema.

${ }^{7}$ De acordo com o IBGE/2010 e IPEA/2010.

${ }^{8}$ Idem.
} 
O cenário do estado do Rio de Janeiro não é diferente do cenário mundial e do cenário brasileiro, marcados por profundas desigualdades sociais. Nesse contexto, é importante apresentar, ainda que brevemente, alguns dados que permitem identificar a magnitude da pobreza nas diversas esferas: no mundo, na América Latina, no Brasil e no Rio de Janeiro.

Dentre as informações disponíveis sobre pobreza em escala mundial, duas merecem destaque: mais de $805^{9}$ milhões de pessoas passam fome no mundo e mais de 2 bilhões de pessoas sofrem de desnutrição crônica. Outro dado importante se refere as crianças: de acordo com Ziegler (2013) mais de 16 mil crianças menores de cinco anos morrem de fome por dia no mundo. Percebe-se por esta breve apresentação de dados, que os números são preocupantes.

Com relação a renda, de acordo com a Organização Internacional do Trabalho (OIT), hoje, no mundo mais um 1,5 bilhão de pessoas vivem com menos de US\$1,25 por dia. O contingente de pessoas que vivem com mais de US\$1,25 e menos de U\$ 2,50 por dia é de 2,7 bilhões. Isso significa que se juntarmos os dados, temos diante de nós uma verdadeira hecatombe humana que pode ser configurada da seguinte maneira: mais de quatro bilhões de seres humanos vivem mensalmente com menos do que U\$ 75,00 ou R $\$ 200,00^{10}$. Na maior parte dos países, segundo Pogge (2014), a pobreza é maior quando medida de forma multidimensional, uma vez que a pessoa pode viver com mais de US\$1,25 por dia mas não ter acesso à escolarização e a serviços médicos básicos, como saúde por exemplo.

Outro aspecto relevante é a disparidade entre os mais ricos e mais pobres, atualmente no mundo. De acordo com o The Economist (2014), 47\% dos bens mundiais são controlados por $1 \%$ da população mundial (os chamados bilionários ${ }^{11}$ ). Se somarmos a estes os milionários ${ }^{12}$, o total de $10 \%$ da população mundial controla $83 \%$ dos bens existentes no mundo.

\footnotetext{
${ }^{9}$ De acordo com informações do Indice Global da Fome (GHI). O Índice Global da Fome, que é atualizado anualmente, é uma ferramenta desenvolvida para medir e acompanhar de maneira compreensiva à fome em nível mundial e também por países e regiões. O GHI é publicado de forma conjunta pelo IFPRI e as ONG Concern Worldwide, da Irlanda, e a Welthungerhilfe, da Alemanha.

${ }^{10}$ Pelo câmbio médio atual.

${ }^{11}$ Bilionários são aqueles que possuem fortuna superior a US\$ 1 bilhão. Atualmente temos apenas mil e sessenta bilionários no mundo (Forbes, 2014).
} 
Por outro lado, é importante destacar que apenas um terço dos países onde vive a população mais desprovida de recursos oferece políticas de proteção social, ou seja, as mesmas são ofertadas para apenas para $28 \%$ da população total nesta situação, de acordo com o Relatório Anual da ONU sobre Pobreza, publicado em 2014. As pesquisas ainda constataram que 842 milhões de pessoas (12\% da população mundial) passam fome cronicamente, 200 milhões estão desempregadas e mais de 1,5 bilhão têm emprego informal ou precário.

Nos mesmos passos do cenário mundial, a América Latina apresenta dificuldades para superar os altos índices de pobreza e desigualdade, em um contexto de mercado mundial globalizado, que impõem novas regras e dinâmicas produtivas e tecnológicas. Embora o ritmo de crescimento dos países latino americanos tenha modificado as condições de vida da população nos anos de 1950 e 1970, este não foi suficiente para dar conta da excessiva demanda e extrema desigualdade entre distintos países e em diversos sociais e regionais internos. A acentuada desigualdade e a exclusão social produzem núcleos duros da pobreza, estratos sociais nos quais a pobreza se reproduz de geração em geração, apresentando alto grau de vulnerabilidade.

De acordo com o Panorama Social da América Latina CEPAL (2014), em 1990, 95 milhões de pessoas (22,6\%), encontravam-se abaixo da linha de indigência e 204 milhões (48,4\%) era extremamente pobres. Em 2014, são 71 milhões de indigentes (12\%) e 167 milhões (28\%), vivendo abaixo da linha da pobreza na América Latina, conforme podemos observar nos gráficos abaixo

\footnotetext{
${ }^{12}$ De acordo com a Forbes, milionário é aquele que possui mais de US\$ 1 milhão. Hoje, no mundo existem 24 milhões de milionários.
} 

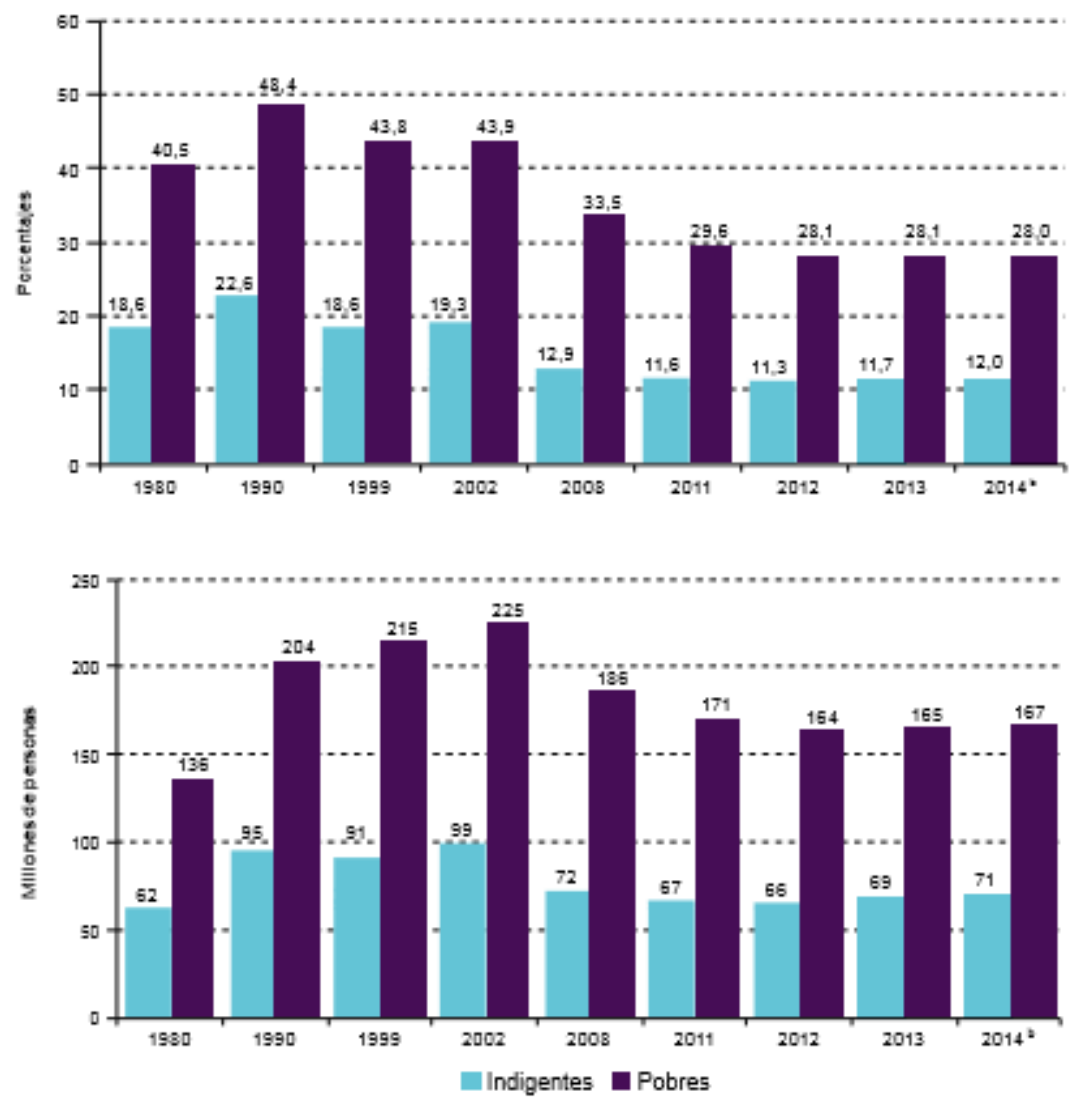

Gráfico 1- Evolução da pobreza e da indigência na América Latina Fonte: CEPAL, 2014.

Entre 1990 e 2013 a pobreza caiu 12,6 \% e a indigência 7,1\%, o que mostra que a situação tem melhorado consideravelmente. Essas melhorias devemse a um conjunto de fatores que vão desde o crescimento do PIB, a implantação de políticas públicas de proteção social, como os programas de transferência de renda e demais ações dos governos latino americanos. Porém, observamos que a pobreza e a indigência na atualidade estão estagnadas, ou seja, a redução chegou ao seu limite, (CEPAL, 2014, p.15).

Como se señala en Pactos para la igualdad: hacia un futuro sostenible (CEPAL, 2014), los países de América Latina y el Caribe enfrentan hoy el reto de seguir impulsando los progresos significativos en la reducción de la pobreza y el desempleo, así como ampliar los incipientes avances en la distribución del ingreso, alcanzados en conjunto con la consolidación democrática, la estabilidad macroeconómica y las políticas sociales. Dichos logros parecen estar encontrando límites, ya sea para sostenerse o para expandirse. Estos límites se traducen en la disminución del ritmo o el estancamiento de los procesos de reducción de la pobreza y la indigencia, y de mejora de la distribución del ingreso, especialmente después de la crisis internacional de 2008. (CEPAL, 2014, p.15). 
Observando a situação ${ }^{13}$ da América Latina sob o ponto de vista da desigualdade, os $20 \%$ mais ricos se apropriam 19,3 vezes a mais da riqueza e da renda no continente, em comparação aos $20 \%$ mais pobres. No Brasil, de acordo com a PNAD, o contingente de $1 \%$ dos brasileiros mais ricos ainda ganha quase cem vezes mais que os $10 \%$ mais pobres. A renda média é de $\mathrm{R} \$ 235,00$ por mês entre os 8,6 milhões de trabalhadores mais pobres, contra $\mathrm{R} \$ 20.312,00$ entre os 864 mil no topo da pirâmide, demonstrando a extrema desigualdade.

De acordo com Rocha (2001), a situação no Brasil não destoa do cenário da América Latina. No pais, o agravamento da pobreza ocorreu sob conjunturas bastante diferentes, tanto durante os anos de forte crescimento do "milagre econômico", na década de 70, quanto nos anos 1980, um período de inflação alta e baixo crescimento. A tendência de queda sustentada começa em meados dos anos 1990, lembra a economista, e foi consistente em fases macroeconômicas distintas, tanto durante o governo Fernando Henrique Cardoso quanto nos dois mandatos de Luiz Inácio Lula da Silva. Rocha, afirma que:

\begin{abstract}
Na primeira fase, quando o rendimento caía, os pobres perdiam menos, ou não perdiam, se ganhassem algo em torno de um salário mínimo. Na segunda, quando todos os rendimentos aumentaram, a renda daqueles na base de distribuição subiu muito mais que a do extremo superior. (Rocha, 2013, p.10)
\end{abstract}

O pesquisador Ricardo Henriques (2003) salienta que no Brasil, ainda que em 30 anos, tenha-se alterado profundamente a estrutura social e urbana do país, constituindo-se uma infraestrutura básica e com grandes capacidades instaladas, inclusive em setores de ponta, o país não apresentou projetos para uma grande massa de pobres e registra um dos piores índices mundiais relativos a concentração de renda ${ }^{14}$ e parâmetros de justiça social. A capacidade do Brasil para transformar o crescimento econômico em desenvolvimento social tem-se revelado menos que a maioria dos países latino americanos semelhantes.

\footnotetext{
${ }^{13}$ De acordo com o Relatório da CEPAL (2014).

${ }^{14}$ Ricardo Henriques afirma em seus estudos que o Brasil em 2014 está entre os 12 países mais desiguais do mundo, no que se refere a desigualdade de renda.
} 
Ainda que a década perdida tenha mostrado avanços no campo político social, com a criação e expansão de novos direitos, ${ }^{15}$ alterando o perfil e o conteúdo da proteção social, definindo novas competências, efetuando mudanças importantes no arcabouço institucional para planejamento e gestão de políticas sociais - as conquistas legais e constitucionais estão longe da universalidade de direitos (Paes de Barros, 2001).

Apesar das dificuldades, podemos destacar que a redução da pobreza e da indigência no Brasil significa que muitos brasileiros passaram a acessar os direitos básicos e por conseguinte foram incluídos numa rede de proteção social. Quanto a incidência da pobreza, ela reduziu de 48\% em 1990, para 37,5\% em 2001 e para 18,6\% em 2013. Já a indigência também decresceu, passando de $23,4 \%$ da população em 1990, para 13,2\% em 2001 e 5,9\% em 2013. ${ }^{16}$

Porém apesar da redução da pobreza, a apropriação da riqueza pelos mais ricos no país tem aumentado e, por isso precisamos apreender que pobreza e desigualdade são fenômenos diversos ${ }^{17}$. Existem países com baixos índices de pobreza absoluta ${ }^{18}$ e grande desigualdade, bem como países com grande índice de pobreza e baixos índices de desigualdade. Mas no Brasil os dois fenômenos se sobrepõem. De acordo com Henriques (2004), parte da pobreza persistente no Brasil decorre da forte desigualdade de renda. Embora os mais pobres tenham melhorado, sua participação, a distância entre os extremos pouco se alterou.

Com base em dados do IRPF, é possível estimar que, em 2012, os 50\% dos brasileiros mais pobres detinham $2 \%$ da riqueza, $36,99 \%$ ficavam com $10,60 \%$ e $13,01 \%$ com $87,40 \%$ da população. Uma parcela menor entre os mais ricos, $0,21 \%$, detinha $40,81 \%$ do total. Esta é a distribuição da riqueza no pais podemos observar no gráfico abaixo.

\footnotetext{
15 Aqui estamos nos referindo a Constituição Federal de 1988. Porém, é importante destacar, conforme veremos mais adiante na presente pesquisa que as mudanças legais não andaram em consonância com as mudanças na prática, sendo as últimas necessitando de um lapso temporal maior para serem implementadas. Exemplo disso é aprovação da Lei Orgânica da Assistência Social, lei complementar que regulamenta a política de Assistência Social no pais, que levou mais de cinco após a promulgação da $\mathrm{CF} / 88$ para ser aprovada. A aprovação da LOAS foi possível graças a ação do Ministério Público Federal no governo do Presidente Itamar Franco.

${ }^{16}$ Informações extraídas do Relatório Panorama Social da CEPAL, 2014.

${ }^{17}$ Não é objetivo deste estudo a categoria desigualdade, porém consideramos importante, efetuar uma conceituação da mesma. De acordo com Rocha (2006), um país é pobre quando há escassez de recursos. É desigual, quando há recursos e estes estão mal distribuídos, como é o caso do Brasil. ${ }^{18}$ Abordaremos o conceito de pobreza absoluta mais adiante.
} 


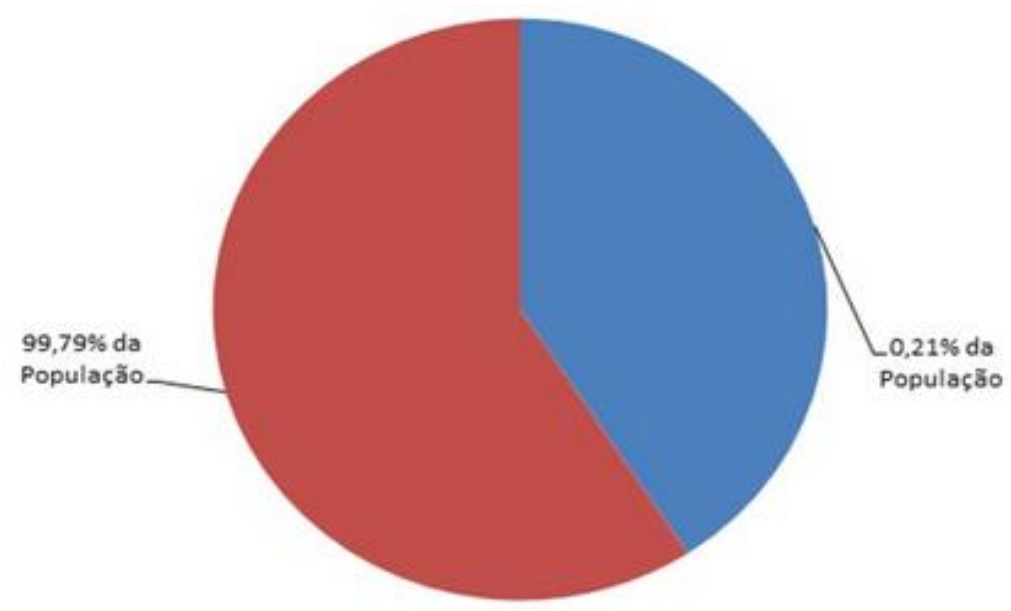

Gráfico 2- Riqueza no Brasil pertencentes aos respectivos extratos da população -2012. Fonte: Receita Federal e elaboração da autora, 2012.

Em termos de renda per capita, o Brasil não pode ser considerado um país pobre frente ao cenário internacional. Em 2010, a renda anual era de US\$ 10.237,00 (IPEA), bem superior a qualquer valor que possa ser associado a linha de pobreza. Cerca de $77 \%$ da população mundial vive em países com renda per capita inferior á brasileira. Alguns atores (Barros et. al, 2000) demonstram que no Brasil tem-se mais de $30 \%$ da população abaixo da linha de pobreza, em países com renda per capita similar à brasileira esse valor é inferior a $10 \%$, o que indicaria que parte expressiva da pobreza no Brasil não está associado à escassez de recursos, mas sim a perversa estrutura de desigualdade na distribuição de renda. Autores afirmam que a distribuição mais equitativa dos recursos disponíveis seria mais do que suficiente para eliminar toda a pobreza (Barros, et al,2000, p.20; Henriques, 2004).

Considerando-se outros indicadores além da renda, tem-se um retrato mais completo da pobreza no país. Ainda que as últimas décadas tenham apresentado avanço nos indicadores sociais do Brasil (aumento da expectativa de vida, redução da mortalidade, melhoria nos indicadores de acesso á saúde, educação, habitação e transporte), estes ainda são preocupantes. $\mathrm{O}$ índice de brasileiros com 15 anos ou mais que não sabem nem ler e escrever era de 8,6\% em 2011, tendo ligeira alta para $8,7 \%$ em 2012, caindo para 8,5 em $2013^{19}$. Mas o número de pessoas com 10 anos ou mais que não têm instrução, ou estudaram menos de um ano, subiu de 15,3 milhões para 16 milhões. Outro dado importante refere-se ao acesso ao 
saneamento básico: na comparação de um período de 12 anos, o total de domicílios com rede coletora de esgoto, incluindo os que têm fossa séptica ligada à rede, subiu 10 pontos percentuais, chegando a $64,3 \%$ no ano passado.

No estado do Rio de Janeiro, o cenário não é diferente, visto que enquanto nos outros estados da região sudeste, o índice de Gini $^{20}$ segue em uma tendência de queda, no Estado o índice permanece estagnado, demonstrando que o crescimento econômico não implica na justa distribuição de renda e na redução das desigualdades. E, mesmo com a terceira maior renda per capita média entre os estados brasileiros e o segundo maior PIB dos pais, de acordo com o censo IBGE/2010, mais de 586 mil pessoas ainda vivem com renda per capita inferior a $\mathrm{R} \$ 70,00^{21}$, colocando o Estado em $17^{\circ}$ no ranking das desigualdades entre os estados brasileiros.

Com relação a educação, ao realizamos um estudo com os quintis de pobreza, constatamos que nos $20 \%$ mais pobres do Estado, apenas $8 \%$ dos jovens conseguem concluir o ensino médio. Ainda com relação aos jovens mais pobres, $68 \%$ não conseguem concluir o ensino fundamental até 2011 e $51 \%$ destes jovens com idade de 19 a 24 anos até 2011 não haviam atingido o ensino médio.

Pode-se observar portanto, que ainda que grandes evidências tenham sido dadas às taxas de crescimento econômico como condição suficiente para a superação pobreza, especialmente a extrema pobreza, percebe-se que esta não tem sido suficientes para a redução da mesma.

E, diante de um cenário de ampliação das condições econômicas e ao mesmo, diante da presença de um número considerável de pessoas em situação de extrema pobreza, no estado do Rio de Janeiro, é criado o Plano Rio Sem Miséria com o objetivo de superar ${ }^{22}$ a pobreza. Por isso, a relevância da escolha do tema:

\footnotetext{
${ }^{19}$ De acordo com a PNAD IBGE, 2013.

${ }^{20}$ O Coeficiente de Gini é utilizada para calcular a desigualdade de distribuição de renda qualquer distribuição. Ele consiste em um número entre 0 e 1, onde 0 corresponde à completa igualdade de renda ou rendimento (onde todos têm a mesma renda) e 1 corresponde à completa desigualdade (onde uma pessoa tem toda a renda ou rendimento, e as demais nada têm). O índice de Gini é o coeficiente expresso em pontos percentuais (é igual ao coeficiente multiplicado por 100).

${ }^{21}$ A época do lançamento do Plano o valor de corte da faixa de extrema pobreza. Hoje, o valor equivale a $\mathrm{R} \$ 77,00$.

${ }^{22}$ Não concordamos com a terminologia superar, como veremos mais adiante. Utilizaremos a expressão reduzir.
} 
diante de uma experiência recente, faremos reflexões sobre a mesma, no que se refere ao seu potencial para a redução da pobreza.

Espera-se que o desenvolvimento da presente pesquisa represente mais do que uma etapa, a fim da obtenção do título de mestre: espera-se que a aprendizagem na construção do conhecimento científico possibilite uma compreensão crítica do objeto, com vistas à essência do fenômeno e a partir deste desafio, o presente estudo possa contribuir para a aproximação da Academia com a realidade social. Este é o duplo desafio que pretendemos atingir com o empreendimento acadêmico em construção.

\section{a) Delimitação do Problema}

A pergunta principal e que orienta o trabalho é a seguinte: o Plano Rio Sem Miséria tem potencial para contribuir com a redução da pobreza no Estado do Rio de Janeiro?

Para respondê-la, faz-se a análise da literatura sobre pobreza, proteção social e política de Assistência Social para extrair as categorias analíticas centrais, conformando um quadro conceitual, a partir do qual a experiência do Estado do Rio de Janeiro, o Plano Rio Sem Miséria, pode ser analisado, por meio de um estudo de caso.

Evidente que no presente trabalho não conseguimos abarcar a análise de toda a produção científica existente sobre pobreza, por isso selecionados as abordagens de pobreza relacionadas a proteção social, a construção dos direitos sociais no Brasil e as estratégias no que se refere às políticas públicas elaboradas para o seu enfrentamento. Acreditamos que outras abordagens sejam importantes e poderiam acrescentar elementos para a análise, porém houve uma necessidade de selecionar o material, para os propósitos a que se direciona o estudo, visto que do contrário, a mesma seria inviabilizada.

Para compreender a problemática da pobreza no contexto atual, o enfoque tradicional mais utilizado, baseado na pobreza apenas sob aspectos econômicas, ou aquela denominada pobreza monetária não é mais suficiente. Esse é um dos pontos de partida da construção da análise aqui pretendida. Na atualidade, já está 
consolidado que o conceito de pobreza deve ultrapassar a perspectiva monetária. Porém, é preciso deixar claro que, para o enfoque examinado, a centralidade na dimensão econômica permanece, embora essa não seja suficiente para caracterizar, por um lado e para superar, por outro, as condições de pobreza crônica. Uma análise de pobreza sob diferentes enfoques, nos dará condições de apurar elementos que tem implicação para a verificação das contribuições do Plano fluminense para a redução da pobreza.

A visão tradicional e mais utilizada sobre pobreza considera esse fenômeno a partir da dimensão de renda, do consumo, que se expressa pela identificação dos pobres a partir do estabelecimento de padrões mínimos de vida que são traduzidos em um valor monetário. Essa concepção utiliza caracteriza a pobreza como ausência ou insuficiência de renda, dimensão suficiente para identificar a privação de renda. A unidimensionalidade presente no enfoque monetário da pobreza torna-se um obstáculo para a compreensão de que a pobreza é um fenômeno multidimensional que requer uma abordagem multisetorial.

Esse é um dos primeiros pontos de análise: a renda, apesar de ser central, é insuficiente para caracterizar a pobreza, principalmente a pobreza crônica. Para avaliar se uma determinada estratégia contribui para a redução da pobreza, ela não pode prever apenas o enfoque monetário, ou seja, a redução da situação da pobreza apenas sob a concepção monetária.

Outras concepções consideram que outras dimensões seriam centrais e necessárias: pobreza é um processo que envolve dimensões políticas, sociais e culturais, sendo, portanto inadequada abordá-la apenas sob o aspecto econômico. Para uma compreensão mais abrangente de pobreza, especialmente a crônica, extensa no tempo e marcada pela intensidade de privações, é necessário incorporar outros fatores menos tangíveis, para caracterizá-la, partindo do pressuposto que a mesma se produz e reproduz, bem como quais são as condições para a sua redução.

$\mathrm{O}$ enfoque das capacidades reconhece que os processos de inclusão e redução da pobreza envolvem, além da renda, o acesso a serviços públicos e sociais de qualidade; relações sociais familiares e comunitárias de caráter mais positivo; acesso a trabalhos mais qualificados que confiram aos indivíduos não 
apenas renda, mas também a identidade e um lugar social. Além disso, é necessário viver em locais dotados de infraestrutura social.

Esse é o segundo ponto do argumento: a estratégia de intervenção para a redução da pobreza, deverá incorporar não apenas a dimensão mais tangível de bens e serviços oferecidos pelo Estado, mas também a sua dimensão relacionada com o a articulação e intersetorialidade das políticas públicas, objetivando a oferta de um conjunto completos e de qualidade no território, formando uma rede de proteção social, que tenha como um dos focos o desenvolvimento do capital humano, visto que pobreza também é fruto de serviços públicos precários, descontínuos e segmentados que acarretam processos de segregação e marginalização sócio espacial.

O terceiro ponto de argumento é que para enfrentar a pobreza estrategicamente, é imprescindível do ponto de vista, do conteúdo das políticas públicas, desenvolver ações pautadas na busca de autonomia, ampliação das capacidades ou empoderamento das pessoas, grupos e regiões. Sendo assim, é necessário criar um conjunto articulado de ações envolvendo o poder público, a iniciativa privada e a sociedade civil para que os mesmos se tornem catalisadores das mudanças, atuando na direção do emponderamento e ampliação das capacidades de escolhas e melhoria efetiva das condições e perspectivas de vida.

O ponto de chegada desse esforço consiste em descrever a formação da categoria pobreza no Brasil, por meio da descrição histórica da formação dos direitos sociais, assim como realizar uma análise da relação entre a categoria e proteção social e Estado de Bem Estar Social. Por fim é efetuada uma análise no que se refere a concepções e mensurações de pobreza. É importante a percepção que neste esforço analítico objetivamos efetuar a descrição da formação da categoria pobreza no Brasil e as concepções da mesma, que posteriormente serão utilizadas para análise do Plano Rio Sem Miséria.

A segunda parte do trabalho recorre a pesquisa documental referente aos a estratégias nacionais para o enfrentamento da pobreza após a CF/1988 e que podem ser considerados como antecedentes do Plano Rio Sem Miséria e a pobreza como desafio para as políticas públicas após a Constituição Federal de 1988: a Política de Assistência Social, os Programas de Transferência de Renda, a Fome Zero, o Programa Bolsa Família e o Plano Brasil Sem Miséria. 
Com base no quadro acima construído, e tendo como referência as categorias analíticas e os elementos explorados ao longo da primeira e da segunda parte do trabalho, tem se condições para examinar a experiência do Plano Rio Sem Miséria, o plano de enfrentamento a pobreza do estado do Rio de Janeiro, com o objetivo de identificar se o mesmo contribui para a redução da pobreza no Estado.

Quando falamos em redução da pobreza, estamos falando de um conjunto complexo de ações que perpassam o aspecto da renda, alinhando para um conjunto de acesso a bens e serviços, objetivando a ampliação das oportunidades e capacidades das famílias, bem como lhes permita a liberdade de escolhas.

A escolha do Plano Rio Sem Miséria não tem a pretensão de validar um modelo ideal de intervenção para o enfrentamento da pobreza, mas sim de prover de elementos empíricos para as categorias de análise, apontando alguns desafios, nos quais se esbarra na prática, quando se busca implementar, no nível local, as diretrizes da intersetorialidade e articulação de um lado, e do outro lado, as metodologias, os processos e a gestão do Plano, de outro. Portanto, não se trata da análise dos resultados do Plano, no sentido estrito.

A ideia central consiste em sustentar que as categorias e os elementos identificados na literatura, tanto na primeira, quanto na segunda parte do trabalho, são efetivas para o desenho, a implementação e a gestão de estratégias de redução da pobreza; e também algumas dificuldades quando se implementa de fatos tais estratégias, tendo em vista a análise realizada.

O presente trabalho identifica e situa contribuições da literatura sobre o tema concepções e mensuração da pobreza, bem como traz aspectos das políticas de enfretamento a pobreza no Brasil, especialmente após a Constituição Federal de 1988. Além disso, traz a discussão sobre a implementação da Política de Assistência Social no Brasil e a relação da mesma no enfrentamento da pobreza.

O trabalho sustenta-se em dois pontos de apoio: diante de uma concepção multidimensional e multisetorial é possível um a elaboração de um Plano para a sua redução na esfera estadual? Para tanto, são identificados os elementos centrais de uma visão multidimensional, heterogênea e o reconhecimento da necessidade de dimensões intersetoriais para a sua redução, com foco num conjunto articulado 
de estratégias que permitam a autonomia, a participação, empoderamento e ações intersetoriais e articuladas entre as diversas políticas públicas. A proposta é capturar e organizar as dimensões e categorias que emergem da literatura examinada com o objetivo de analisar, a partir do quadro assim construído, a estratégia do estado do Rio de Janeiro.

Dessa forma, a atualidade e relevância do tema, inclusive no cenário nacional e internacional ${ }^{23}$, pela experiência inovadora que o Plano representa, também foram importantes no momento de escolha do tema.

Ao se escolher o PRSM como o foco do objeto desse estudo que se pretende realizar, pensou-se na relevância do que ele significa para a temática da superação da pobreza no estado do Rio de Janeiro e no Brasil, como também para a trajetória da luta pela efetivação das políticas sociais públicas.

Este estudo acadêmico deve buscar preencher uma lacuna de pesquisa sobre políticas sociais públicas, na perspectiva da atuação integrada entre o Governo Federal, por meio do PBSM, e do Governo Estadual, por meio do PRSM para a redução da pobreza, contextualizada no debate sobre a proteção social, ação articulada com o PBF, Cadastro Único e com a política de Assistência Social, porém não tem a pretensão de esgotar a temática.

\section{b) Sobre a metodologia}

A análise de uma política pública requer uma abordagem teórica e empírica organicamente articulada, pois de acordo com Pereira (2008), há sempre influência teórica na política social, seja na interpretação, seja na sua realização.

Há uma aceitação da comunidade acadêmica de que o estudo de caso qualitativo constitui uma investigação de uma unidade específica, situada em seu contexto, selecionada segundo critérios pré-determinados e, utilizando múltiplas fontes de dados que se propõem a oferecer uma visão holística do fenômeno estudado, ou seja, sintetizando unidades em totalidades organizadas. (AlvesMazotti, 2006).

\footnotetext{
${ }^{23}$ Visitas de delegações de vários países para conhecer a experiência do PRSM: México, Haiti, Guatemala, Costa Rica, Colômbia e Venezuela.
} 
Dessa forma, na presente pesquisa será utilizada a metodologia do estudo de caso, de acordo com os "designs and methods" propostos por Robert K. Yin (1984). Yin recomenda que o estudo de caso deve ser aplicado para explicar ligações causais em intervenções ou situações da vida real, que são complexas demais para tratamento por meio de estratégias experimentais ou de levantamento de dados; bem como para descrever um contexto de vida real no qual uma intervenção ocorreu. Ora, considerando-se o PRSM como uma intervenção do poder público na sociedade fluminense, a partir de 2011, e a complexidade que um debate teórico sobre ele requer, é possível considerar também que a proposta apresentada por Yin seja a mais adequada para estudá-lo.

Com isso, é desejável que o estudo aprofunde a compreensão de um fenômeno pouco investigado, levando à "identificação de categorias de observação ou à geração de hipóteses para estudos posteriores" (Alves-Mazotti, 2006).

De forma a nortear o estudo de caso, e por se mostrar compatível com a proposta de pesquisa, utilizar-se-á, durante a coleta das evidências do estudo de caso e respectivas análises, o parâmetro proposto por Oszlak e O’Donell (1976). Eles defendem que "toda política tem um ciclo vital" e propõem que, por isso, devem ser levadas em conta:

1) As categorias analíticas básicas que neste caso, correspondem a: pobreza, proteção social, Assistência Social, Programa Bolsa Família, Plano Brasil Sem Miséria, Plano Rio Sem Miséria.

2) A transformação de problemas em questões: para buscar interpretação teórica do PRSM que estão expressas na forma dos objetivos - geral e específicos, conforme orientação de Yin (Yin, 1984);

3) $\mathrm{O}$ papel dos atores da Gestão Estadual do PRSM: será necessário conhecer como os protagonistas do PRSM (formuladores re gestores) pensam, formulam e atuam;

4) $\underline{O}$ processo de resolução das questões-problema: é preciso buscar identificar como ocorreu sua criação e implantação e como vem ocorrendo a gestão do PRSM. Além disso, é necessário captar como o Plano se articula com a política de Assistência Social, com o PBF e 
como o PBSM para a redução da pobreza no estado do Rio de Janeiro.

5) Etapas do processo de formação e desenvolvimento do Plano em estudo: compreender a totalidade do processo, com clareza de que estas etapas se superpõem constantemente e estão imbricadas umas nas outras e se atingem o objetivo a que se propõe: a redução da pobreza no estado do Rio de Janeiro.

Com base nas explanações de Kingdon (1995) sobre a importância da elaboração de um quadro de referência analítico, três níveis de análise foram identificados e deverão ser considerados para a execução da pesquisa propostas.

\begin{tabular}{|c|c|c|c|}
\hline & 1 & 2 & 3 \\
\hline O que & Pobreza & Assistência Social & $\begin{array}{l}\text { Plano Rio Sem } \\
\text { Miséria }\end{array}$ \\
\hline Quando & $\begin{array}{l}\text { Desde o surgimento } \\
\text { das manifestações da } \\
\text { questão social no } \\
\text { mundo e no Brasil, } \\
\text { até a atualidade. }\end{array}$ & Após CF/88. & $\begin{array}{l}2011-2014 \text { (desde a } \\
\text { criação do Plano até os } \\
\text { dias atuais) }\end{array}$ \\
\hline Como & $\begin{array}{l}\text { Levantando o estado } \\
\text { da arte nos termos da } \\
\text { concepções e } \\
\text { mensuração. }\end{array}$ & \begin{tabular}{|l|} 
Levantamento \\
bibliográfico em \\
termos da construção \\
da política.
\end{tabular} & $\begin{array}{l}\text { Levantamento } \\
\text { bibliográfico, análise } \\
\text { do documentos do } \\
\text { PRSM e do produto } \\
\text { das entrevistas. }\end{array}$ \\
\hline $\begin{array}{l}\text { Porque é } \\
\text { necessário }\end{array}$ & $\begin{array}{l}\text { Para realizar a análise } \\
\text { do PRSM }\end{array}$ & $\begin{array}{llr}\text { Traçar } & \text { a relação } \\
\text { entre a } & \text { política } & \text { de } \\
\text { Assistência } & \text { Social } & \text { e } \\
\text { o PRSM. } & \end{array}$ & $\begin{array}{l}\begin{array}{l}\text { Para a compreensão } \\
\text { da }\end{array} \\
\text { implantação e e gestão } \\
\text { do Plano. }\end{array}$ \\
\hline Para que & $\begin{array}{l}\text { Explicitar o debate } \\
\text { subjacente ao tema }\end{array}$ & $\begin{array}{llr}\text { Efetuar } & \text { o } & \text { debate } \\
\text { entre discutiando } & \text { a } \\
\text { relação entre } & \text { a } \\
\text { politica e o PRSM. }\end{array}$ & $\begin{array}{l}\text { Construir uma cadeia } \\
\text { de evidências que } \\
\text { reforça o impacto do } \\
\text { PRSM na redução da } \\
\text { pobreza no RJ e; } \\
\text { Elencar os desafios e } \\
\text { perspectivas futuras do } \\
\text { Plano. }\end{array}$ \\
\hline
\end{tabular}

Quadro 1- Quadro referência para a pesquisa de campo.

Fonte: elaboração da autora. 
Como instrumentos de coletas de dados, considerando estas observações preliminares, os procedimentos metodológicos para a condução deste estudo de caso devem ser executados da seguinte forma:

1. Aprofundar o conhecimento sobre o objeto de estudo, por meio dos seguintes procedimentos:

1.1. Mapeamento do universo de obras e artigos científicos sobre os temas: pobreza, proteção social, Assistência Social, Programa Bolsa Família, Plano Brasil Sem Miséria, Plano Rio Sem Miséria provenientes das fontes de referenciadas e do debate (além de ampla pesquisa nos sites scholar.google.com.br);

1.2. e da participação nos seguintes eventos:

- $\quad$ Eventos dos MDS/SENARC;

- $\quad$ Eventos da SEASDH;

1.3. Revisão de literatura, a partir do mapeamento, a fim de destacar distintas vertentes do pensamento contemporâneo e clássico sobre as categorias acima elencadas.

2. Elaborar um "protocolo" do estudo de caso, que abarque a visão geral do projeto. $\mathrm{O}$ coração do protocolo consiste em um conjunto de questões que refletem as necessidades da pesquisa. Pelo fato do debate gerado a partir dessas questões diferir daquelas formuladas para um simples levantamento, opta-se por elaborar um artigo que corresponderá ao modelo de protocolo proposto por Yin (1984), já que o autor sugere também que este exercício pode significar um "estudo de caso piloto".

As questões da pesquisa que norteiam o estudo que se pretende levar adiante são as seguintes:

- Quais os antecedentes do PRSM?

- Qual é a estrutura do PRSM?

- Como o Plano é desenvolvido/executado no Estado do Rio de Janeiro? 
- O PRSM está articulado com o PBSM? Em que medida essa articulação contribui com os objetivos do PRSM?

- De que maneira o Plano está articulado com a política de Assistência Social e de que maneira essa articulação contribui com os objetivos do Plano?

- De que maneira a articulação entre o PRSM e o Cadastro Único e o PBF contribui com a superação da pobreza no estado do RJ? ${ }^{24}$

- O Plano contribui para a redução da pobreza do estado do RJ?

- Se sim, for a resposta à pergunta acima, construir uma cadeia de evidências que comprovam que o Plano atinge seus objetivos.

- Quais os desafios do PRSM?

2.1. Elaboração de artigo sobre o PRSM e suas contribuições para a superação da pobreza no estado do Rio de Janeiro.

3. Construir uma cadeia de evidências: por meio do estudo de caso de tal modo que se consiga levar à percepção das evidências que legitimam o estudo, desde as questões de pesquisa até as conclusões finais. Isso permitirá o desenvolvimento da investigação em várias frentes (investigar vários aspectos em relação ao mesmo fenômeno). Deve-se deixar claro que as evidências foram capturadas de múltiplas fontes, cruzadas e não estão maculadas por vieses. Além disso, os potenciais problemas de validade de constructo devem ser atendidos, pois os achados, nestas condições, serão validados por meio de várias fontes de evidência, na perspectiva do parâmetro do ciclo vital das políticas, desenvolvida por Oszlak e O’Donell (1976):

\footnotetext{
${ }^{24}$ Não questionamos a presentaça da articulação entre o PRMS e o PBF e o Cadastro Único, visto que uma das condicionantes dos planos subnacionais é a sua atuação sob a plataforma do Governo Federal (PBF e Cadastro Único).
} 
3.1. Pesquisa em documentos oficiais do órgão responsável pela transferência de renda no Brasil: Secretaria Nacional de Renda de Cidadania (Senarc/MDS), bem como em órgãos de pesquisa, como o Instituto de Pesquisas Econômicas Aplicadas (Ipea), IBGE no estado do Rio de Janeiro na secretaria responsável pelo Plano Rio Sem Miséria;

3.2. Acompanhamento dos Eventos do Plano Rio Sem Miséria: lançamento do Plano nos municípios (11 reuniões) ; lançamento do Plano de Acompanhamento Familiar do Estado do Rio de Janeiro; reuniões sobre o Sistema de Gestão do Programa Renda Melhor com os municípios; reunião sobre o Portal Rio Sem Miséria com os municípios; reuniões do Renda Melhor Jovem com os municípios; reuniões do GOES com os municípios; reuniões regionais do Pronatec- BSM (8); reuniões de capacitação sobre o Plano para os municípios; reuniões de capacitação para os demais órgãos do Estado; reuniões com os ofertantes do GOES; reuniãos da CIB; reuniões com o CNAS e com o COEGEMAS;

3.3. Entrevistas abertas, tendo como referências as questões norteadoras, com os formuladores e gestores no Plano na esfera estadual. Com o intuito de se ter acesso aos entrevistados-chave ${ }^{25}$, as entrevistas deverão ser abertas, sendo estabelecidos as premissas básico, que deverão ter a sequência de acordo com as informações repassadas. Serão entrevistados:

Antônio Claret Campos Filho - Subsecretário de Integração de Programas Sociais/SEASDH;

(2) Ana Vieira - Superintendente de Renda de Cidadania/SEASDH;

\footnotetext{
${ }^{25}$ Optamos por realizar as entrevistas com o principal formulador e gestor do Plano e com os dois demais gestores do PRSM, que também foram formuladores, por julgarmos que estas entrevistas atendem às demandas necessárias para a realização da pesquisa. A entrevista com gestores nem sempre é fácil, especialmente pela disponibilidade dos mesmos. Podemos afirmar que obtivemos êxitos nas referidas entrevistas em função do acompanhamento realizado a vários eventos do Plano, bem como a disponibilidade dos Gestores para as mesmas em diversas ocasiões.
} 
(3) Gustavo Martins - Superintendente de Gestão de Oportunidades/SEASDH;

Após a realização dos procedimetos acima descritos, serão realizadas as seguintes etapas para classificação e análise dos dados:

1. Analisar as evidências: deve-se tratá-las imparcialmente, extrair conclusões analíticas e apresentar interpretações e descrições alternativas, a partir dos procedimentos metodológicos anteriormente explicitados. Conforme Yin (1984), basear-se em proposições teóricas é a forma mais comum para se analisar as evidências de um caso. O desenho e os objetivos iniciais da pesquisa estão sendo baseados sobre essas proposições, as quais refletem um conjunto de questões-problema e questões secundárias, revisão de literatura e novos insights, a fim de apontar possíveis tendências das políticas sociais na perspectiva da cidadania e do desenvolvimento. Sendo assim, as proposições iniciais descritas neste Projeto de pesquisa podem fornecer a orientação teórica que direcionará a análise do estudo. Como já destacado anteriormente, a busca da explicação deve ser intensa durante todo o processo de condução do estudo de caso. Todavia, nesta etapa, esta busca deve ser direcionada para a conclusão dos trabalhos:

- Síntese que contextualize o debate proposto sobre o Plano Rio Sem Miséria e suas contribuições para a redução da pobreza no Estado do Rio de Janeiro, com a construção de uma cadeia de evidências que faça uma síntese das mesmas, bem como exposição de perspectivas futuras para o Plano.

2. Compor o relato do estudo de caso, que, segundo Yin (1984) de ser o processo de análise e elaboração da dissertação, com a preocupação de demonstrar de modo convincente que foram empregados exaustivos esforços na coleta das evidências relevantes. 


\section{c) Organização do trabalho}

A primeira parte do trabalho tem como eixo a pobreza e proteção social. O segundo capítulo aborda a formação dos direitos sociais no Brasil, referenciando a formação da categoria pobreza. Realiza-se uma análise tendo como foco a proteção social e Estado de Bem Estar Social. A seguir, discute-se as distintas concepções e mensuração da pobreza, que se ligam. No segundo capítulo, que compõem a primeira parte do trabalho pode-se perceber que a mensuração de pobreza, refere-se ao final de contas, a identificação dos grupos destinatários das políticas de proteção social, que no caso da presente pesquisa é população do estado do Rio de Janeiro em situação de extrema pobreza, ou seja, a população beneficiária do Plano Rio Sem Miséria.

A perspectiva da construção do objeto do presente trabalho encontra ressonância em Weber e em teóricos clássicos como Pierre Bourdieu, e com essa perspectiva quer se enfatizar que o pesquisador, ao se debruçar sobre uma realidade, procede uma seleção de aspectos dessa realidade, no sentido de configurar um objetivo analítico, que não se confunde com a própria realidade, muito mais completa e disforme. A construção de um objeto sempre parte de uma concepção, uma seleção de categorias ou dimensões consideradas como relevantes para serem contrastadas com a realidade empírica. Neste trabalho, esse processo envolve uma compreensão do que é a pobreza, o que a caracteriza, como ela pode ser identificada, o que a causa, o que faz permanecer e o que é necessário para reduzi-la.

A segunda parte do trabalho centra-se num ponto distinto do debate sobre a pobreza, mais especificamente sobre as políticas de proteção social implantadas no Brasil após a Constituição Federal de 1988. O terceiro capítulo não apresenta a pobreza do ponto de vista da análise da categoria, mas das ações implementadas para o seu enfrentamento no pais e que se configuram como antecendentes do Plano Rio Sem Miséria.

O quarto capítulo focaliza as estratégias do Plano Rio Sem Miséria: o Programa Renda Melhor, o Programa Renda Melhor Jovem, a Gestão de Oportunidades Econômicas e Social e o Acompanhamento Familiar e o Fortalecimento do Sistema Único de Assistência Social. O objetivo é identificar o 
desenho da política pública em curso no estado do Rio de Janeiro, elementos do quadro analítico e o modelo de ação adotado. O quinto capítulo apresenta algumas considerações finais sobre o Plano, embora não conclusivas.

Um dos objetivos da presente pesquisa é estabelecer o nexo entre a pobreza e análise de uma estratégia para a sua redução, que é o Plano Rio Sem Miséria, algo ainda não trabalhado nos grandes conjuntos de literatura examinados. A pobreza permanece não equacionada pelos processos de desenvolvimento econômico e se soma a novas formas de vulnerabilidade e exclusão, próprias do mundo contemporâneo, e que precisa ser combatida pela estratégias implementadas, que são materializadas por meio de políticas públicas, como é o caso do PRSM.

Pensar sobre as dimensões e característica, bem como analisar as políticas de redução da pobreza com vistas a proteção social, de forma articulada, com uma reflexão aprofundada, pode ser um caminho para tornar mais evidente, principalmente para os formuladores e gestores das políticas sociais, os desafios para o enfrentamento estratégico da pobreza em âmbito local. 


\section{2 \\ Pobreza e proteção social: algumas reflexões e distintas concepções e abordagens}

\section{1. \\ Questão Social e Direitos Sociais no Brasil: do surgimento ao cenário pré-constituição de 1988}

A expressão "questão social" começou a ser utilizada na terceira década do século XIX, mais especificamente em 1830, constituindo-se em torno das grandes transformações econômicas, políticas e sociais ocorridas na Europa Ocidental e desencadeadas pelo processo de industrialização. Historicamente, a expressão foi produzida sob o ponto de vista do poder, compreendida como a ameaça que a luta de classes sociais - em especial a proletária - representava à ordem política e moral instituída (Castel, 1998).

Essa tomada de consciência foi despertada pela constatação da separação existente entre o crescimento econômico e o pauperismo, de um lado, e entre uma "ordem jurídico-política, fundada sobre o reconhecimento dos direitos dos cidadãos e uma ordem econômica negadora desses direitos, por outro lado" (Castel, 1998, p.31). Com a constatação do hiato, permitiu-se que o social assumisse pela primeira vez um lugar entre o sistema econômico e a ordem política, indicando a necessidade de se assumir um sistema de regulações nãomercantis. Diante desse contexto histórico, o social que qualifica a questão social torna-se o "lugar que as franjas mais dessocializadas dos trabalhadores podem ocupar na sociedade industrial" (p.31), e em resposta a ela, busca-se a sua integração social.

Para contextualizar a origem da questão social, onde os homens se organizam numa determinada sociedade e num contexto histórico dado, e que essa organização tem suas expressões na esfera de reprodução social, podemos afirmar, utilizando as palavras de Carvalho e Iamamoto que: 
A questão social não é senão as expressões do processo de formação e desenvolvimento da classe operária e de seu ingresso no cenário político da sociedade, exigindo seu reconhecimento como classe por parte do empresariado e do Estado. É a manifestação, no cotidiano da vida social, da contradição entre o proletariado e a burguesia, a qual passa a exigir outros tipos de intervenção mais além da caridade e repressão. (Carvalho \& Iamamoto, 1983, p.77)

Portanto, a questão social é uma categoria que expressa a contradição fundamental do modo capitalista de produção e esta contradição, está fundada na produção e apropriação da riqueza gerada socialmente os trabalhadores produzem a riqueza, os capitalistas se apropriam dela. É assim que o trabalhador não usufrui das riquezas por ele produzidas.

Para Iamamoto (2001), a emergência da referida categoria está vinculada ao surgimento da classe proletária e sua atuação no cenário político, por meio de suas lutas e reivindicações pelo reconhecimento dos seus direitos, por parte do bloco dominante principalmente pelo Estado. Já, segundo Pereira (2001a, p.54), estudiosa do tema, a questão social "não é sinônimo da contradição entre capital e trabalho, e entre forças produtivas e relações de produção - que geram desigualdades, pobreza, desemprego e necessidades sociais - mas, de embate político, determinado por essas contradições". Ou seja, os sujeitos históricos e conscientes do seu papel político devem explorar as contradições engendradas pelas mudanças estruturais no sentido de problematizar as desigualdades sociais, alterando a sua naturalização e lutando para que as questões sociais latentes sejam incorporadas na agenda política e nas arenas decisórias (Pereira, 2003).

Nesse contexto, é importante entender o papel do Estado como agente nos processos de desenvolvimento da questão social, considerando a sua inserção nas relações entre indivíduos, grupos e classes sociais. Ou seja, no momento em que a classe burguesa se instala no poder, o capitalismo se difunde e o trabalho assalariado já é organização dominante, o Estado passa a conceber o direito à assistência pelo trabalho.

Como toda categoria arrancada do real, nós não vemos a questão social, vemos as suas expressões, que acabam sendo formadoras da pobreza: o desemprego, o analfabetismo, a fome, a favela, a falta de leitos em hospitais, a violência, a inadimplência, etc. Assim é que, a questão social só se nos apresenta nas suas objetivações, em concretos que sintetizam as determinações prioritárias 
do capital sobre o trabalho, onde o objetivo é acumular capital e não garantir condições de vida para toda a população.

O surgimento da questão social no Brasil refere-se à generalização do trabalho livre (assalariado) numa sociedade em que a escravidão marca profundamente seu passado recente (Iamamoto, 1995). No período correspondente à Primeira República, (1890-1930), iniciou-se processo de industrialização e de implantação do modo de produção capitalista no País. Daí o aparecimento do operariado e da fração industrial da burguesia, o acirramento das contradições entre capital-trabalho e a explicitação da questão social (Wanderley, 2011).

Na Primeira República, onde o poder estava centralizado nas mãos da elite agrária, a questão social não era reconhecida como questão política legal e legítima. A resposta do Estado aos movimentos sociais e operários era realizada por meio da repressão policial ${ }^{26} \mathrm{e}$, do autoritarismo público e privado. A violência do Estado presente na trajetória das lutas do movimento operário foi o mais eficiente instrumento de manutenção da paz social necessária à acumulação capitalista.

Além do tratamento repressivo exercido no interior dos aparelhos do Estado, a questão social expressa nas más condições de habitação, de saúde, de trabalho, de higiene e de educação vivenciadas pelos trabalhadores foi objeto da atuação da Igreja Católica que, baseada nos princípios cristãos de humildade, solidariedade e amor ao próximo, teve nesses problemas amplo campo para o exercício da caridade e da filantropia. A filantropia também foi exercida pela classe dominante e estava associada ao prestígio social; seu posicionamento natural alternava entre a hostilidade e o apoio explícito à repressão policial e ações caridosas e assistencialistas (Iamamoto 1995).

O episódio mais importante no que se refere à Proteção Social, nas três primeiras décadas do século passado foi a promulgação da Lei Elói Chaves em 1923, que criou a Caixa de Aposentadoria e Pensão dos Ferroviários, que assegurava a essa categoria profissional direitos trabalhistas: aposentadoria por tempo de serviço, velhice ou invalidez; pensão em caso de falecimento e

\footnotetext{
${ }^{26} \mathrm{~A}$ questão social neste momento da nossa história era vista como questão de polícia, ou seja que exigia a repressão por meio do aparato do Estado, neste caso a Polícia, que era responsável pela ordem pública.
} 
subvenção de despesas funerais e assistência médica. A experiência pioneira dos ferroviários incentivou vários outros segmentos de trabalhadores organizados a construírem suas Caixas de Aposentadorias e Pensões (CAP), de atuação circunscrita ás empresas e geridas pelos próprios empresários e trabalhadores.

Em 1933 foi criado o Instituto de Aposentadoria e Pensão dos Marítimos (IAPM), que possibilitou não só a reunião sob o mesmo regime previdenciários dos membros da mesma categoria profissional, mas também a avocação pelo Estado de duas ordens problemas: o da acumulação e o da equidade (Santos, 1998, p.31). Ou seja, com a criação dos IAP, os benefícios relativos à CAP de cada categoria profissional foram unificados e o financiamento passou a ser tripartite, com a participação do Estado.

Observamos progressivamente a instauração e a promoção de direitos sociais assegurados pela posição que os indivíduos ocupam no mundo do trabalho regulamentado e, por conseguinte, não acessíveis universalmente, no que Wanderlei Guilherme dos Santos (1974, p.74) chama de cidadania regulada:

[...] o conceito chave que permite entender a política econômico-social pós-30, assim como a passagem da esfera da acumulação para a esfera da equidade, é o conceito de cidadania, implícito na prática política do governo revolucionário, e que tal conceito poderia ser descrito como o de cidadania regulada. Por cidadania regulada entendo o conceito de cidadania cujas raízes encontram-se, não em um código de valores políticos, mas em um sistema de estratificação ocupacional, e que, ademais, tal sistema de estratificação ocupacional é definido por norma legal. (Santos, 1974, p.74)

Ou seja, a cidadania é limitada por fatores políticos (Carvalho, 2002, p. 115). Essa associação entre cidadania e ocupação, ainda segundo o referido autor, proporcionou as condições para que se formasse, depois, os conceitos de mercado de trabalho informal e marginalidade, isso porque, no primeiro conceito, não estavam instalados os desempregados, ou subempregados ${ }^{27}$, mas todos que por mais regulares e estáveis que estivessem não tinham suas ocupações regulamentadas pelo Estado. As posturas de política social eram concebidas como privilégio e não como direito, já que uma série de trabalhadores (todos os

\footnotetext{
${ }^{27}$ Entendidos aqui, como aqueles que exerciam trabalhos informais.
} 
autônomos e, principalmente, as trabalhadoras domésticas), ficava à margem dos benefícios concedidos pelo sistema previdenciário da época.

Em 1940, dando continuidade à proposta trabalhista de Getúlio Vargas, foi regulamentado o salário mínimo, que já contava com sua previsão legal nas Constituições de 1934 e 1937. Ainda durante o Governo de Vargas, em 1943, foi criada a Consolidação das Leis do Trabalho (CLT).

Foi também em 1942 que, o governo de Vargas, buscando legitimidade junto à população pobre criou a Legião Brasileira de Assistência (LBA), com o objetivo de inicialmente atender às famílias dos pracinhas que foram para a guerra, e logo depois, o trabalho estendeu-se a população pobre, especialmente com programas na área materno-infantil. A LBA era coordenada pela primeira dama Darcy Vargas e representou o braço assistencialista do governo. "Esse traço clientelista e vinculado à benemerência apresentou-se persistente por muitos anos na política assistencial brasileira" (Couto, 2010, p.103).

No período entre 1945 e 1964, o Brasil viveu a fase de democracia populista. Segundo Malloy (1987), isso representou uma mudança formal no sistema representativo, contudo, no que se refere à construção do Sistema de Proteção Social brasileiro, não foram observadas mudanças significativas. Embora o Brasil tenha adotado um regime democrático após 1945, muitas das estruturas corporativas instituídas nos anos precedentes permaneceram intactas, especialmente no campo das relações de trabalho, como foi o caso do sistema de previdência social.

Os governos militares iniciados em 1964 inauguraram a fase de consolidação do sistema, acompanhados por profundas mudanças na estrutura institucional e financeira das políticas. No período entre meados da década de 1960 e 1970, são implementadas políticas de cobertura relativamente ampla, por meio de organização de sistemas nacionais públicos ou estatalmente regulados de provisão de serviços sociais básicos. De acordo com Draibe (1990), esse período foi marcado pela consolidação do sistema de proteção social; pela organização dos sistemas nacionais públicos ou estatalmente regulados na área de bens e serviços sociais básicos, apresentando tendências universalizantes e políticas de massa; e pela cobertura relativamente ampla, distinguindo-se e ultrapassando a forma fragmentada e seletiva do período anterior. 
Nesse período, foram efetuadas, no âmbito da política social previdenciária, ações de integralidade tecno política de áreas a ela relacionadas: em 1966, cria-se o Instituto Nacional de Previdência Social (INPS); outra inovação foi a introdução do sistema de formação do patrimônio do trabalhador e da chamada participação nos lucros da empresa por meio da implementação do FGTS Fundo de Garantia por Tempo de Serviço); PIS (Programa de Integração Social) e PASEP (Programa de Formação do Patrimônio do Servidor Público).Ainda nos anos seguintes a previdência passou a ter cobertura para aqueles que haviam sido excluídos anteriormente como os empregados domésticos (1972), autônomos (1973) e trabalhadores rurais e seus dependentes (1976). Em síntese, "a previdência passou a abranger a totalidade das pessoas que exerciam atividades remuneradas no país" (Oliveira, et al., 1997, p. 8). Em 1974 foi criado o Ministério de Previdência e Assistência Social e em 1977 foi criado o Sistema Nacional de Previdência e Assistência Social (SINPAS).

Ressalte-se, ainda, o estabelecimento, como benefício previdenciário, da Renda Mensal Vitalícia, em 1974, que consistia em um benefício mensal no valor de meio salário mínimo, dirigido aos trabalhadores com mais de 70 anos de idade que não dispusessem de meios de subsistência e que tivessem contribuído, pelo menos, por doze meses. Tal benefício é considerado como a primeira iniciativa de programa de transferência de renda no Brasil.

Esse quadro persistiu durante todo o regime ditatorial. A partir da segunda metade dos anos 1970, iniciou-se o processo de luta pela democratização política, que adquiriu novas características e estratégias. Antes circunscrita às universidades, aos partidos clandestinos e aos movimentos sociais, ela vai sendo transportada para o interior do próprio Estado. Na segunda metade dos anos 1980, presencia-se o surgimento de um novo processo de luta entre as classes, representado pela ação política de frações da burguesia e das classes trabalhadoras, por meio dos sindicatos, dos partidos e outros movimentos organizativos, incitando uma redefinição das práticas sociopolíticas das classes (Mota, 1995).

A década de 1980 apresentou um país com grandes dificuldades produzidas pela concentração de renda e por uma política econômica restritiva no que concerne à participação da população na riqueza nacional, que já não indicava 
o crescimento do bolo como estratégia de acumulação de riqueza apresentada pelos governos ditatoriais, muito menos propunha a sua distribuição, denotando ser uma sociedade extremamente desigual (Couto, 2004). De acordo com Draibe (1990), nessa época o Brasil chegou a investir na área social quase como um país desenvolvido (18,3\% do PIB), entretanto mostraram resultados (pobreza e miséria) tão desanimadores quantos os do mundo subdesenvolvido

Tal processo de redemocratização do país desencadeou novas mudanças no âmbito das políticas de proteção social, institucionalizadas com a Constituição de 1988, que declarou direitos resultantes agora da participação popular, tão incomum nas outras Constituições, além de estabelecer um novo papel interventor do Estado no campo das políticas sociais, cujo maior avanço foi a adoção do conceito de seguridade social, reunindo as áreas de saúde, da previdência e de assistência social em busca da universalização da cidadania.

A partir da Constituição Federal de 1988 passa a configurar no Brasil um novo cenário de proteção social, bem como a presença de dispositivos constitucionais prevendo a responsabilização dos entes federados para a erradicação da pobreza, conforme veremos mais adiante.

\section{2. \\ O cenário da proteção social: algumas considerações importantes}

Os sistemas de proteção social sempre existiram nas sociedades humanas, com vários estudos nas áreas de história, antropologia, sociologia, dentre outras, que comprovam a existência da solidariedade social nas sociedades mais tradicionais, modernas e contemporâneas.

O autor Di Giovanni (1998) afirma que as sociedades sempre alocaram recursos e esforços em suas atividades de proteção social, que podem variar de acordo com os critérios históricos e culturais e podendo ser classificadas em: tradicional (referente à caridade, fraternidade e solidariedade); da troca ( conjunto de práticas econômicas, que podem ser face a face ou relacionadas ao mercado) e; 
da autoridade ou da políticas (presença do estado como gestor, regulador e protetor das relações sociais).

Esta classificação não tem o caráter evolucionista, visto que as três formas de proteção citadas pelo autor perduram no contexto atual, assim como coexistem. Porém, na contemporaneidade há a predominância das formas de proteção social exercidas pelo estado, alocadas politicamente.

A intervenção do Estado, com a formação de ações sociais não mercantis tem origem nas sociedades tradicionais para impedir ou diminuir o impacto de determinados riscos sobre indivíduos e grupos sociais. As primeiras populações, que foram objeto de intervenção social do Estado de acordo com Castel (1998), foram aquelas identificadas como não capacitadas ao exercício do trabalho como órfãos, mulheres com filhos pequenos, inválidos, idosos e indigentes, ou seja, populações submetidas a grandes situações de vulnerabilidades e isentas da obrigação do trabalho, que se constituíram no público legítimo para os recursos e serviços públicos.

Porém, a consolidação dos Sistemas de Proteção Social não ocorreu no âmbito das situações de incapacidade e independência, "passando a exercer papel central e estratégico nas sociedades modernas" (Jaccoub, 2010, p.104) e sim em torno do conceito de risco social que a intervenção pública passou a ser construída, por meio da observação das transformações ocorridas no mundo trabalho e as vulnerabilidades a ele associadas, cuja reponsabilidade até então era da esfera privada e estava centrada na proteção do trabalhador.

Os riscos sociais podem ser compreendidos como aqueles relacionados a fatores que podem incidir sobre grupos ou indivíduos, tais como: doença, velhice, infância, invalidez, etc. E embora estivessem associados a condições naturais e/ou ambientais, são oriundos, quase sempre de fatores políticos, sociais ou culturais (Viana \& Levcovitz, 2005).

Com o crescimento da industrialização, no final do século XIX, percebe-se a pobreza como problema efetivo das sociedades, com centralidade no debate sobre a proteção social. A condição do trabalhador assalariado e os fenômenos da limitação ao trabalho passam a ser vistos como parte presente e pertencente da vida social e laboral, assim como regulares e cotidianas. 
Na segunda metade do século XX, temos a mudança na organização dos sistemas de proteção social, especialmente nos países desenvolvidos, que passam a ter centralidade nos trabalhadores e nos cidadãos. Observamos, nesse contexto, a emergência dos programas não contributivos de garantia de renda, ao lado da rápida expansão dos serviços sociais de acesso universal, instaurando um novo modelo de intervenção do Estado.

Os benefícios sociais passaram a ser garantidos nas demandas para a melhoria das condições sociais de grupos vulneráveis e de garantias de bem estar associadas à cidadania. Esping-Andersen (1990) cita a Alemanha, a Inglaterra e a Suécia dentre outros países, em seus estudos, como países que instituíram seguro universal, baseados em contribuições não contributivas ou em contribuições uniformes, garantindo benefícios iguais, visando assegurar um mínimo vital a todos os cidadãos, destacando-se os países conhecidos como o modelo beveridgiano $^{28}$. Nestes casos, houve a ampliação dos gastos sociais por parte do Estado, em contrapartida com o aumento da universalização dos serviços de saúde, creches e cuidados a pessoas idosas ampliados, bem como a expansão dos programas de garantia de renda não contributivos para a infância e a habitação.

Porém, nas décadas de 1980 e 1990, com as alterações no cenário do mundo do trabalho e o acirramento da competitividade das economias no mercado internacional, a trajetória da expansão dos Estados Sociais ou "Welfare States" passou a ser colocada sobre forte crítica: excessiva expansão dos direitos sociais e excessiva participação do Estado e do gasto público ${ }^{29}$ no campo social. Questionava-se também neste momento, o papel dos governos no campo da proteção social, caracterizando os mesmos como desnecessários e mesmo ineficientes.

Neste contexto de acordo com Jaccoub (2010) a proteção contra os riscos deveria ser responsabilidade prioritária dos indivíduos e objeto da ação do mercado, pelos regimes capitalizados e geridos pelo mercado, ou da própria

\footnotetext{
${ }^{28} \mathrm{O}$ economista e reformista social britânicoWilliam Henry Beveridge (1879-1963) elaborou em 1942 o Report on Social Insurance and Allied Services, famoso Plano Beveridge, visando libertar o homem da necessidade. Propôs, assim, que todas as pessoas em idade de trabalhar deveriam pagar uma contribuição semanal ao Estado. Esse dinheiro seria posteriormente usado como subsídio para doentes, desempregados, reformados e viúvas. Os subsídios deveriam então tornar-se um direito dos cidadãos, em troca de contribuições, em vez de pensões dadas pelo Estado.

${ }^{29}$ Compreendia-se que este gasto deveria ser responsabilidade das empresas.
} 
sociedade por meio dos movimentos voluntários. "Nesta nova interpretação, a pobreza se destaca como um fenômeno social específico, legitimador da ação do Estado" (Jaccoub, 2010, p. 107).

Quando o debate sobre a temática recai sobre os países em desenvolvimento, o Banco Mundial (2001) por meios de seus relatórios, centraliza o debate conceitual no combate à pobreza indicando que os pobres deveriam estar inseridos em estratégias governamentais com o envolvimento do setor público e privado, visando o fortalecimento das suas capacidades e objetivando a prevenção de acontecimentos aleatórios (gestão de riscos). Já com relação aos extremamente pobres, o Estado é incapaz de mobilizar estratégias individuais de proteção social, onde somente seriam cabíveis as políticas de transferência de renda.

Outro conceito importante relacionado à proteção social e muito utilizado atualmente, baseou-se na discussão efetuada pela Comissão de Estudos para a América Latina-CEPAL, enfatizando a necessidade da proteção social estar baseada na perspectiva dos direitos sociais, em função do mercado de trabalho, que há muito tempo na América Latina e Caribe vem sofrendo grandes mudanças por causa da precarização, flexibilização e desemprego estrutural, e não vem mostrando com isso, a capacidade abrangente de proteger a parcela significativa da população dos riscos relacionados à falta de renda, saúde e envelhecimento.

A ideia defendida pela CEPAL consiste na adoção de um sistema de transferência que se propõem a oferecer proteção contra os riscos sociais, combinando mecanismos contributivos e não contributivos (auxílios financeiros dos programas assistenciais por meios das transferências diretas de renda) e transferências de bens e serviços (como por exemplo, os serviços universais de saúde).

A adoção de um sistema de transferência também é defendida por Draibe (2005), porém a partir de uma perspectiva que preconiza apenas o mecanismo não contributivo. De acordo com a autora, o sistema precisa combinar transferências diretas de renda não contributivas com as transferências de bens e serviços sociais, sobretudo paras as famílias brasileiras que estão abaixo da linha de pobreza, que além da insuficiência de renda, quase sempre não têm as suas necessidades vitais satisfeitas, ou seja, não tem acesso à escola pública de qualidade, á saúde pública de qualidade. 
É nesse contexto que o Estado passa a ser responsável prioritário pela garantia dos direitos sociais e da proteção social, por meio da execução das políticas públicas, cuja materialização são os programas, planos e ações. Nesse cenário tem destaque, em vários países, especialmente no Brasil, a implantação de Programas de Transferência de Renda com Condicionalidades como principal forma de garanti de proteção social às populações mais vulneráveis.

O desenvolvimento de políticas sociais com o objetivo de proteger os pobres é antigo, existindo desde as sociedades pré-capitalistas e, precede o surgimento de dois movimentos que são o fundamento da questão social, surgida no século XX: a economia de mercado e a reação da classe trabalhadora aos efeitos perversos dessa economia de mercado (Pereira, 2000).

Este movimento, tenso e contraditório entre os interesses do capital e do trabalho, advém dos modelos dos Estados de Bem Estar ou os Welfare State, que são os sistemas de bem estar dos Estados capitalistas desenvolvidos, como os Estados Unidos, Alemanha, França Itália, Suécia, dentre outros e, com caraterísticas próprias e peculiaridades em cada país onde foi implantado.

Neste modelo, exitoso entre as décadas de 1950 e 1970, foi nos Estados de Bem Estar europeus que o Estado atuava de acordo com as orientações intervencionistas keynesianas, procurando compensar as deficiências de alocação feitas pelo mercado com a implantação das políticas sociais.

Quanto a sua tipologia, para os fins a que se propõe este estudo, cabe-nos utilizar a literatura proposta por Esping-Andersen (1991,1995), que classificava os Estados de Bem Estar em três regimes: social democrata (institucional/redistributivista); conservador/corporativista (meritocrático particularista) e o modelo residual ou liberal.

O primeiro modelo caracteriza-se por um sistema de proteção social mais abrangente, com cobertura universal e benefícios garantidos como direitos, cujo valor é desvinculado da contribuição por parte do beneficiário. É normalmente identificado como modelo inglês de proteção social, formulado por Beveridge. Como exemplo destes podemos citar os países do norte da Europa, especialmente os escandinavos. 
O segundo modelo é o conservador/corporativista ou meritocrático/particularista, que vincula o emprego ao acesso a benefícios. É também conhecido como o modelo "alemão" ou modelo de seguro, baseado em Bismarck. Adota como modelo a previdência estatal ou compulsória. Inclui países como Áustria, Alemanha, França, Japão, Bélgica e Itália.

O terceiro modelo, residual ou liberal, para a execução das suas políticas utiliza testes de meio para eleger os beneficiários. O mercado e a família são os dois mecanismos naturais pelos quais os indivíduos devem suprir as suas necessidades. As políticas sociais do Estado só entram em cena quando estes dois mecanismos forem incapazes de garantir, minimamente a subsistência dos indivíduos. Os direitos dos beneficiários não estão ligados ao seu desempenho no trabalho, mas sim às suas necessidades sobrevivência (Esping-Andersen, 1985). Este modelo é peculiar nos países de tradição anglo-saxônica como Estados Unidos, Austrália, Canadá, Suíça e Grã-Bretanha.

Apesar das diversas diferenças entre os três modelos de Estado de Bem Estar, eles se pautavam por algumas orientações comuns, dentre as quais podemos citar:

a) Garantia de certo nível (menor ou maior, de acordo com a sua configuração) de proteção aos indivíduos frente ao modelo de mercado capitalista, especialmente no que se refere às consequências destes para as classes dos mais baixos extratos sociais e aqueles incapacitados para o trabalho;

b) A partir da implantação das políticas públicas, determinados direitos são assegurados pelo Estado, objetivando a promoção da cidadania ${ }^{30}$.

c) As políticas representam ou tendem a ter caráter redistributivo, necessitando de significativas receitas fiscais e contribuições sociais.

A partir da conceituação e da tipificação dos Estados de Bem Estar, a proteção social, que desde os meados do século XX engloba seguridade social,

\footnotetext{
30 Usaremos como definição de cidadania a conceituação proposta por Amartya Sem (2000), que afirma que o desenvolvimento de um país está essencialmente ligado às oportunidades que ele oferece à população de fazer escolhas e exercer sua cidadania. E isso inclui não apenas a garantia dos direitos sociais básicos, como saúde e educação, como também segurança, liberdade, habitação e cultura. Ou seja, a cidadania está diretamente ligada ás oportunidades e a possibilidade de escolhas.
} 
poder ser definida como as garantias a essa seguridade, bem como políticas sociais. É um conjunto de iniciativas públicas ou reguladas pelo Estado, para a provisão de serviços e benefícios sociais, visando enfrentar situações de risco social ou privações sociais. (Pereira-Pereira, 2000, p.16).

No Brasil, a formação de um Estado de Bem Estar, desde os seus primórdios, na década de 1920, até a regulamentação complementar no pós Constituição Federal de 1988, foi e é um processo repleto de tensões e contradições.

Segundo os estudos de Draibe (1988 e 1993a), o modelo de Estado de Bem Estar no Brasil de acordo com a tipificação proposta por Esping-Andersen (1991 e 1995), é do tipo meritocrático/particularista, partindo da premissa de que "as pessoas devem ter condições de resolver as suas próprias necessidades com base em seu trabalho, em seu mérito, em seu desempenho profissional e na sua produtividade" (Draibe, 1993, p.28).

Ainda, de acordo com Draibe (1988, p.34), o Welfare State no Brasil teve forte tendência a adquirir, nas suas relações com grupos de interesse e com o sistema político conotação corporativista, mas foi o caráter clientelista que mais marcou a sua dinâmica, especialmente em função da condição de pobreza que sempre atingiu um contingente considerável da população brasileira.

\section{3.}

Interlocuções sobre pobreza: concepções e mensuração da categorias

Para compreender categoria pobreza é necessário efetuar uma conceituação que atenda aos objetivos do presente estudo. Para isso, elegemos a concepção de Carneiro (2005), que conceitua pobreza sob quatro aspectos:

(a) Monetária - relacionada ao aspecto da renda, considerando pobre aquele que obtiver renda até um determinado valor;

(b) Necessidades básicas insatisfeitas - mais amplo do que o de renda monetária, mas ainda se limita a dimensão econômica de pobreza; 
(c) Privação de capacidades - centra a discussão em outro patamar, considerando a pobreza como a carência ou privação de capacidades que permitam às pessoas viver com uma vida digna. Este aspecto contempla dimensões menos tangíveis como: auto respeito, autonomia, dignidade, senso de liberdade;

(d) Pobreza crônica - trata-se da pobreza ao longo do tempo, especialmente no seu contexto intergeracional, envolvendo fatores econômicos e sócios culturais.

Portanto, parte-se de um conceito tendo a pobreza com referência multidimensional, requerendo assim para o seu enfrentamento estratégias multisetoriais. E, para além do seu enfrentamento é necessário compreender o caráter histórico da pobreza e suas implicações na formação econômica e social do país.

É importante destacar que no Brasil a pobreza sempre surpreendeu tanto por sua intensidade, mas, sobretudo por sua estabilidade. E esta pobreza acaba gerando um cenário de profundas desigualdades que se mantém inerte e resiste a mudanças estruturais e conjunturais das últimas décadas. Mesmo com diversas tentativas via planos econômicos, não foi possível reduzir a pobreza, especialmente a extrema.

A estratégia adotada pelos governos para a redução da pobreza e o combate à desigualdade reside no crescimento da renda per capita ou a distribuição mais igualitária de renda, além da combinação de políticas que estimulem o crescimento econômico e diminuam ao mesmo tempo, a desigualdade, que tem dentre uma de suas causas, a pobreza. Em princípio, estas estratégias aparentam ser mais eficazes e velozes no combate à pobreza e, por tal motivo, foram adotas pelo governo brasileiro, na última década.

Para a compreensão da materialização da categoria pobreza no Brasil é necessário tecer um diagnóstico básico referente à estrutura de pobreza no país, que de acordo com Paes de Barros (2001, p.23)

No limiar do século XXI, o Brasil não é um país pobre, mas um pais extremamente injusto e desigual com muitos pobres. A desigualdade encontra-se na origem a pobreza e combate-la torna-se um imperativo. Imperativo de um 
projeto de sociedade que deve enfrentar o desafio de combinar democracia com eficiência econômica e justiça social. Desafio clássico da era moderna, mas que toma contornos de urgência no Brasil contemporâneo.

Observa-se que o cenário brasileiro, de acordo os dados apresentados anteriormente, é de profunda desigualdade gerada pela pobreza e vice versa. Ou seja, há um número expressivo do contingente populacional que acaba vivendo com uma renda per capita inferior aos patamares mínimos estabelecidos. Em contrapartida, no pólo oposto há um pequeno número de pessoas vivendo numa situação riqueza plena.

A desigualdade de renda e a desigualdade de riqueza acabam sendo muito presentes na sociedade brasileira, ocasionadas pela via da concentração de renda. Esta situação permanece solidificada e imutável ao longo do tempo em função do processo de concentração de renda que vem se perpetuando no país.

No Brasil, a pobreza e a desigualdade somente serão de fato combatidas no momento em que o Estado implementar as políticas públicas, além das reformas e ajustes capazes de romper com o ciclo vicioso da concentração de renda. Sabe-se também que o capitalismo implantado é gerador de desigualdades, sendo necessária a atuação do Estado para as redução das desigualdades, assim como o enfrentamento da pobreza.

Por isso, a etapa atual do capitalismo requer um debate sobre o papel do Estado, a promoção de justiça social e a convergência das políticas sociais públicas para as reais necessidades da sociedade, com vistas ao desenvolvimento socioeconômico sustentável, por meio de elaboração de estratégias de proteção social objetivando a redução da pobreza e das desigualdades, ou seja, o combate das múltiplas expressões da questão social e a concentração de renda, como é o caso do Brasil.

A fim de compreender os enfoques sobre pobreza dos quais estamos discutindo, faremos a seguir um detalhamento dos mesmos, bem como as suas formas de mensuração. 


\subsection{1. Enfoque Monetário: a renda como fator preponderante}

É o enfoque dominante na produção científica, que aborda a pobreza a partir da perspectiva monetária, focalizando a renda e o consumo dos indivíduos e domicílios como informação básica tanto para a concepção quanto para a mensuração da pobreza. Serão pobres portanto, aqueles que não conseguirem aqueles que não conseguirem renda suficiente para satisfazer as necessidade básica, abosultas ou relativas, de sobrevivência.

Os pioneiros no estudo da mensuração da pobreza são os pesquisadores Charles Booth e Seebhom Rowntree, ao realizarem pesquisa sobre a quantificação e análise do tema no final do século XIX, com questões mais técnicas do que analíticas, ou seja, a definição de pobreza é dada por sua mensuração: pobreza está ligada diretamente à ausência de renda, sendo pobres os que se situam abaixo de uma linha de rendimento monetário definida de forma absoluta ou relativa.

Booth e Rowntree partilhavam da concepção de pobreza como algo extremamente perceptível, sendo que os dados obtidos eram objetivos e a partir dessa objetividade a ciência poderia propor ações efetivas para a redução da pobreza, sem considerer aspectos ou dimensões subjetivas. Os dois percebiam a pobreza sob uma perspectiva individualista, sem percebê-la como resultado dos processos sociais.

Apesar dos dois partilharem de um conjunto importante de pressupostos e orientações, Booth incluia uma perspectiva qualitativa, definindo a pobreza a partir da visão de agentes locais, localizando-a de forma catográfica e espacial, de maneira semelhante ao que se faz hoje. Já Rowntree focalizou nas medidas estatisticas, com extensas coletas de dados objetivando estabelecer a distinção entre pobres e não pobres, sendo esta a perspectiva que dominou nos campos de estudos, especialmente de economia. Esses estudos seminais, desenvolvidos no final do século XIX, ainda inspiram, de forma dominantes, os estudos realizados sobre pobreza no século XIX. 
Outra concepção sobre pobreza monetária é de vertente nutricionista e considera pobreza sob o ponto de vista de padrões de subsistência mínimos no âmbito da subsistência ou da sobrevivência (Lavinas, 2003, p. 29-30).

Cabe destacar que a abordagem econômica utiliza uma variável monetária, basicamente a renda, com a conotação de medida de pobreza. A partir da visão de pobreza como fenômeno exclusivamente econômico, mede-se o nível de da qualidade de vida tendo como referência uma linha de pobreza. Uma pessoa é pobre, extremamente pobre ou indigente se a sua renda for determinado valor, o que vai definir também o seu potencial de consumo.

É o enfoque mais utilizado pelo poder público e para o estabelecimento dos valores de transferência de renda por grande parte das políticas de proteção social em curso, conforme podemos observar no caso do Programa Bolsa Família no Brasil. Apesar da sua larga utilização, esta concepção possui fragilidades e limitações.

Uma das principais fragilidades consiste na impossibilidade de definir de forma conclusiva abaixo do qual o indivíduo está ameaçado na sua sobrevivência, ou seja, existe um nível e este é ponto de demarcação, sempre relativo, fruto de uma convenção. Além disso, há a fragilidade da universalidade do valor da renda, dada a realidade diversa de tempo, lugares, condições de vida e de indivíduos diferenciadas, de acordo com as características do território onde vive.

A tecnologia e o avanço das estatisticas tem contribuido para incorporar outras variáveis no enfoque monetário, como por exemplo o tempo. Porém, a unidimensionalidade da perspectiva não se altera. Nesse enfoque, não se estabelece conexões entre a renda e as outras dimensões da vida das pessoas, como se essas não existissem ou não importassem para o compreender o problema da pobreza e as formas para a sua superação.

Outro aspecto importante a ser destacado é a mensuração da pobreza com enfoque monetário é efetuada a partir do estabelecimento das linhas de pobreza e indigência. A primeira é estimada tendo como base o custo de uma cesta de alimentos que cubra as necessidades nutricionais da população, agregando a esse valor os recursos necessários para satisfazer as necessidades básicas não alimentícias. Como itens não alimentares temos por exemplo, habitação, 
vestuário, saúde e cuidados pessoais, transporte e comunicação, artigos da residência, entre outros (Rocha, 2003, p.63). A linha de pobreza é a soma dos valores calculados para a cesta alimentar e para as demais despesas básicas não alimentares. A linha de indigência, por sua vez, refere-se ao custo de cesta alimentar minima, sem considerar as demais necessidades. Os indigentes são desta forma um subconjunto dos pobres. Tem-se com essas duas linhas a definição do conceito de pobreza absoluta.

Outro conceito importante refere-se a pobreza absoluta e pobreza relativa, de acordo com Rocha (2006, p.11 e p.12). A pobreza absoluta está ligada as condições de sobrevivência física, portanto, ao não atendimento das necessidades vinculadas ao mínimo vital. Já o conceito de pobreza relativa agrega uma medida de desigualdade, para indicar que a pobreza se define em termos de carências materiais expressas por meios monetários, mas também que as necessidades são determinadas culturalmente por parâmetros do que uma sociedade considera como mínimo de vida aceitável. Ou seja, identifica as pessoas que tenham um nível de vida baixo em relação a sociedade em que vivem, sendo definida a partir de um valor considerado como mínimo na sociedade em questão, definido mais ou menos arbitrariamente. Essa perspectiva ganha corpo a partir da década de 1970, considerando a pobreza como um padrão médio.

A principal vantagem do uso de enfoques baseados na renda consiste na possibilidade de se identificar, sem muitos problemas o universo alvo de intervenção. Uma vez estabelecidos os parâmetros para as linhas de demarcação entre pobres e não pobres, simplica-se o processo de indentificação de pobres, não pobres e indigentes.

\subsection{2. \\ Necessidades básicas Insatisfeitas: o enfoque na noção das privações}

Na América Latina a perspectiva das necessidades básicas ganha destaque nos anos de 1970 e 1980, centrada na identificação de déficits e níveis de carência que condicionam a pobreza. Sustenta que pobres são as pessoas que não tem as 
suas necessidades básicas satisfeitas, cujo consumo de bens e serviços não atinge o mínimo necessário (Lavinas, 2003, p.32). As variáveis identificadas não são estabelecidas e nem estão hierarquicamente distribuídas, mas atingem uma grande gama de possibilidades: saúde, educação, assistência social, habitação, segurança, saneamento básico, etc., além das variáveis relacionadas ao processos de natureza psico-social tais como participação, auto estima, autonomia, capacidades, etc..

O enfoque nas necessidades insere de forma clara a relatividade presente na caracterização e na mensuração da pobreza, visto que as necessidades são diferentes em cada, cada lugar, bem como inerentes a cada indivíduo e a cada grupo social.

Apesar de diferenças e porque não podemos dizer, avanços, no que se refere a um comparativo com o enfoque monetário, ainda prioriza as dimensões materiais da pobreza e estabelece um limiar entre pobres e não pobres sob a ótica dos mínimos sociais (Pereira, 2001).

Apesar de abandonar a renda como medida e pobreza e focalizar resultados efetivos em termos de condições e qualidade de vida, incorporando uma perspectiva multidimensional da pobreza apontando a inter relação entre as diversas carências, tem uma utilidade limitada para orientar o conteúdo dos programas antipobreza, uma vez que não situa as conexões entre fatores condicionantes da pobreza e sobre sua reprodução (Bronzo, 2005, p. 42).

Para mensurar a pobreza por meio do enfoque das necessidades básicas são operacionalizadas os conceitos através de variáveis relacionadas às condições de residência, aglomeração dos domicílios, disponibilidades dos serviços (água potável, eletricidades, serviços sanitários) acesso à escola, capacidade econômica do chefe da família, dentre outras. Esse enfoque ao estabelecer os graus mínimos de satisfação de necessidades básicas, define-se linha de pobreza a partir da noção de mínimos sociais.

Uma das desvantagens do método é que não é possível hierarquizar as necessidades, atribuindo pesos diferentes para cada uma delas. Além disso é preciso considerar o contexto familiar, local, temporal bem como as necessidades pessoais e dos individuais não sendo assim possível estabelecer pesos para cada necessidade. 


\subsection{3. \\ Enfoque nas capacidades: ampliando horizontes}

A partir das críticas nos enfoques de renda e das necessidades básicas nos anos de 1980 e, diante de novas metodologias e de bases de dados que ganham força, surgem novos enfoques sobre pobreza a fim de criar novos horizontes para o debate sobre o tema.

O foco no conceito de capacidades, elaborado por Amartya $\operatorname{Sen}^{31}$ a partir das críticas ao enfoque do utilitarismo e as concepções de bem estar daí derivadas. Após as suas formulações tem-se a expansão dos enfoques para além da renda e da utilidade. O movimento de expansão conceitual da concepção de Sen tem ocorrido tanto em países desenvolvidos como em países em desenvolvimento.

Na perspectiva de Sen, pobreza é definida como carência ou privação de capacidades, sendo pobres aqueles que carecem de capacidades básicas para operarem no meio social e aqueles que carecem de oportunidades para alcançar níveis minimamente aceitáveis de realizações, o que pode independer da renda que os indivíduos possuem (Sen, 2000).

Sen faz críticas aos fundamentos éticos do utilitarismo ${ }^{32}$, rejeitando-o como medida de bem estar e maximização da utilidade como suposição comportamental. Para o autor, o bem estar é visto em relação a realização do potencial humano, entendido como a liberdade dos indivíduos viverem a vida que valorizam. $\mathrm{O}$ enfoque não é mais a renda, sendo que os recursos monetários são meios para adquirir o bem estar e o bem estar em si (Sen, 2000, p.14).

Esse enfoque incorpora de forma plena as diferenças entre indivíduos: saúde, idade, condição física e contexto social, dentre outras que implicam diferentes necessidades, fazendo com que algumas pessoas precisem de mais recursos para obter as mesmas realizações.

${ }^{31}$ Utilizamos Amartya Sem porque a concepção de pobreza do autor vem ao encontro de uma abordagem atualmente largamente utilizadas nos estuados sobre pobreza, bem como atende as perspectivas de pobreza aqui discutidas, no âmbito do Plano Rio Sem Miséria.

${ }^{32} \mathrm{O}$ utilitarismo é uma doutrina ética defendida principalmente por Jeremy Bentham e John Stuart Mill que afirma que as ações são boas quando tendem a promover a felicidade e más quando tendem a promover o oposto da felicidade. Filosoficamente, pode-se resumir a doutrina utilitarista pela frase: Agir sempre de forma a produzir a maior quantidade de bem-estar (Princípio do bemestar máximo). 
Segundo Sem, a renda permite a realização de uma capacidade, mas o central é a capacidade e não a renda. Esta é apenas um meio e o não fim, sendo que os objetivos de uma boa vinda incluem uma vida longa, saudável e criativa, desfrutando um nível de vida descente com liberdade, dignidade, auto estima e respeito. O eixo do enfoque é a ampliação das oportunidades, da expansão das capacidades (capability ${ }^{33}$ ) básicas para que as pessoas possam levar uma vida digna.

Com o enfoque nas capacidades, tem-se a expansão da visão de pobreza para além das dimensões materiais, permanecendo o enfoque nos indivíduos e na perspectiva que permita aos indivíduos o exercício da liberdade. A dificuldade em operacionalizar de forma adequada a concepção de capacidades está na capacidade se ser e fazer algo, podendo ser considerada esta como uma das suas limitações.

$\mathrm{O}$ enfoque nas capacidades encontra mais dificuldades para a sua operacionalização. A definição do que sejam necessidade básicas e o grau de realização dessas capacidades é uma questão central e, não existe nesse enfoque, de forma explícita uma lista de necessidades, para deixar em aberto tais especificações para serem definidas de acordo com as normas societárias das diferentes culturas. O desafio está portanto, em operacionalizar o conceito de capacidades em algo mensurável.

Observa-se portanto que este enfoque diverge das visões anteriores nos seus aspectos conceituais bem como na sua mensuração. Por isso, a importância de tecermos considerações, ainda que breves, sobre as diferentes abordagens de pobreza, que serão utilizadas na análise do Plano Rio Sem Miséria, dada a premissa da qual parte o Plano, ou seja, de que pobreza é multidimensional e que o seu enfrentamento é multisetorial.

Após esta contextualização, passaremos a tratar dos antecedentes do Plano do estado do Rio de Janeiro, e que se configuram como políticas de enfrentamento á pobreza e ao mesmo tempo, de proteção social, no Brasil.

\footnotetext{
${ }^{33}$ The capability approach (also referred to as the capabilities approach) is an economic theory conceived in the 1980s as an approach to welfare economics. In this approach, Amartya Sen brings together a range of ideas that were hitherto excluded from (or inadequately formulated in) traditional approaches to the economics of welfare. The core focus of the capability approach is on what individuals are able to do (i.e., capable of)
} 


\section{3 \\ Antecedentes do Plano Rio Sem Miséria}

\section{1. Constituição Federal de 1988 e os avanços das políticas sociais no Brasil}

A discriminação efetuada pelo Estado, que definia os cidadãos com direito de acesso à proteção social perdurou até a Constituição Federal de 1988. Com as mudanças trazidas, a nova Carta pode ser entendida como um marco de garantia de direitos da construção de uma rede de proteção social para todos os cidadãos e não somente para aqueles que estavam inseridos no mercado formal de trabalho, pois elegeu um conjunto de valores éticos considerados fundamentais para a vida nacional, configurando assim no Brasil um modelo de Estado de Bem Estar ${ }^{34}$ próximo aos dos países europeus.

O cenário presente no país por ocasião da promulgação da Constituição materializa o processo de redemocratização vivido no país após mais de 20 anos de ditadura militar, e representa o resultado de uma conjuntura de discussão e de mobilização política. Dentre seus conteúdos mais expressivos, merecem destaque: o forte componente de garantia de direitos de cidadania e de correspondente responsabilização do Estado; de afirmação do compromisso com a democracia direta, por meio da institucionalização de canais de participação da população no controle da gestão pública; e, ainda, de construção de um novo pacto federativo, com ênfase na descentralização e no fortalecimento dos municípios.

Já no campo das políticas públicas, garante o direito universal (independentemente de qualquer pagamento direto ou indireto) à saúde e à educação e, ainda, define que a Seguridade Social é constituída pelas políticas de previdência social, de saúde e de assistência social (Sposati, 2009).

Para a Seguridade Social especificamente, a Constituição Federal de 1988 é, sem dúvidas, um divisor de águas. Com ela, dá-se início a uma ainda inconclusa

\footnotetext{
${ }^{34}$ Vide discussão sobre o tema no capítulo anterior.
} 
trajetória de reconfiguração do sistema nacional de políticas sociais, em direção a um modelo de segurança social que se baseia em direitos por meio de normas universalistas e critérios equânimes (Boschetti, 2006). De acordo com Boschetti:

\begin{abstract}
É importante destacar que este processo nacional se dá em um contexto marcado por disputas ideológicas desfavoráveis à construção de uma agenda de direitos, em que internacionalmente o pensamento econômico-liberal e conservador, praticamente hegemônico, busca o fortalecimento da iniciativa privada, regulada pelo mercado, o Estado Mínimo e a consequente desconstrução das políticas sociais, garantidas por direitos constitucionais. (Boschetti, 2006, p.28)
\end{abstract}

$\mathrm{Na}$ contramão da agenda neoliberal, a Constituição Federal de 1988 avançou em relação à anterior ao reconhecer um conjunto de direitos sociais, o que pode ser observado em seu artigo $6^{\circ}$.

Art. $6^{\circ}$ São direitos sociais a educação, a saúde, a alimentação, o trabalho, a moradia, o lazer, a segurança, a previdência social, a proteção à maternidade e à infância, a assistência aos desamparados, na forma desta Constituição. (Constituição Federal, 1988)

Mais adiante, no capítulo da Ordem Social, a Constituição Federal inova ao introduzir o conceito de Seguridade Social, que passa a expressar o novo pacto social a se construir fundado na solidariedade e na inclusão dos cidadãos em risco social (Constituição Federal, 1988).

Art. 194. A seguridade social compreende um conjunto integrado de ações de iniciativa dos Poderes Públicos e da sociedade, destinadas a assegurar os direitos relativos à saúde, à previdência e à assistência social. (Constituição Federal, 1988)

Neste mesmo capítulo, são inseridos os princípios orientadores da Seguridade Social:

- a universalidade da cobertura e do atendimento;

- a uniformidade e equivalência dos benefícios e dos serviços às populações urbanas e rurais; 
- a equidade e distributividade na prestação dos benefícios e dos serviços; a irredutibilidade do valor dos benefícios;

- a equidade na forma de participação no custeio;

- a diversidade da base de financiamento;

- o caráter democrático e descentralizado da gestão administrativa, com a participação da comunidade.

Conforme os preceitos orientadores, a adoção do conceito de Seguridade Social expressa o novo pacto social a se construir, fundado na solidariedade e na inclusão dos cidadãos em risco social.

Diante dos normativos legais, a Constituição Federal de 1988 transforma profundamente as normas do sistema de proteção social brasileiro no momento em que rompe com as noções de cobertura restrita a setores inseridos no mercado formal e afrouxa os vínculos entre contribuições e benefícios, gerando mecanismos mais solidários e redistributivos (Sposati, 2009).

E, essa consolidação constitucional do modelo de proteção social se dá por quatro elementos:

- o rompimento com a necessidade do vínculo empregatício contributivo;

- a transformação do conjunto de ações assistencialistas do passado em um embrião para a construção de uma política de assistência social amplamente inclusiva;

- o estabelecimento do marco institucional inicial para a construção de uma estratégia de universalização no que se refere às políticas de saúde, à educação básica, e;

- à proposição de fontes de financiamento de acordo com o Orçamento da Seguridade Social (Artigo 195, Constituição Federal/1988).

O afrouxamento do vínculo contributivo e a ampliação da visão de proteção social se materializam especialmente em duas determinações fundamentais para a garantia de direitos no Brasil (Schawtzer e Querino, 2002). A primeira diz que a assistência social será prestada a quem dela necessitar, independentemente de contribuição à seguridade social, e estabelece como um dos 
objetivos da assistência social a garantia de 1 (um) salário mínimo de benefício mensal à pessoa portadora de deficiência e ao idoso que comprovem não possuir meios de prover a própria manutenção ou de tê-la provida por sua família. Essa determinação constitucional corresponde ao que hoje é o Benefício de Prestação Continuada - BPC, da Assistência Social, direcionado à proteção de dois grupos:

- pessoas com $67^{35}$ anos ou mais e;

- incapacitados, incluindo aqueles com deficiências congênitas ${ }^{36}$. Em ambos os casos, exige-se que a renda familiar per capita do candidato ao benefício não ultrapasse um quarto do valor do salário mínimo.

A segunda determinação refere-se à equiparação dos direitos dos trabalhadores rurais ao dos trabalhadores urbanos e à garantia de uma proteção especial para o regime de economia familiar rural $^{37}$, em sua grande maioria trabalhadores e trabalhadoras informais, que viviam abaixo da linha da pobreza. De acordo com Fagnani (2011), Cabe destacar que estes trabalhadores apresentavam pouca ou nenhuma capacidade contributiva. Isto significa que o financiamento das aposentadorias e pensões rurais é, até hoje, majoritariamente não contributivo.

Além disso, mais duas conquistas da Constituição Federal de 1988, com impactos sociais, referem-se à unificação nacional do salário mínimo e à fixação em lei de que os benefícios previdenciários e assistenciais seriam vinculados a ele.

Outra inovação da Constituição Federal de 1988 é o surgimento dos benefícios não contributivos. Com relação a estes, e acordo com Sposati (2009, p.119):

Os benefícios não contributivos são aqueles cujo recebimento independe de contribuições prévias do indivíduo, diferente de parte dos benefícios previdenciários, que são contributivos e, portanto, acessíveis apenas quando o indivíduo se filia à previdência e recolhe ou paga um valor mensal.

\footnotetext{
${ }^{35}$ Com a aprovação do Estatuto do Idoso, por meio da Lei no 10.741 de 10 de outubro de 2003, a idade passou para 65 anos.

36 São aquelas adquiridas antes do nascimento ou mesmo posterior a tal, no primeiro mês de vida, seja qual for a sua causa.

37 De acordo com o art. 11, VII, da Lei ${ }^{\circ} 8.213 / 91, \S 1^{\circ}$, que dispõe, in verbis: "Entende-se como regime de economia familiar a atividade em que o trabalho dos membros da família é indispensável à própria subsistência e é exercido em condições de mútua dependência e colaboração, sem a utilização de empregados."
} 
No Sistema de Seguridade Social brasileiro, os benefícios não contributivos são o principal instrumento de políticas de proteção social para o alívio da pobreza, pois consistem na última rede de segurança para pessoas cuja renda familiar está abaixo de um patamar mínimo específico. Assim como na maior parte dos países em desenvolvimento, no Brasil prevalecem os benefícios não contributivos focalizados, em detrimento aos de caráter universal. Em geral, são concedidos para famílias comprovadamente pobres, podendo ainda ser também exigido que o beneficiário atenda a condicionalidades, como manter crianças na escola e a carteira de vacinação delas em dia ${ }^{38}$ (Jaccoub, 2010).

Para dar sustentabilidade financeira a este novo conceito de Seguridade Social, a Constituição previu a criação do Orçamento da Seguridade Social composto por fontes diferenciadas e exclusivas de financiamento, oriundas de contribuições de toda a sociedade. De acordo com Boschetti (2006), o art. 195 da Constituição determina as seguintes fontes para o financiamento da Seguridade Social como um todo:

- recursos orçamentários das três esferas de governo: da União, dos Estados, do Distrito Federal e dos Municípios;

- contribuições dos trabalhadores e empregadores; no que se refere à contribuição das empresas, cabe destacar a inclusão de contribuições sociais provenientes do faturamento e do lucro, além da folha de salários, de forma a assegurar melhor distribuição do peso de sustentação do sistema;

- recursos das receitas oriundas de loterias e;

• contribuições de importações.

Além dos aspectos citados, outros marcos fundamentais da Constituição Federal tangem não somente à institucionalização e ao aprofundamento no processo de descentralização política, como à ampliação da participação popular no que se refere às políticas sociais, através de desenhos de gestão inovadores baseados na lógica de Sistemas de Políticas Públicas. No campo da Seguridade Social, destaca-se a criação dos seguintes sistemas:

- Sistema Único de Saúde - SUS,

${ }^{38}$ Como o Programa Bolsa Família e os demais programas implantados, conforme veremos adiante. 
- Sistema Único de Assistência Social - SUAS e

- Sistema Nacional de Segurança Alimentar e Nutricional - SISAN.

Estes sistemas buscam desenhar as relações entre os entes federativos (União, Estados, Distrito Federal e Municípios), por três mecanismos principais:

• articulação e pactuação entre os três níveis de governo;

- instituição de transferências automáticas de recursos, fundo a fundo, baseadas em critérios como valores per capita ou metas acordadas entre as esferas de governo;

- implantação de formas concretas de participação e controle social, através de conselhos, formados por representantes da sociedade civil e de governos.

Tais determinações dão base para mudanças na gestão pública em relação a períodos anteriores, marcados por uma alta centralização de poder e de recursos públicos federais, que facilitavam barganhas políticas e iniquidades distributivas.

Podemos afirmar que o caminho percorrido desde a Constituição Federal/88 até os dias de hoje foi marcado por avanços e retrocessos. Um dos avanços refere-se ao significativo aumento no gasto social $^{39}$ e na cobertura contra riscos sociais $^{40}$ e à conformação de um amplo conjunto de programas de proteção e promoção social, por meio das políticas sociais.

De acordo com o Instituto de Pesquisa Econômica Aplicada - IPEA ${ }^{41}$, as políticas sociais são definidas dentro de dois objetivos:

- proteger o cidadão frente aos riscos e fatores que, independente de sua vontade, podem lançá-lo em situação de dependência ou vulnerabilidade ${ }^{42}$;

\footnotetext{
${ }^{39}$ Zauli, Eduardo Meira. Gastos Sociais, Pobreza e Desigualdade de Renda no Brasil. Pensar BH/Política Social, Agosto/Setembro 2005.

${ }^{40}$ Riscos sociais são aqueles decorrentes da vivência de situações que implicam na violação de direitos humanos e ameaçam a integridade física, psíquica e relacional, como violência intrafamiliar, abuso e exploração sexual, trabalho infantil, abandono, isolamento, situação de rua, dentre outras.

41 O IPEA é a instituição pública que fornece suporte técnico e institucional às ações governamentais para a formulação de políticas públicas,

42 Vulnerabilidade social é aquela decorrente do ciclo de vida, da situação de pobreza, das barreiras enfrentadas pelas pessoas com deficiência, da falta de acesso às políticas públicas, da falta de infraestrutura, da ocorrência de discriminações e apartações.
} 
- promover a geração de oportunidades e de resultados, como instrumento de justiça e equidade.

A figura que segue pretende sistematizar o atual sistema nacional de políticas sociais (IPEA, 2010).

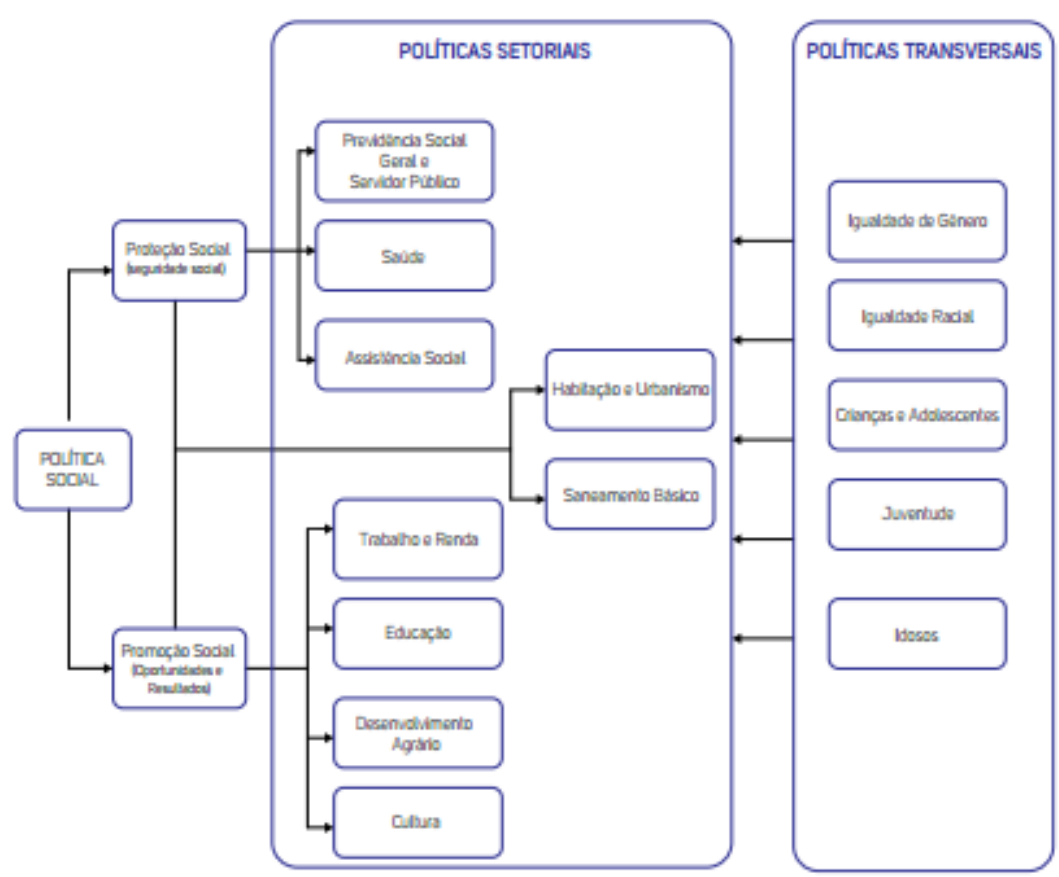

Figura 1- As políticas sociais no Brasil.

Fonte: IPEA, Política Social no Brasil, 2011.

O sistema referente à proteção social agrupa as políticas voltadas à seguridade (previdência, assistência e saúde), enquanto que o sistema referente à promoção reúne os instrumentos que pretendem garantir aos cidadãos oportunidades de participação econômica. Estes instrumentos vão desde a educação até iniciativas específicas voltadas ao acesso ao mercado, como as políticas públicas de fortalecimento da agricultura familiar e economia solidária.

É com base neste conjunto amplo de políticas sociais é que são desenvolvidos os programas e ações que formam as políticas setoriais e transversais, como é o caso da política de Assistência Social, conforme veremos a seguir. 


\section{2. \\ Política de Assistência Social: inovação no acesso aos direitos sociais}

No Brasil, a política de Assistência Social, conforme o artigo 203 da Constituição define que essa deve ser prestada "a quem dela necessitar, independente de contribuição à seguridade social". No caso desta política, nos encontramos num processo recente de implantação das suas concepções, que incluem a proteção da família, a habilitação e reabilitação das pessoas com deficiência, a promoção da integração com o mercado de trabalho, dentre outros, merecendo destaque para a sua concretização a implantação do Sistema Único de Assistência Social - SUAS.

E, mesmo diante da construção das legislações sociais, especialmente daquelas previstas na $\mathrm{CF} / 88$, no que se refere à política de Assistência Social. estas condições não foram suficientes para a melhoria das condições de vida da população (Draibe, 1993, p.53). O período dos governos brasileiros desde 1985 (Sarney) até 2002 (Fernando Henrique Cardoso) trazem propostas de conformação democrática, que no discurso oficial visam romper com o clientelismo e patrimonialismo do Estado, propondo mudanças no sistema político, econômico, que teriam como consequência o crescimento e o desenvolvimento do país (Couto, 2010, p.142).

Porém na prática, o que podemos observar é que os diversos planos econômicos, ${ }^{43}$ no mesmo momento em que o Brasil promulgava a Constituição com uma série de previsões no que se refere a proteção social e, que previam legislações complementares para a sua implantação, aliados as organizações das forças conservadoras impediu que estas mudanças ocorressem.

Por outro lado, o Brasil torna-se signatário de acordos com o Fundo Monetário Internacional (FMI) e com o Bando Mundial, de acordo com as orientações contidas no Consenso de Washington ${ }^{44}$, inspirado pelo ideário

\footnotetext{
43 Planos econômicos do Brasil pós governo militar: Cruzado (início de 1986), Cruzadinho (meados de 1986), Cruzado II (final de 1986), Bresser (junho de 1987), Verão (janeiro de 1989), Collor (março de 1990) e Collor 2 (janeiro de 1991) e o Plano Real (1994).

${ }^{44}$ Consenso de Washington é um conjunto de medidas - que se compõe de dez regras básicas formulado em novembro de 1989 por economistas de instituições financeiras situadas
} 
neoliberal e indicava a desestruturação dos sistemas de proteção social vinculados às estruturas estatais e a orientação para que os mesmos passassem a ser gestados pela iniciativa privada.

Estas orientações são opostas ás previsões contida na $\mathrm{CF} / 88$, que previa acesso universal ás políticas sociais, com ampla participação e financiamento do Estado. Porém, esta linha teórica vem ao encontro da herança oligárquica, patrimonialista e autoritária dos governos, que compreendem o papel do Estado sob esta ótica. Conforme Sander (2000), o Estado brasileiro historicamente, sempre foi máximo para os interesses privados e mínimos para as demandas por políticas sociais para o povo.

Apesar da previsão constitucional, as determinações legais ali consiganadas demandaram vários desdobramentos para que de fato se materializassem por meio da sua regulamentação específica. A Lei Orgânica da Assistência Social -LOAS, dada a baixa capacidade de reivindicação pelos seus usuários, arrastou-se por um longo processo de cinco anos e somente em dezembro de 1993 foi aprovada (Lei ${ }^{\circ}$ 8.742), no Governo de Itamar Franco, como resultado da pressão da sociedade civil, dos organismos de classe e do Ministério Público, que ameaçava processar o Governo por descuido na área (Paiva, 1993).

A aprovação da LOAS foi um momento de avanço democrático, pois ao regulamentar as disposições constitucionais, assegurou à assistência social o caráter de política pública, e aos seus usuários, detentores de fato, de direitos, por meio da prestação de serviços e benefícios sistemáticos e continuados, e de programas e projetos, que devem contar com recursos materiais e financeiros regulares e obrigatórios. Segundo Boschetti (1998b,p.12), essa lei representou o "fim da travessia do deserto", ao superar a compreensão corrente de dever moral

em Washington D.C., como o FMI, o Banco Mundial e o Departamento do Tesouro dos Estados Unidos, fundamentadas num texto do economista John Williamson, do International Institute for Economy, e que se tornou a política oficial do Fundo Monetário Internacional em 1990, quando passou a ser "receitado" para promover o "ajustamento macroeconômico" dos países em desenvolvimento que passavam por dificuldades. As dez regras do Consenso são: disciplina fiscal; redução dos gastos públicos; reforma tributária; juros de mercado; câmbio de mercado; abertura comercial; investimento estrangeiro direto, com eliminação de restrições; privatização de estatais; desregulamentação (afrouxamento das leis econômicas e trabalhistas e; direito à propriedade intelectual. 
de ajuda, passando a atende-la como dever legal de garantia de benefícios e serviços sociais.

Os avanços legais e institucionais bem como os mecanismos de participação popular implantados desde então, foram graduais e significativos. Dentre eles destacam-se:

a) Criação do Fundo Nacional de Assistência Social (FNAS) - Decreto n ${ }^{\circ}$ 1.605, de 25/8/1995;

b) Efetiva implantação e funcionamento dos Conselhos de Assistência Social em todas as esferas de governo;

c) Organização da assistência social como um sistema descentralizado e participativo, composto, nas três esferas de governo, por órgãos gestores e por instâncias deliberativas de natureza colegiada.

Dentre as orientações contidas na LOAS são de extrema importância a definição e os objetivos da assistência social, bem como suas diretrizes, princípios, organização e gestão, ações e financiamento, priorizando a descentralização político-administrativa e a participação da população no processo de formulação e de controle das ações em todos os níveis. Além disso, apresenta duas funções básica importantes: garantir o que está declarado na Constituição Federal, pois a LOAS é uma lei complementar que dá concretude ao direito proclamado e, definir, detalhar e delimitar a natureza, o significado e o campo característico da assistência social na área da seguridade social (Boschetti, 1998b).

Percebe-se que mesmo após seu reconhecimento legal e após da regulamentação da política por meio da legislação infraconstitucional na atualidade, e a política da Assistência Social continua a ser alvo de muitas resistências para a sua implementação.

Sob a égide do discurso neoliberal, assistiu-se a diminuição dos investimentos produtivos, acompanhados da redução do investimento público de infra estrutura física e social, tendo como uma das suas consequências mais penosas o crescimento da pobreza e da desigualdade social (Behring, 2003).

De acordo com Draibe (1993), os eixos da política social propostas no bojo das estratégias conservadoras de ajustamento econômico são a focalização, a 
privatização e a descentralização. Assim sendo, estas transformações oriundas do ajuste macroeconômico e da reestruturação produtiva, aliada a uma inserção passiva e subordinada do país na economia global, colaboraram efetivamente para o agravamento do quadro social, a partir dos anos 90, caracterizado pelos baixos níveis de crescimento econômico; deterioração das condições de trabalho e renda e da população; pelo aumento das desigualdades sociais; e pela nova direção regressiva das políticas sociais (Carvalho, 1995a).

No campo político, observou-se um deslocamento da pobreza como "questão política" para um lugar de não-política, onde é concebida para ser administrada por práticas de filantropia. Apesar da vigência da Loas, o governo FHC decidiu criar um sistema paralelo: o Programa Comunidade Solidária (PCS), por meio da MP 813 de $1^{\circ}$ de janeiro de 1995 , como carro chefe da política social do seu governo, comandado pela primeira-dama.

O PCS desempenhou importante papel simbólico na disseminação de uma imagem de inovação da gestão pública, pois não possuía prerrogativas executivas, sendo voltado para novas formas de articulação entre ministérios e organizações da sociedade civil e para a integração das três esferas de governo em ações conjuntas de combate à exclusão social. O PCS tratava-se de um bom exemplo da relação desse governo com a concepção constitucional de Seguridade Social, isto é, um exemplo de como um programa independente do sistema e ignorando a Loas, que apresentou ao longo dos últimos anos uma dotação orçamentária sempre superior ao Fundo Nacional de Assistência Social (FNAS), foi via de formulação da legislação do terceiro setor, reproduziu o tradicional primeirodamismo e foi alvo de clientelismo ao longo da sua existência.

Para Mota (1995) as reformas no sistema de Seguridade Social brasileiro ocorreram sob o comando da classe burguesa, que, além da força e coerção, dotam de novos conteúdos de as concepções políticas e históricas dos trabalhadores brasileiros, instituindo o cidadão consumidor ao invés do cidadão trabalhador; e esse processo, com todas as suas contradições, emerge um modo de enfrentamento das desigualdades sociais baseada na "cultura da solidariedade social", que se representa em "políticas de combate à pobreza", "comunidades solidárias" ou na expansão dos “programas de assistência social”. É na estreita fronteira entre 
direitos e carências-fio da navalha -, figura adotada por Telles (1998), que os programas de transferência de renda transitam.

É importante acrescentar que, para se materializar a política de Assistência Social, por meio de medidas e orientações são necessárias para a sua operacionalização um conjunto de ações que devem repercutir na proteção social dos seus beneficiários. Por isso, em consonância com a LOAS, em 2004, ou seja, 15 anos após a promulgação da Constituição Federal, ocorreu a aprovação da Política Nacional de Assistência Social - PNAS.

A PNAS é a diretriz da assistência social, composta por um plano com base em princípios democráticos, com funções de inserção, prevenção, promoção e proteção, integralizadoras, cujas proposições formam um conjunto de políticas sociais determinantes em âmbito nacional.Para tanto, são desenvolvidos ações, programas, projetos e benefícios, com vistas a garantir o atendimento às necessidades básicas dos segmentos populacionais vulnerabilizadas por diversas faces da questão social.

Em 2005, publica-se a Norma Operacional Básica do Sistema Único de Assistência Social (NOB-SUAS). O SUAS é um sistema público não contributivo, descentralizado e participativo, que tem por função a gestão do conteúdo específico da Assistência Social no campo da proteção social brasileira (MDS, 2005, p.86). O modelo do SUAS define a família como núcleo social básico e organiza os benefícios e serviços assistenciais em uma rede hierarquizada territorialmente, com definição de responsabilidade de cada esfera governamental e dos critérios de funcionamento do sistema.

Em 2005 começaram a ser implantadas as unidades públicas de referência do SUAS, voltados à proteção básica e especial. Previstos pela PNAS, os Cras e CREAS se expandiram rapidamente, contando principalmente com o cofinanciamento fundo a fundo. As unidades municipais existentes e que já operavam com o então chamado Programa de Atenção Integral à Família (PAIF), passaram a ser consideradas Centros de Referência em Assistência Social CRAS, sendo incentivadas a realizar o reordenamento necessário às normativas do equipamento e do serviço. O mesmo ocorreu na proteção especial, onde as unidades municipais que implementavam o programa Sentinela, voltado ao enfrentamento da violência e abuso sexual contra crianças e adolescentes, foram 
reconhecidas como Centros de Referência Especializados em Assistência SocialCREAS.

Estes dois grupos iniciais conformavam, em 2005 (Censo Suas, 2004), 2.292 unidades públicas em reordenamento, mas já identificadas aos novos equipamentos do SUAS. Em agosto de $2013^{45}$, este quantitativo já havia sido multiplicado mais de 4 vezes, ultrapassando 10.000 unidades públicas cofinanciadas pelo MDS, sendo c 7.507 CRAS (em 5.527 municípios) e 2.318 CREAS (em 2.073 municípios), além de 291 novos equipamentos: os Centros de Referência para População em Situação de Rua - Centro POP , em 246 municípios brasileiros.

A estratégia de alocação dos equipamentos da proteção básica em todos os municípios brasileiros, preconizada pela NOB/SUAS, cuja meta foi perseguida desde o princípio pela Comissão Intergestores Tripartite - CIT e pelo Conselho Nacional de Assistência Social - CNAS vem sido gradativamente ampliada. A universalização do acesso às unidades públicas e seus serviços obrigatórios com a integralidade da cobertura na proteção básica em todos os territórios vulneráveis ${ }^{46}$ conforme tipificado pela NOB/Suas ainda é uma meta a ser alcançada.

Observa-se que ao lado da ampliação da rede, tanto em equipamentos como em aumento da capacidade de oferta, ocorreu o crescimento dos recursos humanos no SUAS. O Censo SUAS 2012 identificou cerca de 260 mil trabalhadores nas unidades públicas e na gestão no DF, estados e municípios. Em 2011, o Censo SUAS da Rede Privada identificou quase 330 mil trabalhadores atuando nas entidades de assistência social. Porém, apesar dos avanços, ainda é necessário a ampliação de rede de equipamentos e de recursos humanos para atender a demanda da população que utiliza os serviços da assistência social nos municípios brasileiros, pois conforme observamos a demanda por serviços é muito maior que a capacidade de atendimento.

Com relação ao financiamento do SUAS, a consolidação das transferências federais por meio de pisos e blocos regulares e automáticos em cada nível de

\footnotetext{
${ }^{45}$ De acordo com o Censo Suas 2012, do MDS.

${ }^{46}$ Destaca-se nesse rol de ações a constituição e operação de equipes volantes com o objetivo de chegar às populações mesmo em territórios mais isolados, especialmente na região Amazônica.
} 
proteção, e assentados em critérios pactuados e equitativos de partilha representou a garantia da presença do fundo público na sustentação dos serviços continuados.

No ano de 2014, mais de 68 bilhões de reais foram mobilizados para a função 08 - Assistência Social. Segundo o IPEA (2012), em 1995 a política de assistência social contava com recursos públicos federais da ordem de $0,08 \%$ do PIB. Estes recursos representavam, 15 anos depois, em 2010, cerca de 1,08\% de um PIB nacional significativamente superior. $\mathrm{O}$ crescimento de recursos federais foi constante, seja no que diz respeito aos serviços e programas, seja aos benefícios. Estudo do SPO/MDS (2012) avaliando a trajetória entre 2005 e 2012, observa um crescimento de $153 \%$ nos recursos aplicados pelo Ministério na política de Assistência Social. Neste período, os recursos destinados ao BPC tiverem crescimento da ordem de $265 \%$, os recursos destinados ao PBF um crescimento de $108 \%$ e aqueles destinados aos serviços, gestão, programas e projetos cresceram mais de $150 \%$. O aumento de recursos destinado a política de assistência social tem sido observado também entre as esferas estadual e, municipal.

Além disso observamos um esforço do poder público para aperfeiçoar os instrumentos de gestão e coordenação federativa, o que pode ser verificados com a criação do Índice de Gestão Descentralizada do SUAS (IGD-SUAS) aos estados e aos municípios.

Esses recursos destinam-se ao aprimoramento da gestão e, em 2012, mobilizaram mais de $\mathrm{R} \$ 139$ milhões $^{47}$ e tem como objetivo a ampliação dos resultados positivos na gestão e o alcance de patamares de qualidade do Sistema. Além disso, permitem aos entes federados potencializar medidas e fortalecer sua capacidade de operação com investimentos em equipamentos, recursos humanos ou sistemas tais como de vigilância sócio assistencial ou de monitoramento.

Por fim, e não menos importante, cabe ressaltar a tipificação e padronização dos serviços sócio assistenciais, visando homogeneizar e ampliar as garantias de oferta à população e instituir no território unidades públicas associadas a rede de serviços e a fluxos dentro da política e entre políticas e instâncias de garantia de direitos. A organicidade dos serviços e a estruturação da

\footnotetext{
${ }^{47}$ De acordo com MDS, 2012.
} 
gestão face as diferenciadas demandas e responsabilidades de proteção configuram aspectos estratégicos na consolidação do SUAS. Os Pactos de Aprimoramento da Gestão Estadual e, mais recentemente, Municipal, visam responder a tais questões. Apontam para prioridades vinculadas a prazos, metas e resultados no âmbito da estrutura organizacional, assessoria e apoio técnico, sistemas de informação, entre outros. São instrumentos normativos e institucionais que buscam desenvolver e aperfeiçoar os meios imprescindíveis para que a política possa exercer a sua função protetiva no campo complexo dos direitos sócio assistenciais.

Após duas décadas e meia da sua regulamentação legal, a assistência social tem enfrentado o agigantamento da determinação capitalista de expansão e acumulação, por meio da reestruturação produtiva, que trata sobretudo da reestruturação de um processo de acumulação de capital globalizado. Em face dos altos índices de produtividade decorrentes desse processo, o capital readquiriu um poder quase absoluto sobre o trabalho, sendo o desemprego de longa duração, a precarização das relações de trabalho e a heterogeneidade ocupacional suas expressões mais nocivas (Montaño, 2002).

$\mathrm{Na}$ atualidade, ao refletir sobre os 10 anos de SUAS, 20 anos de LOAS e fatos inaugurais como a PNAS-2004 e NOB-SUAS 2005 não podemos deixar de relembrar as considerações de Edval Bernardino (2013) sobre o DNA éticopolítico da Política Nacional de Assistência Social e, sobretudo, do SUAS. Cabe destacar que a legalidade das normas e dispositivos não significou o alcance da legitimidade da política bem como o entendimento de um projeto capaz de produzir mudanças sociais. "Essa característica política ainda se faz necessária para que seja superada a timidez ainda presente na afirmação da política de Assistência Social na luta política" (Sposati, 2013, p. 21).

A este se soma ainda o contingente da população atendida pela política de assistência social - que não permite considerá-la focalizada (Sposati, 2009) -, as diversidades regionais da Gestão Integrada de Serviços, Benefícios e Transferência de Renda: a extensão territorial e a complexidade geográfica e de ocupação dos territórios, que tornam particularmente complexa e desafiadora a elaboração e a implementação de uma política pública que possa assegurar a universalização da cobertura. 
Concordamos que a política de Assistência Social, desde a Constituição Federal de 1988, apresenta inegáveis avanços, porém ainda há contradições e descompassos no campo da gestão pública que tornam desafiadora a implementação da política com ofertas qualificadas. Ao passo em que o pacto federativo e a descentralização político administrativa favorecem o processo de gestão e a organização das ofertas em correspondência às realidades locais, o fortalecimento das gestões públicas municipais e estaduais no campo da assistência social ainda é pauta central para o SUAS, envolvendo aspectos diversos que vão desde a alocação de recursos públicos na área em um cenário de disputas pelos fundos públicos, passando pela composição de quadros efetivos de servidores públicos, até as dificuldades para operacionalizar a execução orçamentária, considerando as normativas e legislações relacionadas (Collin, 2013)

A rotatividade dos profissionais no âmbito da gestão pública, a alternância de governos, o domínio dos instrumentos legais e a implementação em curso da política de educação permanente nos municípios e estados são aspectos associados aos desafios ainda presentes de implantação da política com efetividade. O enfrentamento destes pontos demarca um novo estágio expresso no Pacto de Aprimoramento da Gestão Estadual e Municipal e na NOB/SUAS 2012, que tem como eixos centrais o aprimoramento da gestão, a qualificação das ofertas e o fortalecimento do controle e da participação social.

Após um período inicial de implantação do Sistema, a aprovação da Lei $12.435 / 2011^{48}$, bem como a NOB/SUAS 2012, anunciam e subsidiam novos caminhos para a assistência social no Brasil.

As estratégias previstas na NOB/SUAS 2012 que tornam monitoramento, avaliação e planejamento elementos indissociáveis; as mudanças que atrelam financiamento a resultados e que conferem maior flexibilidade e agilidade na utilização dos recursos públicos; e as conquistas no campo da gestão do trabalho, em especial a autorização da utilização de recursos do cofinanciamento federal para o pagamento de profissionais que compõem as equipes de referência, a proposta robusta de capacitação por meio do CapacitaSUAS e a formação da Rede

\footnotetext{
${ }^{48}$ Esta lei altera a Lei no 8.742 , de 7 de dezembro de 1993, que dispõe sobre a organização da Assistência Social.
} 
Nacional de Capacitação e Educação Permanente do SUAS são medidas já em curso que pretendem contribuir para a mudança de cenário em relação aos desafios atuais postos ao Sistema.

Outro aspecto que merece destaque é a aprovação do Pacto de Aprimoramento da Gestão Municipal e Estadual que conferiu centralidade à gestão integrada no período de 2014-2017. E, como desafios para os próximos anos, a identificação das famílias em situação de vulnerabilidade social e risco pessoal e social, sua inclusão no Cadastro Único, o acesso à transferência de renda do PBF e ao BPC e seu acompanhamento nos serviços sócio assistenciais constituem prioridades das Gestões Federal, estaduais e municipais para o aprimoramento do SUAS.

\section{3.}

As primeiras experiências de transferência de renda no Brasil

No contexto da regulamentação da implantação da política de Assistência Social, na década de 1990, presenciamos no Brasil o surgimento das primeiras experiências de programas de transferência de renda às famílias com condicionalidades, com experiências pioneiras em Campinas (SP) e do Distrito Federal em 1995. A partir de então, um conjunto significativo de programas com esse desenho, começam a ser desenvolvidos no país.

O primeiro programa federal de transferência de renda com condicionalidades foi o Programa de Erradicação do Trabalho Infantil (PETI), em 1996. O programa apresenta três componentes: benefício financeiro, atividade socioeducativa e oferta de ações de qualificação profissional e geração de trabalho e renda para adultos de famílias com crianças em situação de trabalho infantil e, visa a transferência de renda paras as famílias cujos jovens encontram-se em situação de trabalho infantil.

Para que os mesmos possam sair desta situação, os jovens são inseridos em ações sócio educativas e as famílias destes jovens recebem o repasse do recurso financeiro. 
No período de 2001 a 2003, o Governo lançou quatro programas de transferência de renda direta às famílias. O primeiro, o Programa Nacional de Renda Mínima vinculada à Educação, conhecido como Bolsa Escola, instituído pela Lei $\mathrm{n}^{\circ} 10.219$ de 11 de abril de 2001, regulamentado pelo Decreto $\mathrm{n}^{\circ}$ 3.823/01, tinha como público-alvo as famílias com renda per capita mensal de até $\mathrm{R} \$ 90,00$ e com a presença de crianças de 6 a 15 anos na sua composição familiar e devidamente matriculada na rede de Ensino Básico. O Programa era estendido a todos os municípios brasileiros e a responsabilidade da sua implantação estava a cargo do Ministério da Educação. O valor do benefício era de R \$ 15,00 mensais por criança, até o limite de $\mathrm{R} \$ 45,00$ (3 crianças) por família. Como condicionalidade, as crianças deveriam ter uma frequência mínima de $85 \%$ mensal.

Outro programa criado foi o Programa Bolsa Alimentação, instituído pela Medida Provisória $n^{\circ}$ 2.206-1 de 10 de setembro de 2001, posteriormente regulamentado pelo Decreto $\mathrm{n}^{\circ} 3.934$, de 20 de setembro de 2001, que beneficiava gestantes, nutrizes e crianças de até 6 anos e 11 meses em risco nutricional, pertencentes à família com renda per capita mensal de até $\mathrm{R} \$ 90,00$. O Ministério da Saúde era responsável pelo Programa, que transferia $\mathrm{R} \$ 15,00$ mensais por pessoa, a até o limite de $\mathrm{R} \$ 45,00$ (3 pessoas) por família, para a melhoria da sua alimentação. O gasto do valor do benefício recebido pela família não era controlado pelos gestores do Programa e, a agenda de condicionalidades para a manutenção do recebimento do benefício consistia nos seguintes compromissos para a família: participação em ações básicas de saúde, com enfoque predominantemente preventivos; atendimento pré-natal; calendário de vacinação em dia; acompanhamento do crescimento e do desenvolvimento infantil; incentivo ao aleitamento materno e; atividades educativas em saúde.

O Auxílio Gás também foi um dos programas de renda criados pelo Governo Federal. Foi instituído pela Medida Provisória n ${ }^{\circ} 18$ de 28 de dezembro de 2001, regulamentado pelo Decreto $\mathrm{n}^{\circ} 4.102$ de 24 de janeiro de 2002, estava sob a gestão do Ministério de Minas e Energia. Não era um programa de transferência de renda condicionada, mas sim um benefício financeiro transferido ás famílias pobres (renda per capita mensal inferior a 1/2 salário mínimo) para 
compensar o aumento do preço do gás de cozinha, resultante da retirada do subsídio a esse produto. A família beneficiada recebia $\mathrm{R} \$ 15,00$ por bimestre.

Porém, estes programas não surtiram os efeitos desejados, visto que eram fragmentados e beneficiavam as mesmas famílias e, em alguns casos, famílias com perfil ficavam sem receber os benefícios. Conforme registram Silva et al (2004, p.132):

Esses programas foram criados em uma conjuntura socioeconômica marcada pelo crescimento acentuado do desemprego, acompanhando das formas de ocupação precárias e instáveis sem a proteção social garantida pela previdência social, rebaixamento do rendimento da renda proveniente do trabalho, crescimento da violência, principalmente nos grandes centros urbanos, ampliação dos índices de pobreza e da desigualdade social. (Silva et al, 2004, p.132)

Observamos que apesar dos programas implantados, no que se refere quadro social os resultados do governo de FHC são desastrosos (Lesbaupian, 1999): aumento da concentração de renda (Gonçalves, 1999); altíssimo índice de desemprego (Mattoso, 199); tentativas constantes de desmontar os direitos trabalhistas (Netto, 1999); processo de privatização intenso e; várias reformas na $\mathrm{CF} / 88$, principalmente no que se refere ao campo dos direitos sociais (Comparato, 1999).

Esse resultado foi produzido pela política econômica adotada, que submeteu a economia brasileira aos ditames do mercado internacional, tornando o Brasil inteiramente dependente dos mercados especulativos.

Apesar da criação dos programas de transferência de renda, estas se mostravam insuficientes para atender as demandas de combate à pobreza no país. Além disso, havia uma sobreposição de benefícios para a mesma família, enquanto uma parcela importante da população brasileira pobre permanecia descoberta pelos programas. Havia a necessidade urgente da ampliação e da articulação da rede de proteção social brasileira para que fosse possível a superação dos níveis de desigualdade no pais, bem como a articulação para que as políticas sociais fossem de fato cumpridas, de acordo com a previsão legal contida na $\mathrm{CF} / 88$ e não mais vistas como benesse do Estado e ligada a cultura política do favor, do clientelismo e do patrimonialismo. 
As políticas e programas implementadas no início do mandato do presidente Lula foram fundadas com forte apelo social, o que fortaleceu ainda mais a primazia dos PTR. A temática foi posta de modo mais contundente e sistemático a partir de um diagnóstico elaborado pela equipe de transição do governo Lula, que indicou vários problemas na implmentação dos PTR, justificando a necessidade da unificação destes, tendo como objetivo manter um único programa no País.

De acordo com a avaliação do Governo, apesar desses planos terem sido um avanço nas políticas sociais brasileiras, eles ignoraram a existência de programas semelhentes nos municípios e/ou estados e não conseguiram superar problemas tradicionais, como a pulverização de recursos, o elevado custo administrativo, a sobreposição de público-alvo, a ausência de coordenação e de perspectiva intersetorial (Cohn e Fonseca, 2004).

Assim sendo, a partir da articulação interministerial, coordenada pela Casa Civil da Presidência da República, formulou-se um novo programa, denominado Programa de Transferência Direta de Renda com Condicionalidades, criado pelo Programa Bolsa Família de acordo com a Lei n ${ }^{\circ}$ 10.835/2004 conforme veremos mais adiante.

\section{4 . \\ Para além da transferência de renda, a luta contra a fome como prioridade de gestão: o Fome Zero}

Josué de Castro, há mais de 60 anos atrás demonstrou que a fome não era um fenômeno natural e posteriormente assumiu importante papel na consolidação da Agência das Nações Unidas para a Alimentação e Agricultura (FAO), orientou e inspirou a constituição de uma agenda pública de segurança alimentar e nutricional no Brasil, que viria a se concretizar décadas depois.

A partir de 1993, a campanha "Ação da Cidadania contra a Fome, a Miséria e pela Vida", liderada pelo sociólogo Herbert de Souza, o Betinho, provocou forte mobilização da sociedade civil contra a fome no país. Nesse período, é criado o Conselho Nacional de Segurança Alimentar e Nutricional - 
CONSEA, instituído enquanto instância de assessoramento à Presidência da República, composto por sociedade civil e governo.

Este conselho atuou muito articulado com a campanha contra a fome, que então ocorria. Porém, encontrou dificuldades nos seus encaminhamentos frente à rigidez da política econômica, que era praticada em bases bastante ortodoxas. Seu principal momento foi a realização da $1^{\text {a }}$ Conferência Nacional de Segurança Alimentar, em 1994, que fixou diretrizes para uma política de segurança alimentar. Pouco depois o conselho foi extinto, como um dos primeiros atos do Presidente Fernando Henrique Cardoso, cujo governo iniciou-se em 1995. O período que se seguiu, entre 1995 e 2002, embora significando um retrocesso na relação entre governo e sociedade, foi rico na elaboração conceitual sobre o tema da segurança alimentar e nutricional e na organização da sociedade civil, com a criação do Fórum Brasileiro de Segurança Alimentar e Nutricional (FBSAN), em 1998.

A identificação da fome como forma aguda de pobreza e exclusão social e econômica, o processo de participação e mobilização da sociedade civil e a determinação política do Presidente Lula, que nos primeiros dias do seu governo apontou a luta contra a fome como a prioridade da sua gestão, impulsionaram a criação do Programa Fome Zero em 2003, que consistiu num esforço para delinear políticas específicas para aliviar a pobreza extrema, por meio de uma abordagem interdisciplinar para explicar e intervir no fenômeno da fome, por meio de uma estratégia multissetorial.

O Programa se apresenta, para a sociedade como uma resposta do Estado ao seu papel de fazer cumprir o direito humano à alimentação e, foi a "ideia força", prioritária e orientadora das políticas sociais no Brasil. Foi também a partir do Programa, que foram retomados e fortalecidos os processos de construção coletiva e participação social como as conferências e o CONSEA (Conselho Nacional de Segurança Alimentar e Nutricional), bem como alguns aspectos institucionais, dentre os quais podemos destacar:

- a criação do Ministério do Desenvolvimento Social e Combate à Fome, em 2004, como órgão responsável por cinco esferas da política social: Assistência Social, Bolsa Família, Segurança Alimentar e Nutricional, Inclusão Produtiva e Avaliação e Gestão da Informação; 
• a inclusão da alimentação como direito na Constituição Federal;

- a aprovação da Lei Orgânica de Segurança Alimentar e Nutricional LOSAN;

- a criação do Sistema Nacional de Segurança Alimentar e Nutricional SISAN - e;

- a criação e a implementação de programas como o Bolsa Família e o Programa de Aquisição de Alimentos - PAA, bem como a aprovação da nova Lei da Alimentação Escolar.

\section{Eixos Articuladores}

Os programas do Plano Fome Zero foram organizados a partir de quatro eixos articuladores de proteção e promoção social: ampliação do acesso aos alimentos, fortalecimento da agricultura familiar, geração de renda, articulação, mobilização e controle social, como mostra a figura a seguir.

\begin{tabular}{|c|c|}
\hline EIXOS & PRINCIPAIS PROGRAMAS \\
\hline $\begin{array}{l}\text { Ampliação do } \\
\text { acesso aos } \\
\text { alimentos }\end{array}$ & $\begin{array}{l}\text { Programa Bolsa Familia - PBF } \\
\text { Programa Nacional de Alimentação Escolar - PNAE } \\
\text { Rede de Equipamentos Públicos de Alimentação e Nutrição } \\
\text { (Restaurantes Populares, Cozinhas Comunitárias, Bancos de } \\
\text { Alimentos) } \\
\text { Cisternas de Água } \\
\text { Distribuição de Vitamina A e Ferro } \\
\text { Distribuição de Alimentos a grupos populacionais especificos } \\
\text { Sistema de Vigilăncia Alimentar e Nutricional - SISVAN }\end{array}$ \\
\hline $\begin{array}{l}\text { Fortalecimento } \\
\text { da agricultura } \\
\text { familiar }\end{array}$ & $\begin{array}{l}\text { Programa Nacional de Fortalecimento da Agricultura Familiar - } \\
\text { PRONAF (financiamento e seguro) } \\
\text { Programa de Aquisição de Alimentos }\end{array}$ \\
\hline $\begin{array}{l}\text { Geraçăo de } \\
\text { renda }\end{array}$ & $\begin{array}{l}\text { Economia Solidária } \\
\text { Microcrédito Produtivo Orientado } \\
\text { Qualificaçăo social e profissional }\end{array}$ \\
\hline $\begin{array}{l}\text { Articulação, } \\
\text { mobilização e } \\
\text { controle social }\end{array}$ & $\begin{array}{l}\text { Conselhos de Segurança Alimentar e Nutricional -CONSEAs } \\
\text { Educação Cidadã e Mobilização Social }\end{array}$ \\
\hline
\end{tabular}

Quadro 2- Eixos articuladores do Fome Zero. Fonte: Elaboração da autora. 
Após a apresentação da figura ilustrativa, seguir passaremos a descrever os quatro eixos do Programa Fome Zero.

\section{Ampliação do Acesso aos Alimentos}

A discussão sobre o acesso à alimentação, no contexto de construção do Fome Zero e da Política Nacional de Segurança Alimentar e Nutricional, é marcada pelo pressuposto de que o problema da fome não é uma questão de indisponibilidade de alimentos. O Brasil produz o suficiente para alimentar toda sua população, porém milhões de pessoas não têm o acesso garantido, porque não tem poder aquisitivo suficiente para comprar os alimentos que precisam ou porque não tem disponíveis os meios de produção dos alimentos.

O conjunto de programas e ações propostos que compõem este eixo busca ampliar as condições de acesso a alimentos saudáveis e adequados, principalmente às famílias de mais baixa renda. Envolve ações ligadas ao MDS, Ministério da Educação (MEC) e Ministério da Saúde (MS). A iniciativa de maior impacto foi a instituição e rápida expansão de um amplo programa de transferência de renda condicionada, voltado às famílias em situação de pobreza, o Programa Bolsa Família - PBF, descrito e analisado mais adiante.

Além da transferência de renda, foram instituídas ou ampliadas iniciativas que fazem com que os alimentos cheguem aos mais vulneráveis à fome, seja em forma gratuita ou subsidiada. Dentre elas, destaca-se o Programa Nacional de Alimentação Escolar - PNAE, um dos mais antigos programas de alimentação brasileiro, que promove a oferta de refeições aos estudantes da rede pública de ensino durante o período escolar, de forma a contribuir para o crescimento e o desenvolvimento biopsicossocial, a aprendizagem, o rendimento escolar e a formação de hábitos alimentares saudáveis. Deste as ações do Programa destacam-se:

- a ampliação de $130 \%$ do valor per capita repassado por aluno;

- a extensão da alimentação escolar para alunos matriculados em creches, ensino fundamental e na educação de jovens e adultos;

- a extensão do programa ao ensino médio; 
- a garantia à agricultura familiar do fornecimento de, pelo menos, 30\% do total adquirido em alimentos pelo Programa, o que significou uma extraordinária ampliação do mercado para essa modalidade de agricultura, que agrega os pequenos e médios produtores brasileiros, em sua maioria.

Como forma de ofertar refeições gratuitas ou a preços subsidiados, foi implementada, a partir de 2003, uma rede de equipamentos públicos de alimentação e nutrição, composta por Restaurantes Populares, Cozinhas Comunitárias e Bancos de Alimentos, em parceria com governos estaduais e municipais, que são responsáveis em nível local pela gestão e manutenção dos equipamentos.

Foi criada também, enquanto ação emergencial voltada a pessoas em situação de insegurança alimentar e nutricional, pertencentes a grupos populacionais específicos ou atingidas por adversidades climáticas, a ação Distribuição de Alimentos a Grupos Populacionais Específicos. Essa ação atende grupos remanescentes de quilombos, famílias acampadas que aguardam o programa de reforma agrária, comunidades de terreiros, povos indígenas, atingidos por barragens, pescadores artesanais e populações residentes em áreas vítimas de calamidades.

Outra estratégia, considerada inovadora no Fome Zero, foi o Programa Cisternas implantado inicialmente no semiárido brasileiro, região de seca, onde as chuvas se concentram em apenas 4 meses do ano, e que apresenta os indicadores sociais mais baixos do país. O programa consiste na implantação de tecnologias populares, simples e de baixo custo, para a captação de água da chuva para o consumo humano, combinada ao processo de formação para a convivência com o semiárido. Até meados de 2014 já haviam sido construídas mais de 1 milhões de cisternas no Brasil.

Também preconizada pelo Fome Zero é o Programa foi a criação do Programa Segunda Água, que objetiva viabilizar a produção de alimentos por meio da construção de equipamentos de captação de água, que permitem o cultivo de hortas e a criação de pequenos e médios animais.

$\mathrm{Na}$ área da saúde, as ações se voltaram principalmente para a prestação de serviços básicos e acompanhamento das condicionalidades do Programa Bolsa 
Família, incluindo a promoção da alimentação saudável, a vigilância alimentar e nutricional e a oferta universal dos programas de suplementação de ferro e vitamina A em postos de saúde.

\section{Fortalecimento da Agricultura Familiar}

Até meados de 1990, a política agrícola estava voltada quase exclusivamente ao agronegócio empresarial. Em meados de 1990, o Estado passa a reconhecer as demandas do movimento organizado de agricultores familiares, culminando com a instituição do Programa Nacional de Fortalecimento da Agricultura Familiar - PRONAF.

De acordo com o Censo Agropecuário do $\mathrm{IBGE}^{49}$, os estabelecimentos da agricultura familiar ${ }^{50}$ correspondem a $84,4 \%$ do total de estabelecimentos agropecuários, ocupam $1 / 4$ da área total e absorvem $75 \%$ da mão de obra ocupada na agropecuária. São também responsáveis pela maior parte da produção de alimentos voltada para o mercado interno. Produzem $77 \%$ do feijão preto, $87 \%$ da mandioca e $50 \%$ das aves, produtos estes que estão na base da cultura alimentar nacional.

A partir do Fome Zero, a agricultura familiar passa a ser reconhecida pelo papel que ocupa no abastecimento alimentar interno e pela sua capacidade de resposta para a garantia da soberania alimentar e a manutenção do preço dos alimentos, mesmo em períodos de crises globais que elevam os preços das commodities alimentares $^{51}$. As políticas voltadas à agricultura familiar passam também a ser valorizadas por sua capacidade de inclusão produtiva e geração de

\footnotetext{
${ }^{49}$ Censo do ano de 2000.

${ }^{50}$ Entende-se por estabelecimento de agricultura familiar, aquele em que o cultivo da terra realizado por pequenos proprietários rurais, tendo como mão-de-obra essencialmente o núcleo familiar, em contraste com a agricultura patronal - que utiliza trabalhadores contratados, fixos ou temporários, em propriedades médias ou grandes.

51 Commodities (significa mercadoria em inglês) pode ser definido como mercadorias, principalmente minérios e gêneros agrícolas, que são produzidos em larga escala e comercializados em nível mundial. As commodities são negociadas em bolsas mercadorias, portanto seus preços são definidos em nível global, pelo mercado internacional. As commodities são produzidas por diferentes produtores e possuem características uniformes. Geralmente, são produtos que podem ser estocados por um determinado período de tempo sem que haja perda de qualidade. As commodities também se caracterizam por não ter passado por processo industrial, ou seja, são geralmente matérias-primas.
} 
renda para as famílias que vivem no campo, abrangendo 4,4 milhões de estabelecimentos rurais familiares, dos quais 2,2 milhões de famílias pobres.

\section{Geração de Renda}

$\mathrm{Na}$ concepção original do Fome Zero, havia um conjunto de ações que eram categorizadas como "emergenciais", aquelas voltadas mais diretamente à ampliação das condições de acesso à alimentação, e também ações consideradas "estruturais", voltadas para a transformação das bases geradoras da insegurança alimentar. Nesta última categoria enquadram-se as ações de geração de renda.

E, correspondendo aos anseios dos movimentos sociais por uma economia justa e sustentável, o Governo Federal criou em 2003 a Secretaria Nacional de Economia Solidária (SENAES) no Ministério do Trabalho e Emprego, bem como o Conselho Nacional de Economia Solidária (CNES). Este órgão é formado por 56 entidades e tem uma função consultiva e propositiva entre setores do governo e da sociedade civil que atuam em prol da economia solidária.

Lançado em 2004, o Programa Economia Solidária em Desenvolvimento tem por finalidade promover o fortalecimento e a divulgação da economia solidária mediante políticas integradas, visando ao desenvolvimento por meio da geração de trabalho e renda com inclusão social. Entende-se por economia solidária o conjunto de atividades econômicas de produção, distribuição, consumo, poupança e crédito, organizado sob a forma de autogestão. Como alternativa ao mercado capitalista, a organização do trabalho se dá através de cooperativas, como instrumento de união dos esforços e capacidades, bem como de propriedade coletiva de bens, partilha dos resultados e responsabilidade solidária. O Programa Economia Solidária em Desenvolvimento está organizado em quatro áreas de intervenção:

- Acesso a conhecimentos: Formação, Incubação e Assessoramento Técnico;

- Organização da Produção e Comercialização Solidária;

- Fortalecimento das Finanças Solidárias e Acesso ao Crédito;

- Fortalecimento Institucional da Economia Solidária. 


\section{Articulação, Mobilização e Controle Social}

Uma das primeiras medidas tomadas, logo que lançado o Fome Zero, foi a recriação do Conselho Nacional de Segurança Alimentar e Nutricional CONSEA. Formado por 59 conselheiros, sendo 19 ministros de Estado e 38 representantes da sociedade civil, sua natureza é consultiva, mobilizadora e de assessoramento. Com estes instrumentos, o Conselho vem transformando o Fome Zero, originalmente uma política estratégica de um determinado governo, em uma política de Estado, por meio, principalmente, da promulgação da Lei Orgânica de Segurança Alimentar e Nutricional (LOSAN), em 2006, e da instituição da Política Nacional de Segurança Alimentar e Nutricional com o decreto $\mathrm{n}^{\mathbf{0}}$ 7.272, de 25 de agosto de 2010.

Para promover a mobilização e participação da sociedade civil, o governo criou inicialmente o Setor de Mobilização Social do Programa Fome Zero, que tinha como papel envolver o maior número possível de pessoas e instituições dispostas a colaborarem nesta grande tarefa de erradicação da fome no Brasil. Esta ação se deu em duas frentes principais, a primeira buscava estimular a responsabilidade social, o compromisso e doação das empresas e a segunda, buscava mobilizar a sociedade, através da educação popular.

Ao longo dos anos, apenas a segunda linha de atuação se consolidou, através principalmente da Rede de Educação Cidadã - RECID, apesar de que muitas empresas, originalmente estimuladas pelo Fome Zero, seguiram, de forma autônoma, realizando atividades de responsabilidade social e promoção da cidadania.

Em 2007, colocou como uma de suas prioridades a formação e o fortalecimento dos conselhos estaduais e municipais de Segurança Alimentar e Nutricional, de forma a qualificar a participação social dos atores sociais nestes espaços. Entre 2003 e 2010, a RECID envolveu cerca de 300.000 pessoas em processo de formação e capacitação para os direitos sociais, em especial o direito humano à alimentação adequada (Caisan, 2011).

O cartão alimentação era uma das ações específicas de promoção da segurança alimentar prevista pelo Programa Fome Zero. Criado em fevereiro de 
2003, pela Medida Provisória $\mathrm{n}^{\circ} 108$ e, posteriormente convertida na Lei $\mathrm{n}^{\circ}$ 10.689 de 13 de junho de 2003 e regulamentado pelo Decreto ${ }^{\circ} 4.675$, de 16 de abril de 2003. Sua implantação previa a adoção, em parceria com os demais entes federados, de ações específicas (educação alimentar, orientações de higiene e saúde, por exemplo) e estruturais (reforma agrária, saneamento básico, irrigação, habitação, dentre outras) para a superação da insegurança alimentar. O benefício era de $\mathrm{R} \$ 50,00$, dirigido às famílias em situação de insegurança alimentar com, com renda mensal inferior a $1 / 2$ salário mínimo per capita.

\section{5. \\ Programa Bolsa Família: algumas considerações sobre o desenho operacional e objetivos}

Criado em 2004, o Programa teve por finalidade a unificação dos procedimentos de gestão e execução de quatro programas federais: o Programa Nacional de Renda Mínima vinculada a Execução, o Bolsa Escola; o Programa Nacional de Renda Mínima vinculada à Sáude - Bolsa Alimentação; Programa Auxílio-Gás e o Programa Nacional de Acesso à Alimentação -PNAA.

O PBF foi criado com a justificativa de combater a miséria. A exclusão social, além de promover a emancipação das famílias mais pobres, sendo lançado como um programa de combate à fome e a pobreza, tornando a Política de Renda Mínima do Governo Federal, de caráter não contributivo, destinado ao público da assistência social, com condicionalides e focalizado, ou seja destinado ás famílias em situação de pobreza ${ }^{52}$ ( renda per capita mensal de $\mathrm{R} \$ 70,01$ até $\mathrm{R} \$ 140,00$ ) e em situação de extrema pobreza ( renda per capita mensal até R \$ 70,00).

O principal objetivo do Programa é a inclusão social das famílias em situação de pobreza e extrema pobreza, baseando-se na articulação de três fundamentos: i) a curto prazo, o alívio imediato da pobreza por meio da transferência de renda; ii) a médio prazo, a ruptura do ciclo intergeracional da pobreza, por meio do acesso aos serviços básicos de saúde, educação e assistência

\footnotetext{
${ }^{52}$ Em 2013 este valor foi atualizado da seguinte maneira: extrema pobreza, até R $\$ 77,00$ e pobreza de $\mathrm{R} \$ 77,01$ até $\mathrm{R} \$ 154,00$.
} 
social, que se materializa no cumprimento das condicionalidades do Programa, ${ }^{53}$ iii) a longo prazo, o desenvolvimento integral das famílias.

Para unificar as ações de Assistência Social e aquelas relacionadas ao Fome Zero no Programa Bolsa Família, houve a necessidade de uma reorganização e modernização das instituições governamentais, para que os programas fossem executados e administrados de forma integrada e descentralizada, como prevê o sistema federal brasileiro. Dentre estas reformas institucionais, podemos citar a criação do Ministério do Desenvolvimento Social

Combate à Fome (MDS), em 2004, e sua regulamentação organizacional em 2010. ${ }^{54}$

Por motivo da descentralização política, oriunda do sistema federativo, a execução e gestão do PBF exigem a cooperação entre as três esferas do poder público. Por isso, os 5.570 municípios brasileiros passaram por um processo de adesão regulado por duas Portarias ( $\mathrm{N}^{\mathrm{o}} 246$ de 2005 e No 148 de 2006) do MDS, através de um “Termo de Adesão ao Programa Bolsa Família e ao Cadastro Único de Programas Sociais".

As portarias estabelecem as normas, critérios e procedimentos para o apoio à gestão do PBF e do Cadastro Único no âmbito dos municípios. Inicialmente estabeleceu-se uma meta de 11 milhões de famílias a serem beneficiadas pelo programa. Esta meta foi definida com base no número de famílias cuja renda domiciliar per capita encontrava-se abaixo da linha de pobreza estabelecida pelo programa (R \$ 100 em 2003), de acordo com a Pesquisa Nacional por Amostra de Domicílios (PNAD) de 2001 e 2002. A partir de estimativas de pobreza, foram

${ }^{53}$ Estudos do IPEA e FGV comprovam que no Brasil a pobreza se reproduz intergeracionalmente. Logo, se os pais não tiveram acesso à educação e a saúde, por exemplo, os filhos terão maiores dificuldades em tê-la. O PBF tem como objetivo romper este ciclo, buscando um patamar prioritário de acesso aos serviços básicos por parte destas famílias.

${ }^{54}$ A estrutura do MDS passou a ser constituída pelas seguintes secretarias: Secretaria Nacional de Assistência Social (SNAS), Secretaria Nacional de Renda de Cidadania (Senarc); Secretaria Nacional de Segurança Alimentar e Nutricional (Sesan), Secretaria Extraordinária de Superação da Extrema Pobreza (Sesep). Esta é responsável pela coordenação das ações e gestão do Plano Brasil sem Miséria. A Secretaria articula e mobiliza os esforços do governo federal, estados e municípios para a superação da extrema pobreza. A Senarc é a secretaria responsável pelo Programa Bolsa Família. As suas principais atribuições são a coordenação interministerial e intersetorial e a gestão da operacionalização do Programa Bolsa Família. Algumas de suas atividades são: a concessão e o pagamento de benefícios, a gestão do Cadastramento Único do Governo Federal, a supervisão do cumprimento das condicionalidades e da oferta dos programas complementares, em articulação com os Ministérios setoriais e demais entes federados, e o acompanhamento e a fiscalização de sua execução. 
fixadas metas de atendimento para cada um dos 5.570 municípios, que, a partir do desenho de gestão do programa, ficaram responsáveis pelo cadastramento de novas famílias.

Desde sua criação, o programa passou por significativa ampliação e uma série de aperfeiçoamentos do ponto de vista de seu escopo, institucionalização e gestão. Em janeiro de 2015, o programa atendia mais de 14 milhões de famílias, o que corresponde a aproximadamente 58 milhões de pessoas, ou $28 \%$ da população brasileira, com um repasse de mais de $\mathrm{R} \$ 2$ bilhões de reais mensais, de acordo com o MDS.

\section{Elegebilidade dos Beneficiários}

O Programa Bolsa Família está voltado às famílias que se encontram em situação de pobreza (renda per capita mensal de $\mathrm{R} \$ 77,01$ até $\mathrm{R} \$ 154,00$ ) ou extrema pobreza (renda per capita mensal de até $\mathrm{R} \$$ 77,00). A definição de família adotada pelo programa é a unidade familiar, eventualmente ampliada por outros indivíduos que com ela possuam ter laço de parentesco ou de afinidade, que forme um grupo doméstico, vivendo sob um mesmo teto e que se mantém pela contribuição de seus membros (Lei no 10.836/2004).

O critério de elegibilidade do Programa Bolsa Família é definido a partir de duas linhas de corte baseadas na renda familiar per capita, de acordo com a linha de pobreza e a linha de extrema pobreza, conforme vimos anteriormente. O PBF apresenta como uma de suas características a unidade beneficiária do PBF, que é referenciado no grupo familiar, representado preferencialmente pela mulher. O benefício é pago por meio de cartão magnético fornecido pela CAIXA, que tem a função de ser o agente pagador e operador do Programa.

O valor do benefício pago à família é de acordo com a renda per capita mensal, autodeclarada no Cadastro Único. Famílias que estão na faixa de extrema pobreza recebem no mínimo $\mathrm{R} \$ 77,00$ e, no máximo, $\mathrm{R} \$ 336,00$. Famílias em situação de pobreza recebem no mínimo $\mathrm{R} \$ 35,00$ e, no máximo, $\mathrm{R} \$ 236,00$. A partir dezembro de 2012 foi criação do benefício extraordinário de superação da 
extrema pobreza ${ }^{55}$, onde a família recebe o complemento a fim de obter a renda mínima de $\mathrm{R}$ \$ 70,00 per capita, mesmo após o recebimento de outros benefícios.

Além dos limites no método de identificação da pobreza, o programa não possui regras de indexação formal para os benefícios do PBF. Porém, desde 2004, o PBF já passou por três reajustes, quando os valores foram corrigidos com base no Índice Nacional de Preços ao Consumidor -INPC ${ }^{56}$. Além dos reajustes, foram também ampliados os benefícios variáveis, como por exemplo a inclusão de benefício jovem e ampliação do número de filhos, de três para cinco. Tais alterações nos critérios de composição da renda transferida levaram também a uma significativa ampliação do benefício, principalmente às famílias mais numerosas que, em muitos casos, são também as mais vulneráveis.

\section{Condicionalidades do Programa}

As condicionalidades do Programa se expressam em compromissos na área de saúde, educação e assistência social, conforme podemos observar na figura abaixo.

55 O Benefício para Superação da Extrema Pobreza - BSP, lançado em 2012 no âmbito da Ação Brasil Carinhoso, é um dos benefícios que compõem o Programa Bolsa Família, assim como o Benefício Básico, Benefício Variável e o Benefício Variável Jovem, entre outros. O BSP tem como objetivo garantir renda mínima de R\$ 77,00 por pessoa da família beneficiária do PBF que, mesmo recebendo outros benefícios do Programa (Básico, Variável, Benefício Variável Jovem, entre outros), permanecem em situação de extrema pobreza ( MDS, 2012).

${ }^{56}$ É o índice que mede a inflação da cesta de consumo de famílias cuja renda situa-se entre um e oito salários mínimos. 


\begin{tabular}{|c|c|}
\hline SAÚDE & EDUCAÇĀO \\
\hline $\begin{array}{l}\text { Para gestantes e nutrizes: } \\
\text { - Inscrever-se no pré-natal } \\
\text { e comparecer as consultas na } \\
\text { unidade de saúde mais próxima da } \\
\text { residência, portando o cartáo da } \\
\text { gestante, de acordo com o calendário } \\
\text { mínimo do Ministério da Saúde; } \\
\text { - Participar das atividades } \\
\text { educativas ofertadas pelas equipes de } \\
\text { saúde sobre aleitamento materno e } \\
\text { promoção da alimentação saudável. } \\
\text { Para os responsáveis pelas } \\
\text { crianças menores de sete anos: } \\
\text { - Levar a criança as unidades } \\
\text { de saúde ou aos locais de } \\
\text { vacinaçáo e manter atualizado o } \\
\text { calendário de imunizaçáo, conforme } \\
\text { diretrizes do Ministério da Saúde; } \\
\text { - Levar a criança às unidades } \\
\text { de saúde, portando o cartáo de } \\
\text { saúde da criança, para a realização } \\
\text { do acompanhamento do estado } \\
\text { nutricional e do desenvolvimento e } \\
\text { outras açóes, conforme calendário } \\
\text { mínimo do Ministério da Saúde. }\end{array}$ & $\begin{array}{l}\text { - Matricular as crianças e } \\
\text { adolescentes de } 6 \text { a } 15 \text { anos em } \\
\text { estabelecimento regular de ensino; } \\
\text { - Garantir a frequência escolar de } \\
\text { no mínimo } 85 \% \text { da carga horária mensal } \\
\text { do ano letivo, informando sempre à } \\
\text { escola em casos de impossibilidade } \\
\text { do comparecimento do aluno à aula } \\
\text { e apresentando a devida justificativa; } \\
\text { - Informar de imediato ao setor } \\
\text { responsável pelo PBF no municipio, } \\
\text { sempre que ocorrer mudança de } \\
\text { escola e de série dos dependentes } \\
\text { de } 6 \text { a } 15 \text { anos, para que seja } \\
\text { viabilizado e garantido o efetivo } \\
\text { acompanhamento da frequência escolar. }\end{array}$ \\
\hline
\end{tabular}

Quadro 3- Condicionalidades do Programa Bolsa Família.

Fonte: MDS, elaboração da autora.

As condicionalidades se constituem em "um sistema de indução que busca afetar o comportamento dos membros adultos das famílias vulneráveis, por meio da associação de um prêmio financeiro a decisões consideradas socialmente ótimas, com o investimento em saúde nas próximas gerações” (MDS, 2013).

Há diferentes visões na sociedade brasileira no que se refere à exigência de condicionalidades. Na perspectiva do Ministério do Desenvolvimento Social e Combate à Fome, as condicionalidades contribuem no acesso às políticas de saúde e educação e para a superação da pobreza, por meio de uma rede intersetorial constituída para esta finalidade. Resultados apresentados pela avaliação de impacto do Bolsa Família (AIBF), de 2009, mostram que a proporção de crianças beneficiadas pelo PBF que se mantém na escola até os 14 anos, comparada aos não beneficiários, é maior, assim como as taxas de progressão escolar. 
Para o Governo Federal, a construção de uma rede e de uma sistemática de acompanhamento das condicionalidades do PBF é uma responsabilidade compartilhada entre a família, que deve buscar o exercício de seus direitos de cidadania, e o poder público, que deve ofertar os serviços em quantidade e qualidade adequadas às necessidades desta população.

Neste sentido, o acompanhamento das condicionalidades funciona como um instrumento efetivo de monitoramento do acesso das famílias aos serviços de assistência social, educação e saúde.

O acompanhamento das condicionalidades, por parte do poder público, depende de uma rede intersetorial de acompanhamento, da qual participam as áreas de saúde, educação e assistência social, nas três esferas de governo, muitas vezes organizadas institucionalmente enquanto "comitês gestores intersetoriais do PBF”, e de um Sistema Integrado de Gestão das Condicionalidades, constituído por sistemas informacionais para a inclusão e acompanhamento dos dados.

\section{Cadastro Único}

Foi por meio do Cadastro Único e mais especificamente a partir do esforço de consolidação do Programa Bolsa Família que, pela primeira vez, se coletou um conjunto consistente e constantemente atualizado de informações sobre as famílias com a finalidade de integração da política social. O Cadastro Único para Programas Sociais (Cadastro Único) foi criado em 2001, e desde então vem sendo aperfeiçoado enquanto o principal instrumento público nacional para o cadastramento e manutenção de informações atualizadas das famílias brasileiras em situação de extrema pobreza.

O cadastro, utilizado pelas três esferas de governo, pretende identificar potenciais beneficiários dos programas sociais, buscando proporcionar melhor focalização e evitar a sobreposição de programas a uma mesma família. Cabe aos municípios cadastrar as famílias, o que ocorre principalmente através das escolas, dos Centros de Referência da Assistência Social (CRAS) e, mais recentemente, dos mecanismos de "busca ativa", estratégias direcionadas a determinados segmentos mais vulneráveis e distanciados da rede de serviços públicos, como os povos indígenas e a população de rua. 
Cabe também à esfera municipal, em geral às Secretarias de Assistência Social, a atualização dos registros e o zelo pela fidedignidade das informações fornecidas. Para realizar o cadastro, os municípios contam com um questionário padrão que contém, além de nome e endereço, uma ampla variedade de informações sobre as condições de vida das famílias, organizadas em seis dimensões: vulnerabilidades, acesso ao conhecimento, acesso ao trabalho, disponibilidade de recursos, desenvolvimento infantil e condições habitacionais.

Dada a grande variedade de informações disponíveis e o elevado grau de cobertura do Cadastro Único, este instrumento é ainda subutilizado, pois ele permite traçar o perfil da pobreza, realizar diagnósticos e identificar as principais carências de cada município, o que possibilitaria um melhor direcionamento dos recursos públicos e o aumento da eficiência da política social.

\section{Gestão Descentralizada, Controle Social e Financiamento}

A execução e gestão do Programa Bolsa Família acontecem de forma descentralizada, por meio da conjugação de esforços entre governo federal, estados e municípios, observadas a intersetorialidade, a participação e o controle social. O Governo Federal, por intermédio do MDS, é responsável pelo financiamento, desenho institucional, coordenação e monitoramento do programa. Os ministérios da Saúde e Educação participam também, na medida em que são responsáveis pela oferta de serviços e acompanhamento das condicionalidades.

Os municípios têm papel fundamental, cuja atribuição mais importante é o recolhimento das informações que compõem o Cadastro Único, o que significa que são os agentes municipais que "decidem" ${ }^{57}$ quem são os potenciais beneficiários.

Dado o papel central exercido pela esfera municipal, a partir de 2006, o governo federal passou a apoiar financeiramente a gestão municipal por meio de repasses mensais, calculados com base no número de famílias beneficiárias e no Índice de Gestão Descentralizada (IGD), que mede a eficiência do município no cadastramento e acompanhamento das condicionalidades. 
Os recursos transferidos são utilizados localmente em atividades relacionadas ao cadastramento, acompanhamento de condicionalidades, implementação de programas complementares determinados a partir da demanda das famílias, fiscalização e controle social.

O processo de gestão do Programa é compartilhado entre os entes federados, que implica os princípios da execução intersetorial e descentralizada, mediante a responsabilidade solidária das três esferas do governo para a redução da pobreza e reconhecem que o estabelecimento de seus componentes dependem do estabelecimento de cooperação intergovernamental, com atribuições articuladas e complementares, tendo em vista a abrangência territorial do Programa (5.570 municípios , 26 estados e o Distrito Federal) e sua escala ( número de famílias beneficiárias).

Além da Gestão descentralizada e compartilhada o PBF tem como característica a previsão forte atuação do Controle Social. Cabe destacar que a construção das políticas sociais no Brasil, principalmente a partir da Constituição Federal de 1988, tem sido marcada pela instituição de mecanismos e espaços de participação da sociedade civil organizada na formulação, monitoramento e controle social das políticas públicas.

No que se refere ao Programa Bolsa Família, o controle social é entendido como "o acompanhamento efetivo da sociedade civil na gestão do PBF como contribuição para uma maior transparência das ações do Estado e garantia de acesso das famílias mais vulneráveis ao Programa". É operacionalizado por meio das Instâncias de Controle Social (ICS), que funcionam, na maior parte dos casos, através de conselhos de políticas públicas anteriormente existentes na esfera municipal, tais como os Conselhos Municipais de Assistência Social, Saúde, Educação, e Segurança Alimentar e Nutricional. Segue abaixo quadro demonstrativo das atribuições dos Conselhos de Controle Social do Programa Bolsa Família.

\footnotetext{
${ }^{57}$ No sentido de incluir as famílias no Cadastro Único, estamos nos referindo a este sentido, visto que a concessão do benefício é efetuada por meio de um processo sistêmico, não manual.
} 
ATRIBUÇÓES DOS CONSELHOS DE CONTROLE SOCIAL DO PROGRAMA BOLSA FAMILAA:

I - acompanhar, avaliar e subsidiar a fiscalizaçâo da execuçáo do PBF;

II - acompanhar e estimular a integraçâo e a oferta de outras politicas püblicas sociais para as familias beneficiarias do PBF;

III - acompanhar a oferta por parte dos governos locais dos serviços necessários para a realizaçâo das condicionalidades;

IV - estimular a participaçao comunitaria no controle da execução do PBF.

Quadro 4- Atribuições da Instância de Controle Social no Programa Bolsa Família. Fonte: Elaboração da autora, MDS.

No que se refere especificamente ao financiamento do Programa Bolsa Família, o artigo $6^{\circ}$ da Lei $n^{\circ} 10.836 / 2004$, que cria o Programa Bolsa Família, determina que as despesas do programa correrão à conta das dotações alocadas nos programas federais de transferência de renda e no Cadastramento Único, bem como de outras dotações do Orçamento da Seguridade Social da União que vierem a ser consignadas ao Programa. Diz ainda que o o Poder Executivo deverá compatibilizar a quantidade de beneficiários do Programa Bolsa Família com as dotações orçamentárias existentes.

A maior parte do orçamento destinado ao Programa Bolsa Família está alocada em dotação orçamentária própria, no Ministério do Desenvolvimento Social e Combate à Fome (MDS). O Ministério da Saúde também destina ao PBF recursos provenientes de seu Fundo Nacional de Saúde, voltados ao financiamento de despesas relacionadas ao cumprimento das condicionalidades.

De acordo com estudos do International Poverty Center, ligado ao Programa das Nações Unidas para o Desenvolvimento (PNUD), de 2008, há uma participação crescente dos recursos destinados ao financiamento do PBF no orçamento da Seguridade Social. Em 2004, os recursos do PBF representavam 1,3\% do orçamento destinado à Seguridade Social. Em 2007, este percentual chegou a 2,7\%. Cabe informar que a maior parte dos recursos da Seguridade Social é destinada aos benefícios de origem contributiva, ou seja, para o financiamento da Previdência Social. O Orçamento Geral da União de 2011 destinou, até o dia 31 de dezembro de 2011, 22,01\% para a Previdência Social, 4,07\% para a Saúde e 2,85\% para a Assistência Social, de acordo com o MDS.

Observe-se que 3\% foram destinados à Educação, enquanto os gastos para o pagamento de juros e amortizações da dívida pública federal atingiram $45 \%$ dos 
recursos do orçamento geral, ou seja, o montante de 708 bilhões de reais. Conforme dados do MDS, o Programa Bolsa Família teve seu orçamento significativamente ampliado entre 2003, ano de sua criação, e 2014, passando de $\mathrm{R}$ \$ 3,2 bilhões para R \$ 20 bilhões. Cabe destacar que, em 2014, o investimento público no PBF representava apenas $0,5 \%$ do Produto Interno Bruto (PIB) nacional.

Para os gestores do programa trata-se de um "investimento na movimentação da economia local”. Partem ainda do pressuposto que quem paga pelo programa é a própria sociedade, inclusive os segmentos diretamente beneficiados pelo programa, uma vez que parte dos dispêndios do governo com o PBF retorna por meio dos impostos arrecadados com o aquecimento do mercado de massas estimulado pelo próprio programa.

\section{6. Plano Brasil Sem Miséria: garantia de proteção e promoção social para a redução da pobreza no Brasil?}

$\mathrm{Na}$ última década, o Brasil alcançou avanços em termos de redução da pobreza, estimando-se que 28 milhões de pessoas saíram da pobreza de acordo com as informações do Governo Federal baseados em estudos da FGV e do IPEA.

Este resultado deve-se a um conjunto de fatores, que vão desde a recuperação do salário mínimo, passando pela crescente incorporação de trabalhadores no mercado formal de trabalho, com o aumento do número de empregos até a consolidação do PBF. Ainda de acordo com os referidos estudos, o crescimento da renda dos mais pobres aumentou 20\% no período de 2003-2009, sendo $6 \%$ do desse aumento provenientes do acesso ao trabalho formal.

Mesmo com os avanços registrados, de acordo com o IBGE (Censo/2010), 6,8 milhões de pessoas viviam em domicílios sem qualquer rendimento. Deste total, foram identificadas 4,8 milhões de pessoas com o perfil de extrema pobreza $^{58}$. Se a elas forem somadas as 11,4 milhões de pessoas com rendimento

\footnotetext{
${ }^{58} \mathrm{O}$ perfil de extrema pobreza, além do critério de renda, considera os domicílios sem banheiro de
} uso exclusivo; ou, sem ligação com rede geral de esgoto ou pluvial e que não tinham fossa séptica; 
médio per capita entre $R \$ 1,00$ e $R \$ 70,00$, que também possuem o perfil de extrema pobreza, atingisse o total estimado de 16,2 milhões de pessoas nesta condição.

Também, conforme os dados do IBGE, projeta-se que 8,5\% dos domicílios brasileiros encontram-se na condição de pobreza extrema. A maioria das pessoas nessa condição mora em áreas urbanas (53\%). No entanto, os $47 \%$ que moram em áreas rurais representam $1 / 4$ da população rural, proporção significativamente maior do que os $5 \%$ da população urbana em extrema pobreza.

Chama a atenção, de acordo com o IBGE, a maior presença de mulheres nessa situação nas áreas urbanas e maior participação masculina nas áreas rurais. Em relação à escolaridade, $26 \%$ das pessoas em extrema pobreza são analfabetas. Os negros (pretos ou pardos) correspondem a $71 \%$ da população extremamente pobre. Com relação a concentração regional da extrema pobreza, do total, 59\% estão na região Nordeste, correspondendo a 9,6 milhões de pessoas. Na distribuição etária, destaca-se o fato de que $51 \%$ têm até 19 anos de idade e $40 \%$ até 14 anos de idade.

O cenário apresentado anteriormente tem demonstrando que as políticas públicas implementadas não foram suficientes e mostraram-se de difícil acesso para as camadas mais pobres da população, sendo incapazes de reverter a situação de extrema pobreza de muito brasileiros. E neste contexto, o governo da Presidente Dilma Rousseff, ciente da limitação da política aplicada, apresenta o Plano Brasil Sem Miséria (PBSM) em junho de 2011, com o objetivo audacioso de erradicar a extrema pobreza monetária até 2014.

Ao lançar o Plano, o governo federal reconheceu como um dos maiores desafios a enfrentar, dentro do objetivo de erradicação da extrema pobreza, o fato de que a mesma se caracteriza pela sua multidimensionalidade, exigindo assim uma ação articulada intersetorialmente. Apesar de o MDS desempenhar o papel principal para o cumprimento deste objetivo, compreende-se que somente será à rede geral de distribuição de água e sem poço ou nascente na propriedade; ou, sem energia elétrica; ou, com pelo menos um morador de 15 anos ou mais de idade analfabeto; ou, com pelo menos três moradores de até 14 anos de idade analfabetos; ou, com pelo menos um morador de 65 anos ou mais de idade, analfabeto. 
possível a execução efetiva do Plano mediante a ação integrada de um conjunto de ministérios, secretarias e órgãos de governo.

\section{Eixos de atuação do Plano Brasil Sem Miséria}

Além das premissas que definem sua forma de atuação Inter setorial, mediante a pobreza multisetorial, o Plano prevê três frentes de ações que deverão ser executadas de forma integrada:

1) Elevação da renda familiar per capita daquelas famílias que se encontram em situação de extrema pobreza;

2) Acesso dos mais pobres aos serviços públicos, as ações de cidadania e de bem-estar social;

3) Execução de medidas que visam ampliar o acesso às oportunidades de ocupação e renda por meio de ações de inclusão produtiva nos meios rural e urbano.

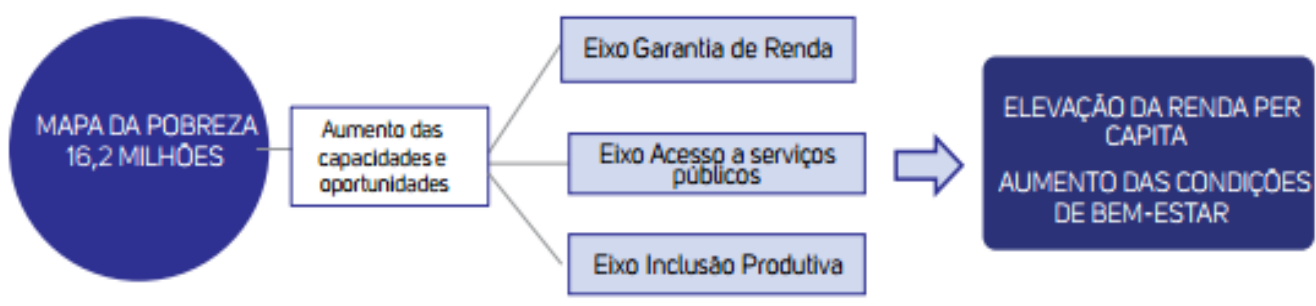

Figura 2- Eixos de atuação Plano Brasil Sem Miséria.

Fonte: MDS, Caderno Brasil Sem Miséria.

Segue a seguir a descrição do conjunto inicial de instrumentos adotados para dar sustentação a cada uma das frentes de atuação do Plano Brasil sem Miséria. 


\section{Elevação da Renda Familiar}

\section{Busca Ativa para inclusão no Cadastro Único das Políticas Sociais}

Trata-se de ações voltadas para incluir no Cadastro Único as famílias que vivem fora da rede de proteção e promoção social. Prevê-se a realização de mutirões e campanhas de busca, o cruzamento de cadastros já existentes e o incentivo ao envolvimento e qualificação dos gestores públicos no atendimento à população extremamente pobre.

Nos municípios com baixa cobertura ${ }^{59}$ no Programa Bolsa Família deverá ocorrer um esforço adicional de cadastramento de segmentos específicos da população, a ser feito por meio dos Centros de Referência de Assistência Social, presentes atualmente em 4.720 municípios.

\section{Programa Bolsa Família}

Por meio do Plano, o objetivo é incluir mais de 800 mil novas famílias em situação de extrema pobreza no Bolsa Família. Foi também como parte da estratégia do Brasil sem Miséria que o MDS aumentou o limite de três para cinco filhos beneficiados pelo Programa, o que ampliou significativamente o valor total repassado às famílias e permitiu a inclusão no programa de 1,3 milhões de crianças e adolescentes até 15 anos. Mantiveram-se para estes as condicionalidades do Programa, como a obrigação de estarem frequentando a escola e com acompanhamento de saúde.

Há também a iniciativa no sentido de estimular os governos estaduais e municipais a complementar a renda transferida pelo governo federal. Alguns $\operatorname{estados}^{60}$ e municípios já aderiram a esta proposta e passaram a destinar orçamento próprio para o seu financiamento, como é o caso do PRSM por meio do Programa Renda Melhor. Outra nova estratégia adotada é a utilização do cartão do Bolsa Família para o pagamento de créditos referentes a novos

\footnotetext{
${ }^{59}$ Baixa cobertura de famílias cadastradas no Cadastro Único.

${ }^{60}$ Além do Plano do Rio de Janeiro, há mais 17 planos estaduais e o plano do DF.
} 
programas, como o pagamento de créditos de Fomento para o Meio Rural e o Bolsa Verde.

\section{Acesso a serviços públicos}

Em consonância com a segunda frente de atuação do Plano identifica-se a necessidade de ampliação da oferta de serviços públicos nas áreas aonde há concentração de pobreza, de forma a garantir o acesso a programas, conforme podemos observar na figura a seguir.

\begin{tabular}{|c|c|}
\hline PROGRAMA & DESCRIÇĀO \\
\hline $\begin{array}{l}\text { Saúde da Família } \\
\text { (Ministério da Saúde) }\end{array}$ & $\begin{array}{l}\text { Prioriza as ações de prevenção, promoção e recuperação } \\
\text { da saúde das pessoas, de forma integral e contínua. O } \\
\text { atendimento é prestado na unidade básica de saúde ou } \\
\text { no domicílio, pelos profissionais (médicos, enfermeiros, } \\
\text { auxiliares de enfermagem e agentes comunitários de saúde) } \\
\text { que compõem as equipes de Saúde da Família. }\end{array}$ \\
\hline $\begin{array}{l}\text { Brasil Sorridente } \\
\text { (Ministério da Saúde) }\end{array}$ & $\begin{array}{l}\text { Reúne uma série de ações em saúde bucal, voltadas para } \\
\text { cidadãos de todas as idades. }\end{array}$ \\
\hline $\begin{array}{l}\text { Olhar Brasil } \\
\text { (Ministério da Saúde) }\end{array}$ & $\begin{array}{l}\text { Tem como objetivo Identificar problemas visuais, em alunos } \\
\text { matriculados na rede pública de ensino fundamental (1ª a } \\
\text { 8a série), no programa "Brasil Alfabetizado" do MEC e na } \\
\text { população acima de } 60 \text { anos de idade. }\end{array}$ \\
\hline $\begin{array}{c}\text { Brasil Alfabetizado } \\
\text { (Ministério da } \\
\text { Educação) }\end{array}$ & $\begin{array}{l}\text { É desenvolvido em todo o território nacional e voltado para } \\
\text { a alfabetização de jovens, adultos e idosos. }\end{array}$ \\
\hline
\end{tabular}

Quadro 5- Descrição dos programas que compõem a estratégia de Acesso a Serviços Públicos do Plano Brasil Sem Miséria.

Fonte: MDS, 2011, Caderno do Plano Brasil Sem Miséria.

O Plano Brasil sem Miséria tem como premissa o reconhecimento de que as pessoas em situação de extrema pobreza têm maior dificuldade no acesso à rede de bens e serviços públicos, o que se constitui em um paradoxo, por ser justamente este o público prioritário da maior parte das ações. O Plano tem como objetivos adotar novas abordagens para melhorar o atendimento à população extremamente pobre, que deverão incorporar especial atenção à mobilização e 
qualificação de servidores públicos, nos três níveis de governo, para que possam exercer com efetividade e capacidade o acolhimento a esse público prioritário.

Os Centros de Referência da Assistência Social (CRAS), presentes em grande parte dos municípios brasileiros, serão utilizados como pontos de atendimento dos programas que fazem parte do Plano Brasil Sem Miséria. Afora os pontos já existentes, pretende-se que outros sejam criados de forma a ampliar o atendimento em todos os territórios em que há concentração de pobreza.

\section{Inclusão Produtiva}

As iniciativas voltadas para a inclusão produtiva dos extremamente pobres foram desenhadas especificamente para as realidades rural e urbana. Trata-se, sobretudo, da ampliação e adequação de políticas já existentes que buscariam: i) reforçar todos os mecanismos que já vinham sendo utilizados com sucesso no passado; ii) redesenhar 45aqueles que não vinham demonstrando grande efetividade; iii) introduzir novos programas e ações inovadoras, em particular em áreas estratégicas como a formação profissional e a assistência técnica personalizada aos agricultores familiares ${ }^{61}$.

No campo, onde se encontra $47 \%$ do público do Plano, a prioridade é aumentar a produção do agricultor através de orientação e assistência técnica, oferta de fomento, sementes e água. Segue abaixo figura que ilustra a estratégia de atuação adotada.

61 PAES de BARROS, Ricardo; MENDONÇA, Rosane e TSUKADA, Raquel. Portas de saída, inclusão produtiva e erradicação da extrema pobreza no Brasil. Brasília: SAE/PR, 2011. 


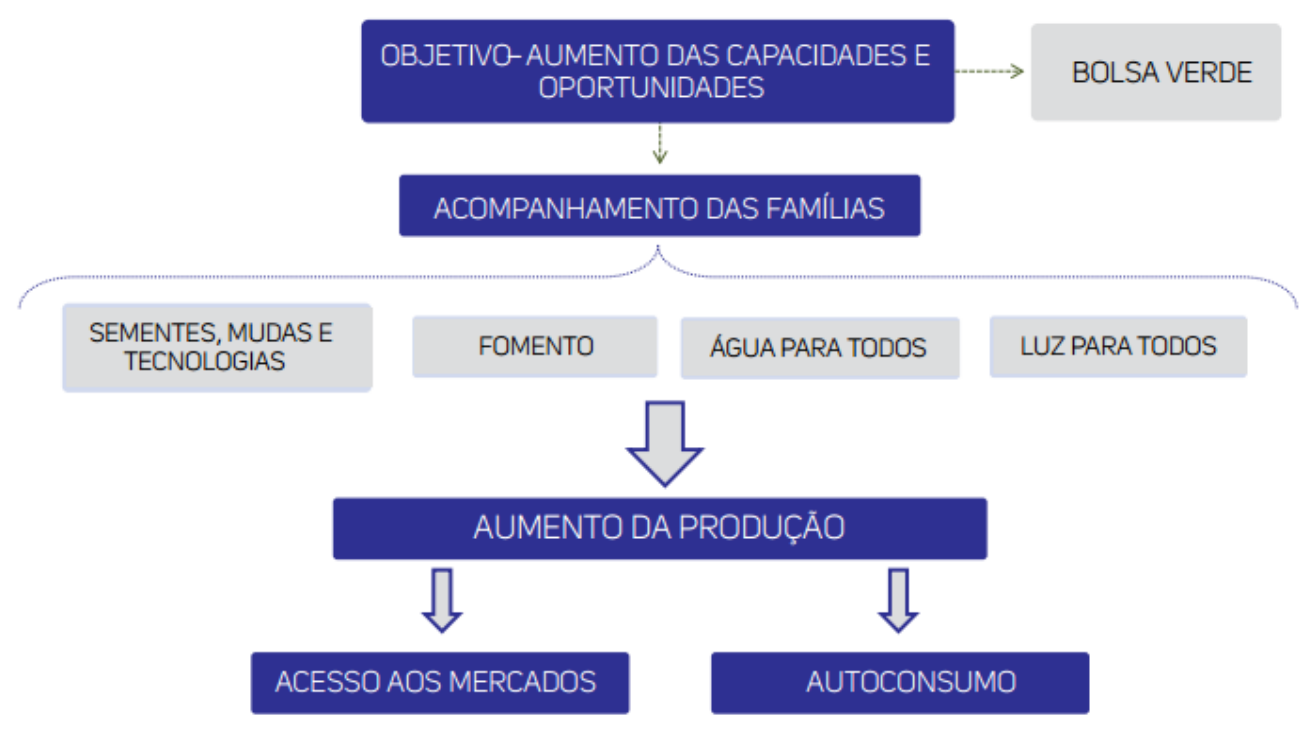

Figura 3- Inclusão Produtiva Rural.

Fonte: MDS 2011, Caderno Plano Brasil Sem Miséria.

Entre os programas e ações voltados à inclusão produtiva rural, destacamse as seguintes inovações:

- Oferta de crédito de fomento a fundo perdido a 250.000 famílias de agricultores familiares em situação de extrema pobreza, no valor de $\mathrm{R} \$ 2.400,00$, pagos em parcelas durante dois anos, por meio do cartão do Programa Bolsa Família. O crédito será voltado a aquisição de insumos e equipamentos;

- Distribuição gratuita de sementes e mudas para 253.000 famílias de agricultores familiares em situação de extrema pobreza;

- Instituição do programa Bolsa Verde, que irá transferir recursos financeiros na ordem de $\mathrm{R} \$ 300,00$ a cada trimestre por meio do cartão do Bolsa Família a famílias em situação de extrema pobreza para a conservação de ativos ambientais. Contemplará as famílias em situação de pobreza extrema que vivem ou trabalham em florestas nacionais, reservas extrativistas e de desenvolvimento sustentável federais e em projetos de assentamentos ambientalmente diferenciados.

As ações já existentes que foram adequadas e/ou ampliadas foram as seguintes:

- Oferta de assistência técnica combinada às estratégias anteriormente descritas, atuando diretamente junto às famílias, com acompanhamento continuado e individualizado, por equipes profissionais contratadas 
prioritariamente na região pelo Governo Federal. Cada grupo de mil famílias contará com um técnico de nível superior e dez técnicos de nível médio. Planejase garantir o emprego de tecnologias apropriadas a cada família em parceria com universidades e Embrapa. Ao mesmo tempo será estimulada a produção para autoconsumo;

- Ampliação do Programa Água para Todos, que visa à garantia do acesso à água para toda a população extremamente pobre, residente no meio rural. Dá prosseguimento à exitosa experiência do Programa Um Milhão de Cisternas ${ }^{62}$, no semiárido nordestino, com o chamado Programa Primeira Água, que projeta o atendimento de 750 mil famílias rurais, com a construção de cisternas e sistemas simplificados coletivos de acesso à água para consumo humano e o Programa Segunda Água, que pretende atender 600 mil famílias rurais com água para produção. Além disso, serão realizadas iniciativas de irrigação para pequenas propriedades;

- Ampliação ${ }^{63}$ do Programa de Aquisição de Alimentos (PAA) de 156 mil para 445 mil famílias de agricultores familiares atendidas nos próximos quatro anos, das quais 255 mil famílias encontram-se na condição da extrema pobreza (atualmente são 66 mil famílias desse contingente que acessam o PAA). Para a estratégia de viabilizar o acesso da agricultura familiar mais empobrecida aos mercados públicos e institucionais, pretende-se, por outro lado, ampliar as compras para instituições públicas e filantrópicas, incluindo no programa hospitais federais, universidades, presídios e creches. No que se refere aos mercados privados, incluem-se negociações com supermercados, empresas e restaurantes para que estes façam a aquisição de produtos da agricultura familiar de famílias que se encontram em condição de pobreza extrema;

- Ampliar o atendimento do Programa Luz para Todos, que teve grande êxito durante o governo do Presidente Lula e que visa a atender nos próximos quatro anos 257 mil famílias extremamente pobres estabelecidas no meio rural;

- Ações voltadas para os Assalariados Rurais, que estão entre os mais penalizados socialmente. Pretende-se incentivar a realização de acordos tripartites

\footnotetext{
${ }^{62}$ Até meados de 2014 já haviam sido construídas mais de um milhão de cisternas.

${ }^{63}$ O PAA é um programa que foi criado por ocasião do Fome Zero. Por ocasião do PBSM ele foi ampliado.
} 
(Estado, trabalhadores rurais e empregadores) nas cadeias produtivas que empregam mais mão de obra no meio rural, assegurando a melhoria das condições de trabalho, o estímulo à formalização, o incremento da qualificação profissional e dos níveis de escolaridade, bem como o fortalecimento da fiscalização das condições de trabalho;

- Apoio à formação e divulgação de redes de Economia Solidária, de de atividades empreendedoras coletivas, micro e pequenas empresas e constituição de incubadoras para geração de ocupação e renda. Esta iniciativa vale tanto para a inclusão produtiva rural como para a urbana.

Nas cidades, o Plano Brasil sem Miséria pretende gerar ocupação e renda para os mais pobres entre 18 e 65 anos de idade mediante cursos de qualificação profissional, intermediação de emprego, ampliação da política de microcrédito e incentivo à economia popular e solidária.

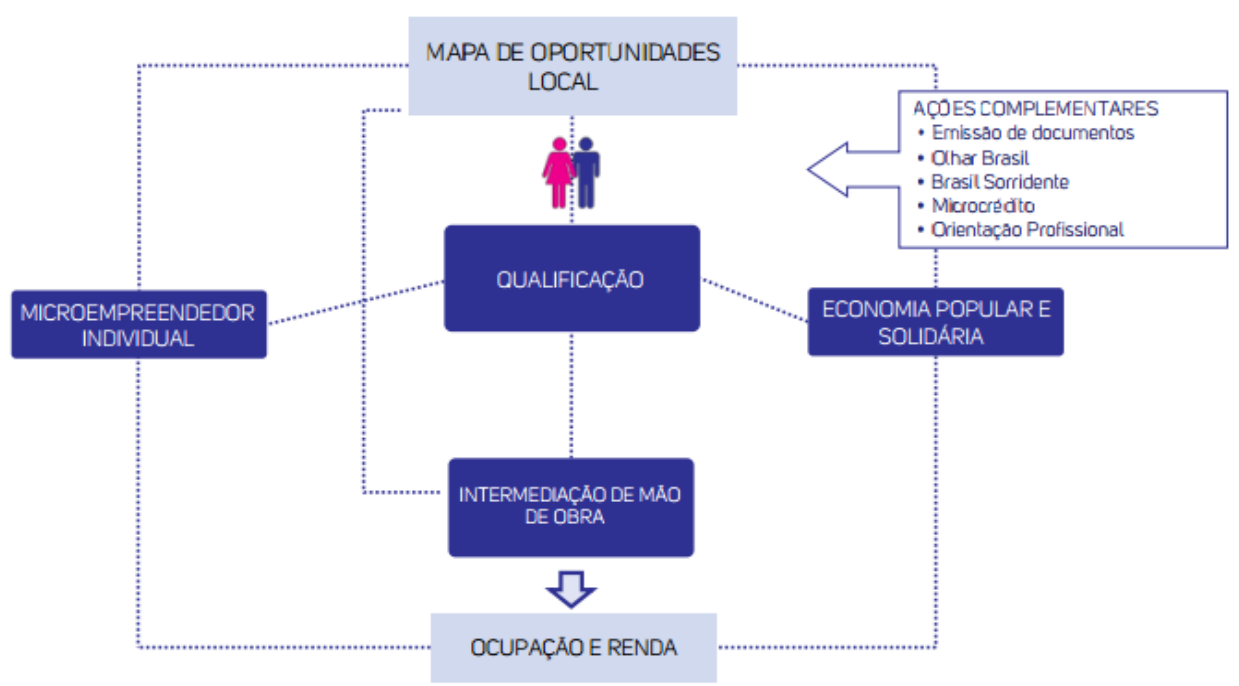

Figura 4- Inclusão Produtiva Urbana.

Fonte: Mds, 2011, Caderno do Plano Brasil Sem Miséria.

As ações voltadas para a inclusão produtiva urbana, da mesma maneira da rural, centraram-se na ampliação das já existentes, bem como na criação de novas ações. Quanto a ampliação e adequação das já existentes, podemos destacar:

- Geração de ocupação e renda para os mais pobres, entre 18 e 65 anos de idade, mediante cursos de qualificação profissional e intermediação de emprego. Projeta-se a oferta de mais de duzentos tipos de cursos, por meio das escolas 
técnicas públicas e privadas. Os cursos serão certificados e gratuitos, e os alunos receberão material pedagógico, lanche e transporte. Os cursos deverão estar de acordo com a vocação econômica de cada região. Colocação de trabalhadores por meio de vagas captadas junto às empresas. No tocante à intermediação de emprego, esse trabalho será realizado a partir do Mapa de Oportunidades em cada município;

- A ampliação da política de microcrédito, através do Programa Nacional de Microcrédito Produtivo Orientado (Crescer), que pretende facilitar o acesso ao crédito orientado, para que parte do público do Brasil sem Miséria possa ampliar pequenos negócios, com incentivo à formalização e geração de trabalho e renda. O valor máximo do empréstimo, de até $\mathrm{R} \$ 15$ mil, deve estar vinculado a atividades produtivas. Os juros foram reduzidos de $60 \%$ para $8 \%$ ao ano. A Taxa de Abertura de Crédito (TAC) sofreu redução de $3 \%$ para $1 \%$ sobre o valor do financiamento. A princípio serão os bancos públicos os responsáveis pela implementação do programa;

- Fortalecimento do microempreendedor individual, prosseguindo no esforço de promoção da formalização de pequenos negócios de trabalhadores que atuam por conta própria, junto as áreas tributária e previdenciária;

- Incluir os extremamente pobres como trabalhadores nas grandes obras de infraestrutura do Plano Nacional de Aceleração do Crescimento ${ }^{64}$ (PAC) e daquelas relacionadas com a Copa do Mundo de 2014 e as Olimpíadas de 2016, oferecendo a estes cursos de capacitação profissional (estimativa de 1,7 milhão de pessoas).

\section{Gestão e Financiamento do PBSM}

O Decreto $n^{\circ} 7.492 / 2011$, que institui o Plano Brasil Sem Miséria, previu uma gestão intersetorial e interministerial para o mesmo e estabeleceu as seguintes instâncias para sua gestão:

- Comitê Gestor Nacional, instância de caráter deliberativo, que tem como atribuições fixar metas e orientar a formulação, a implementação, o

\footnotetext{
${ }^{64}$ Em 2014 foi criado do PAC 2.
} 
monitoramento e a avaliação do Plano. É composto pelos titulares dos ministérios do Desenvolvimento Social e Combate à Fome, que o coordena; da Fazenda; do Planejamento, Orçamento e Gestão e pela Casa Civil da Presidência da República. A Secretaria-Executiva do Comitê Gestor Nacional está a cargo da Secretaria Extraordinária para a Superação da Extrema Pobreza do MDS.

- Grupo Executivo, que tem como atribuição assegurar a execução de políticas, programas e ações desenvolvidos no âmbito do Plano e que é composto pelos Secretários-Executivos dos órgãos que fazem parte do Comitê Gestor Nacional.

* Grupo Interministerial de Acompanhamento do Plano Brasil Sem Miséria, que tem como atribuição o monitoramento e a avaliação de políticas, programas e ações desenvolvidos no âmbito do Plano. É composto pelos seguintes órgãos: Ministério do Desenvolvimento Social e Combate à Fome, que o coordenará; Casa Civil da Presidência da República; Secretaria-Geral da Presidência da República; Ministério da Fazenda; Ministério do Planejamento; Orçamento e Gestão; Ministério das Cidades; Ministério do Trabalho e Emprego; Ministério do Desenvolvimento Agrário; Ministério da Saúde; Ministério da Educação e Ministério da Integração Nacional.

Com relação ao financiamento, segundo o decreto que instituiu o Plano, preveem-se as seguintes fontes de recursos para seu financiamento:

- Dotações orçamentárias da União consignadas anualmente nos orçamentos dos órgãos e entidades envolvidos no Plano Brasil Sem Miséria;

- Recursos provenientes dos órgãos participantes do Plano Brasil Sem Miséria, fora dos Orçamentos Fiscal e da Seguridade Social;

- Outras fontes de recursos destinadas por Estados, Distrito Federal e Municípios, bem como por outras entidades públicas e privadas.

Com relação ao financiamento do Plano Brasil Sem Miséria, até o ano de 2014 já haviam sido desembolsados mais de 80 bilhões de reais. 
Plano Rio Sem Miséria: estratégia de redução à pobreza no estado do Rio de Janeiro

\section{1.}

O cenário econômico e social do estado do Rio de Janeiro

Vários indicadores podem ser utilizados para dimensionar os tipos e a magnitude da desigualdade social no Rio de Janeiro, sendo que neste momento não se trata de realizar um inventário detalhado das condições de vida da população, mas de fornecer um quadro sintético de algumas dimensões que traduzem aspectos de vulnerabilidade e de exclusão social.

Com uma área de 43.780,172, km2, o Estado do Rio de Janeiro representa 0,51\% do território brasileiro. Seu território está dividido em 92 municípios, distribuídos em oito regiões de governo: Metropolitana, Noroeste Fluminense, Norte Fluminense, Serrana, das Baixadas Litorâneas, do Médio Paraíba, Centro Sul-Fluminense, da Costa Verde (CEPERJ, 2013).

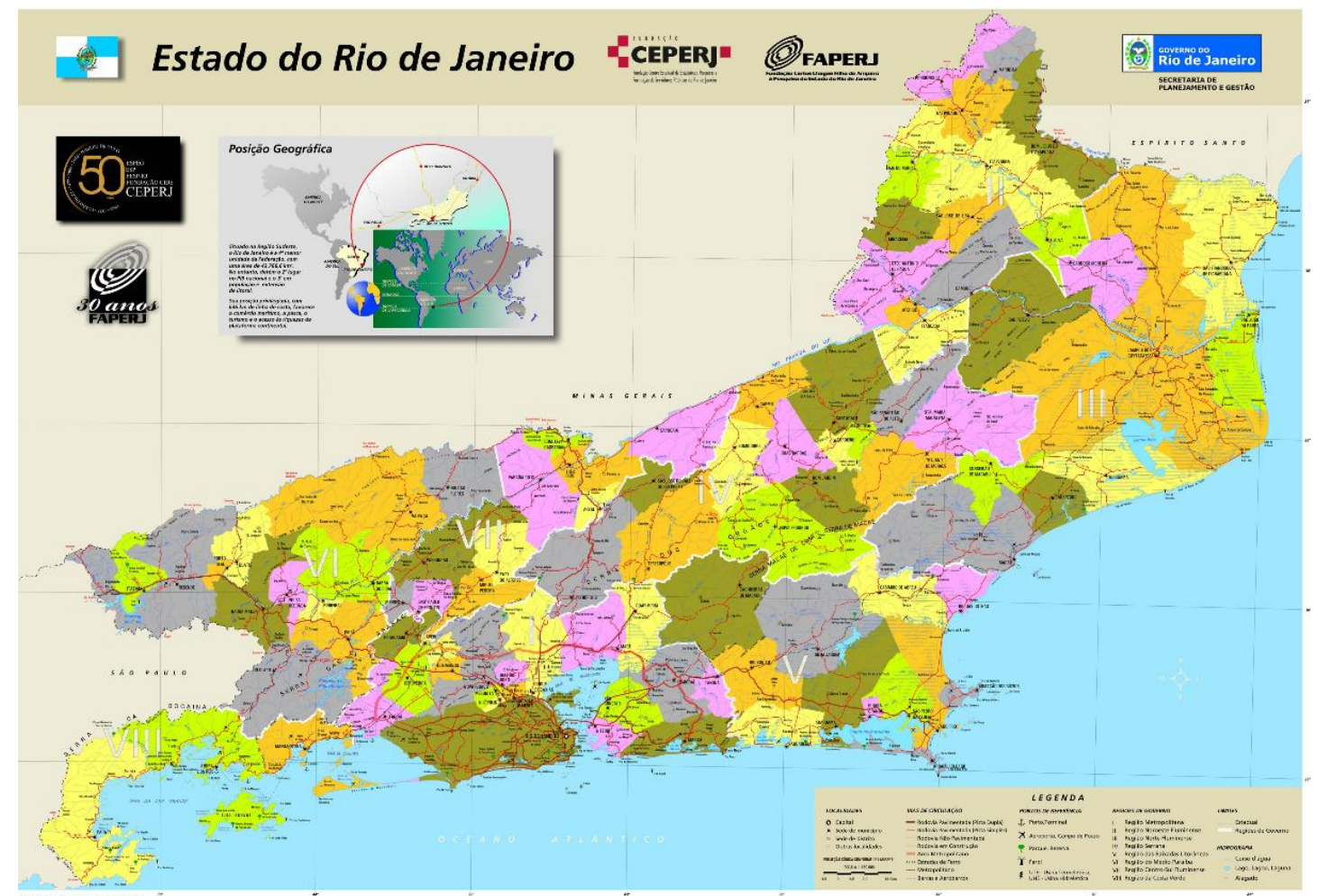

Figura 5- Mapa político do estado do Rio de Janeiro. Fonte: CEPERJ, 2015. 
Em 2013, a população do Estado a chegou a 16.369.178 habitantes, sendo que a maior parte desse contingente populacional concentra-se na Região Metropolitana $(73,7 \%)$ e em áreas urbanas, visto que, em 2010, 96,7\% da população residia nessas áreas. Dentre as regiões do Estado, a Região Metropolitana foi a que apresentou a maior taxa de urbanização $(99,5 \%)$. E a Região Noroeste Fluminense foi a que apresentou a menor taxa $(82,6 \%)$ (CEPERJ, 2013).

De acordo com Antonio Claret, formulador e gestor do PRSM a situação da população fluminense e sua distribuição no espaço geográfico merece atenção especial:

No estado do Rio de Janeiro, podemos observar a alta concentração de população na região metropolitana e na baixada fluminense, o que requer atenção especial por parte dos gestores ocasião da formulação das políticas públicas, objetivando atender as demandas dessa população, que apresenta condições de vida especificas em relação as demais. Um grande exemplo é o caso das pessoas que precisam efetuar grandes deslocamentos para trabalhar, visto que não há oportunidades de trabalhos na sua cidade, mas somente nas cidades próximas, fazendo com que sua cidade se torne apenas um dormitório. (Antônio Claret, Formulador e Gestor do PRSM)

Como informação relevante, além dos dados sobre a população é importante destacar que o Rio de Janeiro é a segunda unidade da federação em termos de PIB (R \$ 462. 376 milhões), sendo que este indicador apresentou em 2011 o crescimento real de $2,1 \%$ inferior ao de 2010 que foi de 4,5\%. (CEPERJ,2013).

Além dos dados acima, o Estado do Rio é o primeiro colocado no cenário nacional no que se refere a geração de empregos no ano de 2012, nos meses de novembro e dezembro Segundo os dados do Cadastro Geral de Empregados e Desempregados (Caged), divulgados pelo Ministério do Trabalho e foram gerados 14.051 empregos com carteira assinada, em novembro. É a maior marca do mês entre todos os estados brasileiros, com expansão de $0,36 \%$ em relação ao mês anterior. Essa geração de empregos vem sido uma constante no anos de 2011 e 2012, quando o Estado tem demonstrado uma grande capacidade de geração de empregos. 
Observa-se que a economia do Estado fluminense apresenta-se em constante ascensão com geração de emprego e renda. Mas mesmo diante deste cenário, podemos afirmar que o Estado tem na desigualdade de renda uma das suas matrizes mais marcantes e que se configura como um dos principais desafios norteadores para a implantação das políticas públicas de acordo com as entrevistas realizadas com os formuladores e gestores do Plano Rio Sem Miséria, especialmente no que se refere a área da Assistência Social e, conforme veremos pelos dados apresentados a seguir.

De acordo com os estudos realizados pelo IPEA e FGV observa-se que última década, enquanto nos outros estados da região sudeste, o índice de Gini ${ }^{65}$ segue em uma tendência de queda, no Rio de Janeiro o índice permanece estagnado, demonstrando que o crescimento econômico não implica na justa distribuição de renda e na redução das desigualdades, conforme podemos observar a seguir.

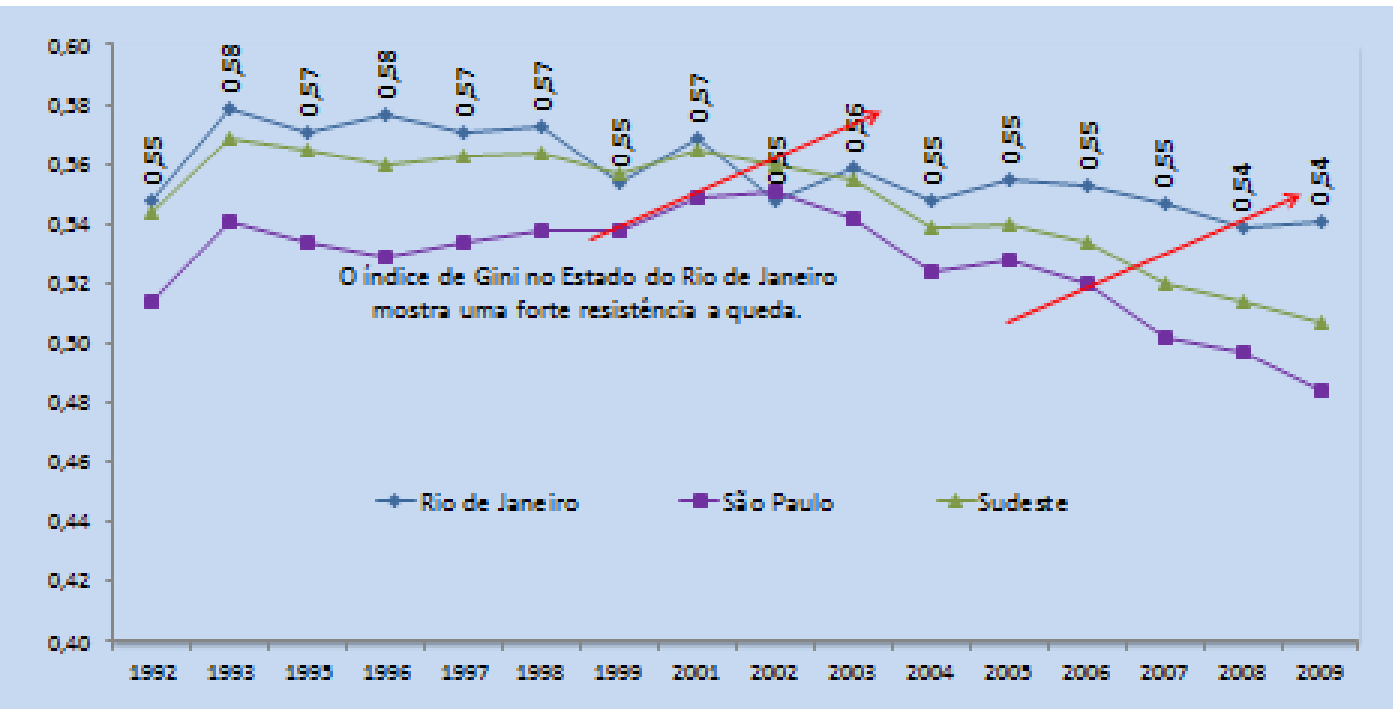

Gráfico 3- comparativo da evolução do índice de Gini entre o Rio de Janeiro, São Paulo e a região Sudeste.

Fonte: Seasdh, 2013

${ }^{65}$ O Coeficiente de Gini é utilizada para calcular a desigualdade de distribuição de renda qualquer distribuição. Ele consiste em um número entre 0 e 1 , onde 0 corresponde à completa igualdade de renda ou rendimento (onde todos têm a mesma renda) e 1 corresponde à completa desigualdade (onde uma pessoa tem toda a renda ou rendimento, e as demais nada têm). O índice de Gini é o coeficiente expresso em pontos percentuais (é igual ao coeficiente multiplicado por 100). 
Conforme estudos realizados por Paes de Barros (2011), em 1992 a renda per capita domiciliar médias das familiar cariocas era de $\mathrm{R} \$ 569,00$, ficando o estado em $2^{\circ}$ lugar no país, atrás somente do Distrito Federal. No ano de 2009, em nova pesquisa, a renda per capita média das famílias cariocas passou para $R \$$ 835,00 , registrando a queda de apenas uma posição e ficando com a terceira maior renda entre os estados brasileiros.

\begin{tabular}{|c|c|c|c|c|c|c|c|}
\hline \multirow{2}{*}{ Posição } & \multirow{2}{*}{ Estados } & \multicolumn{2}{|c|}{$\begin{array}{l}\text { Renda Domiciliar } \\
\text { Per Capita }\end{array}$} & \multirow[t]{2}{*}{ Posição } & \multirow[t]{2}{*}{ Estados } & \multicolumn{2}{|c|}{$\begin{array}{l}\text { Renda Domicilia } \\
\text { Per Capita }\end{array}$} \\
\hline & & 1992 & & & & 2005 & \\
\hline 1 & Distrito Federal & RS & 664,00 & 1 & Distrito Federal & RS & $1.324,00$ \\
\hline 2 & Rio de Janeiro & RS & 569,00 & 2 & Santa Catarina & RS & 865,00 \\
\hline 3 & São Paulo & $R \$$ & 569,00 & 3 & Rio de Janeiro & $R S$ & 835,00 \\
\hline 4 & $\begin{array}{l}\text { Rio Grande do } \\
\text { Sul }\end{array}$ & RS & 524,00 & 4 & São Paulo & RS & 807,00 \\
\hline 5 & Santa Catarina & RS & 496,00 & 5 & $\begin{array}{l}\text { Rio Grande do } \\
\text { Sul }\end{array}$ & RS & 774,00 \\
\hline
\end{tabular}

Gráfico 4- Evolução da renda per capita domiciliar dos estados brasileiros - 1992/2009. Fonte: SEASDH, 2011.

Porém, se realizarmos uma análise da desigualdade de renda, iremos observar que no mesmo período, houve uma queda da décima para a décima sétima posição. Ou seja, mesmo ampliando o PIB, isto não resultou na ampliação da renda das famílias do Estado do Rio de Janeiro, especialmente aquelas que vivem em situação de extrema pobreza.

\begin{tabular}{|c|c|c|c|c|c|}
\hline \multirow{2}{*}{ Posição } & \multirow{2}{*}{ Estedos } & \multirow{2}{*}{$\frac{\text { Indice de Gini }}{1992}$} & \multirow{2}{*}{ Posiçĩo } & \multirow{2}{*}{ Estedos } & \multirow{2}{*}{$\begin{array}{c}\text { Indice de Gini } \\
2009\end{array}$} \\
\hline & & & & & \\
\hline 9 & Rondônia & 0,545 & 9 & Minas Gerais & 0,509 \\
\hline 10 & Rio de Janeiro & 0,548 & 10 & Pará & 0,516 \\
\hline 11 & Pará & 0,549 & 11 & Mato Grosso do Sul & 0,517 \\
\hline 12 & Amazonas & 0,551 & 12 & Amapá & 0,519 \\
\hline 13 & Espirito Santo & 0,555 & 13 & Roraima & 0,521 \\
\hline 14 & Acre & 0,559 & 14 & Tocantins & 0,522 \\
\hline 15 & Minas Gera's & 0,566 & 15 & Espirito Santo & 0,528 \\
\hline 16 & Alagoes & 0,575 & 16 & Maranhão & 0,537 \\
\hline 17 & Mato Grosso do Sul & 0,581 & 17 & Rio de Janeiro & 0,541 \\
\hline 18 & Goís & 0,581 & 18 & Ceará & 0,542 \\
\hline
\end{tabular}

Gráfico 5- Índice de Gini no Estado do Rio de Janeiro - Comparativo 1992 e 2009. Fonte: Seasdh, 2011. 
Os estudos demonstram ainda que mesmo com a terceira maior renda per capita média entre os estados brasileiros e o segundo maior PIB dos pais, de acordo com o censo IBGE/2010, mais de 586 mil pessoas ainda vivem com renda per capita inferior a $\mathrm{R} \$ 77,00^{66}$, colocando o Estado em $17^{\circ}$ no ranking das desigualdades entre os estados brasileiros.

As pesquisas e análises realizadas nos permitem ainda auferir a situação de desigualdade refere-se apenas aos aspectos monetários, não levando em consideração aspectos como o acesso a serviço públicos ou a pobreza no sentido de outras necessidades e da liberdade de escolhas, no sentido das capacidades conforme preceituado por Sen e discutido no segundo capítulo da presente pesquisa.

Após a análise do contexto do estado do Rio de Janeiro no que se refere ao cenário econômico e de geração de empregos, observamos um processo de avanços. Porém, os mesmos avanços não podem ser percebidos no que se refere a distribuição das riquezas produzidas entre as classes, por isso a necessidade de intervenção por meio de políticas públicas, como é o caso do Plano Rio Sem Miséria, conforme veremos a seguir.

\section{2. \\ Concepções fundantes do Plano Rio Sem Miséria}

Diante deste cenário de produção e reprodução da desigualdade no Estado e mediante a iniciativa do Governo Federal ao implantar o PBSM, que conclamou os governos subnacionais e municipais, bem como a sociedade civil em torno do objetivo civilizatório fundamental de erradicar a extrema pobreza no Brasil, o Governo do Estado do Rio de Janeiro tomou a decisão de incluir em sua agenda prioritária a elaboração de um plano estadual de redução à pobreza, o Plano Rio Sem Miséria.

Por ocasião do lançamento do Plano Brasil Sem Miséria em Brasília, em agosto de 2011, o governador do Rio de Janeiro foi convidado pela Presidente Dilma a

\footnotetext{
${ }^{66}$ A época da criação do Plano, o corte de renda era de $\mathrm{R} \$ 70,00$ para a extrema pobreza.
} 
apresentar a estratégia para a superação da pobreza do Estado, o Plano Rio Sem Miséria, ou seja, a nossa estratégia foi concebida no mesmo momento em que foi concebida a estratégia federal. Então o Rio de Janeiro estava a frente dos outros estados brasileiros no seu Plano. Inclusive foi destaque nacional o governador Cabral sendo fotografado ao lado da presidente Dilma com o cartão do Programa Renda Melhor, que complementa o beneficio do Programa Bolsa Família. Servimos de referência e incentivo para as outras Unidades de Federação criarem os seus Planos, alinhados ao plano federal, o Brasil Sem Miséria. (Antônio Claret, formulador e gestor do PRSM)

A execução do PBSM com a atuação integrada de governos subnacionais e municipais sobre a plataforma federal do Cadastro Único, complementando ações e, ao mesmo tempo inovando em ações, de acordo com o contexto econômico e social local, como é o caso do estado do Rio de Janeiro, demonstra que política brasileira está entrando no que pode ser chamado de novo federalismo social ${ }^{67}$.

Uma das grandes inovações do Plano do Estado do Rio de Janeiro é ter sua atuação sobre a plataforma do governo federal: do Cadastro Único e do Programa Bolsa Família ou sob o novo federalismo social. Essa atuação é um avanço nas políticas públicas visto que permite a utilização de informações acerca das famílias, disponibilizadas pelo Cadastro Único para a identificação do público alvo, bem como as famílias do Programa Bolsa Família. Tal estratégia evita a duplicação de ações bem como garante celeridade às ações do Plano, visto que já sabemos qual será o nosso público alvo. (Antônio Claret, Formulador e Gestor do PRSM)

Portanto, participação da esfera estadual é muito importante no sentido de contribuir para ganhos de escala na implementação de políticas no bojo do PBF e demais programas, que até então refletiam uma ação direta entre o governo federal e o governo municipal.

É importante destacar ainda que a informações produzidas pelas Gestões Municipais por ocasião da manutenção da base do Cadastro Único podem ser utilizadas por outras políticas públicas como é o caso do PRSM. Essas ações são muito importante, pois abrem o leque de opções para os quais o cadastro deve ser utilizado, bem como evitam o trabalho específico da Gestão para o Plano. Ou seja, no momento em que estão sendo efetuadas as ações de atualização ou revisão cadastral por exemplo, as informações das famílias já estão estão sendo atualizadas para o Cadastro, para o Bolsa Família e para o Plano Rio Sem Miséria .A Coordenação Estadual do Programa Bolsa Família e do Cadastro Único presta

${ }^{67}$ De acordo com Neri (2012) no novo federalismo social os entes federados atuam sobre a plataforma do Governo Federal (Bolsa Família e Cadastra Único) complementando ou inovando nas ações. 
o apoio técnico e operacional às Gestões Municipais nestas ações. (Ana Vieira, Superintendente de Renda de Cidadania)

Outro aspecto relevante do Plano é a concepção de pobreza utilizada, que consitui-se como um de suas estruturas basilares de atuação: a partir da compreensão da necessidade de um conjunto de ações articuladas para enfrentar os múltiplos determinantes da pobreza, visto que o Plano parte da premissa de que a pobreza extrema não se refere apenas a insuficiência de renda, mas da desigualdade, composta por um conjunto de fatores dentre os quais podemos citar o desigual acesso às políticas públicas e as oportunidades sociais e econômicas, presentes nas diversas dimensões da vida das famílias e das pessoas ( Guia Para a Gestão Municipal do Programa Renda Melhor, 2014, p.p.16, 17).

As concepções de pobreza do Plano parte de um pressuposto muldimensional, ou seja, não levadas em consideração apenas os aspectos monetários para definição do público alvo, mas de um conjunto de fatores que contempla outros aspectos das vida das famílias como o acesso a oportunidades, que proporciona as famílias a possiblidade de liberdade para fazer escolhas assumindo o protagonismo das suas vidas. (Antonio Claret, Formulador e Gestor do PRSM)

Para os formuladores do Plano, as dimensões de funcionamento da vida afetadas pela pobreza são as seguintes: alimentação, dinâmica familiar, inserção da comunidade, educação, perspectiva de futuro, moradia, cultura, vestuário, satisfação pessoal, auto estima, trabalho e renda, saúde e lazer.

A pobreza, para as concepções fundantes do Plano perpassa aspectos que podemos medir: ela está em aspectos não tangíveis, que não podem ser mensurados, pois atingem de maneira muito pessoal e individual cada pessoa e cada família. São aspectos relacionados a auto estima, satisfação pessoal, perspectiva de futuro por exemplo. A ausência destes acaba interferindo de maneira incisiva na vida das pessoas e gera assim o agravamento das condições da pobreza. Por isso, o PRSM tem como objetivo também estes aspectos, por meio de suas estratégias, proporcionando assim que as famílias possam ter condições de fazer escolhas, bem como liberdade para efetuá-las. Nesse aspecto, alguns fundamentos do Plano vão ao encontro dos fundamentos teóricos de Amartya Sen. (Antonio Claret, Formulador e Gestor do PRSM)

Ou seja, as oportunidades para as pessoas e famílias propostas no Plano vão além de aspectos de transferência de renda ou de oportunidades econômicos, 
mas compõem um arcabouço misto de oportunidades econômicas e sociais, além de aspectos menos tangíveis como auto estima, liberdade e possibilidade e oportunidade de escolhas.

O Plano não tem como objetivo apenas a mera transferência de renda para as famílias, mas sim um conjunto de oportunidades que visam ampliar o acesso as políticas públicas, com foco no desenvolvimento do capital humano. (Luis Gustavo, Superintende de Gestão de Oportunidades)

Diante do exposto e de acordo com Lei Estadual 6.088/11 o PRSM possui como objetivos específicos: i) aumentar a renda das famílias extremamente pobres para o nível além da pobreza extrema, proporcionando condições para buscar realizar suas trajetórias de vida com maior autonomia e dignidade; ii) incentivar a permanência e a conclusão com qualidade do ensino médio dos jovens de famílias em situação de extrema pobreza, contribuindo para ampliar suas oportunidades de inclusão social e econômica e; iii) ampliar a inclusão social da população de baixa renda, articulando as suas capacidades e potencialidades às oportunidades econômicas e sociais.

A fim de atingir os objetivos a que se propõem o Plano, foram estabelecidas estratégias a curto, médio e longo prazo com os objetivos estabelecidos, conforme podemos observar na figura abaixo.

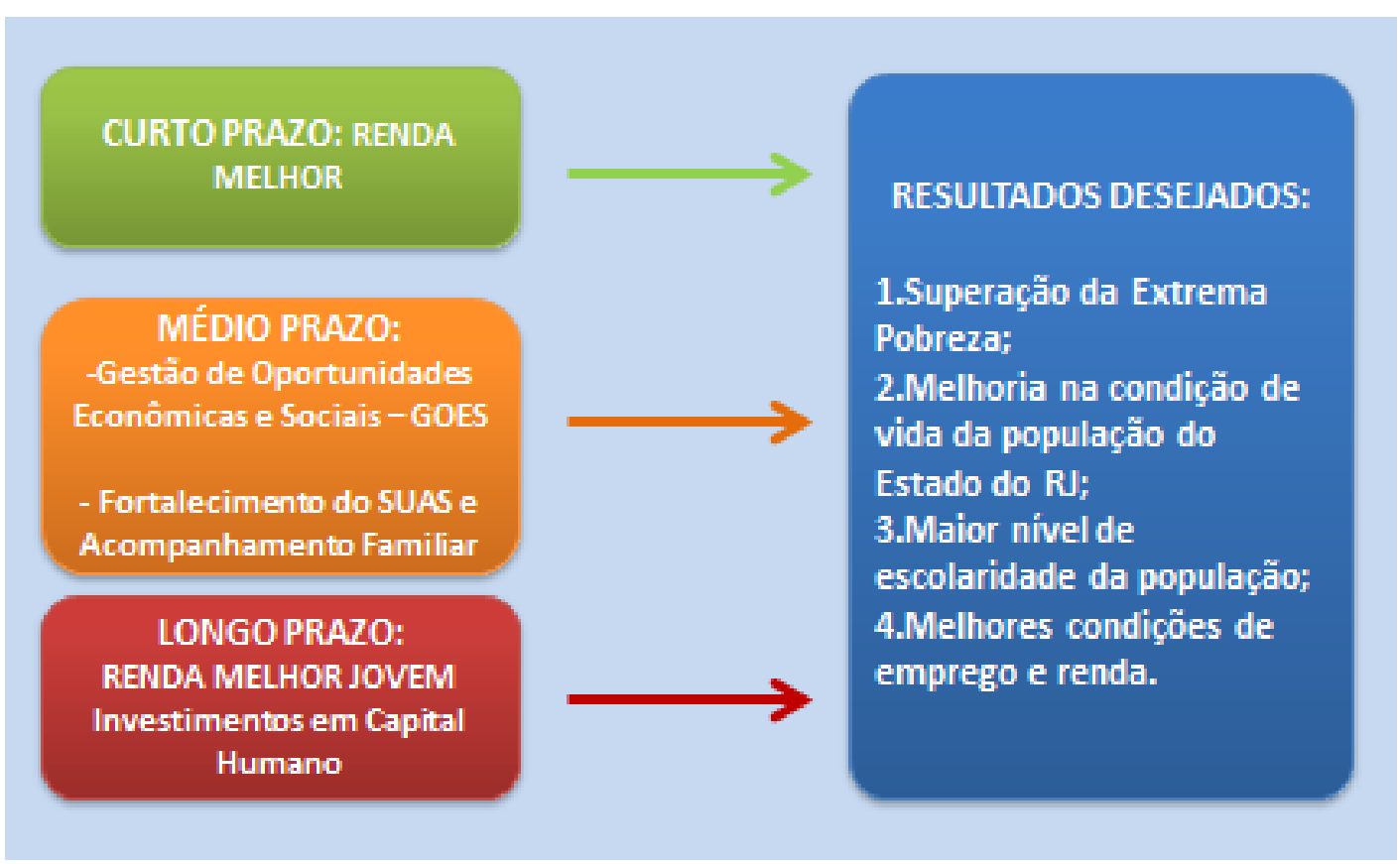

Figura 6- Componentes do PRSM, prazo e os objetivos esperados. Fonte: SEASDH, 2011. 
Dado o caráter multidimensional da concepção de pobreza é necessária uma intervenção multisetorial para a execução do Plano no Estado do Rio de Janeiro, ou seja, optou-se por uma Secretaria, que por meio de uma Subsecretaria exerce o protagonismo da Coordenação do Plano, porém é necessário o envolvimento das demais Secretarias e órgãos do Governo Estadual, assim como da sociedade civil e da iniciativa privada, além do Governo Federal.

\begin{abstract}
Planos dessa ordem, que visam a superação da pobreza requerem um envolvimento multisetorial. São todos os órgãos e Secretarias do Governo do Estado que devem estar envolvidos, assim como a busca de parceria com a sociedade civil por meio dos conselhos e entidades e da iniciativa privada, como parceiros como por exemplo as Federações do Comércio, Agricultura, Indústria que é muito importante no Estado, o Sistema $\mathrm{S}$ e demais entidades e segmentos representativos que possam contribuir para a execução do Plano. (Antonio Claret, formularor e gestor do PRSM)
\end{abstract}

A responsabilidade pela execução do Plano no Estado está a cargo da Secretaria de Estado de Assistência Social e Direitos Humanos (SEASDH), por meio da Subsecretaria de Integração de Programas, composta pelas Superintendência de Renda de Cidadania, que coordena o Programa Renda Melhor e Coordenação Estadual do Programa Bolsa Família e Cadastro Único. Além disso, conta coma Superintendência de Gestão de Oportunidades, responsável pelo Programa Renda Melhor Jovem e Gestão de Oportunidades Econômicas e Sociais.

Com relação a estratégia de Fortalecimento do Suas e Acompanhamento Familiar, a responsabilidade é compartilhada com a Subsecretaria de Assistência Social e Descentralização da Gestão, que faz parte da estrutura da SEASDH. O Programa Renda Melhor Jovem possui gestão compartilhada com a Secretaria Estadual de Educação-SEEDUC.

Assim como o Plano federal, terá o apoio na sua execução de outras Secretarias e órgãos estaduais, federais, municipais, bem como da sociedade civil e do setor privado. Com relação ao financiamento para as ações do Plano, o mesmo está sob a responsabilidade exclusiva do Estado. (Antonio Claret, formulador e gestor do PRSM) 
As gestões municipais exercem um protagonismo muito importante na execução do Plano, visto que é nos municípios que residem as populações alvo do PRSM. Nos municípios fluminenses, a gestão do PRSM está sob a responsabilidade das Secretarias Municipais de Assistência Social. É nos municípios também que as famílias buscam atendimento para as ações do Programa Bolsa Família, do Cadastro Único e do Plano Rio Sem Miséria. Logo, a importância do papel das Gestões Municipais na execução do Plano e das demais politicas a ele relacionadas, explicitando-se em capacidade técnica e operacional para $\mathrm{o}$ atendimento às famílias.

Sabemos da importância do papel das Gestões Municipais para a execução do Plano. Por isso a Subsecretaria de Integração de Programas Sociais por meio das suas Superintendências e Coordenações exerce um trabalho de acompanhamento as Gestões Municipais, oferecendo suporte técnico e operacional, bem como realizando capacitações constantes e continuas. Nos municípios residem os destinatários das ações do Plano: as famílias beneficiárias e elas são muito importantes, visto que estão na situação de extrema pobreza e de pobreza e, por isso necessitam ter suas demandas atendidas sempre que buscarem atendimento. A Coordenação Estadual tem a preocupação de proporcionais condições por meio do apoio técnico e operacional para que os municípios possam atender as demandas no primeiro atendimento, evitando deslocamentos desnecessários para as famílias. (Ana Vieira, Superintende de Renda de Cidadania)

Portanto, podemos observar que o papel protagonista das Gestões Municipais é muito importante para a execução e bom andamento do Plano, visto que o mesmo está alinhado com as estratégias do Governo Federal, que são o Programa Bolsa Família o Cadastro Único e nos municípios a responsabilidade pelo atendimento das famílias as ações destes é das Gestões Municipais. O Estado por sua vez tem o papel de oferecer o suporte necessário para que os municípios tenham a expertise técnica para o atendimento ás demandas das famílias.

Para aprofundar o debate sobre o PRSM, faremos uma descrição detalhada das estratégias do Plano Rio Sem Miséria, visto que a mesma constitui-se em mais uma dimensão da pesquisa, para aprofundar o conhecimento sobre o Plano e sua execução no estado do Rio de Janeiro cujas estratégias são o Programa Renda Melhor, o Programa Renda Melhor Jovem, a Gestão de Oportunidades Econômicas e Sociais e o Acompanhamento Familiar e o Fortalecimento do SUAS. 


\section{3. \\ Programa Renda Melhor (PRM)}

O Programa Renda Melhor é uma das estratégias do Plano Rio Sem Miséria. É um programa de transferência de renda destinado às famílias que já são beneficiárias do PBF e que possuem renda per capita mensal estimada inferior a $\mathrm{R} \$ 100,00$. Foi instituído pelo Decreto $\mathrm{n}^{\circ} 42.949$ de 10 de maio de 2011 e alterado pelo Decreto n ${ }^{\circ} 42.963$ de 11 de maio de 2011.

Isso significa que para ser beneficiário do Programa Renda Melhor a família deve atender a algumas condições: estar incluída no Cadastro Único, já ser beneficiária do Programa Bolsa Família e possuir renda mensal per capita estimada da família inferior a $\mathrm{R} \$ 100,00$. (Ana Vieira, Superintendente de Renda de Cidadania)

Estes requisitos geram uma interdependência entre o Cadastro Único, o Bolsa Família e o Renda Melhor, a qual pode ser melhor visualizada na figura abaixo.

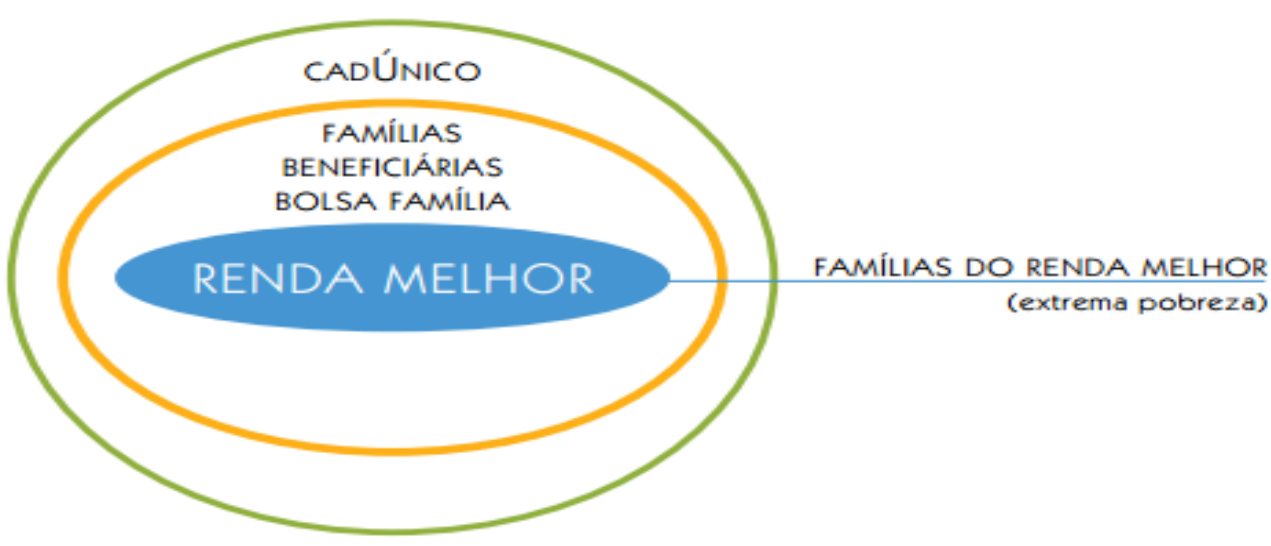

Figura 7- Integração entre Cadastro Único, Programa Bolsa Família e Renda Melhor. Fonte: Guia Para a Gestão Municipal do Programa Renda Melhor, p. 24. Elaboração: Equipe SEASDH.

Outro aspecto importante do Programa é o alinhamento federativo do ao Plano Brasil Sem Miséria: 
O Programa Renda Melhor é uma das estratégias do Plano Rio sem Miséria, criado pela Lei 6.088/11, cujas ações para enfrentamento e superação da pobreza extrema estão alinhadas ao Plano Brasil Sem Miséria do Governo Federal. Logo o Plano Rio Sem Miséria e o Programa Renda Melhor estão num alinhamento federativo com as propostas de políticas públicas do Governo Federal". (Antonio Claret, formulador e gestor do PRSM)

O Programa Renda Melhor tem como objetivos principais:

i) Elevar a renda das famílias beneficiárias do PBF de forma que estas superem a linha de extrema pobreza definida no âmbito do Rio de Janeiro;

ii) Proporcionar ás famílias beneficiárias condições para que realizem suas trajetórias de vida com maior autonomia e dignidade e;

iii) Contribuir para a dinamização das economias locais, em particular das localidades que concentram maiores taxas de extrema pobreza.

Em termos gerais pode-se afirmar, por meio da análise dos objetivos a que o Programa está em consonância com as diretrizes gerais do PRSM, explicitando a abordagem para a redução da pobreza para além do aspecto monetário, abraçando outros aspectos da vida das famílias. Tal afirmação é corroborada pela citação contida no Guia Para a Gestão Municipal do Renda Melhor:

Para além do alívio financeiro imediato com vistas à garantia de uma renda mínima para subsistência diária da família, o Programa Renda Melhor visa dar condições a essas famílias para que tenham acesso às oportunidades econômicas e sociais, por meio do acompanhamento familiar sistemático, realizado pelos Centros de Referência da Assistência Social (CRAS) e Centros Especializados da Assistência Social (CREAS). Isso significa garantir e promover o acesso aos serviços nas áreas de saúde, educação, assistência social e qualificação profissional, além de outros benefícios e serviços essenciais ao desenvolvimento social. (Guia Para a Gestão Municipal do Renda Melhor, 2014, p.25)

Para atingir os fins a que se propõem a estratégia, o Governo do Estado do Rio de Janeiro adotou como linha de pobreza R $\$ 100,00$ mensais per capita, ou seja, superior ao do Governo Federal que é de $\mathrm{R} \$ 77,00^{68}$, dadas as características sócias econômicas próprias do Estado, que é predominantemente metropolitano,

\footnotetext{
${ }^{68}$ Por ocasião da implementação do Plano, as famílias que possuíam renda per capita inferior a R \$ 70,00 eram consideradas em situação de extrema pobreza. Em junho/2014 o valor foi ampliado para $\mathrm{R} \$ 77,00$ pelo Governo Federal, reajustando em $10 \%$.
} 
com altos custos de transporte público, bem como para a aquisição dos produtos da cesta básica ${ }^{69}$.

O número de famílias beneficiárias de acordo com a SEASDH (2015) é de amais de 284 mil famílias e o desembolso mensal para o pagamento dos benefícios é de mais de $\mathrm{R} \$ 24$ milhões.

O valor do benefício a ser pago é calculado de acordo com a severidade de pobreza de cada família, em particular, a partir do conjunto de informações contidas no Cadastro Único, declarada ${ }^{70}$ por esta. É a chamada renda estimada ou renda presumida, uma inovação trazida pelo Programa, que leva em consideração as características estruturais que melhor expressam as condições de extrema pobreza das famílias, originadas pela renda, mas que no seu conjunto são oriundas de fatores que perpassam a renda, ou seja, expressam um conjunto de desigualdades sociais e econômicas, além de permitir uma seleção mais adequada das famílias, ao considerar suas individualidades e particularidades.

De acordo com as informações contidas no Guia Para a Gestão Municipal do Renda Melhor:

O cruzamento dessas informações é feito a partir de um modelo de estimação de renda desenhado pelo Centro de Políticas Sociais da Fundação Getúlio Vargas (CPS/FGV). Esse modelo estatístico utiliza essas informações contidas no Cadastro Único para compor uma equação, a qual gera como resultado um valor que estima/presume a renda da família - daí o conceito de renda estimada/presumida. (Guia Para a Gestão Municipal do Renda Melhor, 2014, p.28)

Para o cálculo da renda estimada são considerados:

a) configuração física da moradia;

b) acesso aos diversos serviços públicos como água, esgoto e luz;

c) nível de escolaridade das pessoas do domicílio;

d) inserção no mercado de trabalho;

\footnotetext{
${ }^{69}$ De acordo com pesquisas do DIEESE, do ano de 2010.

${ }^{70}$ As informações contidas no Cadastro Único são auto declaratórias, sem a necessidade de comprovação
} 
e) presença de grupos vulneráveis (pessoas com deficiência, idosos, crianças) e;

f) acesso a transferências federais de renda.

O conceito de renda estimada/presumida tem como objetivo a captura de informações das famílias para além do aspecto monetário, contemplando outros aspectos, para sejam possível identificar as famílias em situação de extrema pobreza.

A metodologia de renda estimada/presumida foi desenvolvida em conjunto com a FGV (Centro de Políticas Sociais), com o objetivo de captar as determinantes estruturais que caracterizam uma família em situação de extrema pobreza, considerando não apenas o aspecto renda monetária. Uma das grandes preocupações é capturar a situação real da família, vivenciada naquele momento para que possamos contemplar as famílias que estão em situação de extrema pobreza, que é o foco prioritário do Plano. (Ana Vieira, Superintendente de Renda de Cidadania)

$\mathrm{Na}$ figura abaixo, podemos observar o processo de estimação de renda do Programa Renda Melhor, para a identificação das famílias que deverão receber o benefício, bem como para apurar o valor a ser pago a cada família. De acordo com o Guia para a Gestão Municipal do Programa Renda Melhor (2014, p.28):

É importante destacar que a esta renda estimada é somado o valor do benefício do PBF recebido pelas famílias e, após este somatório, chega-se à renda presumida per capita mensal das famílias. As famílias cuja renda presumida per capita mensal tenha sido inferior a $\mathrm{R} \$ 100,00$ (cem reais) têm direito a receber os benefícios do Programa Renda Melhor. 


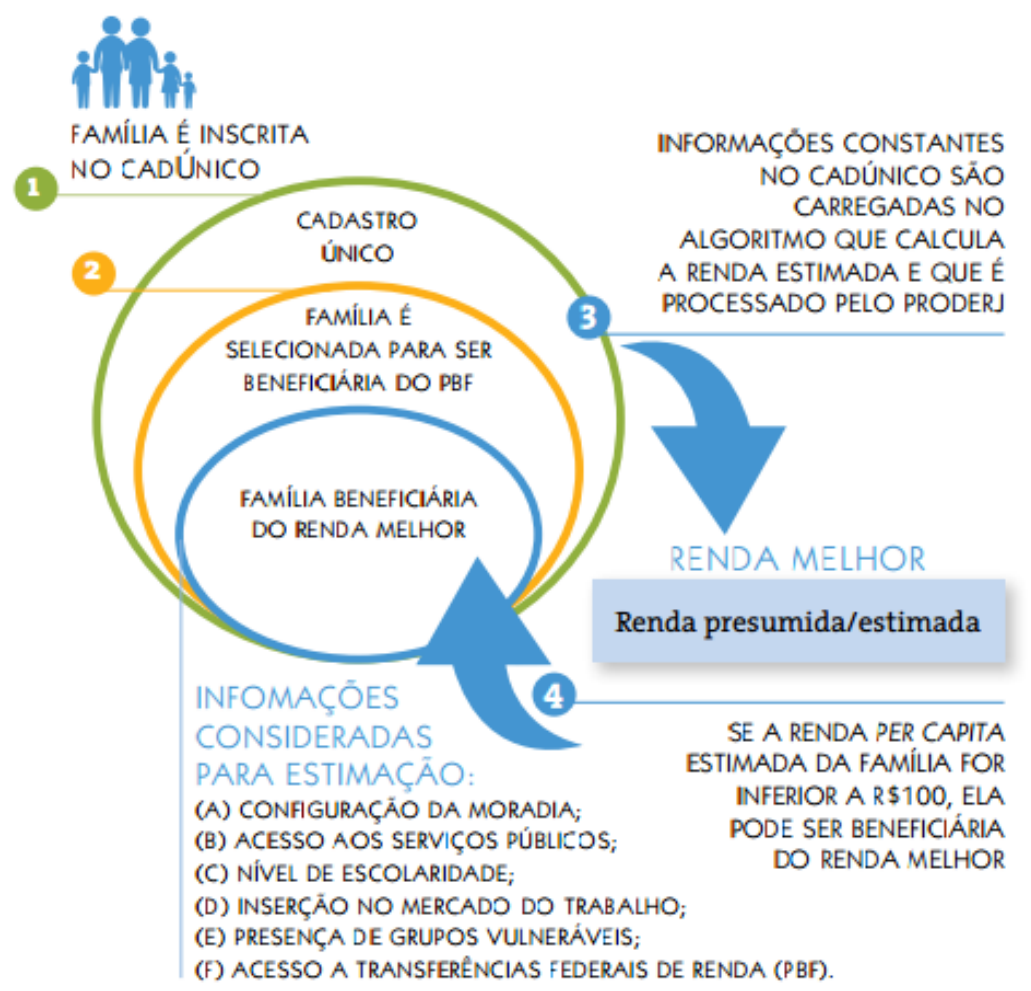

Figura 8- Estimação de renda do Programa Renda Melhor

Fonte: Guia para a Gestão Municipal do Programa Renda Melhor (2014, p.30)

A renda estimada/presumida é também uma maneira de avaliar o grau de vulnerabilidade individual das famílias, capturando as dimensões de pobreza que específica das mesmas. Além disso, de acordo com a dimensão, permitem intervenções de outras políticas públicas para além da renda.

A Renda Estimada/Presumida, portanto é uma forma de avaliar o nível de vulnerabilidade econômico e social da família. Ainda que duas famílias possuam o mesmo rendimento financeiro declarado no Cadastro Único, a família que estiver com piores condições de vida e maior carência de acesso a serviços públicos poderá ser contemplada com um maior valor de benefício do Programa Renda Melhor, não levando em consideração apenas aspectos monetários mas a sua condição histórica, ou seja, o processo de formação da pobreza da família, quando olhamos a sua escolaridade, bem como a sua situação atual, quando olhamos o acesso ao mercado de trabalho e a serviços públicos, por exemplo. Estamos dessa maneira capturando diversas dimensões da pobreza em diversos momentos da vida das famílias. (Antonio Claret Formulador e Gestor do PRSM)

De acordo com as informações contidas no " Guia para a Gestão Municipal do Programa Renda Melhor (2014, p. 30), a Gestão Municipal, bem como as famílias beneficiárias, ou então a equipe técnica do estado não poderão efetuar o cálculo da renda presumida/estimada: 
Os profissionais da Rede SUAS e as famílias não possuem os insumos para realizar essa apuração. $\mathrm{O}$ cálculo da renda presumida é o resultado de uma combinação de diversas informações existentes no Cadastro Único. É utilizado um algoritmo desenvolvido pela FGV e já executado pelo PRODERJ para a geração da folha raiz. Ou seja, é um processo sistêmico e estatístico, o qual utiliza informações socioeconômicas constantes no Cadastro Único relacionadas a diversas dimensões da vida: acesso a serviços públicos, composição familiar, escolaridade, situação no mercado de trabalho dos membros da família, características da moradia e o valor do benefício do Programa Bolsa Família.

O valor repassado ás famílias varia de $\mathrm{R} \$ 30,00$ a $\mathrm{R} \$$ a 300,00 de acordo com a renda estimada/presumida e o pagamento é efetuado por meio de cartão compartilhado, com o Programa Bolsa Família, ou seja, a família utiliza o mesmo cartão para os dois benefícios, conforme veremos mais adiante.

As condicionalidades do PRM são as mesmas do PBF e o acompanhamento das condicionalidades é um reforço ao direito e garantia de acesso das famílias aos serviços básicos de saúde, educação e assistência social. Caso uma situação de descumprimento seja identificada, o sistema de proteção social é acionado para tomar as medidas necessárias para que o acesso aos direitos seja reestabelecido.

A participação da sociedade na formulação, na gestão e no controle social das políticas públicas é a forma como os cidadãos exercem seu direito de controle social. Por isso, o Programa Renda Melhor prevê como responsável pelo controle social do Programa o mesmo controle responsável pela fiscalização e acompanhamento do Programa Bolsa Família na esfera municipal. Já na esfera estadual, Conselho responsável pelo controle social do PRM é o Conselho Estadual de Assistência Social, o CEAS.

O PRM apresenta algumas especificidades com relação a fiscalização, visto que de forma a fortalecer ainda mais o modelo de fiscalização do programa Renda Melhor e em conformidade com o disposto no $\S 3^{\circ}$ do Artigo $8^{\circ}$ da Lei 6088/2011, foi firmado em 29/12/2011 o Termo de Cooperação Técnica $n^{\circ} 05$ com o Ministério Público do Estado do Rio de Janeiro, com vistas a estabelecer entre os signatários, integrantes da Rede Pública de Fiscalização, compromissos e responsabilidades referentes ao resguardo e controle de bens, valores e direitos relativos ao Plano de Superação da Pobreza Extrema, mais especificamente, os Programas Renda Melhor e Renda Melhor Jovem, bem como o monitoramento do 
Sistema Único de Assistência Social (SUAS) no âmbito do Estado do Rio de Janeiro.

Para melhor compreensão do PRSM passaremos a descrever alguns aspectos de maior relevância do Programa, a fim de uma compreensão integral do objeto da pesquisa.

\section{Adesão dos municípios ao Programa Renda Melhor}

O Programa Renda Melhor foi implantado em 2011, concomitantemente com o início do Plano nos municípios de Japeri (a partir de junho), Belford Roxo (a partir de julho) e São Gonçalo (a partir de agosto), como "projeto piloto" do Plano e do Programa.

A opção pela realização de um projeto piloto foi escolhida para que tivéssemos a noção de como seria executar o Plano e o Programa no Estado. A partir da experiência do projeto inicial, com alguns ajustes poderíamos proceder para a ampliação do Programa para os demais municípios do Estado. A escolha dos municípios de Japeri, São Gonçalo e Belford Roxo deveu-se ao fatos dos mesmos possuírem os menores Índices de Desenvolvimento Humano (IDH) do Estado naquele momento. (Ana Vieira, Superintendente de Renda de Cidadania)

Em janeiro/2012, o município de Magé passou a fazer parte do Programa e, em março/2012, outros quarenta e sete (47) municípios foram incluídos no Programa, totalizando 51 municípios. A partir de julho de 2013 foram incluídos mais 40 municípios (Decreto 44.295 de 12/07/13) totalizando 91 municípios, passando a atender todo o Estado do Rio de Janeiro. ${ }^{71}$

Abaixo, segue o mapa com as inclusões dos municípios do Estado no Programa Renda Melhor.

${ }^{71}$ O município do Rio de Janeiro não participa do Programa Renda Melhor, visto que são atendidas por um programa próprio, o Programa Cartão Família Carioca, muito semelhante ao PRM. 


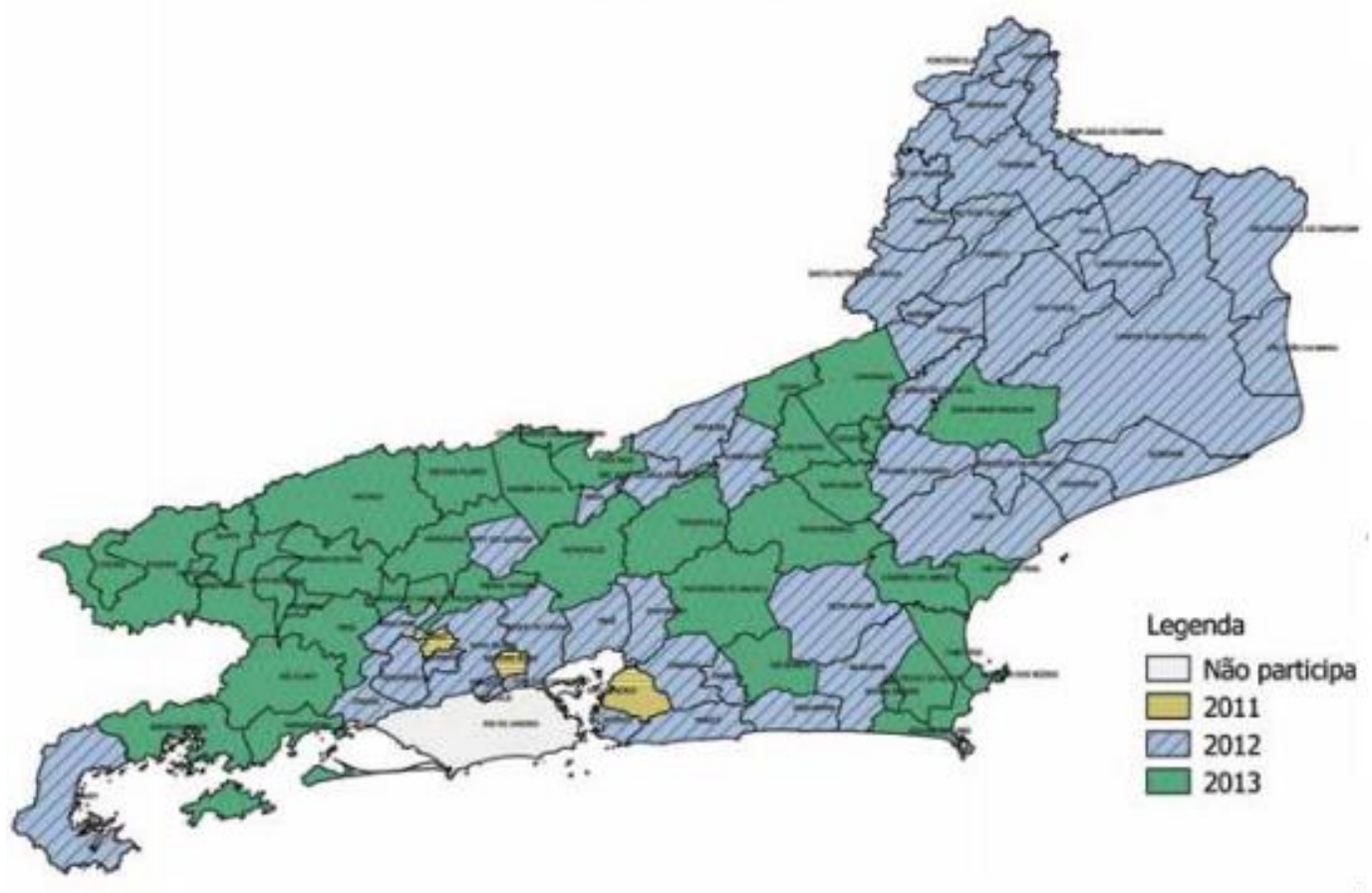

Figura 9- Ano de Adesão dos municípios do Programa Renda Melhor.

Fonte: Guia para a Gestão Municipal do Programa Renda Melhor, 2014, p. 58.

Atualmente, $100 \%$ dos municípios fluminenses habilitados para o PRM aderiram ao Programa, que a exemplo do PBF, possui um instrumento de adesão denominado "Termo de Adesão", igualmente ao modelo adotado pelo Programa Bolsa Família.

Tendo em vista que os municípios são entes federados autônomos, faz-se necessário o estabelecimento de um instrumento de pactuação para a definição de compromissos entre os governos municipais e o Governo do Rio de Janeiro. (Guia para a Gestão Municipal do Programa Renda Melhor, 2014, p. 59).

A adesão ao Programa por parte das Gestões Municipais, implica em assumir compromissos ou atribuições relacionadas a gestão, interlocução e articulação, de forma que as ações sejam integradas entre Estado e municípios, a fim de reduzir a pobreza e a desigualdade das famílias beneficiárias. De acordo com o Guia para a Gestão Municipal do Programa Renda Melhor 2014, p.60):

Nessa perspectiva e considerando o modelo integrado PBF/RENDA MELHOR as coordenações municipais do PBF/CADUNICO assumem o compromisso de realizar o atendimento às famílias beneficiárias do Renda Melhor, bem como a 
priorização do acompanhamento familiar, em articulação com as demais unidades e serviços da Rede SUAS.”

A cópia do Termo de Adesão com o objeto, atribuições das Gestões Municipais e da SEASDH encontra-se disponível nos anexos da presente pesquisa para possibilitar a melhor compreensão do contexto aqui explicitado.

\section{Fluxo Operacional do Programa Renda Melhor}

O PRM possui um modelo operacional que prioriza a integração federativa entre a União, o estado do Rio de Janeiro e os municípios que aderiram ao Programa.

Além disso, conta com o apoio do Centro de Tecnologia da Informação e Comunicação do Estado do Rio de Janeiro (Proderj) e CAIXA como agentes operadores, a CAIXA também como agende pagador e o Ministério Público como agente fiscalizador.

No que se refere aos procedimentos operacionais, o Centro de Tecnologia da Informação e Comunicação do Estado do Rio de Janeiro (PRODERJ) é o órgão do governo do estado que atua como agente operador, desenvolvendo os sistemas de informação e executando mensalmente o processamento das informações de pagamento dos benefícios para envio à CAIXA, assim como elaborar a folha raiz anualmente. O PRSM utiliza de forma intensiva a tecnologia da informação, viabilizada por meio da importante parceria institucional que foi firmada a partir de 2011 com o PRODERJ. Já a CAIXA recebe e valida as informações recebidas do PRODERJ e mensalmente gera a folha de pagamento do Renda Melhor, que é paga em conjunto com os pagamentos dos benefícios do Programa Bolsa Família, por meio do cartão compartilhado do PBF/PRM. Destaca-se, ainda, que o Ministério Público do Estado do Rio de Janeiro, por meio do Acordo de Cooperação $\mathrm{n}^{\mathrm{o}} 5$ firmado com a SEASDH em 2011, assume importante papel na fiscalização das ações previstas no âmbito do Plano Rio sem Miséria, em particular no que se refere ao Programa Renda Melhor, executando diligências, quando necessário, para a apuração de denúncias ou atos ilícitos relacionados ao Programa. (Ana Vieira, Superintendente de Renda de Cidadania)

A figura abaixo mostra o detalhamento das principais etapas do modelo de operação do Renda Melhor. 


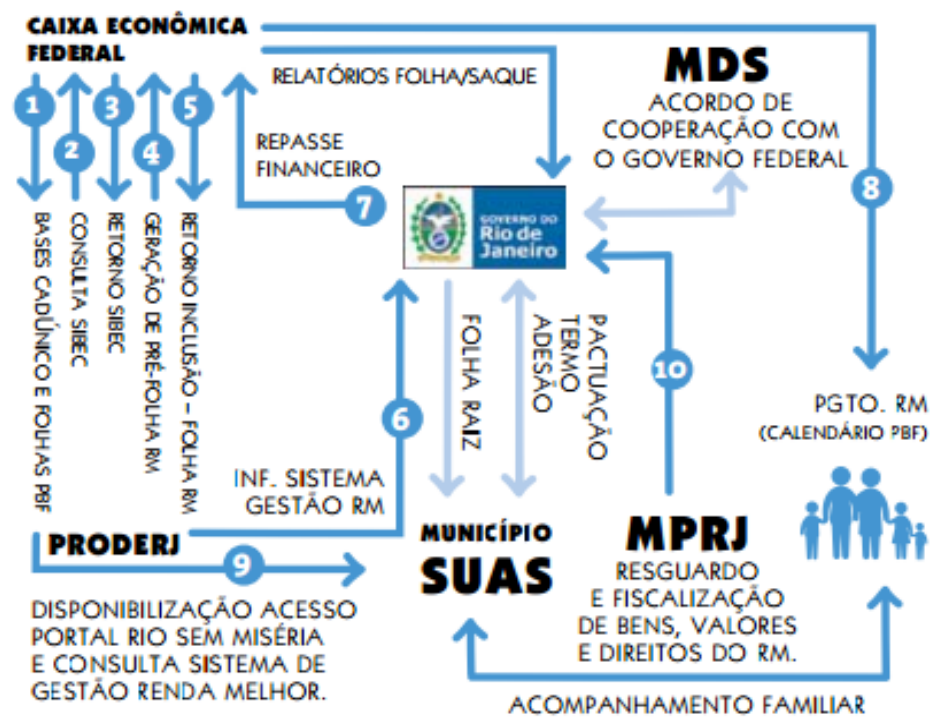

Figura 10- Fluxo Operacional do Programa Renda Melhor.

Fonte: Guia para a Gestão Municipal do Programa Renda Melhor, 2014, p.37.

As informações geradas são disponibilizadas no Portal Rio Sem Miséria e no Sistema de Gestão do Programa Renda Melhor, onde é possível a consulta por parte das Gestões Municipais, a fim de que as informações sejam disponibilizadas para as famílias que buscam atendimento.

O fluxo operacional do Programa inicia-se com a disponibilização das bases municipais do Cadastro Único e das folhas de pagamento municipais do PBF pela CAIXA para o PRODERJ, objetivando a geração da folha mensal do PRM.

Para passar para a etapa seguinte, a família precisa estar cadastrada no Cadastro Único e estar recebendo o PBF. Após, é efetuada a segunda etapa, a “ Consulta do Sistema de Benefícios ao Cidadão - SIBEC”, para verificar a situação da família no PBF. Caso o benefício esteja na situação de liberado, poderá ser gerado o pagamento o pagamento do Renda Melhor. Se o benefício do PBF estiver na situação de bloqueado, suspenso ou cancelado, não será gerado pagamento.

Após ocorre a etapa denominada "Retorno da Consulta SIBEC", com as informações sobre a situação nodo PBF, quando é gerada a "Pré Folha Mensal do PRM”, que é encaminhada para a CAIXA para a verificação das divergências cadastrais (alterações nas informações contidas no Cadastro Único). A última 
etapa é a denominada "Retorno Inclusão - Folha RM", que contém as informações do valor do benefício para o mês corresponde, bem como parcelas retroativas ${ }^{72}$.

Abaixo, podemos observar o fluxo de pagamento do Programa Renda Melhor.

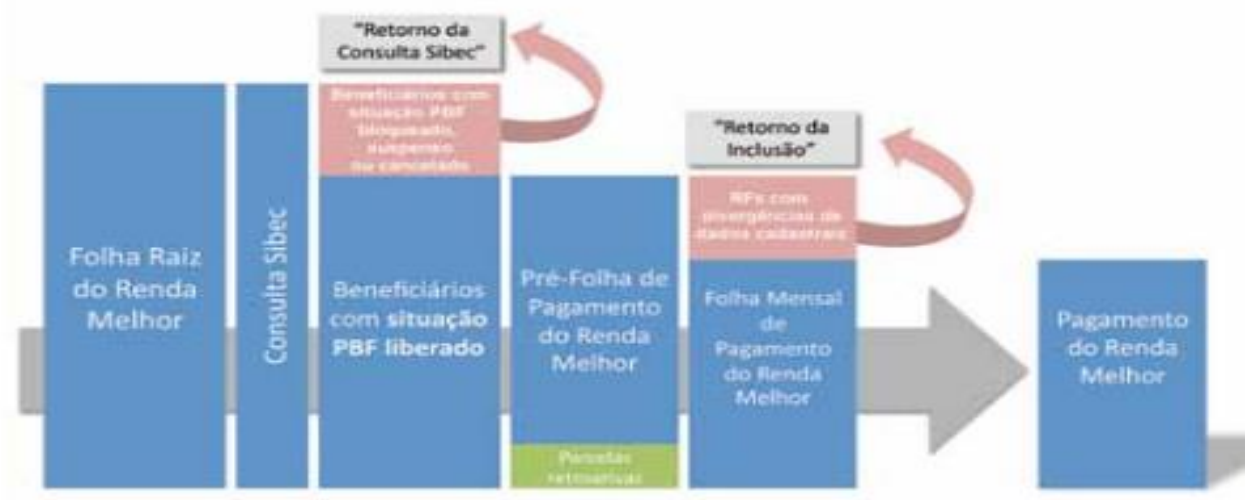

Figura 11- Fluxo de Pagamento - Programa Renda Melhor.

Fonte: Guia para a Gestão Municipal do Programa Renda Melhor, 2014.

Após o encaminhamento da folha mensal de pagamento do PRM, mensalmente, o Governo do Estado do Rio de Janeiro transfere para a CAIXA agente pagador do Programa- o valor total correspondente às parcelas a serem pagas às famílias beneficiárias. $\mathrm{O}$ valor é disponibilizado e pode ser sacado pelo Responsável Familiar por meio do cartão compartilhado PBF/RM, conforme modelo abaixo, ou pelo cartão do Bolsa Família até o recebimento do cartão compartilhado.

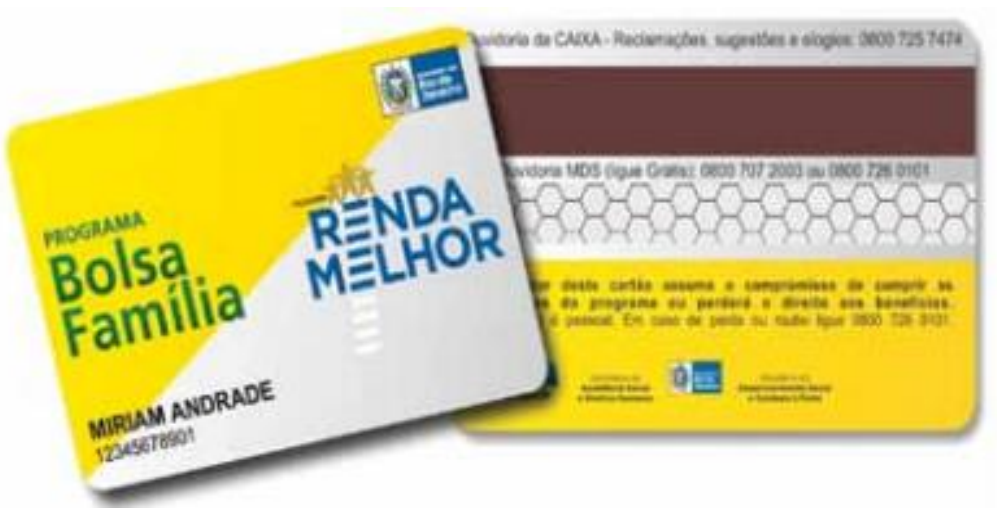

Figura 12- Cartão compartilhado do Programa Bolsa Família e Programa Renda Melhor. Fonte: Guia para a Gestão Municipal do Programa Renda Melhor, 2014, p.50.

${ }^{72}$ No mês em que a família retorna ao fluxo normal de pagamento, o responsável familiar recebe até duas parcelas retroativas: a parcela do mês corrente e até duas parcelas imediatamente anteriores, ou seja, a(s) parcela(s) que não havia(m) sido paga(s) em decorrência da identificação de divergência de dados cadastrais. 
A data de pagamento do benefício para as famílias beneficiárias do Renda Melhor segue o mesmo Calendário de Pagamento estabelecido para o Programa Bolsa Família.

Uma das grandes vantagens do pagamento com o cartão compartilhado é o fato da família poder sacar os dois benefícios em conjunto: no mesmo cartão, na mesma data e no mesmo banco é possível sacar o benefício do Programa Bolsa Família e o benefício do Programa Renda Melhor. Isso facilita muito a vida das famílias, visto que não há necessidade de realizar dois deslocamentos, especialmente para as famílias em situação de vulnerabilidade. (Ana Vieira, Superintendente de Renda de Cidadania)

Por ocasião do saque do benefício, a família recebe o "Comprovante de Pagamento de Benefício Social" com as informações acerca da composição do mesmo: o que refere-se ao PBF e o que refere-se ao PRM, denominado "Pacto Renda Melhor RJ”.

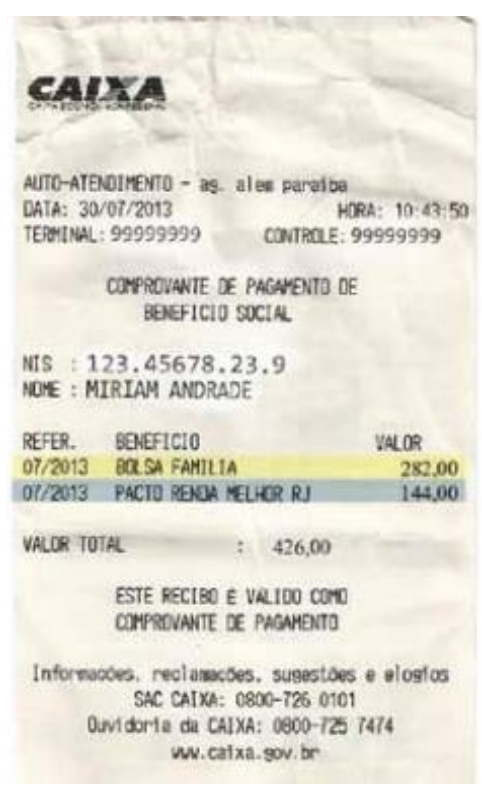

Figura 13- Comprovante de pagamento do PBF e PRM. Fonte: Gestão Programa Renda Melhor, 2014.

Para receber o benefício a família dirige-se a mesma rede e obedecendo ao mesmo calendário de pagamento do PBF. O saque do mesmo é efetuado nas agências da Caixa, lotéricas e correspondentes bancários. 
Atualmente, de acordo com a SEASDH, não há dificuldade para as famílias no que se refere ao saque/pagamento do PRM. A relação com a CAIXA é boa, no sentido de que sempre que há demandas estas são resolvidas por telefone, sem a necessidade de procedimentos mais complexos.

\section{Ferramentas de gestão e monitoramento}

As ferramentas informacionais para a gestão e o monitoramento do Programa Renda Melhor são o Sistema de Gestão do Programa Renda Melhor e o Portal de Informações do Plano Rio Sem Miséria, que passaremos a descrever a seguir.

\section{Sistema de Gestão do Programa Renda Melhor}

Este Sistema foi desenvolvido com o objetivo de registrar e controlar todas as etapas do modelo de operação e auxiliar no processo de gestão e monitoramento do Programa Renda Melhor.

Em setembro de 2013 o módulo de consulta ao Sistema de Gestão do Programa Renda Melhor foi disponibilizado aos 91 municípios, permitindo que a gestão municipal e só técnicos que nela atuam tenham acesso às informações sobre os históricos de pagamentos com o objetivo de informar e orientar de forma precisa as famílias beneficiárias do programa no seu município. (Ana Vieira, Superintendente de Renda de Cidadania)

As Gestões Municipais podem efetuar consultas ás seguintes informações:

- Dados da folha raiz ${ }^{73}$;

- Visualização dos dados referentes à folha de pagamentos do Programa Bolsa Família;

\footnotetext{
${ }^{73}$ A Folha Raiz é a relação de beneficiários do Programa Renda Melhor disponibilizada para os 91 municípios do estado incluídos no programa4 . Para a geração da folha raiz, o PRODERJ utiliza o algoritmo desenvolvido pelo Centro de Pesquisas Sociais da Fundação Getúlio Vargas - FGV -, com a finalidade de identificar as famílias em situação de pobreza extrema, a partir da análise das informações constantes no Cadastro Único. Como resultado desse processamento é apurada a renda estimada per capita das famílias. É importante destacar que a esta renda estimada é somado o valor do beneficio do PBF recebido pelas famílias e após este somatório chega-se à renda presumida per capita mensal das famílias. As famílias cuja renda presumida per capita mensal tenha sido inferior a $\mathrm{R} \$ 100,00$ (cem reais) passam a compor a folha raiz do Programa Renda Melhor
} 
- Informações relacionadas à geração ou não da parcela mensal do programa ("aba" Pagamento por Competência);

- Informações relacionadas às conversões de NIS do RF realizadas após a inclusão da família na folha raiz (“aba” Histórico de NIS do Beneficiário) e;

- As modificações relacionadas à inclusão, alteração e exclusão da família do Programa (“aba Alterações”)

O Módulo de Consulta ao Sistema de Gestão do Programa Renda Melhor, com acesso pelo link http://www.prm.rj.gov.br, é disponibilizado ao Gestor Municipal do Programa Bolsa Família designado formalmente no SIGPBF Sistema de Gestão do Programa Bolsa Família do MDS. Não é possível efetuar o cadastramento de senhas para a equipe da Gestão Municipal, ou seja, somente é possível o cadastramento uma senha por município. Também foram disponibilizadas senhas para a equipe da Coordenação Estadual, de outros setores da SEASDH, parceiros do PRSM e pesquisadores.

Quanto a sua estrutura, o Sistema de Gestão do Programa Renda Melhor está constituído por três módulos: Módulo "Consulta", módulo "Relatórios" e o módulo "Localização de CRAS".

De acordo com as informações contidas no Guia para a Gestão Municipal do Programa Renda Melhor (2014, p.64), módulo "Consulta” são apresentadas detalhadamente as informações dos beneficiários geradoras da folha raiz e o histórico de pagamentos do beneficiário.

\footnotetext{
"Ao expandir a consulta realizada, informando o NIS ou nome do beneficiário, o sistema irá disponibilizar, para cada beneficiário, o histórico de pagamento referente a cada mês, o histórico de NIS e as alterações ocorridas - inclusão, exclusão, alteração de valores para mais ou para menos - em decorrência da geração das folhas raiz de cada ano. Estas informações são de extrema importância para a Gestão Municipal, visto que quando a família beneficiária for procurar atendimento, é possível fornecer as informações sobre o histórico e a situação do benefício". (Ana Vieira, Superintendente de Renda de Cidadania)
}

Na figura abaixo podemos visualizar a tela de consulta por beneficiário, que permite visualizar as suas informações referentes ao benefício do PRM, desde a sua concessão até o mês atual. 


\section{Pesquisa de beneficiário Renda Melhor (Resultado)}

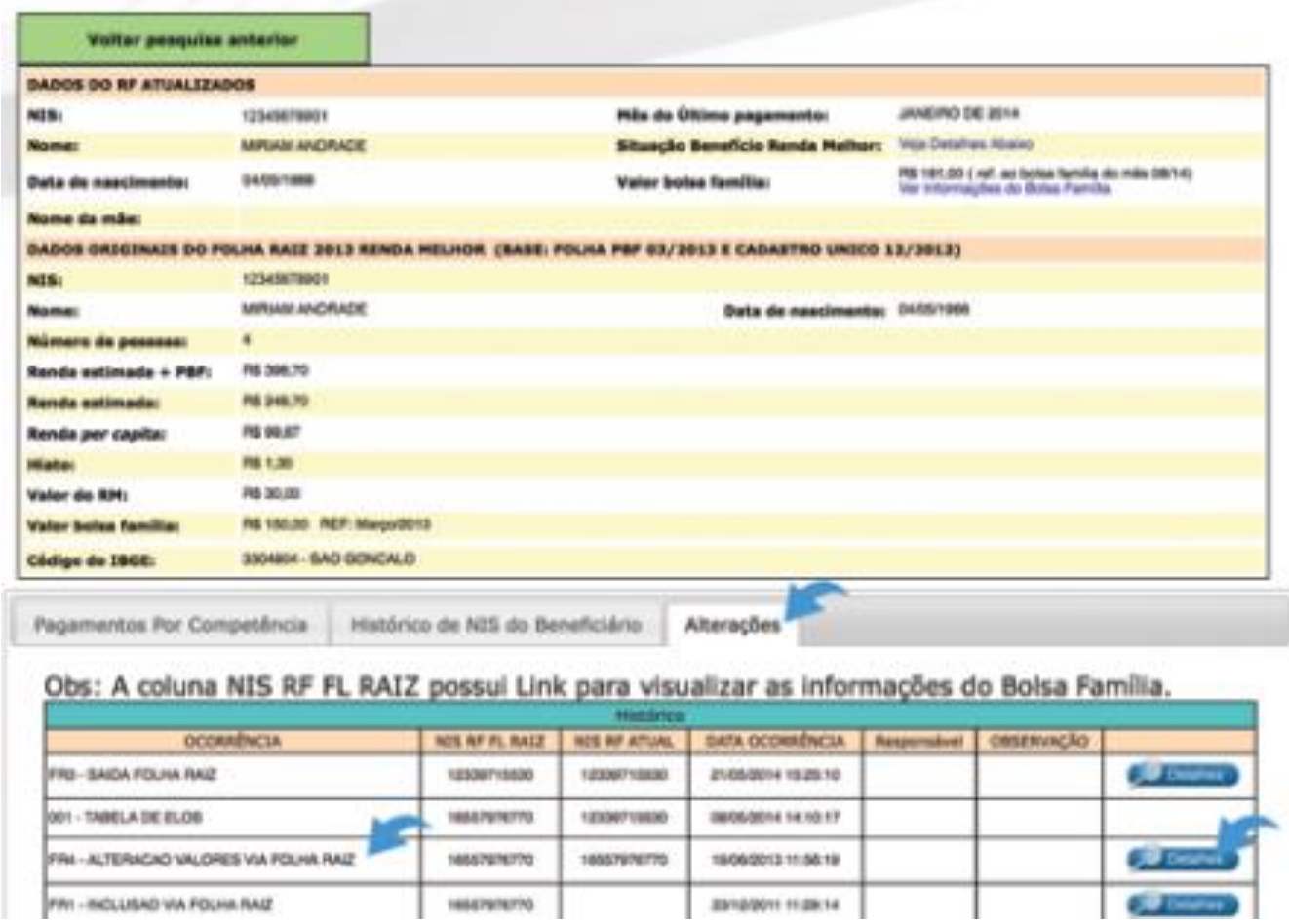

Figura 14- Tela do Sistema de Gestão do Programa Renda Melhor - "Pesquisa de Beneficiário Renda Melhor - Resultado".

Fonte: Guia para a Gestão Municipal do Programa Renda Melhor.

No módulo Relatórios estão disponíveis as folhas raiz do Programa Renda Melhor, geradas anualmente, a Folha Mensal do Renda Melhor e o relatório Distribuição dos Benefícios do Renda Melhor por Faixas de Valor.

“ Os relatórios são muito importantes pois permite aos gestores municipais a extração dos relatórios para acompanhamento mensal, bem como a utilização das informações para cruzamentos, elaboração de relatórios e utilização em apresentações. É uma ferramenta de apoio para a Gestão e esta deve utilizá-los da maneira que achar mais útil e necessário." (Ana Vieira, Superintendente de Renda de Cidadania)

Nesta funcionalidade Localização de CRAS é possível visualizar informações e localização geográfica dos equipamentos da rede SUAS (CRAS, CREAS, CREPOP), informados no Censo SUAS, referentes a qualquer um dos 92 municípios do Estado do Rio de Janeiro.

"As informações referentes à localização dos CRAS, CREAS e CREPOP são de extrema importância para as Gestões Municipais, visto que permite identificar qual o equipamento social que a família está vinculada e encaminhá-las as mesmas para atendimento, evitando deslocamentos desnecessários e despesas 
para as famílias. Além disso é uma importante ferramenta de consulta para a Gestão, sempre que for necessário." (Ana Vieira, Superintendente de Renda de Cidadania)

O acompanhamento à reunião de descentralização do Sistema de Gestão do Programa Renda Melhor para os municípios e o contato com os gestores municipais permitiu evidenciar a percepação da importância da ferramenta para os mesmos. Os Gestores receberam capacitação para o Sistema, tiraram suas dúvidas, bem com expressaram interesse em obter expertise para usá-lo, demonstrando interesse na sua utilização e na importância do mesmo para a Gestão.

\title{
Portal Rio Sem Miséria - Portal PRSM
}

O lançamento do Portal Rio Sem Miséria ocorreu em 04/06/2012, durante a realização do Seminário de Integração Federativa, no Rio de Janeiro e, representou um avanço no desenho de uma ferramenta para o acompanhamento do PRSM.

\begin{abstract}
"Trata-se de uma ferramenta de gerencial, desenvolvida em conjunto com o PRODERJ dentro dos conceitos e tecnologia de Business Intelligence, disponibilizando gráficos pré-formatados, relatórios, e painéis de controle sobre as políticas sociais e respectivas ações dos programas: Plano Rio Sem Miséria Programa Renda Melhor e Programa Renda Melhor Jovem -, Cadastro Único e Programa Bolsa Família. (Ana Vieira, Superintendente de Renda de Cidadania)
\end{abstract}

O objetivo central do Portal consiste em disponibilizar aos gestores municipais informações gerenciais que subsidiem a formulação, a implementação e a avaliação de políticas públicas destinadas à população em situação de vulnerabilidade, com ênfase nas situações de pobreza extrema. É uma ferramenta que permite apoiar e subsidiar a Gestão Municipal.

“A disponibilização do Portal Rio Sem Miséria foi um grande avanço para o PRSM, pois permitiu descentralizar as informações para as Gestões Municipais, a fim de que de posse das mesmas pudessem ser elaboradas políticas municipais para as populações em situação de extrema pobreza. A ferramenta é muito útil visto que relatórios nela contidos não são encontrados em outros locais, nem mesmo nos sistemas do Cadastro Único e do Programa Bolsa Família." (Antonio Claret, Formulador e Gestor do PRSM) 
O Portal é composto por relatórios gerenciais que possibilitam ao gestor municipal realizar o monitoramento e a execução do programa do Programa Renda Melhor, do Cadastro Único e do PBF, com demonstrativos físicos e financeiro, gráficos de cobertura e evolução dos Programas, gráficos com as informações de cobertura por raça e cor, faixa etária, responsável familiar, deficientes, catadores e indígenas/quilombolas.

De acordo com o Guia para a Gestão Municipal do Programa Renda Melhor (2014, p.75):

"Outras informações relacionadas à Situação Cadastral, Ocupação Familiar, Habitação e Educação permitirão à equipe da municipal acompanhar a evolução das famílias do Renda Melhor nessas situações. Os gráficos podem ainda ser utilizados para a geração de relatórios e informes à Secretaria Municipal e demais envolvidos na gestão, de maneira a disponibilizar e divulgar os avanços alcançados pela gestão."

Inicialmente o Portal foi disponibilizado para dez municípios do Estado como parte do projeto pilotos. Os Gestores Municipais utilizaram o Portal por um período e o avaliaram, bem como sugeriram melhorias, Após, os demais 82 municípios do Estado passaram a ter acesso ao PRSM.

Acompanhamos a reunião de apresentação e capacitação dos Portal para os 82 municípios do Estado. Evidenciamos a importância do mesmo para a Gestões Municipais, bem como o interesse dos Gestores em utilizar o Portal, especialmente no que se refere aos relatórios de cobertura e evolução dos Programas.

"É como se os Gestores Municipais sentissem, visualizassem o seu trabalho, visto que as informações são atualizadas mensalmente. Nos gráficos, por exemplo, é possível verificar a evolução da cobertura cadastral, o cadastramento de famílias quilombolas, de catadores. A Gestão municipal sente que seu trabalho está sendo visto, que está dando resultados. Para a Gestão Estadual e para as famílias isso é muito importante." (Antonio Claret, Formulador e Gestor do PRSM)

O Portal do Plano Rio Sem Miséria ganhou o prêmio $e$-Administração Pública na $41^{\mathrm{a}}$ edição do Seminário Nacional de Tecnologia da Informação e Comunicação para a Gestão Pública realizado em Vitória, no Espírito Santo, tendo 
concorrido com outras 80 iniciativas de vários segmentos da Administração Pública.

\title{
4.4. \\ Programa Renda Melhor Jovem (PRMJ)
}

O Programa Renda Melhor Jovem (PRM) é uma estratégia muito importante do PRSM, visto que no estado do Rio de Janeiro as desigualdades educacionais entre os estratos econômicos são acentuadas, conforme vimos anteriormente.

\begin{abstract}
"No estado do Rio de Janeiro, podemos afirmar que as desigualdades educacionais entre as classes sociais são alarmante. Atualmente há um enorme potencial de reprodução dos níveis de desigualdade no campo educacional o que acaba acarretando a ampliação das situações de pobreza e desigualdade." (Luis Gustavo, Superintendente de Gestão de Oportunidades)
\end{abstract}

As afirmações podem ser corroboradas por meio do desempenho do Estado nos indicadores abandono e reprovação, no ensino médio da Rede Pública Estadual de Educação, conforme podemos observar na tabela abaixo.

Tabela 1- Taxas de reprovação e abandono do ensino médio na Rede Pública Estadual de Educação

\begin{tabular}{|l|c|c|c|c|}
\hline \multirow{2}{*}{ Estado } & \multicolumn{2}{|c|}{2010} & \multicolumn{2}{c|}{2011} \\
\cline { 2 - 5 } & Reprovação & Abandono & Reprovação & Abandono \\
\hline Minas Gerais & 13,4 & 8,8 & 13,3 & 10,2 \\
\hline Espírito Santo & 13,2 & 7 & 20,7 & 9,1 \\
\hline Rio de Janeiro & $\mathbf{1 8 , 9}$ & $\mathbf{1 2 , 8}$ & $\mathbf{2 0 , 3}$ & $\mathbf{1 2 , 4}$ \\
\hline São Paulo & 12,6 & 4,5 & 15,4 & 5,3 \\
\hline
\end{tabular}

Fonte: Inep e elaboração da autora.

Observamos que o índice de reprovação é elevado se compararmos com os demais estados da região sudeste, bem como ampliou-se no prazo de um ano. Com relação ao abandono da escola, observamos que o mesmo é elevado se realizarmos a mesma comparação com os demais estados. 
Ao realizamos um estudo com os quintis de pobreza, constatamos que nos $20 \%$ mais pobres do Estado, apenas $8 \%$ dos jovens conseguem concluir o ensino médio. Ainda com relação aos jovens mais pobres, $68 \%$ não conseguem concluir o ensino fundamental até 2011 e 51\% destes jovens com idade de 19 a 24 anos até 2011 não haviam atingido o ensino médio.

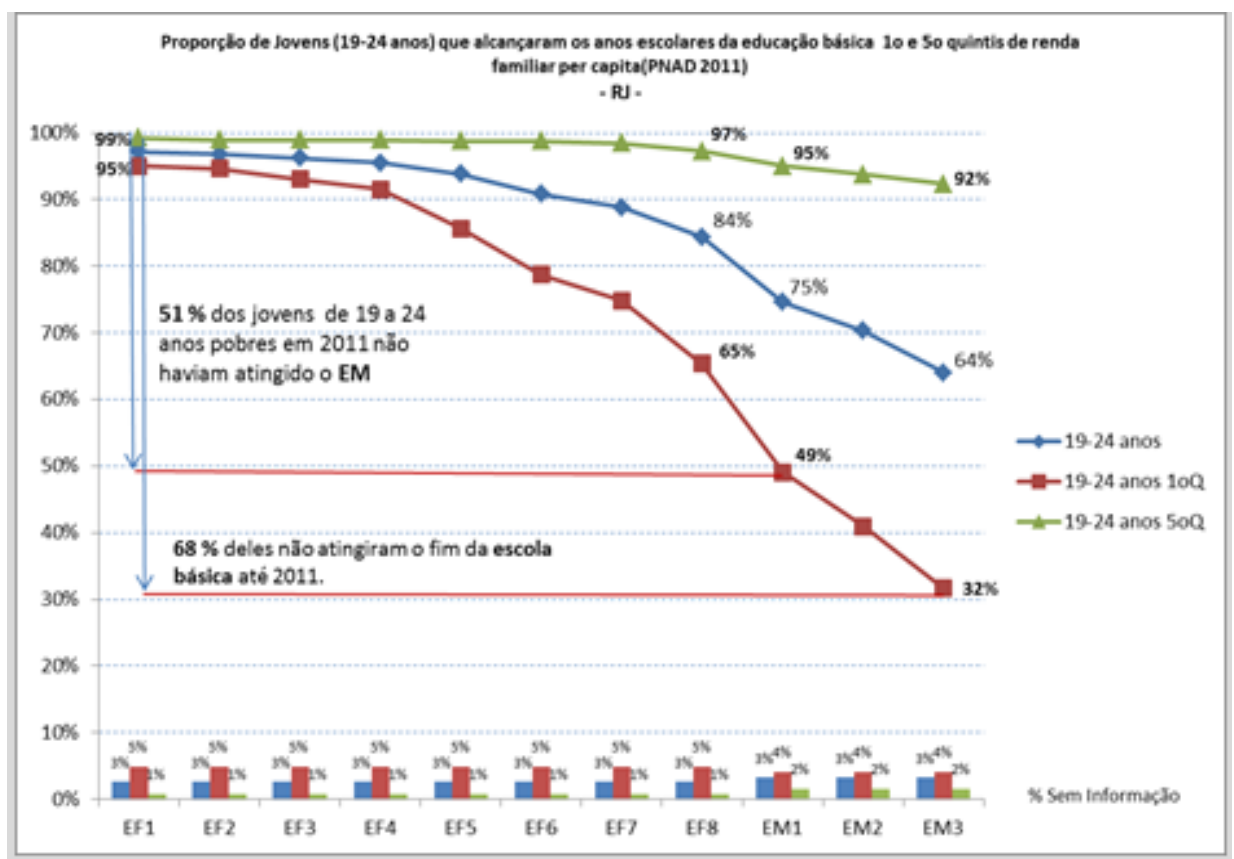

Gráfico 6- Acesso à educação pelos quintis de pobreza no RJ. Fonte: PNAD, elaboração da autora.

Esses indicadores demonstram que o Estado vem no processo de piora dos indicadores até o ano de 2011, sendo necessário a intervenção por meio de uma política pública que consiga reverter os indicadores e com isso seja proporcionado o acesso dos adolescente e jovens à Educação.

"É no cenário de desigualdade educacional presente no Estado do Rio de Janeiro que surge a segunda estratégia do Plano Rio Sem Miséria, o Programa Renda Melhor Jovem, objetivando reverter o cenário de profunda desigualdade educacional.” (Luis Gustavo, Superintendente de Gestão de Oportunidades)

A segunda estratégia do Plano Rio Sem Miséria, portanto é o Programa Renda Melhor Jovem - PRMJ, que se destina as jovens pertencentes às famílias do Programa Renda Melhor ou do Programa Cartão Família Carioca, que: 
- Estejam matriculados na rede de ensino médio regular ou profissionalizante da SEEDUC;

- Tenham ingressado no ensino médio com até 18 anos incompleto; $\mathrm{e}$

- Tenham assinado termo de adesão e validado suas contas no Banco do Brasil.

Ou seja, para pertencer ao Programa Renda Melhor, os jovens necessitam que suas famílias sejam cadastradas no Cadastro Único, recebam benefício do PBF e do Programa Renda Melhor e/ do Programa Cartão Família Carioca, conforme podemos observar na figura abaixo.

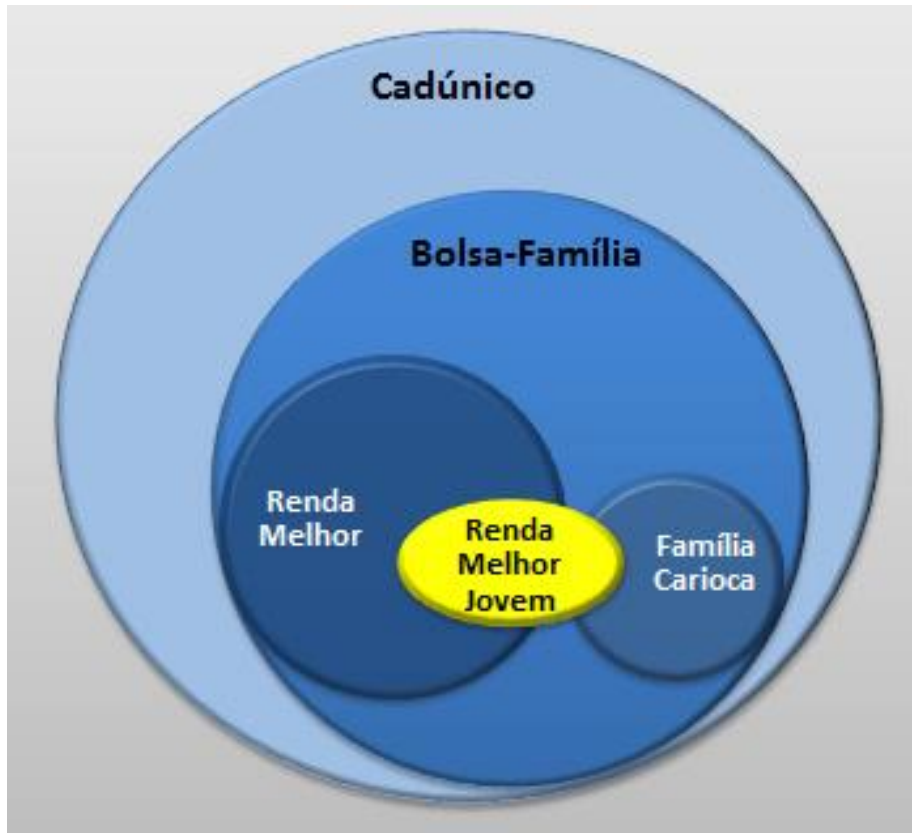

Figura 15- Quem é o jovem do Programa Renda Melhor Jovem. Fonte: Seasdh.

Os objetivos do Programa Renda Melhor Jovem consistem essencialmente na melhoria das condições de vida das famílias e dos jovens por meio do acesso á educação:

i) promover o desenvolvimento dos jovens, com foco na erradicação da pobreza extrema através do investimento em capital humano;

ii) incentivar a permanência e bom desempenho do jovem na escola; 
iii) contribuir para o aumento das taxas de aprovação e conclusão do ensino médio no Estado do Rio de Janeiro e;

iv) contribuir para a redução dos determinantes das vulnerabilidades da juventude.

Com relação aos objetivos do Programa, o Superintendente de Gestão de Oportunidades ressalta:

"Ao decompormos os objetivos do Programa Renda Melhor Jovem, podemos afirmar que eles consistem em inicialmente atuar sobre a dimensão intergeracional de reprodução da pobreza, enfrentando suas causas estruturais através do investimento em capital humano; incentivar a permanência e o bom desempenho do jovem na escola e reduzir a defasagem idade-série; contribuir para o aumento das taxas de aprovação e conclusão do Ensino Médio no Estado do Rio de Janeiro; apoiar financeiramente as iniciativas dos jovens quando terminarem o ensino médio (poupança)e; enfrentar uma das principais barreiras a inclusão qualificada no mercado de trabalho, que é a baixa escolaridade das pessoas em situação de pobreza associada à ausência de oportunidades".(Luis Gustavo, Superintendente de Gestão de Oportunidades)

A implantação o PRMJ nos municípios fluminenses teve seu início por ocasião da implantação o Plano Rio Sem Miséria no Estado, juntamente com o Programa Renda Melhor.

Inicialmente, em três municípios do Estado: Belford Roxo, Japeri e São Gonçalo foi realizado um piloto do Programa, objetivando verificar o desempenho do mesmo nos locais, assim como posteriores melhorias, com base neste desempenho antes do mesmo ser expandido para os demais municípios do Estado.

“A opção pela realização de um projeto piloto para a implantação do Programa inicialmente nos três municípios em que foi implantado o PRSM nos deus subsídios para realizar alguns aperfeiçoamentos no fluxo operacional por ocasião da expansão do Programa nos demais municípios. Se formos analisar a receptividade do Programa nos municípios, observamos que ela foi muita boa." (Luis Gustavo, Superintendente de Gestão de Oportunidades)

A partir de 2012, o Programa foi expandido para mais 49 municípios do Estado, totalizando 52 municípios. Em 2013, o PRM atingiu a totalidade dos municípios do Rio de Janeiro, conforme podemos observar no quadro abaixo. 


\begin{tabular}{|c|c|c|c|c|}
\hline 2011 & 2012 & 2012 & 2012 & 2013 \\
\hline BELFORD ROXO & BELFORD ROXO & NOVA IGUAÇU & SUMIDOURO & TODOS OS \\
\hline JAPERI & JAPERI & PARACAMBI & TANGUA & MUNICÍPIOS \\
\hline SÃO GONÇALO & SÃO GONÇALO & PARATI & TRAJANO DE MORAIS & \multirow{18}{*}{92 MUNICÍPIOS } \\
\hline \multirow{17}{*}{3 MUNICÍPIOS } & MAGÉ & PATY DO ALFERES & MIRACEMA & \\
\hline & ARARUAMA & PORCIUNCULA & CONÇEIÇÃO DE & \\
\hline & AREAL & QUEIMADOS & MACABU & \\
\hline & CAMBUCl & QUISSAMA & BOM JESUS DO & \\
\hline & CAMPOS DOS & SÃO FRANCISCO DE & ITABAPOANA & \\
\hline & GOYTACAZES & ITABAPOANA & LAJE DO MURIAÉ & \\
\hline & CARAPEBUS & SÃO JOÃO DA BARRA & SÃO FIDÉLIS & \\
\hline & CARDOSO MOREIRA & SÃO JOÃO DE MERITI & ITALVA & \\
\hline & DUQUE DE CAXIAS & SÃO JOSÉ DE UBA & VARRE-SAI & \\
\hline & GUAPIMIRIM & \multirow{4}{*}{$\begin{array}{l}\text { SÃO JOSÉ DO VALE } \\
\text { DO RIO PRETO } \\
\text { SÃO SEBASTIÃO DO } \\
\text { ALTO }\end{array}$} & NATIVIDADE & \\
\hline & ITABORAI & & ITAOCARA & \\
\hline & ITAGUAI & & \multirow{2}{*}{$\begin{array}{l}\text { SANTO ANTÔNIO DE } \\
\text { PÁDUA }\end{array}$} & \\
\hline & MARICA & & & \\
\hline & MESQUITA & SAPUCAIA & MACAÉ & \\
\hline & NILOPOLIS & SAQUAREMA & APERIBÉ & \\
\hline & NITEROI & SEROPEDICA & ITAPERUNA & \\
\hline & RIO DE JANEIRO & SILVA JARDIM & 52 MUNICÍPIOS & \\
\hline
\end{tabular}

Quadro 6 - Ano de implantação o PRMJ nos municípios fluminenses. Fonte: SEASDH.

A seguir traremos alguns aspectos importantes sobre o PRMJ que visam auxiliar na análise do Plano e seu potencial para a redução da pobreza.

\section{Pagamento de benefícios do PRMJ}

O pagamento do benefício do Programa apresenta especificidades, visto que se trata de uma poupança para os jovens, que terão direito a recebê-la após concluir o ensino médio. Para receber o valor do PRM J os jovens deverão:

- Obter aprovação em cada ano letivo com ou sem dependência (no ano de conclusão não é permitida a dependência);

- Realizar ao menos 2 avaliações bimestrais por ano - Saerjinho SEEDUC; e

- Participar da avaliação anual do Sistema de Avaliação da Educação do Estado do Rio de Janeiro - SAERJ/SEEDUC.

As condicionalidades do Programa expressam os seus objetivos fundantes que consistem no reforço do acesso à educação, criando condições para que os alunos tenham o incentivo do recurso financeiro para concluir o ensino médio sem distorção de série-idade. 
"O Programa Renda Melhor tem a expectativa de proporcionar um futuro melhor para os jovens, por meio da educação formal e a de um outro futuro, que incorpora um certo ajuste de expectativas ao universo simbólico vivido pela família. Ou seja, por meio dos depoimentos das famílias por ocasião do lançamento do Plano, bem como pelo acompanhamento das famílias beneficiárias, detectamos uma grande expectativa das famílias em acessar a educação para mudar os rumo das vidas. Os responsáveis familiares, bem como os jovens acreditam que os seus filhos estudando, os mesmos terão oportunidade de melhorar a sua condição de vida, rompendo com o ciclo de pobreza." (Antônio Claret, Formulador e Gestor do PRSM)

Os valores depositados em conta-poupança aberta no Banco do Brasil, condicionados à aprovação do jovem a cada ano variam a cada série conforme podemos observar abaixo:

- $\quad \mathrm{R} \$ 700,00$ se o jovem concluir $1^{\mathrm{a}}$ série do ensino médio;

- $\quad \mathrm{R} \$ 900,00$ se o jovem concluir a $2^{\mathrm{a}}$ série do ensino médio;

- $\mathrm{R} \$ 1.000,00$ se o jovem concluir a $3^{\mathrm{a}}$ série do ensino médio

- $\mathrm{R} \$ 1.200,00$ para o caso dos alunos que cursarem o ensino médio profissionalizante, que tem a duração de 4 anos.

Para os jovens que realizarem a prova do Exame Nacional do Ensino Médio-Enen e obterem desempenho o desempenho no Programa, superior a 50\%, receberão o prêmio de Conclusão Qualificada, no valor $\mathrm{R} \$ 500,00$ ao final do Ensino Médio.

O jovem recebe o valor do benefício na conta-poupança aberta em seu nome no Banco do Brasil. Para isso, ele recebe um cartão com a logo marca do Programa Renda Melhor, conforme podemos ver na figura abaixo. 


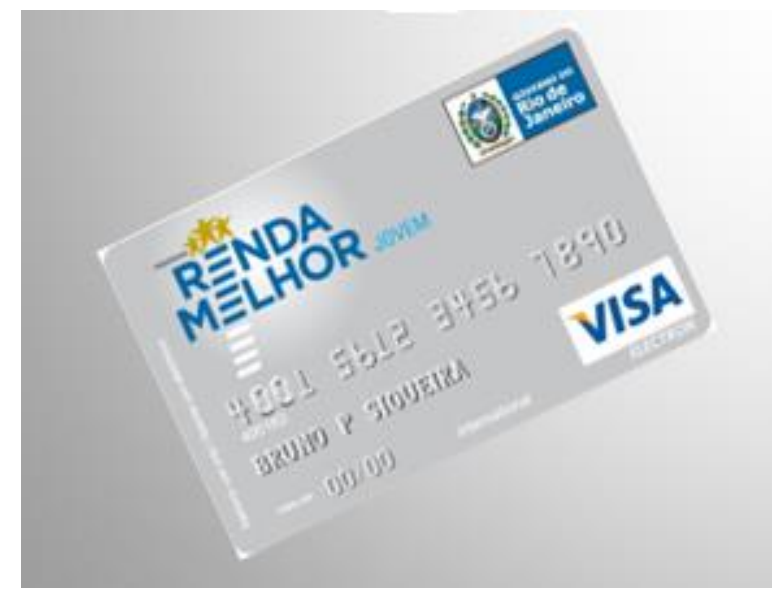

Figura 16- Cartão do Programa Renda Melhor Jovem. Fonte: SEASDH.

"O fato do jovem receber um cartão em seu nome é muito importante. Temos presenciado que a inclusão bancária por mais que pareça algo simples para o cotidiano de muitas pessoas, para os jovens em situação de pobreza extrema é algo muito importante. Significa que estão sendo incluídos na sociedade, estão acessando a documentação civil básica (carteira de identidade) e CPF, pois necessitam desta documentação para a abertura da conta." (Luis Gustavo, Superintendente de Gestão de Oportunidades)

O jovem tem direito a sacar apenas $30 \%$ do valor do benefício depositado a partir de março do ano seguinte à conclusão do ano que está cursando, caso seja aprovado e não tenha desistido. Os demais $70 \%$ formam uma poupança e somente poderão ser sacados por ocasião da conclusão do ensino médio conforme podemos observar na figura abaixo.

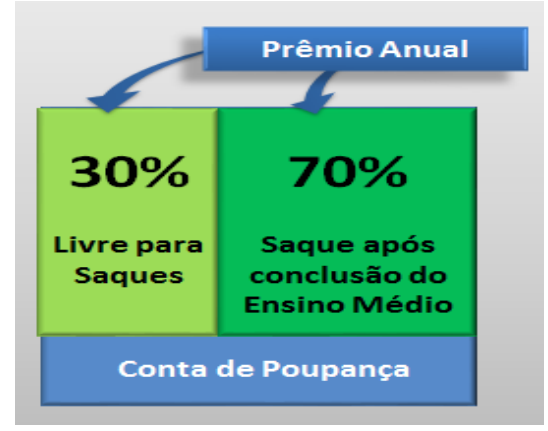

Figura 17- Descrição do \% de saque para pagamento do PRMJ. Fonte: SEASDH.

Caso o jovem seja aprovado no $1^{\circ}$ e no $2^{\circ}$, assim como no $3^{\circ}$ do ensino profissionalizante com dependência, se for aprovado posteriormente, fará jus ao 
benefício. Não poderá ser aprovado com dependência se estiver no ano conclusivo ( $3^{\circ}$ ou $4^{\circ}$ ano, dependendo do caso). Se o jovem desistir, não terá o direito de receber os $30 \%$, nem o valor da poupança acumulada (70\%).

O valor do benefício que fica na poupança (70\%) renderá juros (taxa mensal de poupança) até o recebimento do mesmo e, ao final do ano conclusivo o jovem poderá sacar o valor total da poupança que lhes é devido. Todos os saques são efetuados por meio do cartão magnético.

Atualmente, 41.063 jovens são elegíveis para o Programa Renda Melhor Jocwm, o que significa que estes jovens preenchem os requisitos para o recebimento do benefício do Programa.

\section{Fluxo Operacional do PRMJ}

O PRMJ é executado em conjunto entre a Secretaria de Estado de Assistência Social e Direitos Humanos (SEASDH) e Secretaria de Estado de Educação (SEEDUC), com estabelecimento de um fluxo operacional com atribuições definidas para cada uma.

O agente financeiro do Programa é o Banco do Brasil (BB), responsável pela emissão dos cartões bancários, cadastramento de senhas e o pagamento dos benefícios. Já a gestão do sistema do PRMJ está sob a responsabilidade do Centro de Tecnologia da Informação e Comunicação do Estado do Rio de Janeiro (PRODERJ).

Abaixo podemos visualizar o fluxo do PRMJ, com a descrição das etapas. Observa-se que a primeira etapa consiste na identificação do público alvo do Programa, por meio do acesso aos relatórios das famílias cadastradas no Cadastro Único, beneficiárias do PBF, do Programa Renda Melhor e do Programa Cartão Família Carioca, conforme for o caso. 


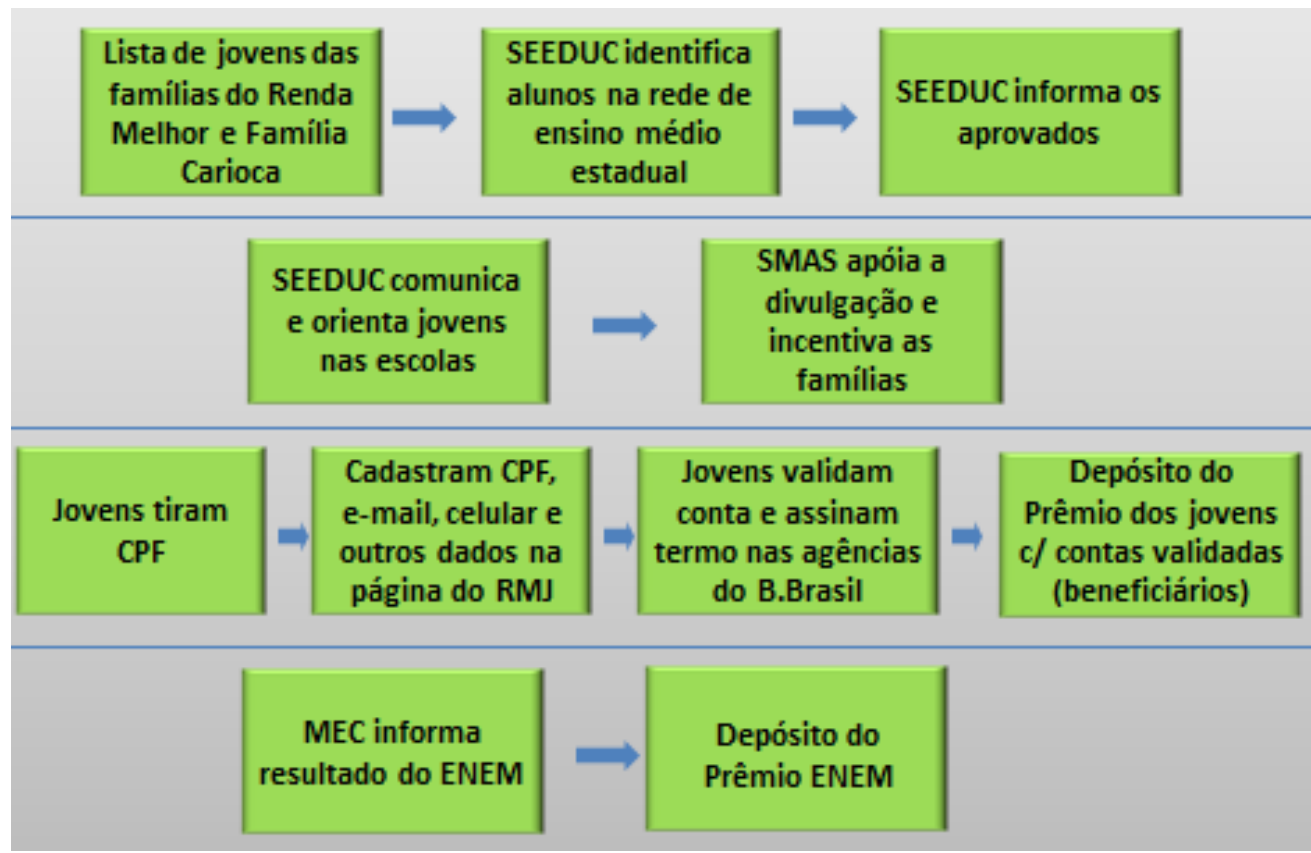

Figura 18- Fluxo operacional do PRMJ.

Fonte: SEASDH, 2014.

Após identificados os jovens com perfil, as informações são envidadas para a SEEDUC para que seja possível localizar os alunos nas escolas. Então, os alunos são informados do direito a receber o benefícios, bem como orientados a obter o Cadastro da Pessoa Física e a carteira de identidade ( para os que não possuem), a fim de poder efetuar a abertura das suas contas correntes.

A abertura das contas correntes é efetuada no Banco do Brasil, mediante preenchimento de documentação exclusiva com identificação de que se trata de conta especifica para o recebimento do benefício do PRMJ.

O apoio e acompanhamento das Secretarias Municipais de Assistência Social para a atualização cadastral no Cadastro Único, bem como acompanhamento do benefício do PBF e do PRM e no caso do município do Rio de Janeiro é muito importante, bem como no momento em que os jovens identificados como potenciais beneficiários devem ser mobilizados a fim que de seja efetuada a abertura das contas no Banco do Brasil.

"O trabalho das Secretarias Municipais de Assistência Social é decisivo para que as famílias estejam com os seus cadastrados atualizados, objetivando identificar a escola onde as alunos estudam bem como a sua série. É importante também que o benefício do PBF e o benefício do PRM ou do Cartão Família Carioca esteja liberado para que os jovens possam ser publico potencial do PRMJ. Fundamental 
também são as parcerias estabelecidas com as Secretarias de Assistência Social sentido de mobilizar as famílias para que as mesmas efetuem a abertura das contas no Banco do Brasil. De nada adianta identificar os beneficiários do Programa se os mesmos não efetuar a abertura da conta para que o benefício seja sacado pelos beneficiários." (Luis Gustavo, Superintendente de Gestão de Oportunidades)

Após a abertura da conta corrente é importante o acompanhamento junto ás famílias para que os jovens possam ser orientados no sentido de que para receber o benefício devem ser aprovados bem como não podem desistir dos estudos. Nesse sentido, também é muito importante o trabalho conjunto da Educação e da Assistência Social.

Também é importante a orientação junto às famílias para que os jovens possam sacar os benefícios, apesar de que, de acordo com o Superintendente de Gestão de Oportunidades, Luis Gustavo, não há casos de jovens que não tenham sacado os benefícios, a partir do momento que o mesmo é disponibilizado na conta corrente.

\begin{abstract}
"Depois que os jovens tomam conhecimento do funcionamento do PRMJ não há dificuldades para que os mesmo compreendam este funcionamento bem como realizem todos os procedimentos necessários para efetuar a abertura de contas e o saque dos benefícios". (Luis Gustavo, Superintendente de Gestão de Oportunidades)
\end{abstract}

Pode-se classificar o fluxo operacional do PRMJ como complexo, pela variedade dos segmentos envolvidos, bem como pelo número de ações a serem executadas até que o processo esteja concluso. Cabe destacar, que o mesmo vem sendo constantemente alterado a fim que possa se tornar mais célere e simplificado, objetivando beneficiar especialmente as famílias.

\footnotetext{
“ O PRMJ tem passado por inúmeras alterações especialmente no que se refere ao seu fluxo operacional, visto que dificuldades no que se refere a algumas etapas especialmente no processo de abertura de contas, haja visto que o Banco do Brasil não possui, a exemplo da CAIXA, uma plataforma social para o atendimento específico de programas sociais. Teve que ocorrer uma adaptação no processo de abertura de contas e no pagamento dos benefícios". (Antonio Claret, Formulador e Gestor do PRSM)
} 
Até a conclusão do trabalho de campo da presente pesquisa, as mudanças no Programa não haviam sido definidas e implementadas, ou seja, ainda estavam em discussão, por isso não efetuamos o registro das mesmas.

Tendo como base o fluxo operacional do Programa, algumas situações fazem com que os beneficiários sejam desligados do Programa. A seguir são elencadas as situações:

1. Reprovação por desempenho ou faltas;

2. Fraude na prestação de informações ao Programa;

3. Desligamento por ato voluntário do beneficiário ou determinação judicial;

4. Alteração cadastral que implique em inadequação ao Programa;

5. Falta injustificada na prova anual do Sistema de Avaliação da Educação do Estado (SAERJ);

6. Realização de menos de dois terços $(2 / 3)$ das avaliações bimestrais estaduais - SAERJINHO - por ano;

7. Inclusão indevida no programa;

8. Saída da Rede Estadual Regular de Ensino Médio;

9. Ficar em dependência no último ano do Ensino Médio; e

10. Prestação deliberada de informações incorretas.

Sempre que um beneficiário dor desligado do Programa, receberá comunicação prévia sobre o desligamento, bem como terá oportunidade de recorrer da mesma. Tal procedimento é necessário pois dá oportunidade para os beneficiários justificarem e terem respaldo em algumas situações, impedindo que os mesmos saiam do Programa indevidamente.

Os canais de comunicação dos beneficiários para que os mesmos possam realizar interlocução com a área gestora do Programa consistem em:

i) Homepage do Renda Melhor Jovem: concentra todas as informações de consulta que os alunos precisam sobre o Programa. É um instrumento de busca passiva, pois depende do interesse dos 
alunos em buscar informação. O meio de acesso é o seguinte endereço: http://www.rendamelhorjovem.rj.gov.br;

ii) Facebook: por meio de uma fanpage, os alunos do Renda Melhor Jovem sabem das novidades, oportunidades e tiram dúvidas sobre cada etapa que precisam cumprir para receber os depósitos. O acesso ao Facebook pode ser efetuado por meio de https://ptbr.facebook.com/ ProgramaRendaMelhorJovem;

iii) Mailing list: todo aluno do Renda Melhor Jovem informa seu email quando entra para o Programa. É a forma de comunicação usada para enviar as informações mais individualizadas e detalhadas;

iv) Mensagens de Celular SMS: um serviço contratado de mensagens de celular encurta de forma eficiente a distância entre a equipe e os alunos do Renda Melhor Jovem; E

v) Contato via telefone para beneficiários e para as Gestões Municipais, bem como acesso a Ouvidoria da SEASDH.

Com ferramenta de acesso para as Gestões Municipais é disponibilizada uma página de acesso com consulta pública, contendo as principais informações sobre o Programa bem como a lista de beneficiários do Programa por município. A tela do Sistema de consulta ao PRMJ pode ser visualizada na figura abaixo.

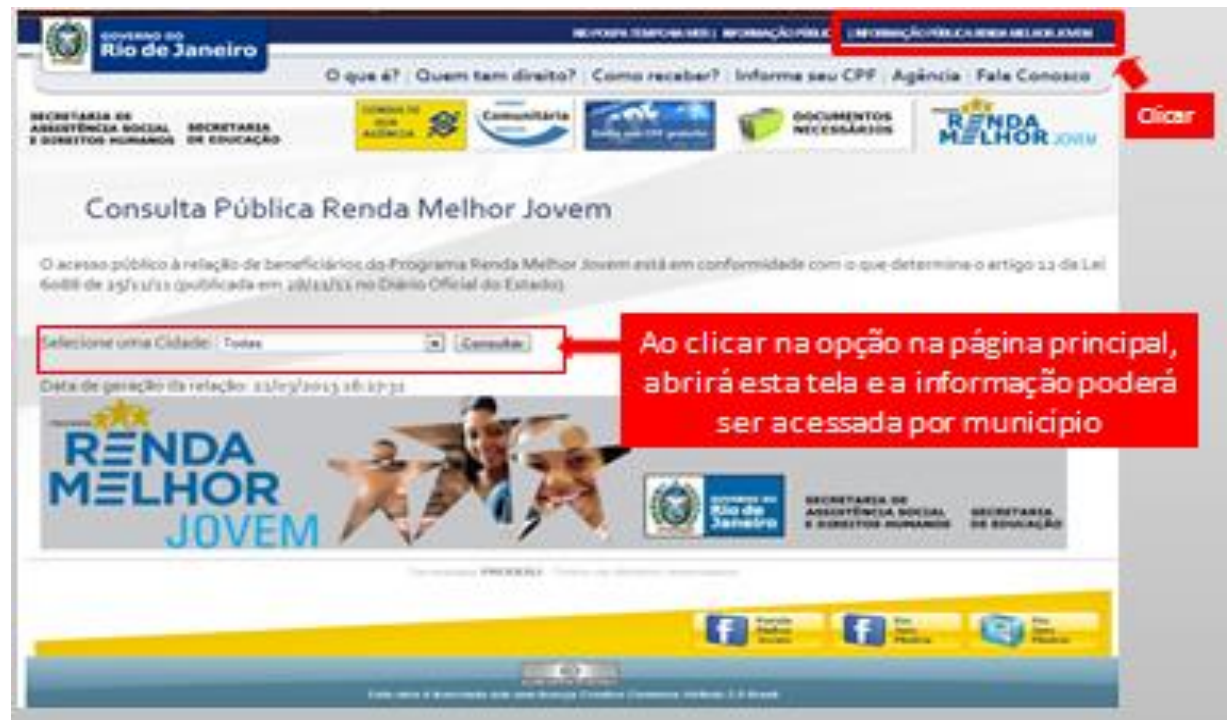

Figura 19- Tela de acesso ao PRMJ para as Gestões Municipais. Fonte: SEASDH. 
De acordo com as Gestões Municipais, conforme podemos observar em reuniões e capacitações realizadas junto às Gestões Municipais, bem como em reuniões da Comissão Integestores Bipartite- CIB foi possível observar que a disponibilização das informações por meio do Sistema de Consulta Pública do Renda Melhor Jovem é de extrema importância, pois serve de subsidio para o atendimento as famílias.

\title{
Integração de Oportunidades no PRMJ
}

Além do pagamento de benefícios financeiros o Programa Renda Melhor Jovem prevê outras estratégias, especialmente no que se refere a integração com outras estratégias do PRSM, com o PBF, bem como o acesso a outras políticas públicas.

\begin{abstract}
"A diretriz central do PRMJ consiste na integração por meio da ampliação das capacidades e oportunidades dos jovens beneciários e isso não é garantido apenas pelo repasse do benefício financeiro, mas sim pelo modo como esse benefício é repassado, ou seja, em forma de poupança para que o jovem possa ter um valor financeiro a fim de iniciar uma faculdade ou mesmo tornar-se um pequenos empreendedor após concluir o ensino médio, bem pelo conjunto de ações visando a integração com as outras estratégias do PRSM: com o PRM, com o GOES; com o PBF e com outras políticas públicas". (Luis Gustavo, Superintendente de Gestão de Oportunidades)
\end{abstract}

$\mathrm{Na}$ figura abaixo podemos observar a integração do Programa Renda Melhor com as demais estratégias do Plano Rio sem Miséria. 


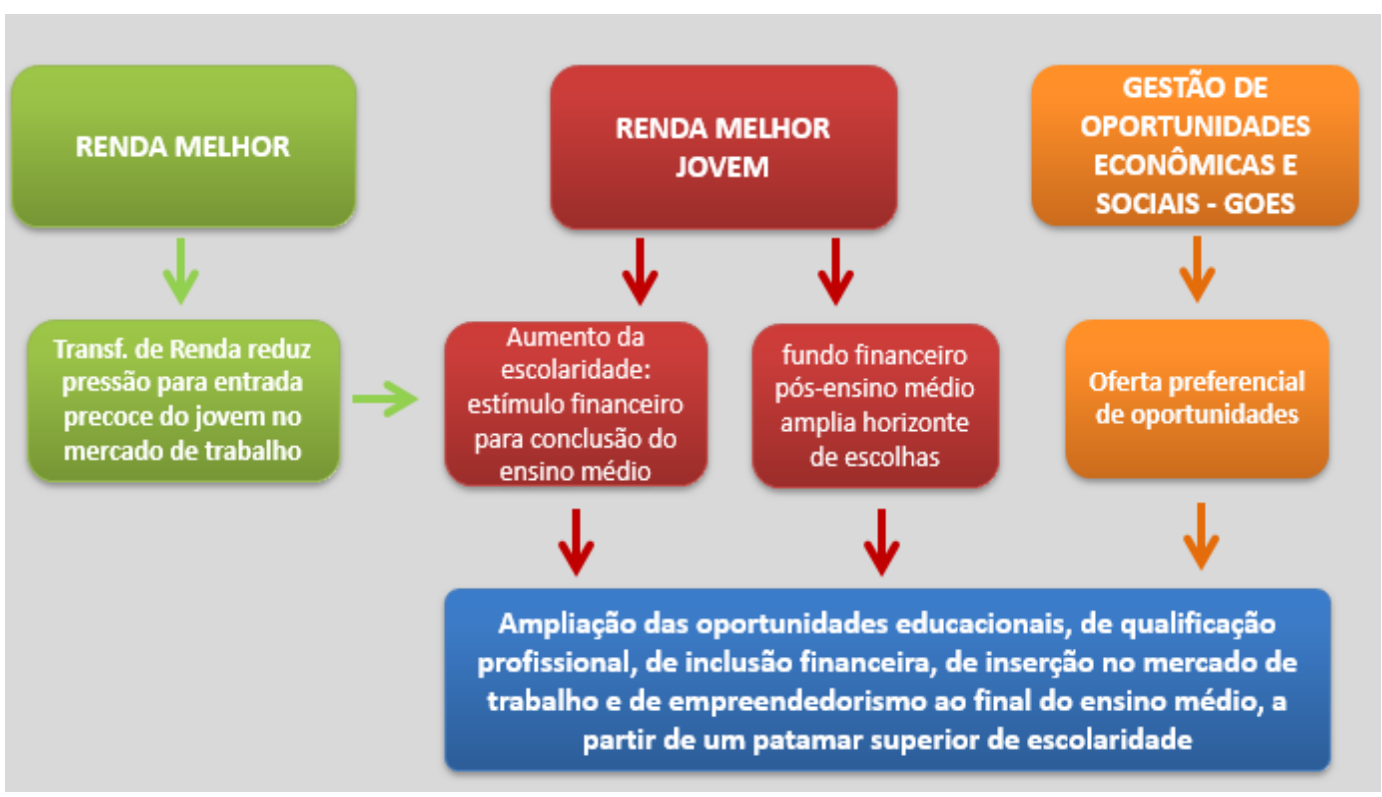

Figura 20- Integração entre o PRMJ e demais estratégias do Plano Rio Sem Miséria. Fonte:SEASDH.

No que se refere ao Programa Renda Melhor objetiva-se que por meio do repasse de recursos financeiros às famílias, complementando o benefício do PBF, o patamar de renda para as necessidades básicas seja ampliado, fazendo com que as pessoas que compõem o grupo familiar tenham condições de se sustentar reduzindo a pressão para a entrada precoce do jovem no mercado de trabalho.

\begin{abstract}
"Um dos principais motivos para a evasão escolar reside na ausência de renda por parte das famílias, que acabam pressionando o jovem a sair da escola para trabalhar a fim de ajudar na composição da renda familiar e no consequente sustento da família. O complemento do Programa Renda Melhor auxilia na ampliação da renda das famílias fazendo com que a mesma consiga sanar suas necessidades básicas e dessa maneira o jovem não é pressionado a sair da escola para trabalhar. Há outros casos em que o aluno não sai da escola, mas acaba sendo reprovado por faltas ou ainda por não conseguir acompanhar o conteúdo em função de trabalhar. Ambas as situações são comuns no estado do Rio de Janeiro, de acordo com a SEEDUC, por isso o baixo desempenho do Estado nos indicadores de educação." (Luis Gustavo, Superintendente de Gestão de Oportunidades)
\end{abstract}

Sobre o PRMJ suas estratégias e seus objetivos, já tivemos oportunidade de discutir largamente o assunto no decorrer deste tópico. Porém, é sempre importante destacar que ambas estratégias estão conectadas em função da prerrogativa do Programa não visar apenas o repasse do benefício financeiro, mas sim num conjunto ampliado de acesso a oportunidades econômicas e sociais, 
objetivando a ampliação das capacidades dos jovens beneficiários e de suas famílias.

Com relação a integração entre o Programa Renda Melhor Jovem e a Gestão de Oportunidades Econômicas e Sociais, o objetivo central reside na oferta de oportunidades para os jovens beneficiários, ou seja, este público é prioridade da estratégia em função da situação de vulnerabilidade, identificada pela situação de vulnerabilidade que estas famílias se encontram, visto que trata-se de público em situação de extrema pobreza.

\footnotetext{
"A integração entre o Programa Renda Melhor Jovem e o GOES visa a ampliação não somente das oportunidades educacionais, mas de um conjunto de oportunidades que incluem a qualificação profissional, de inclusão financeira, de inserção no mercado de trabalho e de empreendedorismo ao final do ensino médio, a partir de um patamar superior de escolaridade, visto que nesta faixa de renda apenas $8 \%$ dos jovens conseguem concluir o ensino médio". (Luis Gustavo, Superintendente de Gestão de Oportunidades)
}

A integração com outras políticas públicas refere-se ao acesso as oportunidades econômicas e sociais no território, ou seja, durante o ensino médio esse público deverá ser prioritariamente incluído em ações especificas de qualificação e aperfeiçoamento profissional, em programas de estágios e preparação para o empreendedorismo e para o mundo do trabalho por exemplo.

Acredita-se que para o cumprimento dos objetivos do Programa não basta apenas o repassa de benefícios, via PRM para as famílias, ou mesmo via os recursos e a poupança do PRMJ, mas sim por um conjunto de ações composto especialmente por oportunidades econômicas e sociais, objetivando a ampliação das oportunidades e capacidades para o público jovem em situação de extrema pobreza, só assim será possível romper com o ciclo intergeracional da pobreza.

\section{5.}

\section{Gestão de Oportunidades Econômicas e Sociais (GOES)}

Uma terceira estratégia do PRSM é a Gestão de Oportunidades Econômicas e Sociais, o GOES. Esta estratégia tem como objetivo aproximar as 
pessoas que vivem em condição de extrema pobreza com as oportunidades econômicas e sociais, reduzindo assim a assimetria e a distância de acesso a essas oportunidades.

"O GOES é uma estratégia muito importante para o Plano Rio Sem Miséria, visto que parte da premissa que não basta apenas a transferência de renda, mas é necessário um conjunto articulado de oportunidades econômicas e sociais, como próprio nome da estratégia já diz para que as famílias tenham condições de ampliar suas oportunidades e capacidades. E o nosso papel enquanto gestores e formuladores da estratégia é muito importante no sentido de aproximar as famílias das oportunidades". (Antonio Claret, Formulador e Gestor do PRSM)

O GOES possui algumas premissas, que podem sem considerados aspectos fundantes da sua atuação:

i) Intensivo em formação objetivando a inserção das famílias no mundo do trabalho;

ii) Coordenação entre as diversas esferas do Governo e atores da sociedade civil e da iniciativa privada;

iii) Especificidade do Estado como articulador e;

iv) Institucionalização da Gestão.

Os formuladores e gestores do PRSM acreditam que um dos aspectos mais importantes para a inserção das pessoas no mundo do trabalho no Estado do Rio de Janeiro seja a qualificação profissional, ou melhor, a ausência desta. De acordo com a Secretaria de Estado de Trabalho e Renda- SETRAB ${ }^{74}$, por meio das suas

\footnotetext{
${ }^{74}$ De acordo com o Diário Oficial do Rio de Janeiro, de 21.02.2014 .A Região Metropolitana do Rio fechou o mês de janeiro com taxa de desocupação de 3,6\%. O índice foi o menor para o mês de janeiro desde 2003, segundo levantamento divulgado ontem pelo IBGE (Instituto Brasileiro de Geografia e Estatística). A Pesquisa Mensal de Emprego revelou ainda que o Rio teve a segunda menor taxa de desocupação entre as seis regiões do país estudadas, superado apenas por Porto Alegre $(2,8 \%)$. A média nacional ficou em 4,8\%. O rendimento médio real da população ocupada na Região Metropolitana do Rio atingiu $\mathrm{R} \$ 2.148,80$ em janeiro. Esse total representa um crescimento de 7,3\% na comparação com o mesmo mês do ano passado. Todos os trabalhadores tiveram ganhos reais em relação a janeiro de 2013, com destaque para os empregados sem carteira assinada no setor privado, cuja expansão foi de 8,4\%. Em 12 meses, com exceção da área da construção civil, os trabalhadores de todos os grupamentos de atividade tiveram aumento no rendimento. Os destaques foram observados no comércio, nas atividades domésticas e os outros serviços, para os quais a expansão foi de $15,6 \%, 12,3 \%$ e 11,2\%, respectivamente. Em janeiro deste ano, havia na Região Metropolitana do Rio de Janeiro 10,5 milhões de pessoas em idade ativa. Essa população permaneceu estável na comparação mensal e cresceu 1,1\% frente ao mesmo mês de 2013. Dos trabalhadores com idade ativa, 52,1\% encontravam-se ocupados, 2,0\% desocupados e $46 \%$, não economicamente ativos.
} 
pesquisas, o Estado vem numa constante elevação de ocupação da mão de obra. Em janeiro de 2014, houve a menor taxa de desocupação dos últimos 11 anos, $3,6 \%$, ou seja, da população economicamente ativa - PEA total, apenas 3,6\% estava desocupada no período utilizado.

O Serviço Nacional de Tranportes - SEST-SENAT divulgou estudos demostrando a falta de mão de obra especializada do segmento: em setembro de 2014, havia mais de 11 mil vagas a serem preenchidas para motoristas de ônibus ( coletivos urbanos). De acordo com o responsável pela pesquisa no Estado, a condição se agrava mais ainda quando formos analisar ocupações mais especificas do setor como por exemplo motoristas de cargas perigosas, de resíduos químicos ou de resíduos médico hospitalares,

Ainda de acordo com a Federação da Indústria do Estado do Rio de Janeiro- FIRJAN, na pesquisa intitulada "O que falta ao trabalhador brasileiro", realizada no estado, 63\% das indústrias do Estado desejam ampliar os seus quadros para o ano de 2013. Desse total, 53\% não conseguiram, apontando como a principal dificuldade a falta de mão de obra qualificada para o atendimento das demandas. De acordo com a pesquisa (FIRJAN, 2012):

\footnotetext{
"Entre os principais problemas dos candidatos às vagas na indústria estão a falta de capacidade para assimilar conteúdo, raciocínio lógico, liderança e iniciativa. Dos entrevistados, $60,5 \%$ apontaram as quatro características, que ficaram à frente da própria capacitação profissional $(51 \%)$, experiência $(45,4 \%)$ ou nível de instrução escolar $(35,5 \%)$, como as maiores dificuldades para a contratação dos candidatos." (FIRJAN, 2012)
}

Observa-se a necessidade do investimento da capacitação profissional objetivando a inserção das famílias não apenas no mercado de trabalho, mas no mundo trabalho, visto que muitas pessoas, não terão condições de obter um emprego formal pelas próprias restrições de mercado, mas com formação terão condições de buscar outras alternativas como por exemplo a constituição de cooperativas de trabalho, o empreendedorismo individual, o negócio familiar, dentre outras opções.

Nesse sentido o GOES parte da premissa inicial de atuação que visa a capacitação profissional das famílias em situação de extrema pobreza, levando 
com consideração que trata-se de um público específico com necessidades de capacitação determinadas pela sua condição de ausência de acesso à educação, demonstrada pela baixa escolaridade destas populações e pela ausência de formação profissional das mesmas. Para enfrentar esta situação é necessária uma intervenção específica levando em consideração todos estes fatores, além é claro das situações cotidianas que colocam estas famílias em situação de vulnerabilidade e exclusão social.

Outra premissa importante da estratégia é a articulação entre os vários segmentos do poder públicos (governos Federal, Estadual e municipais), da iniciativa privada e da sociedade civil, para que seja constituída e soldada uma rede, objetivando o mapeamento das oportunidades e a aproximação das mesmas as famílias em situação de extrema vulnerabilidade.

\begin{abstract}
"Sabemos que no estado do Rio de Janeiro há uma gama muito grande de oportunidades de capacitação profissional. Como exemplo podemos citar a Faetec que oferta mais de 300 mil vagas por ano, a FIRJAN, o Sistema S, os Institutos Federais e vários outros, que proporcionam cursos gratuitos. O que ocorre é uma distância muito grande entre o público em situação de extrema pobreza que necessita de uma oportunidade de capacitação e estas oportunidades. Por isso a necessidade de que todos os atores que ofertam as oportunidades e o poder público com o apoio da sociedade civil possam formar uma rede sólida a fim que de estas oportunidades sejam aproximadas da população mais vulnerável e excluída socialmente, o nosso público do PRSM, para que de fato tenham acesso as mesmas". (Luis Gustavo, Superintendente de Gestão de Oportunidades)
\end{abstract}

No sentido do mapeamento e da aproximação das oportunidades para as famílias em situação de necessidade, o GOES prevê que o estado do Rio de Janeiro, por meio das suas Secretarias e segmentos da administração pública direta e indireta exercer o papel de articulador junto aos segmentos públicos, privados e a sociedade civil.

"O papel articulador do Estado é muito importante no sentido de mapear as oportunidades e disponibilizar as informações sobre as mesmas para outros parceiros, assim como aproximar as oportunidades no território para as famílias beneficiárias.” (Luis Gustavo, Superintendente de Gestão de Oportunidades) 
Como articulador central do processo, espera-se que a SEASDH desenvolva as seguintes atividades no que se refere ao GOES:

i) Organização das demandas;

ii) Interface das informações;

iii) Coordenação e indução de ofertas e;

iv) Monitoramento e avaliação.

Por outro lado, outro aspecto importante é a institucionalização das ações que permite com que as mesmas não fiquem na informalidade ou atreladas a aspectos pessoais, mas sejam compostas por um conjunto de fatores que vão desde o estabelecimento de fluxos, atribuições para os envolvidos, bem como a criação de instrumentos legais tais como acordos de cooperação técnicas e acordos de convênios, por exemplo.

\begin{abstract}
"Para que o GOES seja implementado, o Estado assume protagonismo na pactuação e articulação federativa no combate à miséria. Devido à proximidade $\mathrm{e}$ ao conhecimento das realidades locais, o Estado mune-se de capacidade técnica e operacional para, articulado com os municípios, conhecer as demandas e potenciais de famílias em situação de extrema pobreza aproximando-as das ofertas de cada território. Ou seja, a estratégia não consiste apenas em mapear a oportunidades existentes, mas em aproximar estas famílias e contribuir para as que as famílias possam acessar estas oportunidades." (Antonio Claret, Formulador e Gestor do PRSM)
\end{abstract}

O público alvo da estratégia do GOES são so beneficiários do Programa Renda Melhor e os jovens do PRMJ, ou seja, as famílias em situação de extrema pobreza, que na concretude significam aquelas que possuem menos acesso as oportunidades e menos acesso ás políticas públicas.

\title{
Objetivos e metodologia do GOES
}

Os objetivos estabelecidos pelo GOES consistem num processo integrado de ações que podem ser articulados em três conjuntos de ações conforme podemos podermos observar a seguir: 
i) Conhecer e sistematizar o perfil sócio econômico da população em situação de vulnerabilidade (extrema pobreza);

ii) Mapear e induzir as ofertas de políticas e de oportunidades econômicas;

iii) Reduzir a assimetria de oportunidades, aproximando os mundos da extrema pobreza do dinamismo econômico.

“O primeiro objetivo do GOES refere-se a sistematização das informações das famílias em situação de extrema pobreza. Estas informações foram obtidas por meio dos dados contidos no Cadastro Único, para a identificação do público alvo do PRM e o do Programa Renda Melhor Jovem. O segundo objetivo vai exigir uma ação da Coordenação Estadual no sentido de mapear das oportunidades do território oriundas de entre públicos e privados, Depois é necessário a construção de uma rede de articulação para que as oportunidades cheguem aos destinatários. É um caminho árduo e com muitos desafios, que precisam ser aos poucos vencidos." (Luis Gustavo, Superintendente de Gestão de Oportunidades)

Com relação a metodologia da estratégia, a mesma consiste no mapeamento das oportunidades econômicas e sociais, com a posterior informatização das informações. Concomitantemente é realizada a identificação das demandas das famílias. O passo final consiste na aproximação das demandas das famílias ás oportunidades. Abaixo, podemos observar a figura que ilustra a metodologia da estratégia. 


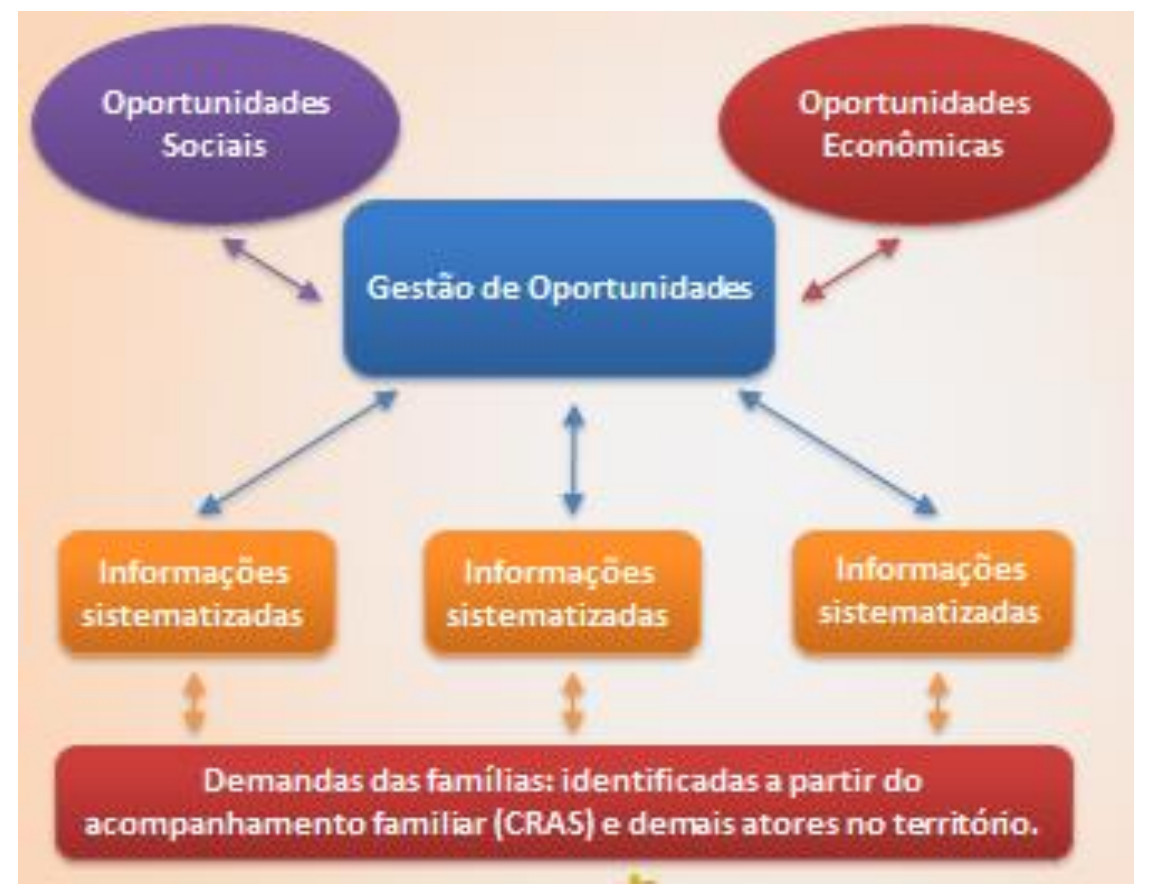

Figura 21- Metodologia do GOES. Fonte: SEASDH.

Para o mapeamento de demandas e potencialidades poderão ser realizados os seguintes procedimentos:

- $\quad$ Eventos $^{75}$ nos CRAS, CREAS e CREPOP;

- Reuniões com os técnicos da Assistência Social,

- Encontros e reuniões com as famílias e com as lideranças locais;

- Mobilização de atores do território e parceiros; e

- Apresentação e discussão do cardápio de ofertas sociais e econômicas ao município (sociedade civil e poder público).

De acordo com a estrutura pensada para o GOES os atores do território são um rol meramente exemplificativo, podendo ser inseridos novos atores sempre que necessários. Atualmente podem ser considerados como atores do GOES: o poder público (federal, estadual e municipal), a iniciativa privada, a sociedade civil e as lideranças formais e informais nos territórios. Já os parceiros são o poder público, a fundações públicas e privadas, a empresa, ONG's e organismos e parceiros internacionais.

\footnotetext{
${ }^{75}$ Quando estamos falando em eventos não queremos citar apenas reuniões, mas sim um conjunto articulado de ações tais como capacitações, encontros para discussões sobre a estratégias e demais que forem considerados necessários.
} 
A seguir faremos uma descrição das principais ações do GOES no Estado do Rio de Janeiro.

\section{Ações do GOES}

Apesar do mapeamento e da identificação das famílias em situação de extrema pobreza para o Renda Melhor e para o PRMJ, ou seja, apesar da identificação do público alvo do GOES, as estratégias desenvolvidas até o presente momento ainda não incipientes e carecem de maior investimento para que de fatos possam avançar.

Inicialmente buscou-se realizer a identificação de parceiros para a verificação das ofertas de oportunidades que estes poderiam oferecer às famílias e aos jovens. Dentre as parcerias realizadas podemos destacar que as mesmas foram iniciadas em 2011/2012, porém a grande maioria não foi renovada. A seguir passaremos a descrever as estratégias.

\section{1) Correios}

A parceria com os Correios consistiu na emissão do CPF para os jovens do Programa Renda Melhor Jovem gratuitamente. Os jovens identificados como beneficiários do Programa recebiam uma carta na escola comunicando a situação esta situção. Com esta carta dirigiam-se ás Agências dos Correios do Estado para emitir seu CPF gratuitamente.

Foi realizado um Convênio entre a SEASDH e os Correios para que a parceria pudesse ser estabelecida. Porém apesar de ser uma inicita muito válida, tendo em vista que oferece o acesso a documentação necessária para os jovens efetuarem a abertura da conta corrente no Banco do Brasil para o recebimento do beneficio, a parceria está inativa.

\section{2) Sinduscon}

O Sinduscon - RIO, é o Sindicato da Indústria da Construção Civil no Estado do Rio de Janeiro, se configurando como uma entidade pioneira da classe empresarial da Indústria da Construção brasileira, fundada em 1919 
É o representante legal de todas as empresas da construção civil do Estado do Rio de Janeiro, com mais de 2.000 empresas filiadas e mais de 200 empresas associadas. Apresenta-se como o interlocutor oficial das empresas da construção civil do Estado para efetuar negociações com o Sindicado dos Trabalhadores da Construção Civil do Município do Rio de Janeiro e dos demais municípios do Estado.

Além disso possui amplo canal de discussão com entidades empresariais de nível estadual e nacional como a FIRJAN, a Confederação Nacional da IndústriaCNI e a Câmara Brasileira da Indústria da Construção - CBIC. Outras parcerias e interlocuções importantes são realizadas com instituições em âmbito municipal estadual e federal. Uma delas é a parceria com GOES.

A parceria com o GOES consistiu no sentido de oferecer cursos de qualificação profissional para a área da construção civil, de maneira gratuita para os trabalhadores já inseridos no trabalho na área da construção civil, bem como para aqueles que estão iniciando as atividades na área. Também foi estabelecida a parceria no sentido do encaminhamento para o mercado do trabalho tanto do público capacitados no cursos gratuitos, como daqueles que já possuem capacitação para serem inseridos no mercado de trabalho na área da construção civil.

Outra ação importante do SINDUSCON que foi estendido ao público do GOES é o ALFABETIZAR É CONSTRUIR, um programa pioneiro de alfabetização de trabalhadores em canteiros de obras, agraciado pelo Ministério da Educação com o prêmio "Educação para a Qualidade do Trabalho", em 1997. Mais de 12.000 trabalhadores atendidos em mais de vinte anos.

Para a execução desta estratégia foi formalizado um Convênio entre a SEASDH e o Sinduscon, para que ocorresse a oferta prioritária de cursos e vagas no mercado de trabalho. Ocorre que o convênio perdurou apenas por um ano, não sendo renovado, bem como estabelecido um fluxo para acompanhamento dos beneficiários para o encaminhamento aos programas de capacitação profissional e inserção no mercado de trabalho e nem para posterior acompanhamento após estas ações. 


\section{3) Seconci}

O Serviço Social da Indústria da Construção do Rio de Janeiro SECONCI é uma associação civil, sem fins lucrativos, financiada e gerenciada pelos empresários da construção do Rio de Janeiro. Através da contribuição mensal de $1 \%$ sobre a folha de pagamentos das mais de 1000 empresas contribuintes, o SECONCI oferece uma ampla assistência social além de atividades educativas, de promoção da saúde e prevenção de doenças aos trabalhadores da construção civil do estado.

Concebido e gerenciado sob a ótica empresarial, o Seconci é uma entidade que coloca à disposição das empresas e de seus trabalhadores, mais de 300.000 atendimentos anuais nas áreas saúde, assistência social e de capacitação profissional.

A estratégia pactuada com o GOES por meio de convênio foi a oferta de capacitação profissional para os trabalhadores já inseridos na área da construção civil. A exemplo da parceria com o Sinduscon, a parceria com o Seconci foi realizada por um ano e não foi renovada, bem como não foi estabelecido um fluxo para acompanhamento dos beneficiários para o encaminhamento aos programas de capacitação profissional e e nem para posterior acompanhamento após estas ações.

\section{4) Investe Rio}

O Investe Rio é uma das estratégias da AGE- RIO, a Agência Estadual de Fomento, criada pelo Decreto Estadual $n^{\circ} 32.376$, de 12/12/2002. Ela é uma sociedade de economia mista, vinculada à Secretaria Estadual de Desenvolvimento Econômico, Energia, Indústria e Serviços do estado do Rio de Janeiro (Sedeis). Seu objetivo principal é estimular o desenvolvimento econômico do estado do Rio de Janeiro, sempre mantendo a responsabilidade socioambiental e as boas práticas de governança, com a oferta de excelência em serviços.

Por meio de recursos próprios; de repasses de linhas de crédito do Banco Nacional de Desenvolvimento Econômico e Social (BNDES), da Caixa Econômica Federal (FGTS) e da Financiadora de Estudos e Projetos - Finep (Inovacred); ou de fundos de fomento, a AGE-RIO investe em projetos de todos os portes, da micro à grande empresa, esperando como resultado a geração de 
emprego e renda no Estado e a constante melhoria das condições de vida dos cidadãos.

Por destina-se também a micro empresas e a empreendedores individuais foi realizada uma parceria entre a SEASDH e a INVESTE RIO para a oferta prioritária de micro crédito individual para os beneficiários do Plano Rio Sem Miséria, por meio da assinatura de um convênio.

Da mesma maneira dos anteriores, esta parceria não foi renovada após uma no de execução, bem como não foi elaborado um fuxo de encaminhamento dos beneficiários e realizado acompanhamento daqueles que receberam o crédito. Não há informações do quantitativo de beneficiários do PRSM que foram beneficiados com a presente estratégia.

\section{5) L'OREAL}

O Instituto L'Oréal Professionnel teve a sua primeira unidade inaugurada em 2010, no Rio de Janeiro, que como objetivos preparar os profissionais para o mercado da beleza. Atualmente, existem sete centros de ensino no Brasil, (dois no Rio de Janeiro), e um na África do Sul.

Com relação a parceria estabelecida com o GOES foi a oferta de cursos gratuitos na área da beleza: cabelereiro, penteados, maquiagem, etc..por meio da assinatura de um Convênio, que após um ano não foi renovado.

Não é possível identificar o número de alunos capacitados pela L'oreal que são beneficiários do PRSM, nem foi elaborado fluxo de indicação de alunos e estabelecido um acompanhamento para os mesmos.

\section{6) MetroRio}

O MetrôRio é a empresa responsável pelo metrô no estado do Rio de Janeiro. E constantemente tem intensificado as suas ações de relacionamento com as comunidades, apoiando diversos projetos sociais, culturais, de inclusão ou de geração de renda. Com isso, a Concessionária, em apenas um ano, subiu de 6,9 para a nota 7,9 na Escala Ethos.

Dentre os principais projetos, estão o Jovem Aprendiz (absorção de mão de obra), Gastronomia Solidária (aulas de culinária com alocação de alunos no mercado hoteleiro), Defensores da Terra (reaproveitamento de lixo para a 
confecção de brinquedos), Rede Comunitária (orientação a líderes comunitários para captação de patrocínio para projetos) e o Quiosque Solidário (para venda de artesanato nas estações).

Em consonância com as diretrizes de responsabilidade social, o MetrôRio assinou contrato de Cooperação Técnica para a oferta de oportunidades econômicas e sociais do PRMS. Em 2014 o Convênio foi renovado e abrange o município do Rio de Janeiro.

No decorrer da vigência do Acordo de Cooperação o MetrôRio encaminhou as informações acerca de seus projetos, porém as mesmas não foram repassadas para as Gestões Municipais e para as famílias beneficiárias, visto que não há fluxo estabelecido para o repasse de informações e para o acompanhamento dos beneficiários.

\section{7) FAETEC}

Responsável pela implementação da política de Educação Profissional e Tecnológica pública e gratuita no Estado do Rio de Janeiro, a Fundação de Apoio à Escola Técnica (Faetec), vinculada à Secretaria de Estado de Ciência e Tecnologia, deu seus primeiros passos em 10 de junho de 1997. Atualmente, a Rede atende cerca de 300 mil alunos por ano em mais de 130 unidades de ensino, que somam a oferta no Ensino Técnico de Nível Médio, na Formação Inicial e Continuada / Qualificação Profissional e na Educação Superior.

Com ampla oferta de Educação Profissional e Tecnológica pública e gratuita de qualidade, a Faetec está em todas as regiões do Estado do Rio de Janeiro, apostando no potencial econômico dos municípios fluminenses. Ao todo, 51 cidades contam com a presença da Fundação através de oportunidades em diversos segmentos de ensino.

Algumas das unidades são: Escolas Técnicas Estaduais (ETEs), Centros de Educação Tecnológica e Profissionalizante (Ceteps), Centros Vocacionais Tecnológicos (CVTs), Escolas de Artes Técnicas (EATs), Faculdades de Educação Tecnológica do Estado do Rio de Janeiro (Faeterjs) e Centros de Referência em Formação de Profissionais da Educação (Iserj e Isepam).

O ensino na Rede é desenvolvido com base nos seguintes eixos tecnológicos: Ambiente e Saúde; Controle e Processos Industriais; 
Desenvolvimento Educacional e Social; Gestão e Negócios; Informação e Comunicação; Infraestrutura; Produção Alimentícia; Produção Cultural e Design; Produção Industrial; Recursos Naturais; Segurança; Turismo, Hospitalidade e Lazer.

Em maio/2013 foi assinado o Convênio 065/2013 entre a FAETEC e SEASDH, com o objetivo da oferta de cursos de capacitação profissional no âmbito do Plano Rio Sem Miséria. O convênio prevê a oferta de 1.252 vagas de capacitação profissional, nas diversas áreas, de acordo com a disponibilidade da oferta da grande da Fundação, nos municípios de Duque de Caixas, São Gonçalo, Mesquita e Nilópolis.

No ano de 2014, após a reunião realizada em 08/05/2014, na qual estivemos presentes, entre SEASDH, FAETEC e representantes dos municípios de Duque de Caxias, São Gonçalo, Nilópolis e Mesquita foi apresentada a proposta do convênio, bem como foram definidas algumas estratégias para a execução do Convênio, bem como apresentada a oferta de cursos e vagas para os representantes das Gestões Municipais.

De acordo com as informações enviadas pela Diretoria de Formação Continuada - DIF, da FAETEC, com a relação ao Convênio, as informações com relação a Unidades, cursos, vagas ofertadas e vagas preenchidas podemos visualizar na tabela abaixo. 
Tabela 2- Resultado do convênio FAETEC

\begin{tabular}{|c|c|c|c|}
\hline UNIDADE & CURSO & $\begin{array}{c}\text { VAGAS } \\
\text { OFERTADAS }\end{array}$ & $\begin{array}{c}\text { VAGAS } \\
\text { PREENCHIDAS }\end{array}$ \\
\hline \multirow[t]{3}{*}{ CVT SÃO GONÇALO } & SALGADEIRO & $\begin{array}{c}\text { CONFORME } \\
\text { PROCURA }\end{array}$ & SEM PROCURA \\
\hline & $\begin{array}{c}\text { INGLÊS PARA SERVIÇOS } \\
\text { TURÍSTICOS } \\
\end{array}$ & $\begin{array}{l}\text { CONFORME } \\
\text { PROCURA }\end{array}$ & SEM PROCURA \\
\hline & $\begin{array}{l}\text { PINTURA DE PEQUENAS } \\
\text { EMBARCAÇÕES }\end{array}$ & $\begin{array}{l}\text { CONFORME } \\
\text { PROCURA }\end{array}$ & 1 \\
\hline UNIDADE & CURSO & $\begin{array}{c}\text { VAGAS } \\
\text { OFERTADAS }\end{array}$ & $\begin{array}{c}\text { VAGAS } \\
\text { PREENCHIDAS }\end{array}$ \\
\hline \multirow[t]{2}{*}{ CVT CORREIOS } & $\begin{array}{c}\text { OPERADOR DE } \\
\text { TELEMARKETING }\end{array}$ & $\begin{array}{l}\text { CONFORME } \\
\text { PROCURA }\end{array}$ & SEM PROCURA \\
\hline & MANICURE E PEDICURE & $\begin{array}{l}\text { CONFORME } \\
\text { PROCURA }\end{array}$ & SEM PROCURA \\
\hline UNIDADE & CURSO & $\begin{array}{c}\text { VAGAS } \\
\text { OFERTADAS }\end{array}$ & $\begin{array}{c}\text { VAGAS } \\
\text { PREENCHIDAS }\end{array}$ \\
\hline \multirow{3}{*}{ CVT NILÓPOLIS } & COSTUREIRO & $\begin{array}{l}\text { CONFORME } \\
\text { PROCURA }\end{array}$ & SEM PROCURA \\
\hline & $\begin{array}{c}\text { INGLÊS PARA SERVIÇOS } \\
\text { TURÍSTICOS } \\
\end{array}$ & $\begin{array}{l}\text { CONFORME } \\
\text { PROCURA }\end{array}$ & SEM PROCURA \\
\hline & $\begin{array}{c}\text { CAMAREIRA EM MEIOS DE } \\
\text { HOSPEDAGEM }\end{array}$ & $\begin{array}{l}\text { CONFORME } \\
\text { PROCURA }\end{array}$ & SEM PROCURA \\
\hline UNIDADE & CURSO & $\begin{array}{c}\text { VAGAS } \\
\text { OFERTADAS } \\
\end{array}$ & $\begin{array}{c}\text { VAGAS } \\
\text { PREENCHIDAS }\end{array}$ \\
\hline \multirow[t]{2}{*}{ CVT CORREIOS } & $\begin{array}{c}\text { OPERADOR DE } \\
\text { TELEMARKETING }\end{array}$ & $\begin{array}{l}\text { CONFORME } \\
\text { PROCURA }\end{array}$ & SEM PROCURA \\
\hline & MANICURE E PEDICURE & $\begin{array}{l}\text { CONFORME } \\
\text { PROCURA }\end{array}$ & SEM PROCURA \\
\hline
\end{tabular}

Fonte: FAETEC.

Com relação ao Convênio entre a SEASDH e a Faetec, avaliamos que:

i) A parceria entre FAETEC e SEASDH é de suma importância para as ações do Plano Rio Sem Miséria no que se refere a oferta de capacitação profissional no Estado do Rio de Janeiro bem sua capilaridade e pelo volume de cursos e vagas ofertadas ( mais de 300 mil ofertas anuais);

ii) Há necessidade da ampliação do Convênio para outros municípios especialmente aqueles que não conseguem pactuar ou obter a homologação e vagas;

iii) É pertinente a laboração de estratégias para acompanhamento do Convênio de maneira sistemática; 
iv) É extremamente importante a elaboração de estratégia comunicacional entre SEASDH, FAETEC e Gestões Municipais para acompanhamento e avaliação do Convênio.

Portanto, a parceria carece de um processo de elaboração de fluxo para um acompanhamento e monitoramento mais eficiente das ações.

\section{8) Coletivo Coca Cola}

O projeto 'Coletivo' da Coca-Cola oferece curso de preparação para o mercado de varejo a jovens de 15 a 25 anos. Durante o curso, os participantes têm aulas sobre empregabilidade, mercado de varejo, relacionamento, palestras de profissionais de grandes empresas, simulações de dinâmicas e entrevistas. No fim do projeto, a Coca-Cola encaminha os jovens para processos seletivos de grandes redes de varejo e para a própria Coca-Cola. O curso forma cerca de 120 pessoas, de dois em dois meses, em cada unidade do Coletivo. Os cursos são realizados em salas montadas em projetos sociais selecionados pela Coca-Cola em todo o Brasil.

Uma das estratégias do GOES consiste na assinatura de um Termo de Cooperação Técnica para a capacitação de quase 2 mil jovens nos municípios de Japeri, na Baixada Fluminense, e São Gonçalo, na Região Metropolitana. Com a parceria, os beneficiários do programa Renda Melhor Jovem terão prioridade de vaga nos cursos de capacitação oferecidos pelo projeto Coletivo, da Coca-Cola.

Inicialmente serão oferecidas 485 vagas aos beneficiários do Renda Melhor Jovem de Japeri, e 1.508 vagas aos beneficiários de São Gonçalo.O Coletivo Coca é executado em parceria entre a SEASDH, a SEEDUC e a Coca Cola , num modelo de gestão compartilhada.

\section{9) CIEE}

Uma das estratégias mais proeminentes do GOES é a parceria com Centro de Integração Empresa-Escola (CIEE), que levou o Programa de Iniciação do Trabalho-PIT para municípios atendidos pelo Rio Sem Miséria, com o objetivo de auxiliar estudantes que estão incluídos no Renda Melhor Jovem. O Acordo de Cooperação foi assinado em 2012 e renovado no ano de 2014 
Em Japeri, três turmas reuniram cerca de 70 alunos. Já em Duque de Caxias, também na Baixada Fluminense, cerca de 140 estudantes participaram do curso em quatro turmas. Nas aulas, que envolvem ensinamentos teóricos e dinâmicas comportamentais, os jovens receberam orientação pessoal e profissional voltada para o sucesso no mercado de trabalho. Após concluírem o curso, todos os alunos são incluídos no banco de dados do CIEE e encaminhados para processos seletivos.

Cada ciclo de aulas tem a duração de dois meses e, ao final, os alunos têm a oportunidade de aplicar os conhecimentos, elaborando planos de negócios para comércios locais. $\mathrm{O}$ encaminhamento para o mercado de trabalho é feito por meio da Coca-Cola Brasil e seus fabricantes, contando também com clientes e fornecedores - como grandes redes de lanchonetes.

O acompanhamento desta estratégia é realizado pelo CIEE e pela SEEDUC que encaminham os relatórios de execução anuais para a SEASDH.

\section{0) Universidade Federal do Rio de Janeiro}

No decorrer do ano de 2013 e 2014, a Escola de Serviço Social da UFRJ, realizou a parceria 01/2013 - PIBEX-UFRJ, denominada Assistência Social e Inclusão Produtiva: Brasil Sem Miséria e Rio Sem Miséria coordenado pela professora doutora Fatima Valeria Ferreira de Souza.

Como produtos do Projeto no que se refere ao PRONATEC, foram originados:

- Caderno de Textos: "Assistência Social e Inclusão Produtiva", organizado pela professora doutora Fatima Valeria Ferreira de Souza, com a publicação do Guia de Orientação sobre o PRONATEC/BSM elaborado pela equipe do PRONATEC; e

- Realização da Oficina de Inclusão Produtiva, da qual tive oportunidade de participar.

\section{1) Gratuidade do Sistema $S$}

Firmado um protocolo, em 2008, entre o Governo Federal e o Sistema S, ratificado pelo Decreto $n^{\circ}$ 6.633/2008 (SENAC) e Decreto $n^{\circ}$ 6635/2008 (SENAI), 
para oferecer ações educacionais com custo zero à população brasileira de baixa renda.

As entidades estabeleceram um programa de comprometimento de gratuidade que previu:

- aplicação de dois terços das receitas líquidas de Senai e Senac até 2014 na oferta de vagas gratuitas de cursos de educação profissional técnica e de qualificação profissional para estudantes de baixa renda ou trabalhadores - empregados ou desempregados;

- Sesi e Sesc destinarão um terço de seus recursos à educação;

- Aumento da carga horária dos cursos de Formação Inicial e Continuada, que passaram a ter no mínimo 160 horas.

No Estado do Rio de Janeiro, em função de vários municípios não terem obtido a homologação de vagas pelo MEC para o PRONATE/BSM, algumas Unidades Ofertantes estão realizando parcerias para que os cursos na Gratuidade.

Não foi possível obter informações junto ao Sistema $S$ no que se refere ao número de alunos capacitados por meio da gratuidade, bem como a Coordenação do GOES não teve condição de nos repassar as informações.

\section{2) Parcerias em discussão}

As seguintes parcerias estão em discussão e deverão compor a estratégia do GOES:

- WALMART: capacitação e vagas de emprego;

- CONTAX: capacitação e vagas de aprendiz e emprego;

- Banco do Brasil:oferta de microcrédito preferencial;

- Proderj: desenvolvimento e manutenção de um site.

O Pronatec- BSM como uma das estratégias do GOES

O Programa Nacional de Acesso ao Ensino Técnico e ao Emprego Brasil Sem Miséria (Pronatec/BSM) é uma das principais ações de inclusão produtiva do Plano Brasil sem Miséria. É também a principal estratégia do GOES no estado do Rio de Janeiro. 
Foi criado pela Lei $n^{\circ}$ 12.513, em 2011 e é um conjunto de ações que visam a expandir, interiorizar e democratizar a oferta de cursos de Educação Profissional e Tecnológica para a população brasileira, melhorando as condições de inserção no mundo do trabalho. É coordenado pelo Ministério da Educação (MEC) e custeado com recursos do Fundo Nacional de Desenvolvimento da Educação (FNDE). A gestão e a execução do Pronatec/BSM são realizadas de maneira compartilhada entre a União, os Estados, os Municípios e as Unidades Ofertantes.

O Pronatec prevê a oferta gratuita de qualificação profissional para pessoas inscritas ou em processo de inclusão no Cadastro Único para Programas Sociais do Governo Federal (Cadastro Único), na modalidade intitulada Bolsa-Formação Trabalhador, sob a forma de cursos de Formação Inicial e Continuada (FIC). Os cursos de formação inicial e continuada são voltados para a inserção no mercado de trabalho, com duração mínima de 160 horas, sendo custeados pelo Governo Federal (MEC) junto às Unidades Ofertantes.

Com relação aos beneficiários da modalidade de Pronatec/BSM estes compõem-se prioritariamente por:

- Estudantes do ensino médio da rede pública, inclusive da educação de jovens e adultos;

- Trabalhadores;

- Beneficiários titulares e dependentes dos programas federais de transferência de renda (ex.: beneficiários do Programa Bolsa Família);

- Estudantes que tenham cursado o ensino médio completo em escolas da rede pública ou em instituições privadas na condição de bolsista integral;

- Pessoas com deficiência; e

- Jovens em cumprimento de medidas socioeducativas.

As Unidades Ofertantes do Pronatec/BSM são responsáveis pela oferta de qualificação profissional por meio da oferta de cursos de vagas. No Estado do Rio de Janeiro são as seguintes a Unidades Ofertantes do Pronatec/BSM: 
- Rede Federal de Educação Profissional e Tecnológica: IFF, IFRJ, Colégio Técnico da Universidade Federal do Rio de Janeiro e Colégio Pedro II;

- Serviços Nacionais de Aprendizagem (Sistema S): SEST/SENAT, SENAR, SENAC SENAI;

- Redes Estaduais e Municipais de Educação Profissional e Tecnológica: FAETEC; e

- Redes Privadas habilitadas: ainda em processo de habilitação junto ao MEC.

A adesão dos municípios ao PRONATEC/BSM é o primeiro passo para que as Gestões Municipais possam ofertar pactuar e ofertar cursos. O processo é efetuado eletronicamente por meio do acesso ao link www.brasilsemmiseria.gov.br, com CPF e a senha de acesso do Gestor Municipal de Assistência Social ao CADSUAS.

No Estado do Rio de Janeiro, em janeiro de 2014, $100 \%$ dos municípios haviam aderido ao Pronatec/ BSM sendo o Estado um dos primeiros do Brasil a conseguir atingir esta meta (Fonte: e-mail MDS).

Na tabela abaixo, podemos observar a evolução da adesão dos municípios ao Pronatec/BSM

Tabela 3- Histórico da adesão dos municípios do PRONATEC/BS

\begin{tabular}{|c|c|c|}
\hline Ano & $\begin{array}{c}\text { Total Municípios } \\
\text { com adesão }\end{array}$ & \% Adesão \\
\hline 2012 & 36 & $39 \%$ \\
\hline 2013 & 54 & $59 \%$ \\
\hline 2014 & 2 & $2 \%$ \\
\hline TOTAL & $\mathbf{9 2}$ & $\mathbf{1 0 0 \%}$ \\
\hline
\end{tabular}

Fonte: MDS. Elaboração da autora, 2014.

Podemos constatar que no ano de 2012 apenas 36 municípios do Estado haviam aderido ao Programa, representando 39\% do total de municípios. Em 2013, após a ampliação das estratégias já elencadas, bem como a aproximação e a criação de canal comunicacional mais estreito com as Gestões Municipais 
possibilitou a adesão de 54 municípios (59\% do total). Ao final de 2013, 90 municípios ( $98 \%$ do total) haviam aderido ao Pronatec/BSM.

Em janeiro 2014, com estratégias mais específicas ${ }^{76}$ com os municípios de Macuco e Conceição de Macabu, que eram os únicos municípios que ainda não haviam efetuado a adesão, os referidos municípios que haviam iniciado o processo eletrônico em 2013, enviaram a documentação e concluíram o processo de adesão, de acordo com as regras estabelecidas.

Abaixo podemos visualizar o mapa do Estado com as informações sobre a adesão dos municípios:

76 Contato telefônico com os Gestores Municipais de Assistência Social e com os prefeitos municipais, destacando a importância da adesão ao PRONATEC e os benefícios que a mesma traria para a Gestão Municipal e para os cidadãos. 


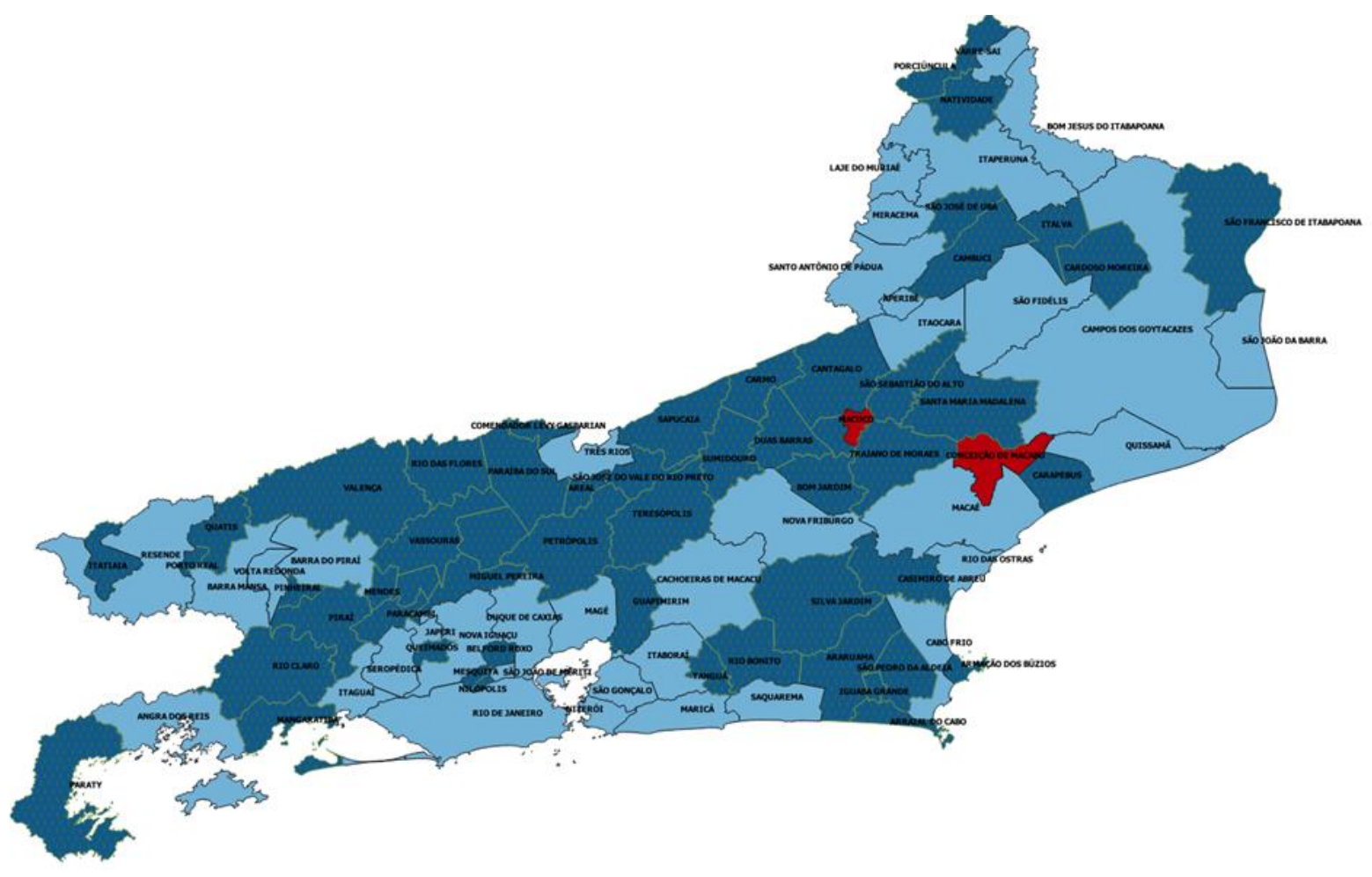

\section{LEGENDA}

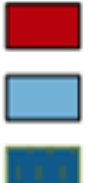

Adesão em 2014

Adesão em 2013

Adesão em 2012

Figura 22- Mapa com o ano da adesão dos municípios fluminenses ao PRONATEC/BSM. Fonte: MDS. Elaboração da autora, 2014.

Todos os municípios podem aderir ao Pronatec/BSM, porém a adesão não implica na oferta automática de cursos e vagas. Ou seja, o Programa somente se efetivará no município mediante a pactuação de cursos e vagas entre os municípios e as Unidades Ofertantes.

As após a negociação das vagas o MEC efetua a homologação das mesmas. No Estado do Rio de Janeiro, das 86.056 vagas solicitadas, apenas 20.889 (vinte mil oitocentos e oitenta e nove) constavam no SISTEC como aprovadas, isto é, como homologadas para serem ofertados pelos municípios.

Após a homologação das vagas, ocorre a pré-matrícula, onde os gestores municipais do PRONATEC/BSM registram no SISTEC/MEC os dados dos interessados nos cursos de qualificação, preenchendo as vagas dos cursos 
negociados. É recomendável que cada turma receba o número de pré-matrículas até duas vezes superiores ao número de vagas.

Após a pré-matrícula vem a fase matrículas, que é o momento em que o beneficiário se dirige a uma Unidade Ofertante para confirmar sua inscrição no curso desejado. Deve ser realizado imediatamente após a realização da prématrícula, para que o candidato garanta a sua vaga na turma, pois a matrícula é realizada na ordem de chegada à unidade ofertante.

Os resultados do Estado do Rio de Janeiro com relação ao Pronatec-BSM para os anos de 2013 e 2014 podem ser visualizados na figura abaixo.
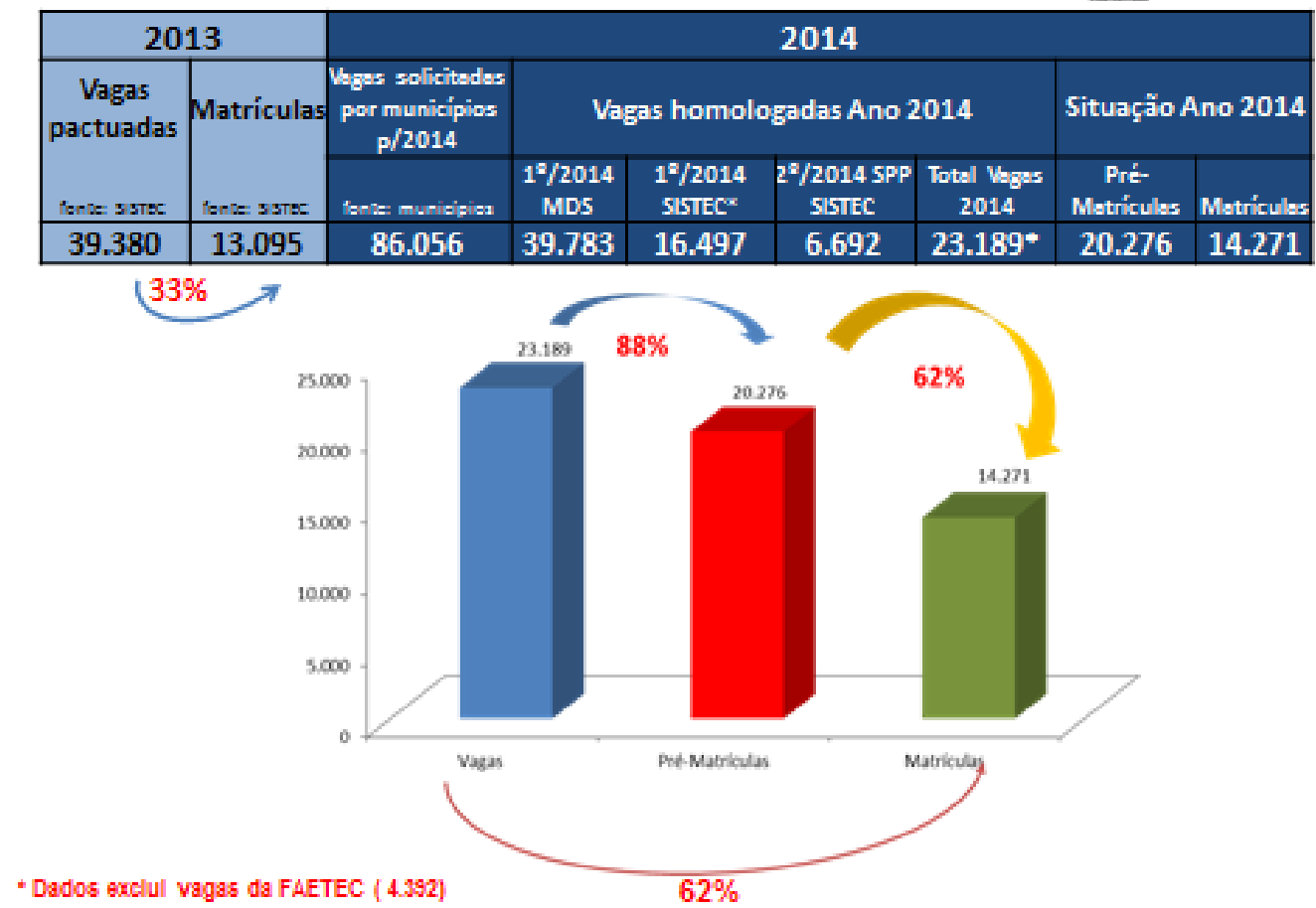

Figura 23- Quadro com a execução do Pronatec/BSM no Estado do RJ. Fonte: SISTEC, elaboração da autora.

Podemos observar pelo desenho do quadro acima o estado do Rio de Janeiro apresenta um quadro de baixa execução do Pronatec. Do total de vagas disponibilizadas em 2013, apenas $13 \%$ foram executadas. Para o ano de 2014, os números tiveram considerável aumento, porém ainda estão abaixo do desejável, visto que de acordo com consulta ao SISTEC, a maioria dos estados brasileiros tem execução superior a $100 \%$. 
Após a pesquisa observamos que o Pronatec-BSM é uma das estratégias de integração entre o PBSM e o Plano Rio Sem Miséria que precisa ser aperfeiçoada no Estado do Rio de Janeiro.

\section{6.}

\section{Fortalecimento do Sistema Único Assistência Social e Acompanhamento Familiar}

A quarta estratégia do Plano Rio Sem Miséria refere-se a um esforço para a ampliação da rede sócio assistencial objetivando com que o Plano tenha condições de ser efetuado pelas Gestões Municipais.

Com a adesão do município ao Plano Rio Sem Miséria, estes também assumem o protagonismo na execução das ações por meio do acompanhamento familiar e da busca ativa para a inclusão das famílias no Cadastro Único. Nesse sentido, o fortalecimento da rede socioassisntencial do SUAS é vital para o fortalecimento, a execução e o sucesso do Plano.

A seguir faremos uma descrição das principais ações que compõem esta estratégia do PRSM.

\subsection{1. Fortalecimento do SUAS}

A política de assistência social não tem seu campo de atuação restrito à questão da pobreza, mas busca afiançar direitos sociais e a inclusão social. Assim sendo, pobreza não é concebida apenas como sinônimo de insuficiência de renda, mas como uma situação complexa e multidimensional que exige a oferta de serviços que possam contribuir para o apoio às famílias, na ampliação da sua capacidade protetiva, objetivando a superação das situações de vulnerabilidades sociais e riscos sociais e pessoais.

Porém, de acordo com Sposati (2009, p.33): 
"Não são todas as necessidades humanas de proteção social que estão para resolutividade da assistência social, como também não são todas as necessidades de proteção social dos pobres que aqui são consideradas como específicas da assistência social. Elas são comuns a várias políticas."

A política de assistência social possui suas especificidades estabelecidas na Lei Orgânica da Assistência Social, a Loas. Dentre estas podemos citar como basilar a proteção social, que visa a garantia à vida, a redução de danos e a prevenção de incidência de riscos. A Política Nacional de Assistência Social (PNAS) tem como princípios a centralidade na família, a proteção proativa e a integração à seguridade social e ás políticas sociais e econômicas.

Considerando a Norma Operacional Básica do SUAS (NOB/SUAS), a proteção social da assistência social abrange um "conjunto de ações, cuidados, atenções, benefícios e auxílios ofertados pelo SUAS para a redução e a prevenção do impacto das vicissitudes sociais e naturais ao ciclo da vida, à dignidade humana e à família". Essas ofertas estão organizadas no SUAS em tipos de proteção - proteção social básica e proteção social especial - e são providas por meio de serviço, benefícios e programas, projetos, vigilância sócio assistencial e defesa de direitos.

As seguranças sócio assistenciais afiançadas pela política de assistência social, que orientam as ofertas disponibilizadas pelo SUAS são: segurança de sobrevivência ou de rendimentos e autonomia; segurança de convívio ou vivência familiar e segurança de acolhida.

Os públicos e as situações atendidas pela Assistência Social, de acordo com Sposati (2009) se colocam no campo da proteção relacional, atuando na prevenção e superação das situações de isolamentos, subordinação e exclusão social. A definição das funções da assistência social, das seguranças socioassistenciais afiançadas e das situações atendidas que demarcam a atenção não somente para a segurança monetária de renda, mas para o atendimento das necessidades básicas de sobrevivência: se ocupa em ofertar atenção a situações de vulnerabilidades sociais e de riscos pessoais e sociais.

A atuação da equipe de Assistência Social, bem como a construção de ações Inter setoriais com a saúde e a educação são fundamentais em função do conhecimento do território, bem como das condições da realização da interlocução 
direta e do acompanhamento sistemático com as famílias em situação de extrema pobreza.

O papel do Estado nesta estratégia consiste em oferecer aos municípios assessoramento técnico, capacitação contínua e cofinanciamento (como por exemplo, a expansão de CRAS e CREAS) e o fortalecimento da ação técnica efetuada pelos municípios, objetivando o fortalecimento da potencialização para o atendimento das demandas ás famílias no processo de alcance das seguranças sociais.

No Estado do Rio de Janeiro, a responsabilidade da política de Assistência Social é da Secretaria Estadual de Assistência Social e Direitos Humanos SEASDH. De acordo com o Censo Suas 2012, os 92 municípios aderiram a SUAS e assim como o Estado, assinaram o Pacto de Aprimoramento da Gestão em 2012. Censo revela ainda que há no estado mais de 15 mil trabalhadores do SUAS (entre nível fundamental, médio e superior), 448 Centros de Referência em Assistência Social - CRAS, 105 Centros Especializados em Assistência Social - CREAS e 17 Centros de Atendimento à População de Rua - Centro POP.

A CIB tem desempenhado relevante papel na condução da política no Estado, ao ser o local dos grandes debates, decisões e pactuações que são realizadas no Estado, com a participação significativa dos municípios nas reuniões mensais

\subsection{2.}

\section{Acompanhamento Familiar}

Embora a importância dada à discussão dada a centralidade familiar seja recente, a preocupação com o tema é histórica e o trabalho social com famílias não é algo novo na Assistência Social. Contudo, por muitos anos a atenção à família esteve fortemente associada a práticas disciplinadoras marcadas por uma trajetória de fragmentação e individualização das questões em um dos membros, com prevalência de ações voltadas à adequação do modo de vida a um modelo tradicional. 
Objetivando atender a necessidade da demanda de elaboração de um modelo para o acompanhamento familiar previsto no Plano Rio Sem Miséria, a Subsecretaria de Assistência Social e Descentralização da Gestão (SSASDG) concebeu uma metodologia para ser implantada no pelo SUAS/RJ. De acordo com o Manual de Acompanhamento Familiar do Estado do Rio de Janeiro ( 2013, p.7):

"O Acompanhamento Familiar no âmbito do SUAS/RJ tem como diretriz a abordagem metodológica dialógico-reflexiva, referenciada teoricamente pela Teoria Social Crítica, sob a orientação de Paulo Freire. A adoção desta abordagem metodológica implica, fundamentalmente, em privilegiar, no processo de acompanhamento familiar, atividades que possibilitem a reflexão sobre a realidade, o cotidiano social e a garantia de uma condução participativa e horizontalizada de todo processo".

O Acompanhamento Familiar no âmbito do SUAS é definido como o conjunto de intervenções desenvolvidas em serviços continuados, com objetivos estabelecidos que possibilitam à família acesso a um espaço onde possa refletir sobre sua realidade, construir novos projetos de vida e transformar suas relações, sejam elas familiares ou comunitárias. O trabalho de acompanhamento das famílias deve ser orientado pelas diretrizes concernentes aos programas, quais sejam, de acordo com as orientações do SUAS:

- Trabalhar, em caráter de prevenção das situações de risco, com todas as famílias do território de abrangência do CRAS e, em especial, com aquelas em situação de descumprimento das condicionalidades com vistas à superação de dificuldades e efetiva inclusão nos serviços de saúde, educação e assistência social;

- Respeitar cada família, incentivando a sua participação no trabalho socioeducativo, de acordo com as referências culturais, seus ciclos de vida, seu ritmo de desenvolvimento e seus projetos e incentivando seu protagonismo;

- Promover, por meio do trabalho socioeducativo, a articulação entre a informação, a reflexão e o desenvolvimento de habilidades e capacidades das famílias, buscando dar expressão e sustentabilidade a essas mudanças nas práticas cotidianas; 
- Propiciar a transversalidade dos conteúdos de gênero e étnicoculturais e o desenvolvimento de ações intersetoriais, fortalecendo a interlocução e a ação conjunta, nos territórios, da assistência social, da saúde, da educação e de outras áreas envolvidas no desenvolvimento social, potencializando o acolhimento da família e seus membros nas instituições, programas e projetos, serviços e benefícios que trabalham com as famílias do PBF na rede local;

- Trabalhar com o binômio família/comunidade, contribuindo para a potencialização do território, das famílias no território e das redes de solidariedade social, melhorando a oferta de serviços, adequando-os às demandas do território, combatendo inclusive discriminações entre as famílias atendidas em virtude de sua situação específica no PAIF/PAIFE e/ou no PBF.

O acompanhamento familiar é destinado às famílias que apresentam situações de vulnerabilidades e violação de direitos e requerem a proteção da assistência social para garantia de acesso aos direitos socioassistenciais e ampliação de sua capacidade protetiva. Para isso, demanda uma atenção diferenciada, um olhar mais atento dos profissionais do CRAS, na medida em que essas situações vivenciadas, caso não sofram imediata intervenção profissional, podem tornar-se risco social e/ou violação de direitos.

Trata-se de um processo de caráter continuado e planejado, por período de tempo determinado, no qual se definem os objetivos a serem alcançados, a partir de vulnerabilidade e risco, demandas e potencialidades apresentadas pelas famílias. No âmbito do PAIF/PAEFI, tem como finalidade enfrentar as situações de vulnerabilidade e risco social; prevenir a ocorrência de riscos e/ou violações de direitos; identificar e estimular as potencialidades das famílias na sua função protetiva; afiançar as seguranças de assistência social e promover o acesso das famílias e seus membros a direitos, sejam eles civis, políticos, sociais, econômicos, culturais e ambientais.

O acompanhamento familiar consiste, assim, num conjunto de intervenções desenvolvidas de forma continuada, a partir do estabelecimento de compromissos entre famílias e profissionais, com a construção de um plano de 
acompanhamento familiar que estabelece objetivos a serem alcançados, a realização de mediações periódicas, a inserção em ações a fim de superar gradativamente as vulnerabilidades e riscos vivenciados e o acesso a direitos. Objetiva, ainda, contribuir para ampliar espaços de participação e diálogo com instituições e para o alcance de maiores graus de autonomia, para a capacidade de vocalização das demandas e necessidades e para o desenho de projetos de vida.

Em decorrência de situação de vulnerabilidade, devem ser priorizadas no acompanhamento:

- Famílias contrarreferenciadas ao CRAS pelo CREAS, após trabalho realizado pelo PAEFI com famílias e indivíduos;

- Famílias com beneficiários do BPC de até 18 anos, fora da escola, devido às seguintes barreiras: ausência de acompanhamento para levar o beneficiário até a escola; ausência de iniciativa da família para estimular o convívio sociofamiliar; ausência de cuidadores familiares; dificuldade dos beneficiários e da família em acessar a rede de serviços;

- Famílias cujo descumprimento de condicionalidades do Programa Bolsa Família (PBF) decorre de situações de vulnerabilidade social ${ }^{77}$;

- Famílias do Rio Sem Miséria (Programa Renda Melhor e Renda Melhor Jovem);

- Demais famílias que, segundo avaliação dos profissionais, requerem processo de acompanhamento familiar para desenvolvimento de capacidades, acesso a direitos, proteção de um ou mais de seus membros, bem como superação das situações de vulnerabilidade vivenciadas, conforme realidade local.

É fundamental que atividades de acompanhamento familiar com as famílias beneficiárias do Programa Renda Melhor ocorram em estreita articulação com as coordenações municipais de saúde e educação, com o setor responsável pela manutenção e gerência do Cadastro Único, quando este for centralizado, e com os agentes de gestão de oportunidades econômicas e sociais-GOES. 
É muito importante alcançar aqueles que não acessam os serviços públicos e vivem fora de qualquer rede de proteção social. No âmbito do Plano Rio Sem Miséria, a Busca Ativa é um desafio a ser alcançado, por meio do estabelecimento de ações e estratégias para identificação e cadastramento das famílias que encontram-se na pobreza extrema, ou seja, que vivem com renda per capita estimada inferior a $\mathrm{R} \$ 100$.

A gestão municipal tem a autonomia para planejar a melhor forma de organização territorial, adoção de estratégias e metodologias adequadas com o objetivo de alcançar as famílias que constituem a parcela da população mais vulnerável, sendo necessário ao poder público conhecê-las e incluí-las no Cadastro Único, ação esta denominada de Busca Ativa.

No processo de Busca Ativa, ao conhecer as famílias em extrema pobreza, as Gestões Municipais encontrarão diversas situações de vulnerabilidade social. É muito recorrente a identificação de famílias e pessoas com subregistro ${ }^{78}$ de nascimento e ausência de documentação civil básica, por exemplo.

O município deverá realizar o cadastramento também para pessoas e famílias sem registro civil, com o objetivo de possibilitar que o poder público visualize a situação local existente, de modo a subsidiar a elaboração de diagnósticos e a formulação de estratégias com vistas ao combate e à erradicação do sub registro de nascimento, bem como a emissão da documentação básica para pessoas integrantes das famílias nessa situação.

Ressalta-se que, dentre as famílias em situação de extrema pobreza no Estado do Rio de Janeiro, as pertencentes aos grupos populacionais tradicionais e específicos devem receber atenção prioritária na formulação de estratégias para Busca Ativa. No momento em que essas famílias são cadastradas e corretamente identificadas no Cadastro Único, o poder público poderá desenvolver políticas e programas focalizados, permitindo a definição de ações mais efetivas para a superação da miséria.

\footnotetext{
${ }^{78}$ É considerável o número de pessoas com subregistro no estado do Rio de Janeiro: somente na região metropolitana, são mais de 28 mil pessoas, de acordo com o IBGE (2013).
} 
De acordo com o Guia para a Gestão Municipal do Programa Renda Melhor (2014, p.79) são importantes ações da Gestão Municipal para o desenvolvimento da busca ativa:

- Identificar e incluir no Cadastro Único as famílias em extrema pobreza necessita de investimento em estratégias de atualização cadastral, tendo em vista que o Cadastro Único atualizado reflete a realidade sócio econômica das famílias;

- Concentrar as ações de Busca Ativa nas áreas do município que tenham bolsões de pobreza;

- Identificar corretamente no Cadastro Único as famílias que pertencem a povos e comunidades tradicionais e específicas é fundamental para garantir o planejamento de políticas públicas voltadas para estes grupos. A Portaria $\mathrm{n}^{\mathrm{o}}$ 177/2011 propõe um cadastramento diferenciado para famílias indígenas, quilombolas, extrativistas, em situação de rua, entre outros grupos;

- Garantir a identificação e o cadastramento de todas as famílias em situação de vulnerabilidade socioeconômica, principalmente as que residem em áreas remotas e as que vivem em regiões urbanas marcadas pela violência. Para que o poder público chegue a essas famílias é necessário o estabelecimento de parcerias com ONG's, organizações da comunidade, entre outros. 


\section{5 \\ Plano Rio Sem Miséria como estratégia para a redução da pobreza: resultados de um estudo de caso}

\section{1. \\ Contextualização do estudo de caso sobre o Plano Rio Sem Miséria}

No contexto da pesquisa sobre o Plano Rio Sem Miséria, cujos resultados do estudo são referentes a análise da estratégia como meio para a redução da pobreza no estado do Rio de Janeiro, são objetos de destaques determinados aspectos que nos permitem identificar se de fato as estratégias que compõem o Plano podem ser consideradas como fatores contribuintes para o objetivo ao qual foram criadas.

Para isso, foi desenvolvido um estudo empírico no Estado do Rio de Janeiro, por meio de um estudo de caso qualitativo, explicitado na introdução desta dissertação. Também na referida introdução, foi destacada a utilização da técnica do estudo de caso para o desenvolvimento da dimensão empírica da pesquisa bem como foram apresentadas as categorias chaves e as questões perguntas que foram consideradas para orientar o presente estudo.

A metodologia do estudo de caso nesta pesquisa foi uma opção escolhida em função do objeto de estudo, o Plano Rio Sem Miséria, ser amplo e complexo, onde o corpo de conhecimentos existente é insuficiente para suportar a proposição de questões causais e nos casos em que o fenômeno não pode ser estudado fora do contexto onde naturalmente ocorre, (Bonoma, 1985), como é o caso desta pesquisa.

As reflexões provenientes do estudo de caso nos permitem auferir que esta metodologia, de acordo com Tull (1976, p 323) "refere-se a uma análise intensiva de uma situação particular". Portanto, o presente estudo tem como foco a análise ampla das questões relacionadas ao Plano Rio Sem Miséria destacando os seguintes aspectos, que são também as nossas questões perguntas:

- Antecendentes do PRSM; 
- Estrutura estadual para a execução do PRSM;

- Gestão do Plano;

- Gestão Municipal;

- Articulação com PBF;

- Articulação com o Plano Brasil Sem Miséria;

- Articulação com a Política de Assistência Social;

- PPRSM e a redução da pobreza: cadeia de evidências; a

- Desafios para o Plano;

Com base no estudo de caso, tendo como referência as questões perguntas, o quadro analítico tendo como referência Kingdon, foi possível identificar uma cadeia de evidências que comprovam as suas contribuições na redução da pobreza no estado do Rio de Janeiro, assim como os desafios e as perspectivas futuras do Plano.

É importante destacar que o conteúdo do presente capitulo contém o registro e a problematização dos resultados da pesquisa empírica.

\section{2. Apresentação e análise dos resultados do estudo de caso sobre o Plano Rio Sem Miséria}

Considerando as variáveis e os indicadores que orientaram o trabalho de campo, mediante o desenvolvimento da técnica de estudo de caso, apresentados na introdução desta pesquisa, têm-se os resultados a seguir considerados por meio da pesquisa do Plano de enfretamento á pobreza, o Plano Rio Sem Miséria, no Estado do Rio de Janeiro. 


\section{Implantação do Rio sem Miséria}

Ao tecermos as ponderações sobre o contexto de implantação do Plano Rio Sem Miséria levaremos em consideração o cenário nacional e o cenário do Estado do Rio de Janeiro.

Com relação ao cenário nacional, temos como perspectiva inicial as mudanças trazidas pela Constituição Federal de 1988, onde os entes federados passam a ter a responsabilidade juntamente com o governo federal na elaboração de ações para o combate a pobreza no Brasil. ${ }^{79}$

Além disso, constitui-se a partir da aprovação da carta magna a formalização da seguridade social no Brasil, composta pela Saúde, Previdência Social e Assistência Social, como direito do cidadão e dever do estado.

Observa-se ainda que o Brasil tem se destacado, no período recente, pela redução da pobreza - especialmente a extrema pobreza. Este resultado deve-se a um conjunto de fatores, que vão desde a recuperação do salário mínimo, passando pela crescente incorporação de trabalhadores no mercado formal de trabalho, com o aumento do número de empregos, até a consolidação do Sistema Único de Assistência Social- SUAS, que é a materialização da política de Assistência Social e o Programa Bolsa Família - PBF.

O SUAS busca integrar as políticas de Assistência Social num modelo racional, equitativo, descentralizado, participativo e com financiamento compartilhado entre os entes federados. É um sistema público, não contributivo, que tem por função a gestão e a organização da oferta de benefícios e serviços da assistência social.

A convergência entre os benefícios e os serviços da Assistência Social proporcionou avanços no que se refere à superação da pobreza: foram mais de 28 milhões de pessoas que saíram da situação de pobreza extrema(IBGE/2010). Mas mesmo diante dos resultados, 16,2 milhões de pessoas permaneceram na condição de extrema pobreza (IBGE/2010), demonstrando que as políticas públicas implementadas não foram suficientes e mostraram-se de difícil acesso para as camadas mais pobres da população, sendo incapazes de reverter a situação de

\footnotetext{
${ }^{79}$ Vide capítulo 2.
} 
extrema pobreza de muito brasileiros. E neste contexto, o governo da Presidente Dilma Rousseff, ciente da limitação da política aplicada, apresenta o Plano Brasil Sem Miséria (PBSM) em junho de 2011, com o objetivo de erradicar a extrema pobreza no Brasil até o final de 2014. No mesmo momento, conclama os governos subnacionais a criarem seus planos de superação da pobreza.

Alinhado a estratégia do Governo Federal e mediante um cenário de pobreza e desigualdade, o governo do Estado do Rio de Janeiro criou o Plano Rio Sem Miséria - PRSM, que consiste no Plano Estadual de Superação da Pobreza do estado do Rio de Janeiro.

Vale ressaltar que não utilizaremos a nomemclatura superação de pobreza pelo fato de concordamos como Neto (2003) e Iamamoto (2001) que apontam nas suas reflexões que no modo de produção capitalista não há superação da pobreza, mas sim a redução da pobreza.

Além da orientação do Governo Federal, o contexto de pobreza e desigualdades do estado do Rio de Janeiro também foi decisivo para a elaboração do Plano Estadual. Na última década, enquanto nos outros estados da região sudeste, o índice de Gini segue em uma tendência de queda, no Rio de Janeiro o índice permanece estagnado, demonstrando que o crescimento econômico não implica na justa distribuição de renda e na redução das desigualdades. E, mesmo com a terceira maior renda per capita média entre os estados brasileiros e o segundo maior PIB dos pais, de acordo com o censo IBGE/2010, mais de 586 mil pessoas ainda vivem com renda per capita inferior a $\mathrm{R} \$ 77,00$, colocando o Estado em $17^{\circ}$ no ranking das desigualdades entre os estados brasileiros.

No que se refere aos indicadores de educação, o cenário do Estado do Rio de Janeiro é de baixo desempenho. Em 2010, o Rio de Janeiro ocupava o penúltimo lugar, com melhora significativa, passando para o $15^{\circ}$ lugar em 2011, no que se refere ao Índice de Desenvolvimento da Educação Brasileira. No ensino médio, a distorção idade/série é de 43,5\%, o índice de reprovação é de $18,9 \%$ e o índice de abandono por parte dos alunos do ensino médio, de 12,8\%, considerado alto pelos especialistas da área de educação.

É justamente neste contexto de extrema pobreza persistente que o PRSM tem suas estruturas basilares de atuação: a partir da compreensão da necessidade 
de um conjunto de ações articuladas para enfrentar os múltiplos determinantes da pobreza, visto que o Plano parte da premissa de que a pobreza extrema não se refere apenas a insuficiência de renda, mas da desigualdade, composta por um conjunto de fatores dentre os quais podemos citar o desigual acesso às políticas públicas e as oportunidades sociais e econômicas, presentes nas diversas dimensões da vida das famílias e das pessoas.

O contexto do estado do Rio de Janeiro com suas desigualdades, bem como um cenário de ampliação da pobreza e das desigualdades requer a implantação de Planos como o Rio Sem Miséria, com o objetivos de ações para a melhoria nas condições de vida das populações, prevendo estratégias de ampliação de renda, bem como o acesso as oportunidades econômicas e sociais.

Por meio do estudo de caso apura-se a necessidade e a pertinência do Plano Rio Sem Miséria como uma das ações para a redução da pobreza no Estado, salientado que o mesmo pode contribuir de forma eficiente este fm.

\section{Sobre a estrutura estadual para a execução do Plano Rio sem Miséria}

O objetivo deste eixo de análise de resultados é apontar na estrutura organizacional do Governo do Estado do Rio de Janeiro o(s) setor (es) ou órgão(s) responsável(eis) pela implantação, execução e acompanhamento do PRSM. Busca-se dessa forma analisar de que forma essa estrutura tem contribuído no processo de execução do programa no Estado.

No que se refere às Gestões Municipais, faremos um levantamento, bem como uma análise prévia sobre as estruturas responsáveis pela gestão do PRSM na esfera local. ${ }^{80}$

No Estado do Rio de Janeiro, a secretaria responsável pela gestão do Plano Rio Sem Miséria é a Secretaria de Estado de Assistência Social e Direitos Humanos-SEASDH. A escolha desta Secretaria se deu pelo fato desta ser a mais articulada com o MDS. No país, existem atualmente $19^{81}$ planos de Superação a

\footnotetext{
${ }^{80} \mathrm{O}$ objetivo aqui não é esse, porém há a necessidade de traçarmos algumas considerações para a compreensão de da forma como é estruturada a gestão do PRSM.

${ }^{81}$ De acordo com IPEA, 2014.
} 
Pobreza e a grande maioria ${ }^{82}$ destes planos $(85 \%)$ está sob a responsabilidade das Secretarias Estaduais de Assistência Social.

"Como o Programa nacional, o Brasil Sem Miséria, no qual o plano estadual foi referenciado é responsabilidade precípua do Ministério de Desenvolvimento Social, foi decisão do governador, que no estado do Rio de Janeiro, o plano ficasse na SEASDH, mais especificamente na Subsecretaria de Integração de Programas, a SSIPS". ( Antonio Claret, Formulador e Gestor do PRSM)

A SEASDH é responsável pela Política Pública de Assistência Social no estado do Rio de Janeiro. Além disso tem como responsabilidades a política de Segurança Alimentar, Transferência de Renda e Promoção da Cidadania e Direitos Humanos no Estado.

"No seu espectro de atribuições a SEASDH tem como diretrizes fundamentais a o combate às consequências geradas pela pobreza, como por exemplo a exclusão social; a garantia e a promoção do acesso às políticas públicas consideradas essenciais para a vida do cidadão como por exemplo a educação, a saúde, a segurança, o cultura, o esporte, o lazer e a habitação; assim como o desenvolvimento de uma política de inclusão social para as camadas mais pobres da população do Estado, aquelas que estão em situação de extrema pobreza". ( Antonio Claret, Formulador e Gestor do PRSM)

De acordo com a legislação em vigor no Estado, esta preconiza que compete à SEASDH as seguintes atribuições:

“- Formular, coordenar e executar as políticas públicas referentes à Assistência Social, Segurança Alimentar, Transferência de Renda, Promoção dos Direitos Humanos e Cidadania, em articulação com órgãos e entidades da administração federal, estadual e municipal, bem como com entidades não-governamentais;

- Planejar, organizar, dirigir e controlar o Sistema Estadual de Assistência Social, observando a legislação vigente, em especial a do Sistema Único de Assistência Social;

- Gerir os recursos destinados aos Fundos Estaduais voltados para as ações de Assistência Social e Direitos Humanos, os quais possuem finalidades e competências estabelecidas na legislação que dispõe sobre sua organização e funcionamento;

- Destinar recursos financeiros aos Municípios, a título de participação no custeio do pagamento dos auxílios natalidade e funeral, mediante critérios estabelecidos pelos Conselhos Estaduais de Assistência Social;

${ }^{82}$ De acordo com IPEA,2014. 
-Apoiar técnica e financeiramente os serviços, os programas e os projetos de enfrentamento da pobreza em âmbito regional ou local;

- Atender, em conjunto com os Municípios, às ações assistenciais de caráter de emergência;

- Estimular e apoiar técnica e financeiramente as associações e os consórcios municipais na prestação de serviços de assistência social e direitos humanos;

- Prestar os serviços assistenciais cujos custos ou ausência de demanda municipal justifiquem uma rede regional de serviços, desconcentrada, no âmbito do Estado do Rio de Janeiro. (<http://www.rj.gov.br/web/seasdh/exibeconteudo?articleid=140843>, acesso em 16 fev. 2015).

$\mathrm{Na}$ estrutura da SEASDH, há a Subsecretaria de Integração de Programas Sociais, cujas atribuições consistem na responsabilidade pela execução do Programa Bolsa Família, do Cadastro Único e a ela foi atrelada a responsabilidade pela implantação, execução e acompanhamento do Plano Rio Sem Miséria.

“ Por ocasião da primeiras discussões para a implantação o Plano Brasil Sem Miséria, o governador Cabral nos chamou e pediu que formássemos uma equipe para a criação e execução de Plano de superação a pobreza no Estado. Orientou também que SSIPS fosse a responsável pela criação, implantação e execução do Plano no Estado." (Antônio Claret, Formulador e Gestor do PRSM)

A SSIPS é formada por duas superintendências: a Superintendência de Renda de Cidadania, que tem como responsabilidades a coordenação estadual do Programa Bolsa Família, do Cadastro Único e do Programa Renda Melhor; a Superintendência de Gestão de Oportunidades, que coordena o Programa Renda Melhor Jovens e o GOES.

A estratégia do PRSM referente ao Fortalecimento do SUAS é responsabilidade da SEASDH, ou seja, todos os envolvidos na execução da Política de Assistência Social. A estratégia de Acompanhamento Familiar é de responsabilidade compartilhada entre a Subsecretaria de Assistência Social e Gestão do SUAS (SSASG) e da SSIPS.

O Programa Renda Melhor Jovem tem como especificidade o fato de ser executado em conjunto entre a SSIPS - Superintendência de Gestão de Oportunidades e a Secretaria de Estado de Educação, pela Coordenadoria de Controle de Frequência Escolar e Programas Sociais - CCFEPS. A cada um 
cabem atribuições específicas, conforme podemos observar nas discussões do capitulo 4, item 4.4 .

\begin{abstract}
"A gestão compartilhada com a SEEDUC para a execução do Renda Melhor Jovem é necessária, visto que os alunos estão nas escolas, que são os equipamentos sociais da educação. Além disso, é educação que possui as informações sobre as escolas e séries dos alunos, assim como o contato permanente com os mesmos, bem como os seus familiares, nas reuniões de pais e mestres. Além disso, os escpaços físicos, as escolas e suas estruturas, podem ser utilizadas para as ações compartilhadas do GOES e do Renda Melhor Jovem". (Luis Gustavo, Superintendente de Gestão de Oportunidades)
\end{abstract}

As estratégias do Plano Rio Sem Miséria, apesar de estarem centradas na SEASDH/SSIPS tem como diretriz central a articulação para a sua execução com as demais secretarias e órgãos do Estado.

\begin{abstract}
"A articulação com as demais secretarias e órgãos do Estado é fundamental e necessária para a execução do Plano Rio Sem Miséria, do contrário não será possível expandir o programa e atingir a totalidade do público pretendido. A exemplo do que ocorre com o Programa Bolsa Família é necessário um conjunto articulado de ações intersetoriais também no PRSM." (Antonio Clartet, Formulador e Gestor do PRSM)
\end{abstract}

A articulação e ações intersetoriais estabelecidas para a execução do Plano não ocorrem de maneira frequente e necessária. Observa-se que a SSIPS centraliza e coordena as atividades do Plano, sem conseguir realizar ações compartilhadas com demais órgãos e secretarias do Estado, a exceção da SEEDUC, no caso do Renda Melhor Jovem.

“ Um dos grandes desafios do PRSM consiste na integração e articulação com as demais secretarias e órgão do governo do estado, para a execução da estratégias do Plano, apresar da previsão para que esta ocorra, ainda é uma grande desafio." (Antonio Claret, Formulador e Gestor do PRSM)

Um plano como o Rio Sem Miséria que prevê a superação da pobreza não pode ter a sua estrutura de gestão concentrada em apenas uma Secretaria. Deve, desde a sua concepção, prever a integração bem como indicar como esta deve ser efetuada, para que seja possível a consecução dos seus objetivos. 
Da maneira como vem sendo executado, percebemos que o Plano precisa ser uma ação do Estado, confirme previsto na sua concepção e não apenas o plano executado por uma Subsecretaria. Nesse caso, presenciamos o que podemos chamar de ótimo abstrato e péssimo concreto. Ou seja, com relação a sua concepção o PRSM prevê as preposições de articulação e integração como premissas fundamentais, porém na prática isso não ocorre. O que de fato ocorre na prática são ações isoladas e pontuais duma Subsecretaria e não um conjunto de ações compartilhadas de todos os segmentos administrativos do Governo do Estado.

Para poder avançar, não é necessário a alteração das concepções do Plano ou de qualquer aspecto na sua formulação com relação a esse ponto, porém, pe necessário que seja previsto um conjunto de ações e o plano para efetuá-los no sentido de tornar o PRSM um plano do Governo do Estado do Rio de Janeiro, apreendido e executados por todas as suas secretarias e órgãos, em articulação com o setor privado e com a sociedade civil.

\section{O papel da Gestão Municipal no Plano Rio Sem Miséria}

A Gestão Municipal é fundamental para a execução das ações do Plano Rio Sem Miséria, visto que é nos municípios que de fato ocorre a gestão do programa, pois é nestes que as famílias são atendidas e que as ações são operacionalizadas.

Por ocasião da implantação do Plano ocorrida em 2011, três municípios fizeram parte do projeto piloto de implantação do PRSM: Belford Roxo, Japeri e São Gonçalo, por pertencerem á região metropolitana, com elevado contingente populacional, bem como por possuírem baixos Índices de Desenvolvimento Humano (IDH).

Em 2012, mais $49^{83}$ municípios passaram a fazer parte do Plano Rio Sem Miséria.

\footnotetext{
${ }^{83}$ Macaé em marco/2012 e os demais municípios em julho/212.
} 
“Em 2012, por ocasião da expansão do Plano Rio Sem Miséria, os municípios com baixos IDH passaram a fazer parte do Plano. Nesse momento, incluímos também os municípios que foram atingidos pela tragédia das chuvas no final de 2011 e que declaram situação de calamidade pública. Esses municípios foram profundamente abalados social e economicamente pela tragédia que ficou nacionalmente conhecida." (Antonio Claret, Formulador e Gestor do PRSM)

"Com a expansão do Plano em junho/2013, todos os municípios do Estado passaram a ser atendidos pelo PRSM. No caso do município do Rio de Janeiro, o mesmo também passou a ser atendido pelo Plano Rio Sem Miséria, com exceção da estratégia do Programa Renda Melhor, em função do mesmo possui um programa municipal de transferência de renda, o Cartão Família Carioca. (Ana Vieira, Superintendente de Renda de Cidadania)

O processo estabelecido entre o Estado do Rio de Janeiro e os municípios para a implantação do PRSM na esfera local, foi marcada inicialmente por contato telefônico aos prefeitos municipais e a gestão municipal de Política de Assistência Social em junho de 2011. Nesse momento, foi, então, apresentada a proposta do Plano Rio Sem Miséria e as suas estratégias, inicialmente a do Renda Melhor e do Renda Melhor Jovem para os mesmos, a partir dai os municípios assinando o Termo de Adesão ao Programa Renda Melhor com o Governo do Estado.

Como podemos identificar, não ocorreu a assinatura do Termo de Adesão ao Plano Rio Sem Miséria, mas sim somente ao Programa Renda Melhor, conforme podemos observar nos anexos desta pesquisa.

Ou seja, o instrumento de adesão do Plano Rio Sem Miséria para os municípios na verdade não foi um instrumento de adesão ao Plano estadual, mas somente a adesão ao Programa Renda Melhor, uma das estratégias do Plano nos mesmos moldes da adesão que os municípios efetuaram por ocasião da adesão ao Programa Bolsa Família com o Governo Federal. ${ }^{84}$

\section{Programa Renda Melhor}

De acordo com o Termo de Adesão assinado entre os municípios e o Governo do Estado do Rio de Janeiro, são atribuições das Gestões Municipais:

I. Delegar ao gestor municipal do Programa Bolsa Família - PBF, as seguintes atribuições: 
a) gestão e coordenação do Programa Renda Melhor;

b) interlocução com a instância local de controle social dos Programas Bolsa Família e Renda Melhor;

c) promover a integração do Programa Renda Melhor com as áreas de saúde, educação, trabalho, assistência social, segurança alimentar, desenvolvimento social dentre outras, quando existentes, visando o desenvolvimento das ações do Programa no âmbito municipal e estadual;

d) articulação com o governo estadual; e

e) promover estratégias de busca ativa de famílias, articulado com a SEASDH, para entrega de cartões do Programa Bolsa Família/Renda Melhor não entregues.

II. delegar a responsabilidade para realizar o controle social do Programa Renda Melhor ao conselho ou comitê de controle social do Programa Bolsa Família;

III. realizar a gestão dos benefícios do Programa Renda Melhor às famílias que residem em seu território;

IV. promover, em articulação com os governos estadual e federal, o acesso dos beneficiários do Programa Renda Melhor aos serviços de educação e saúde, a fim de permitir o cumprimento das condicionalidades pelas famílias beneficiárias;

V. proceder ao acompanhamento das famílias beneficiárias, em especial atuando nos casos de descumprimento de condicionalidades e outras situações indicativas de vulnerabilidade e de risco social;

VI. estabelecer parcerias com órgãos e instituições municipais, estaduais e federais, governamentais e não governamentais, para a oferta de um cardápio de oportunidades econômicas e sociais aos beneficiários do Programa Renda Melhor, especialmente ações de alfabetização, de capacitação profissional e de geração de emprego e renda desenvolvidas em sua esfera de competências.

${ }^{84}$ De acordo com a Portaria GM 246/2005. 
VII. Reiterar os seguintes compromissos assumidos em pactuação com o Governo Federal para a implementação do Programa Bolsa Família, principalmente:

a) implementar ações de busca ativa com o objetivo de identificar e incluir no Cadastro Único para Programas Sociais todas as famílias em situação de pobreza extrema;

b) realizar o acompanhamento familiar de todas as famílias beneficiárias do Programa Renda Melhor, utilizando os instrumentos informacionais disponíveis e os que serão disponibilizados pelo Estado do Rio de Janeiro;

c) promover a apuração e/ou o encaminhamento, às instâncias cabíveis, de denúncias sobre irregularidades na execução do Programa Renda Melhor no âmbito local;

VIII. Reiterar os seguintes compromissos assumidos em pactuação com o Governo Federal no Protocolo de Gestão Integrada Serviços, Benefícios e Transferência de Renda no âmbito do SUAS :

a) Mapear a ocorrência de situações de vulnerabilidade e riscos, bem como a rede sócio assistencial e das demais políticas setoriais;

b) Atualizar periodicamente o mapeamento das famílias beneficiárias do PBF e do Programa Renda Melhor, com base nas informações disponibilizadas pelo Ministério do Desenvolvimento Social - MDS e pela SEASDH;

c) Acessar o Sistema de Gestão do Programa Bolsa Família (SIGPBF) e obter as informações das famílias beneficiárias em descumprimento de condicionalidades para a realização do acompanhamento familiar;

d) Disponibilizar aos CRAS ou, onde não houver, para a equipe técnica da Proteção Social Básica - PSB responsável pela implementação da Gestão Integrada, a relação de famílias do PBF e do Programa de Erradicação do Trabalho Infantil - PETI residentes em seu território de abrangência, para o acompanhamento das famílias; 
e) Disponibilizar ao CRAS e ao CREAS ou, onde não houver, para a equipe técnica da PSB e da Proteção Social Especial - PSE, a relação completa de famílias do PBF e do PETI em situação de descumprimento de condicionalidades pelos motivos relacionados à proteção básica e à proteção especial;

f) Fortalecer o papel de gestão territorial da PSB do CRAS, bem como de oferta, articulação e de referência dos serviços sócio assistenciais nos territórios e para tanto: instituir, nos termos dos convênios firmados, que as entidades prestadoras de serviços sócio assistenciais do território destinem ao menos $60 \%$ (sessenta por cento) de sua capacidade de atendimento aos usuários encaminhados pelo CRAS;

Percebemos que, as atribuições dos municípios estabelecidas na adesão, não se referem ao Plano Rio Sem Miséria mas aos Programa Renda Melhor e seus beneficiários. Ainda nos compromissos assumidos pelos municípios aparecem ações relacionadas ao PBF, Cadastro Único, Acompanhamento Familiar, Busca Ativa e Fortalecimento do SUAS, por meio do reforço às ações pactuadas no Pacto de Aprimoramento da Gestão do SUAS, assinado por todos os municípios fluminenses. Com relação ao Programa Renda Melhor e ao GOES não há compromisso explícitos para as Gestões Municipais.

Na expansão do Plano, ocorrida em 2012, os 48 municípios também foram previamente contatados e ocorreu o lançamento do Programa Renda Melhor e Renda Melhor Jovem nos mesmos. Já na 2a expansão, ocorrida em 2013, os municípios foram apenas informados de que ocorreria a expansão do Programa Renda Melhor e Renda Melhor Jovem e foram convidados para participar de eventos regionais de lançamento dos mesmos.

Ao total foram realizados 13 eventos regionais de lançamento do Programa Renda Melhor e Renda Melhor Jovem no Estado, sendo que tivemos oportunidade de participar de 8 deles.

Os eventos contaram com a presença do Governador do Estado, Secretário de Estado de Assistência Social e Direitos Humanos, autoridades do Estado e dos municípios, bem como famílias beneficiárias que receberam informações sobre os 
Programas. Alguns beneficiários contemplados receberam o cartão simbólico do PRM e do Renda Melhor Jovem nos eventos.

Observamos que no processo de adesão dos municípios ao PRM, bem como nos eventos de lançamento, houve um protagonismo do Estado, sendo o município incorporado em algo verticalizado, que foi nível estadual para municipal. A ideia do Plano e das suas estratégias foi estadual e os municípios só incorporam essa ideia sem discussão prévia sobre o seu modelo, implantação e gestão.

Em suma, as Gestões Municipais passaram a fazer parte do Plano Rio Sem Miséria por meio da adesão ao Renda Melhor, sem uma adesão formal ao Plano, no que se refere ao PRMJ e ao GOES, estratégias igualmente importantes e que podem contribuir de forma decisiva para a redução da pobreza no Estado.

\section{Programa Renda Melhor Jovem}

Não há o estabelecimento das atribuições para a Gestão Municipal em guiais, manuais e na legislação.

$\mathrm{Na}$ entrevista com o Superintendente de Gestão de Oportunidades, Luis Gustavo, o mesmo nos passou as informações referentes ao papel da Gestão Municipal, para a execução das ações do PRMJ.

As ações no município, de acordo com o superintendente estão centradas na Assistência Social, que deverá desenvolver as seguintes atividades:

1. Manter atualizado o Cadastro Único e realizar o acompanhamento familiar;

2. Estimular os jovens e as famílias a participarem do RMJ;

\footnotetext{
"A importância da melhoria da escolaridade e da qualificação profissional como caminho para superação da pobreza é um dos aspectos que necessita se destacado". (Luis Gustavo, Superintendente de Gestão de Oportunidades)
}

3. Orientar os jovens e as famílias sobre as regras do Programa; 
4. Promover a inclusão documental das famílias, em especial dos jovens do programa e seus responsáveis (Certidão de nascimento, Carteira de Identidade e CPF);

5. Colaborar na comprovação do endereço e regularização fundiária;

6. Oferecer oportunidades adicionais aos jovens do programa

7. Promover o acesso à cultura, ao esporte e ao lazer

8. Orientação e capacitação para inclusão produtiva dos jovens

9. Acesso à qualificação profissional - Pronatec, Faetec, outros Junto com a secretaria de trabalho, apoiar a inclusão produtiva qualificada dos jovens - estágio, menor aprendiz, etc.

10. Inclusão de jovens em programas comunitários, etc.

11. Junto com a secretaria de educação, divulgar o RMJ nas últimas séries do ensino fundamental;

Além disso, salienta:

"As ferramentas que as Gestões Municipais possuem para a execução do Programa são : cartilha do RMJ para a Assistência Social, página do RMJ na internet e facebook e acesso a informações sobre a situação do jovem no programa: listagem dos jovens participantes; listagem dos jovens que não incluíram ou não possuem CPF; listagem dos jovens que não validaram as contas”. (Luis Gustavo, Superintendente de Gestão de Oportunidades)

Outra informação apontada pelo Superintendente é a necessidade do apoio que precisa ser prestado pelas escolas estaduais, bem como pelos parceiros tais como a área da prefeitura que cuida das políticas para juventude, a secretaria de trabalho, a secretaria de educação, as organizações e redes sociais locais, ONGs, o setor privado e demais atores do território para que o desenvolvimento das ações do PRMJ seja eficaz e pleno.

\section{Acompanhamento Familiar}

O município assume grande importância no Plano Rio Sem Miséria por meio do acompanhamento familiar e da Busca ativa para inclusão no Cadastro 
Único, de forma que o estado consiga estar mais próximo das famílias mais vulneráveis e que ainda estão abaixo da linha da extrema pobreza.

Dentre as ações principais desta estratégia, podemos destacar a Busca Ativa.

A Busca Ativa é muito importante alcançar aqueles que não acessam os serviços públicos e vivem fora de qualquer rede de proteção social. No âmbito do Plano Rio Sem Miséria, a busca ativa é um desafio a ser alcançado, por meio do estabelecimento de ações e estratégias para identificação e cadastramento das famílias que encontram-se na pobreza extrema, ou seja, que vivem com renda per capita estimada inferior a $\mathrm{R} \$ 100$.

A gestão municipal tem a autonomia para planejar a melhor forma de organização territorial, adoção de estratégias e metodologias adequadas com o objetivo de alcançar as famílias que constituem a parcela da população mais vulnerável, sendo necessário ao poder público conhecê-las e incluí-las no Cadastro Único.

No processo de Busca Ativa, ao conhecer as famílias em extrema pobreza, o poder público encontrará diversas situações de vulnerabilidade social. É muito recorrente a identificação de famílias e pessoas com sub registro de nascimento e ausência de documentação civil básica.

O município deverá realizar o cadastramento também para pessoas e famílias sem registro civil, com o objetivo de possibilitar que o poder público visualize a situação local existente, de modo a subsidiar a elaboração de diagnósticos e a formulação de estratégias com vistas ao combate e à erradicação do sub registro de nascimento, bem como a emissão da documentação básica para pessoas integrantes das famílias nessa situação.

Ressalta-se que, dentre as famílias em situação de extrema pobreza no Estado do Rio de Janeiro, as pertencentes aos grupos populacionais tradicionais e específicos devem receber atenção prioritária na formulação de estratégias para Busca Ativa. No momento em que essas famílias são cadastradas e corretamente identificadas no Cadastro Único, o poder público poderá desenvolver políticas e programas focalizados, permitindo a definição de ações mais efetivas para a superação da miséria. São ações fundamentais da busca ativa: 
- Identificar e incluir no Cadastro Único as famílias em extrema pobreza necessita de investimento em estratégias de atualização cadastral, tendo em vista que o Cadastro Único atualizado reflete a realidade sócio econômica das famílias;

- Concentrar as ações de Busca Ativa nas áreas do município que tenham bolsões de pobreza;

- Identificar corretamente no Cadastro Único as famílias que pertencem a povos e comunidades tradicionais e específicas é fundamental para garantir o planejamento de políticas públicas voltadas para estes grupos. A Portaria $n^{\circ}$ 177/2011 propõe um cadastramento diferenciado para famílias indígenas, quilombolas, extrativistas, em situação de rua, entre outros grupos; e

- Garantir a identificação e o cadastramento de todas as famílias em situação de vulnerabilidade socioeconômica, principalmente as que residem em áreas remotas e as que vivem em regiões urbanas marcadas pela violência. Para que o poder público chegue a essas famílias é necessário o estabelecimento o de parcerias com ONG's, organizações da comunidade, entre outro.

Outra ação dentro das estratégias do acompanhamento familiar é a atualização cadastral. A gestão municipal deve promover estratégias para a atualização cadastral contínua, visando conhecer com maior fidedignidade as informações socioeconômicas da população que se alteram continuamente.

O Governo Federal recomenda que as entrevistas sejam realizadas, prioritariamente, por meio de visita domiciliar, com pelo menos $20 \%$ das famílias cadastradas, com o objetivo de permitir a gestão municipal conhecer mais de perto a realidade social das famílias, além de reduzir a omissão de informações, sendo inclusive, um processo fundamental para as ações de fiscalização tanto do município quanto órgãos de controle externo.

Para o aprimoramento da gestão municipal do PBF e Renda Melhor é indicada a realização de visitas domiciliares como fundamental estratégia de cadastramento e atualização cadastral, pois possibilita ao entrevistador conhecer de perto a situação socioeconômica da família. Caso não seja possível realizar a 
visita domiciliar, o Gestor Municipal deve explicar ao RF a importância e os benefícios para a família em fornecer as informações corretas sobre a realidade.

À medida que as famílias são cadastradas e corretamente identificadas no Cadastro Único, o processo constante de atualização cadastral é fundamental para que o poder público conheça as famílias, da mesma forma que a ampla divulgação dos locais de atendimento às famílias permite-lhes ter acesso ao conjunto de ações ofertadas pelo poder público, tais como benefícios, serviços, programas e projetos.

Portanto, é fundamental a atuação da equipe multidisciplinar da Assistência Social nos municípios, por meio das visitas domiciliares, pois são eles que conhecem o território e possuem condições de realizar o acompanhamento sistemático às famílias e avaliar a situação vivenciada por cada família.

Nos casos em que há algum indício de divergência entre a realidade da família e a situação cadastral, em particular no que diz respeito à seleção para o Renda Melhor, a visita domiciliar é essencial para o processo de atualização cadastral com a maior grau de fidedignidade das informações registradas no Cadastro Único são condizentes com a realidade vivenciada por cada família. Nos casos em que há algum indício de divergência entre a realidade da família e a situação cadastral, em particular no que diz respeito à seleção para o Renda Melhor, a visita domiciliar é essencial para o processo de atualização cadastral com a maior grau de fidedignidade.

Para o processo de atualização cadastral as famílias devem levar em consideração os seguintes aspectos quanto ao prazo para a realização da referida ação:

- Sempre que houver qualquer alteração nos dados das famílias, especialmente quanto à composição familiar, endereço ou renda;

- Ou no prazo máximo de 24 meses contados da data da última entrevista.

O atendimento ás famílias é outra ação do acompanhamento familiar e, para realiza-la, a equipe municipal deve ter conhecimento da documentação orientadora sobre o PRSM. 
Desta maneira, possibilita toda a equipe a acolher e responder aos questionamentos das famílias, bem como tornar transparente e inequívoco o formato escolhido para o desenvolvimento do PRSM. Uma das frequentes perguntas direcionadas à gestão municipal está relacionada à alteração dos valores do benefício da folha raiz do Programa Renda Melhor vigente em relação à do ano anterior.

Analisando as informações obtidas na pesquisa realizada no Sistema de Gestão do Programa Renda Melhor, a gestão municipal poderá atender aos questionamentos da família, tornando claro o processo de geração da folha raiz do PRM quando avaliado em conjunto com as alterações do Programa Bolsa Família.

As ações a serem realizadas pela Grestão Municipal são as seguintes:

- Solicitar os dados básicos da família beneficiária: NIS e nome completo da RF do PBF/Renda Melhor;

- Acessar o Módulo de Consulta do Sistema deGestão do Programa Renda Melhor e realizar consulta para identificar o motivo da redução do valor do benefício;

- Acessar o Módulo de Consulta do Sistema de Gestão do Programa Renda Melhor e realizar consulta para identificar o motivo por não ter recebido o valor do RM;

A Troca do Responsável familiar também é uma das ações do Acompanhamento Familiar. É muito importante que o gestor municipal comunique imediatamente a troca do Responsável Familiar à Coordenação Estadual do PBF/Renda Melhor, para que o pagamento do RM não seja interrompido. Isso ocorre porque a CAIXA, no processo mensal de pagamento, identifica a divergência em relação ao NIS do Responsável Familiar (Folha Raiz versus Folha PBF) e não acata a informação de pagamento.

É importante destacar que, no caso do benefício do PBF, todas as vezes que a gestão municipal registra no Cadastro Único a troca do RF essa alteração é refletida automaticamente no Sistema de Benefícios (SIBEC). 
No caso do Programa Renda Melhor, para que esse reflexo também ocorresse de forma automática, a SEASDH realizou tratativas com o MDS e a CAIXA no sentido de solicitar o envio mensal de todas as ocorrências de "Troca de RF" registradas na base do Cadastro Único. Entretanto, o envio mensal das informações das trocas de RF ainda não foi sistematizado pela CAIXA. Diante deste contexto e com o intuito de regularizar com a maior brevidade possível o pagamento do benefício do Renda Melhor, o governo do estado do Rio de Janeiro criou um mecanismo de comunicação pelo qual, ocorrendo troca de RF referente a uma família beneficiá- ria do Renda Melhor, a Gestão Municipal imediatamente informa à SEASDH/ SSIPS a troca do RF à Coordenação Estadual do PBF/Renda Melhor, por meio de formulário específico e disponível para download no site <www.prm.rj.gov.br>.

\section{GOES}

As atribuições do GOES estão relacionadas ao mapeamento das oportunidades e demandas das famílias no território, porém não há o estabelecimento de um fluxo formal ou de uma relação ou definição das atribuições. É uma estratégia que precisa ser construída, em consonância com as diretrizes que a sustentam.

\section{Sobre a execução do Plano no Estado}

A execução Plano Rio Sem Miséria no estado do Rio de Janeiro segue os preceitos da descentralização administrativa e da autonomia dos entes, conforme estabelecido na Constituição Federal de 1988.

A Gestão Estadual é responsável pela coordenação do Plano no Estado. As gestões municipais, conforme vimos anteriormente é responsável pela execução do PRSM na esfera municipal. A seguir passaremos a detalhar alguns aspectos das estratégias individualmente. 


\section{Plano Renda Melhor}

A execução do Programa Renda Melhor no Estado é efetuada pela Superintendência de Renda de Cidadania, que também é responsável pela Coordenação Estadual do PBF e do Cadastro Único.

Observamos um conjunto compartilhado de ações entre o PBF, o Cadastro Único e PRM, por isso o êxito na execução desta estratégia de maneira acentuada. Ou seja, podemos afirmar que esta estratégia do PRSM é a que se encontra em plena execução, conforme o estabelecido na legislação.

Tal afirmação deve-se ao fato do Renda Melhor ser a única estratégia do PRSM que teve avanços significativos, ao quais destacamos:

- Expansão plena para todos os municípios do Estado, a exceção do município do Rio de Janeiro que possui estratégia própria, o programa Cartão Família Carioca;

- Plena integração com o PBF e o Cadastro Único;

- Criação de um fluxo para o Programa, sendo este plenamente seguido;

- Atribuições definidas para os atores envolvidos na execução do Programa;

- Parceria sólida com o Proderj, o que permite a geração da folha mensal de pagamento, bem como a revisão anual da folha raiz;

- Estabelecimento da parceria com o Ministério Público do Rio de Janeiro, como componente da rede pública de fiscalização para apuração de denúncias e irregularidades;

- Boa relação e proximidade com a gestões municipais;

- Parceria estabelecida com a CAIXA por meio de um Acordo de Cooperação Técnica para a execução das etapas da folha de pagamento bem como para o pagamento dos benefícios.

- Integração com as demais Superintendências da Secretaria, objetivando o desenvolvimento de ações compartilhadas, como por exemplo com a Superintendência de Proteção Social Básica, de Descentralização e 
Gestão do SUAS, com a Proteção Social Especial, Desigualdade Racial, com a Subsecretaria Especial de Políticas para Mulheres, dentre outras;

- Desenvolvimento e descentralização de Sistemas como o Sistema de Gestão do Programa Renda Melhor e do Portal do Plano Rio Sem Miséria, que permitiu o acesso das informações sobre o Programa para as Gestões Municipais;

- Ampla divulgação do Programa junto as gestões municipais e aos beneficiários;

- Boa articulação com COEGEMAS, CIB e CEAS;

Dentre os aspectos que necessitam ser aperfeiçoados, podemos citar a necessidade de ampliação da relação com o Ministério Público para ampliar as ações com o Ministério Público, bem como a ampliação das ações compartilhadas com as demais Secretarias e órgãos da Gestão Estadual.

Pode-se afirmar sem dúvidas que esta é única a estratégia do Plano Rio Sem Miséria que foi plenamente implantada e cujos objetivos, foram amplamente atingidos, assim como há o monitoramento e o acompanhamento das ações, conforme podemos observar por meio da pesquisa de campo.

\section{Plano Renda Melhor Jovem}

A execução do Renda Melhor Jovem está sob a responsabilidade da Superintendência da Gestão de Oportunidades, em parceria com a SEEDUC, mais especificamente a Coordenação de Controle de Frequência Escolar e Programas Sociais.

Com relação a parceria estabelecida com a SEEDUC, há ainda algumas dificuldades no que se refere ao fluxo para o envio das informações, o que é resolvido pela boa interlocução entre as secretarias.

Já a interlocução com o Banco do Brasil apresenta alguns desafios no que se refere falta de experiência da instituição bancária para a execução de políticas 
sociais a exemplo da CAIXA ${ }^{85}$, que tem essa expertise, com programas sociais para populações em situações de pobreza e extrema pobreza.

Apesar de ter objetivos, estratégias e fluxo operacional estabelecidos, podem ser constatadas algumas dificuldades expressivas para a execução do Programa Renda Melhor Jovem.

\begin{abstract}
"A complexidade do fluxo operacional, a presença de vários parceiros para a execução do mesmo, a contratação de uma instituição financeira sem plataforma social para o atendimento aos beneficiários, bem como sem experiência para atendimento de público-alvo de programas sociais e um conjunto complexo de ações que devem ser realizadas desde o inicio até o final do fluxo pelos beneficiários, implicam em um conjunto considerável de dificuldades consideráveis para a execução do Programa”.(Luis Gustavo, Superintendente de Gestão de Oportunidades)
\end{abstract}

Dentre as principais dificuldades relatadas pelo Superintendente de Gestão de Oportunidades, Luis Gustavo, podemos citar:

- O público alvo não está familiarizado com as regras do sistema financeiro;

- O produto bancário foi criado exclusivamente para o PRMJ, o que implica em dificuldades na operacionalização nas agências, visto que o Banco do Brasil não possui plataforma social nem expertise para o atendimento de beneficiários de programas sociais a exemplo da CAIXA;

- Comprovação de endereço: as famílias não possuem comprovante de endereço formal e o Banco do Brasil exige a comprovação para a abertura de conta. Pretende-se negociar com o banco para que seja possível aceitar por exemplo, para a comprovação de endereço uma declaração da associação de moradores;

- Ausência de documentação do jovem e do responsável familiar para a abertura da conta: inúmeros jovens não possuem condições de pagar a taxa de emissão do CPF. Para a emissão da primeira Carteira de

${ }^{85}$ Por ocasião da implantação do PRMJ, a CAIXA foi contantada para ser parceira do PRMJ, porém não manifestou interesse, visto a gama de programas do Governo Federal que estão sob sua responsabilidade. 
Identidade não há cobrança de taxas por parte do Governo do Estado do Rio de Janeiro;

- Dificuldades e custos da ida das famílias ao banco: para os casos em que a família necessita ir mais de uma vez ao banco, as despesas de deslocamentos tornam-se onerosas;

- Inconsistência dos dados cadastrais: Cadastro Único desatualizados, o cadastro da SEEDUC apresenta inconsistência e inconsistências junto a Receita Federal no que se refere ao CPF do aluno.

"As dificuldades para a execução do Programa consistem nos aspectos elencados acima e mais algumas questões operacionais pontuais. Para a resolução das mesmas serão realizados procedimentos e alterações no fluxo operacional do Programa". (Luis Gustavo, Superintendente de Gestão de Oportunidades)

As dificuldades centrais que acabam gerando resultados expressivos para a execução do programa consistem basicamente em aspectos relacionados a abertura das contas e as informações de escola e série desatualizadas no Cadastro Único.

Uma das soluções possíveis é pactuar com o Banco do Brasil a simplificação para o processo de abertura de contas. No que refere a atualização cadastral, são necessárias ações de mobilização para que as famílias mantenham suas informações cadastrais sempre atualizadas. Somente com estas ações não será possível avançar. É necessário um conjunto articulado de ações que vão desde alterações legais até o pleno acompanhamento das famílias para que os objetivos do Plano sejam atendidos.

\section{Gestão de Oportunidades Sociais}

Com relação ao GOES a execução do programa está sob a responsabilidade da Superintendência de Gestão de Oportunidades e sua execução está basicamente centrada no Pronatec-Brasil Sem Miséria e no Convênio Faetec.

As demais ações da estratégia estão sendo desenvolvidas de maneira branda, com exceção do Coletivo Coca Cola - PIT e do Convênio CIEE, realizado 
de maneira compartilhadas com a SEEDUC, onde esta exerce protagonismo sobre as ações.

Apreende-se que o GOES é uma estratégia que carece de aprimoramento quanto ao seu modelo teórico, bem como a elaboração de ações práticas para a sua execução. Dentre as principais dificuldades iniciais podemos apontar:

- O conceito de "oportunidades", os objetivos e a metodologia proposta para a estratégia de gestão para o GOES ainda não foram definidas de maneira objetiva, na concretude;

- Há questões básicas para a modelagem da metodologia do GOES que precisam ser respondidas tais como: o que são oportunidades econômicas e sociais? Quais são as oportunidades necessárias à superação da pobreza? Como mapear o perfil das famílias e suas demandas? Como mapear e induzir a oferta de oportunidades? Como mobilizar e levar as Oportunidades às famílias? Como monitorar resultados e avaliar impactos?

- As ações de oferta de oportunidades já implementadas pelo Governo do Estado do Rio de Janeiro, em parceria com diversas instituições governamentais e não-governamentais carecem de acompanhamento e monitoramento. A questão é estabelecer fluxos para esses processos.

- A estratégia de inclusão produtiva desenvolvida pelo Estado, precisa ser articulada entre as Secretarias e órgãos do Estado. É necessário criar mecanismos para que todos percebam a importância desta estratégia e o GOES possa ser protagonista da mesma;

É importante destacar que há lições aprendidas no eixo da gestão de oportunidades no Estado. Com relação as oportunidades presentes no Rio de Janeiro, podemos dizer que:

- Há a presença de espírito de iniciativa;

- Existem muitos ofertantes: públicos, sem fins lucrativos, privados;

- Existem muitas ofertas; as ofertas são muito diversificadas; existem muitas ofertas do governo estadual; há disponibilidade de recursos em várias instituições; rede de Assistência Social) 
Os principais desafios para a execução do GOES são os seguintes:

- Distribuição espacial não uniforme da oferta;

- Diferença de qualidade na oferta: em alguns locais quase não há oportunidades;

- Prevalece visão setorial das políticas, com objetivos específicos;

- Públicos e formas de acesso são diversos;

- Recursos direcionados a agendas específicas;

- Ausência da cultura de parceria - há pouca integração entre as secretarias de estado; há pouca integração entre as áreas da SEASDH;

- Dificuldade em compor recursos em parcerias;

- Capacidade de atuação dos municípios é muito diferenciada; diferentes capacidades nas secretarias municipais de assistência.

- O desafio de integrar os diversos setores e níveis de governo com o objetivo de superar a pobreza;

Pode-se afirmar que a estratégia do GOES é uma estratégia que ainda não foi plenamente implantada, necessitando de avanços e definições no que se refere aos seus aspectos teóricos, conceituais e legais, bem como na elaboração de um fluxo e de um modelo de interlocução com os setores capazes de ofertas oportunidades, com as Gestões Municipais e com as famílias que carecem das oportunidades.

\section{Acompanhamento Familiar}

A estratégia do acompanhamento familiar foi elaborada pela Subsecretaria de Assistência Social e Descentralização do SUAS. É importante lembrar que os CRAS e os CREAS materializam a Assistência Social e existem para garantir que todo cidadão que necessitar desta política possa acessá-la. No Estado do Rio de Janeiro, estas unidades estão abertas a toda e qualquer família que buscam atendimento, independentemente do motivo da procura.

Todas as famílias que procuram as unidades para atendimento devem ser primeiramente acolhidas, ouvidas e encaminhadas para o atendimento 
particularizado para receber retorno quanto ao motivo que as levou até lá. Estes são os procedimentos iniciais previstos pelo acompanhamento familiar.

As famílias acessam as Unidades de Referência da Assistência Social por demanda espontânea, por encaminhamentos de políticas setoriais, órgãos de defesa de direitos, ou pelo movimento de busca ativa da equipe no território. No caso das famílias acompanhadas no PAEFI, podem ainda ser encaminhadas por entidades que compõem o Sistema de Garantia de Direitos.

A orientação para registro das informações tem como ponto de partida o fluxo de atendimento, no CRAS, e o processo de Acolhida da Família ou de um de seus membros, no CREAS. Todas as famílias que acessarem essas unidades de Referência da Assistência Social, independentemente da forma de acesso, devem ser acolhidas por profissionais de nível médio ou pelo estagiário de Serviço Social ou de Psicologia, devidamente capacitados, e encaminhados para um primeiro atendimento pelo assistente social e psicólogo, de preferência no mesmo dia.

A estratégia de acompanhamento familiar no estado do Rio de Janeiro é uma estratégia muito bem desenhada e solidificada. Necessita de alguns avanços no que se refere a sua implementação e execução, especialmente no que se refere a articulação com os municípios que ainda estão se apropriando da metodologia, bem como criando condições estruturais nos equipamentos sociais ${ }^{86}$ para que a estratégia possa de fato ser implantada nos municípios.

\section{Fortalecimento do SUAS}

O fortalecimento do SUAS é uma importante estratégia para o Plano Rio Sem Miséria e deve consistir num esforço compartilhado, objetivando o fortalecimento da Política de Assistência Social.

Para que seja possível avançar o Plano Rio Sem Miséria, é necessário que as Gestões Municipais possa ter condições de efetuar as suas ações. Para isso é necessário que tenham uma estrutura adequada.

\footnotetext{
${ }^{86}$ Dentre as condições podemos citar: informatização, acesso a internet, ampliação do quadro de pessoal, dentre outras.
} 
Nesse sentido, em reunião realizada em conjunto pela SSASDG e pela SSIPS para apresentação da estratégia de acompanhamento familiar e de fortalecimento do SUAS, tive oportunidade de participar como observadora participantes e pude auferir alguns aspectos, conforme explanações dos gestores municipais, que apontam como os principais desafios:

- Ausência de equipamentos sociais em número e qualidade suficientes;

- Ausência de equipamentos sociais nas áreas mais vulneráveis;

- Localização dos equipamentos sociais em locais distantes das áreas mais vulneráveis;

- Deficiência de pessoal e de infraestrutura (informática, internet, mobiliário e material de expediente);

- Pouca preparação de equipes técnicas para lidar com o processo de implementação e execução do Plano Rio Sem Miséria;

- Ausência de capacitações;

- Ausência de condições estruturais para a realização das abordagens e acompanhamento ás famílias.

Podemos observar que são muitos os investimentos necessários para que de fato ocorra o fortalecimento do SUAS, no que se refere a investimentos que demandam recursos financeiros, mas especialmente no que se refere a vontade política dos Prefeitos Municipais, bem como no estado, do Governo do Estado.

É preciso compreender o papel e a importância da política de Assistência Social e da sua materialização, que é o SUAS, para que de fato as ações possam ser implementadas e, dentre elas o Plano Rio Sem Miséria.

Esta, é uma estratégia que está sendo implementadas por meio do cofinanciamento do Governo do Estado para os municípios, porém carece de ampliação para que inicialmente sejam disponibilizados equipamentos sociais em número suficiente. É preciso pensar ainda em ampliação de recursos humanos, bem como em estrutura e equipamentos, dentre tantas melhorias necessárias. 


\section{Articulação do Rio Sem Miséria com o Programa Bolsa Família e Cadastro Único}

A execução do Plano Rio Sem Miséria está amplamente ligada ao Programa Bolsa Família e o Cadastro Único, visto que é partir da plataforma do Governo Federal é que são realizadas as ações do Plano Estadual, no denominado federalismo social.

No federalismo social, as ações da esfera estadual e municipal levam em considerações as informações do Cadastro Único, bem como são direcionadas aos beneficiários do PBF.

A integração do Plano Rio Sem Miséria ao Cadastro Único e ao PBF será descrita a seguir, de acordo com as estratégias do Plano estadual.

\section{Programa Renda Melhor}

Para ter direito a receber o benefício do Programa Renda Melhor as famílias precisam ser beneficiárias do Programa Bolsa Família e, isto significa, consequentemente estar cadastrada no Cadastro Único.

As bases do Cadastro Único municipais também são utilizadas para a extração das informações das famílias a fim de efetuar o cálculo da renda estimada/presumida.

\footnotetext{
"O desenho do Programa Renda Melhor considera a multidimensionalidade e os determinantes estruturais da pobreza. Ao invés de selecionar as famílias beneficiárias com base apenas na renda declarada no Cadastro Único pelo Responsável Familiar, como é o caso do Programa Bolsa Família, o Programa Renda Melhor pondera um conjunto de informações constantes no Cadastro Único que refletem diversas dimensões da pobreza". (Ana Vieira, Superintendente de Renda de Cidadania)
}

O cruzamento das informações contidas no Cadastro Único é feito a partir de um modelo de estimação de renda desenhado pelo Centro de Políticas Sociais da Fundação Getúlio Vargas (CPS/FGV). Esse modelo estatístico utiliza essas informações contidas no Cadastro Único para compor uma equação, a qual gera como resultado um valor que estima/presume a renda da família. 
Com base da renda estimada/presumida das famílias é que serão identificadas as famílias que devem receber os benefícios do Programa Renda Melhor, bem como o valor a ser pago a cada família. ${ }^{87}$

É importante destacar que as famílias são consideradas na sua individualidade, com base nas suas condições específicas por meio das informações contidas no Cadastro Único para a definição do valor do benefício. Isso é muito importante, visto que são consideradas as condições pessoais de severidade de pobreza que assolam cada família especificamente.

Já a integração com o PBF refere-se também é preponderante para a definição do valor do benefício, visto que este é somando a renda para definir a renda presumida/estimada das famílias.

A situação do benefício da família no PBF também vai definir se a família receberá o valor do PRM no mês de competência ${ }^{88}$. Ou seja, a família somente o receberá se o benefício do PBF estiver na situação de liberado. Caso esteja na situação de bloqueado, suspenso ou cancelado, a famílias não receberá o PRM.

Anualmente, a relação dos beneficiários (folha raiz) do Programa Renda Melhor é revisada, em cumprimento à normativa legal (Art. $9^{\circ}$ da Lei $6.088 / 2011$,$) .$

A revisão anual da folha raiz foi regulamentada pela Resolução SEASDH $\mathrm{n}^{\text {o }} 567$ de 08/05/201, a qual regulamentou a periodicidade de sua execução a cada exercício, sempre ocorrendo no mês de junho de cada ano, bem como os critérios a serem adotados em relação às bases do Cadastro Único e da folha do PBF a serem utilizadas em cada apuração.

A revisão anual compreende a revisão dos valores dos benefícios das famílias já atendidas pelo programa, a inclusão de novas famílias identificadas em situação de extrema pobreza e a saída das famílias que deixaram de atender os critérios de exigibilidade do Programa.

As principais determinantes para as alterações na Folha Raiz do Renda Melhor:

\footnotetext{
${ }^{87}$ Aqui estamos nos referindo a Revisão Anual do Programa Renda Melhor.

${ }^{88}$ Mensalmente é efetuada a consulta no Cadastro Único e no PBF para a geração da folha de pagamento do Programa Renda Melhor.
} 
- Alterações na renda estimada das famílias (para mais ou para menos);

- Alterações no valor do Programa Bolsa Família (básico, variáveis e Benefício para Superação da Extrema Pobreza - BSP);

- Inclusão, atualização e/ou revisão cadastral por meio de ações de busca ativa no Estado.

Os principais motivos para a saída das famílias do Programa são os seguintes:

- As famílias que ultrapassarem a linha de pobreza extrema adotada pelo Governo do Estado do RJ (R\$ 100,00), devido:

- Aumento na renda estimada das famílias;

- Alteração no valor do benefício do Programa Bolsa Família (básico, variáveis e BSP);

- Famílias com o benefício do PBF bloqueado ou suspenso no mês de fevereiro, que é utilizado como referência para a revisão anual da folha raiz;

- Saída das famílias do Programa Bolsa Família (benefício cancelado).

Para a realização da revisão anual ${ }^{89}$ do Programa Renda Melhor serão consideradas:

- As informações constantes na base do Cadastro Único do mês de janeiro do exercício corrente;

- A folha de pagamento do Programa Bolsa Família do mês de fevereiro do exercício corrente.

\footnotetext{
${ }^{89}$ De acordo com o disposto no Artigo $9^{\circ}$ da Lei 6.088, anualmente os valores dos benefícios do Renda Melhor serão revisados, podendo sofrer alterações para mais ou para menos, de acordo com as modificações identificadas na renda familiar per capita estimada. Isso significa que a cada ano é gerada uma nova folha raiz, na qual ocorrem entradas e saídas de famílias, e também a permanência de famílias com o mesmo valor de benefício ou com aumento/redução do valor do benefício.
} 


\section{Programa Renda Melhor Jovem}

A articulação entre o PRMJ entre o PBF e o Cadastro Único é fundamental para a execução do Programa.

Somente serão beneficiários do Renda Melhor Jovem aqueles jovens cujas famílias forem beneficiárias do PBF e consequentemente estejam cadastradas no Cadastro Único.

As informações do Cadastro Único são utilizadas para a obtenção de informações com relação a escolaridade, bem como ao estabelecimento de educação dos alunos beneficiários. A partir destas informações é efetuada a busca ativa dos alunos pela SEEDUC.

\section{Gestão de Oportunidades Econômicas e Sociais}

O GOES tem como prioridade as ações com as famílias sem situação de extrema pobreza e os públicos do Cadastro Único e do PBF estão nesta situação.

Esta estratégia do PRSM preconiza que o conjunto de informações disponíveis no Cadastro Único devem ser utilizados para a realização de diagnósticos que permitam a oferta territorializada de oportunidades econômicas e sociais para as famílias em situação de vulnerabilidades sociais e riscos sociais e pessoais.

Essas informações são importantes para o planejamento e a expansão das ações, visando aproximação das ofertas e das demandas do território. A identificação de públicos com perfis específicos (extrema pobreza, trabalho infantil, comunidades tradicionais, catadores de material reciclável, beneficiários do BPC e pessoas em situação de rua), a partir da marcação de determinados campos no Cadastro Único, tem sido importante tanto para que acessem a transferência de renda por meio do PBF e do PRM, assim como direitos, serviços, outros benefícios e oportunidades econômicas e sociais.

Os dados fornecidos pelo Cadastro Único também são importantes para que seja possível a realização do planejamento e dimensionamento das ofertas 
para este público de acordo com as suas especificidades, bem como no território onde vivem.

Apesar da previsão destas ações para a estratégia do GOES, objetivando a utilização das informações do Cadastro Único para as ações, desde a implantação do Plano Rio Sem Miséria não foram realizadas ações especificas por meio da seleção de famílias do Cadastro Único.

As ações do GOES que tiveram prosseguimento foram aquelas direcionadas ao público do Renda Melhor Jovem , cujas famílias são beneficiárias do PBF e cadastradas no Cadastro Único, bem como nas ações do Pronatec-BSM que preconiza como beneficiárias as famílias do PBF e do Cadastro Único.

Por fim cabe destacar que não conseguimos obter os números referentes às famílias que foram atendidas por meio da integração entre o GOES e o PBF e Cadastro Único.

\section{Acompanhamento Familiar e Fortalecimento do SUAS}

Se de um lado os critérios objetivos estabelecidos pelo Rio Sem Miséria tem viabilizado o acesso a ampliação e a segurança de renda por meio do PRM e do PRMJ, por outro lado as orientações do SUAS e do Plano Estadual tem proporcionado a ampliação na rede estadual dos CRAS, CREAS e CREPOP, proporcionando assim o fortalecimento das ações der acompanhamento familiar.

As ações de busca ativa realizadas pelas equipes municipais com o apoio da Gestão Estadual, bem como pelas equipes de abordagem social da Proteção Social Especial tem contribuído para que o Plano Rio Sem Miséria alcance aquelas populações que vivem em contextos mais isolados ou em situações mais difíceis de acesso á Política de Assistência Social por busca espontânea ou por encaminhamento.

Cabe destacar que a estratégia de busca ativa, como um dos eixos do Plano Rio Sem Miséria tem possibilitado a identificação, cadastramento no Cadastro Único e acompanhamento das pessoas em caso de trabalho infantil e em situação de rua. Com identificação destas pessoas, além da segurança de renda, as mesmas são inseridas em programas específicos de acordo com as suas necessidades. 
Esta estratégia do Plano Rio Sem Miséria, integrada com o Cadastro Único e com o PBF tem contribuído tanto para a inclusão das famílias, como para o acesso de renda, por meio do PBF, BPC e PRM, quer seja pela sua vinculação aos serviços assistências, que recebe apoio para a sua ampliação por meio da estratégia de fortalecimento do SUAS, preconizada pelo PRSM.

As famílias Cadastro Único ${ }^{90}$ são o público preferencial das ações de acompanhamento familiar, assim como as famílias do PBF em situação de descumprimento de condicionalidades, situação esta que passa a ser reconhecida como indicador de vulnerabilidade social ou risco pessoal e social ${ }^{91}$.As famílias em situação de acompanhamento familiar, pode-se interromper os efeitos de descumprimento de condicionalidades, garantindo assim a continuidade e regularidade da transferência de renda. ${ }^{92}$

Cabe destacar ainda que as famílias beneficiárias do PBF, PRM e PRMJ são público prioritário do atendimento nos diversos serviços do SUAS, particularmente aquelas destinadas ao acompanhamento familiar. Nesse sentido vale registrar que não conseguimos obter as informações referente as ações de acompanhamento familiar das famílias do Plano Rio Sem Miséria, que são beneficiárias do PBF, bem como aquelas cadastradas no Cadastro Único.

Com relação a outra estratégia importante que é a busca ativa,que preconiza a inserção das famílias no Cadastro Único para serem beneficiárias de Programas Sociais como PRM e o PRMJ, podemos observar que o número famílias cadastradas vem sendo ampliado no Estado.

Outra ação importante desenvolvida pela Coordenação Estadual do Programa Bolsa Família e Cadastro Únicoe a Coordenação do PRM, em parceria com as Gestões Municipais são as ações de busca ativa para o cadastramento de grupos específicos

\footnotetext{
90 Informações disponibilizadas pelo Cadastro Único é que vão definir os públicos do acompanhamento familiar.

${ }^{91}$ De acordo com orientações da Intrução Operacional Conjunta SENARC/SNAS nº 19/2013.

92 Conforme preconiza o Protocolo de Gestão Integrada de Serviços e Beneficios de transferência de Renda ( Brasil, 2009).
} 


\section{Articulação PRSM com o Plano Brasil Sem Miséria}

O Plano Brasil Sem Miséria traz uma estratégia diferenciada ao buscar a redução da miséria articulando e potencializando políticas públicas existentes em associação com a criação de novas ações. Outra ação importante é a experiência do Plano com os planos estaduais destinados ás famílias que se encontravam em condições de pobreza extrema, como é o caso do Plano Rio Sem Miséria.

Com efeito, a implementação do Plano Brasil sem Miséria tem como foco o planejamento de ações com uma abordagem integrada e voltada para o caminho de desenvolvimento a ser trilhado em cada caso, vislumbrando-se o seu futuro como comunidades e pessoas autônomas e integradas territorialmente às localidades em que se situam.

No Estado do Rio de Janeiro a criação do Plano Rio Sem Miséria em consonância com o Plano Brasil Sem Miséria preconiza a construção de estratégias integradas entre ambos os planos.

Ocorre que conforme podemos detectar por meio da presente pesquisa não ocorre de fato a integração entre o Plano Brasil Sem Miséria e o PRSM de maneira expressiva, a exceção do Pronatec- BSM, do PBF e do Cadastro Único que são estratégias executadas de maneira compartilhada entre ambos os planos.

Com relação às demais estratégias do Plano Brasil Sem Miséria, não há acompanhamento especifico por parte da Coordenação Estadual do PRSM no que se refere ao desenvolvimento das suas ações no Estado.

Sabe-se que ações estão ocorrendo, porém não um setor especifico para realizar o acompanhamento das mesmas. Também não é possível identificar se o público do PRSM está sendo alvo das ações do PBSM, assim como não há acompanhamento do Plano Federal por parte da Gestão Estadual, ou seja, não há indicador demonstrando se as ações são integradas. 


\section{Articulação do Rio Sem Miséria com a política de Assistência Social}

A trajetória da implementação da Política de Assistência Social não deixa dúvidas que seu campo de atuação não se limita apenas à questão da pobreza, mas busca afiançar direitos e a inclusão social.

Para a Política de Assistência Social, a situação de pobreza, não é concebida como o sinônimo de ausência de renda mas como uma situação complexa e multidimensional, que exige uma intervenção multiseotrial, conforme preconiza o PRSM.

No que se refere à integração com a Política de Assistência Social, é importante destacar que os avanços do SUAS no estado do Rio de Janeiro nos últimos dez anos contribuíram para consolidar um modelo de proteção social específico para o Estado. Esse modelo tem como uma de suas premissas centrais a articulação do acesso á renda ao acompanhamento familiar pelos serviços sócio assistenciais, bem como o acesso a um conjunto de políticas públicas, o que vislumbra o enfrentamento das situações de pobreza na sua multidimensionalidade.

Podemos observar que a integração entre o Plano do Estado do Rio Janeiro e a política de Assistência Social tem ocorrido de maneira incisiva, tanto na esfera estadual como nas esferas municipais.

No estado do Rio de Janeiro, a articulação entre o PRMS e a Política de Assistência Social segue a mesma tendência do modelo nacional: a atenção integral a família não apenas para a redução da pobreza ou para a garantia dos mínimo sociais. Objetiva-se a redução dos riscos sociais e a ampliação das capacidades de proteção e enfrentamento das vulnerabilidades e riscos pelas famílias e indivíduos.

Na esfera estadual, a articulação e a integração entres as Subsecretarias, a de Assistência Social e Descentralização da Gestão, responsável pela condução da política de Assistência Social no Estado, e a Subsecretaria de Descentralização da Gestão, responsável pelo PRSM, ambas da SEASDH, tem avançado, no sentido de elaboração estratégias e ações conjuntas, bem como de pactuações conjuntas na CIB para o reforço dos compromissos do Plano, sob a ótica da assistência social, 
bem como da proteção social. Porém, ainda são necessários avanços no sentido de uma agenda conjunta de fato e do planejamento e execução de ações na esfera estadual e nos municípios, tendo como a integração do PRSM com a agenda da política de assistência social, que se configura na execução do Plano, fato. ${ }^{93}$

$\mathrm{Na}$ esfera municipal, onde de fato as políticas, programas e ações se materializam, pela proximidade com os beneficiários, apontamos avanços significativos no sentido da compreensão da necessidade da integração e da articulação do PRSM com a assistência social, especialmente no reforço dessa premissa, junto aos gestores, que tem o condão decisório do modus operandi da política nas suas localidades, observadas nas reuniões da CIB e nas agendas compartilhadas $^{94}$ que tem sido constantemente realizadas pelas Secretarias Municipais de Assistência Social.

O foco do Plano tem sido ajustado no sentido de, incialmente superar a extrema pobreza, por meio da transferência monetária. Nesse sentido, compreende-se que PRSM, por meio do PRM, que complementa PBF, presente na totalidade dos municípios fluminenses ${ }^{95}$, pelo volume de famílias e pessoas beneficiárias e de recursos aplicados, tem potencial para reduzir a extrema pobreza, no que se refere ao aspecto monetário, no Estado.

A busca ativa foi uma importante estratégia adotada para a ampliação da cobertura cadastral no estado do Rio de Janeiro. Em 12 meses, o número de famílias cadastradas no estado passou de 1.331.127 famílias para 1.508.226 famílias, representando um amplo crescimento e compromisso das gestões municipais com a estratégia e com o Plano.

O Plano indica que, vencida a etapa da cobertura plena de benefícios do PRM, deve constituir uma rede de serviços de proteção social e promoção social, para que os programas e serviços, ou seja as oportunidades econômicas e sociais previstas no GOES, sejam acessíveis, universalmente aos pobres e extremamente

\footnotetext{
${ }^{93}$ Observa-se a ausência da compreensão de que o PRSM e a política de assistência social estejam ligados umbilicalmente. Há indícios que tal fato esteja ligado a ausência da participação da equipe da Subsecretaria de Assistência Social e Descentralização Social na concepção e implementação do Plano. Esta informação foi convalidada durante as entrevistas.

${ }^{94}$ As Secretarias Municipais de Assistência Social estão fazendo um movimento de integração de Proteção Social Básica com o PRSM. Observa-se esse fato nas reuniões nos municípios e nas discussões a nível de CIB.

95 O município do Rio de Janeiro não está contemplado pelo Programa Renda Melhor, por possuir um programa próprio de transferência de renda, o Programa Cartão Família Carioca.
} 
pobres. Busca ainda, no interior do PBF alternativas para maximizar as estratégias do PRMJ e do GOES, junto aos mais pobres.

O Plano beneficia-se do fato do Estado ter atingido a cobertura plena do PBF, então investe esforços por meio do reforço ao SUAS e ao Acompanhamento Familiar para o aumento da cobertura dos serviços de proteção social. Essas estratégias estão em fase de implantação e consistem num dos grandes desafios para o Plano, pois apesar do apoio da Gestão Estadual aos municípios no que se refere a capacitações, suporte técnico, cofinancimento e elaboração de um Plano Estadual de Acompanhamento Familiar em 2012, com base nos critérios do Pacto de Aprimoramento da Gestão, é na esfera municipal que as famílias são localizadas, atendidas e acompanhadas.

Os fatores acima são consubstanciados pela assinatura do Termo de Adesão dos Municípios ao PRM e PRMJ, comprometendo-se assim também com as estratégias de acompanhamento familiar e ainda assim, percebe-se a ausência de reforço por parte das Gestões Municipais nestas ações. Os principais fatores identificados ${ }^{96}$ como causadores diretos da carência destas ações consistem em: número reduzido de equipamentos sociais ou ainda precariedade das instalações; falta de estrutura de informática e internet; equipe de pessoal reduzida; alta rotatividade dos servidores; ausência de concursos públicos na grande maioria dos municípios, o que impede a continuidade das atividades; falta de vontade política, bem como o estabelecimento destas ações como prioritárias por parte do Gestor Municipal da Assistência Social e; ausência de conhecimento técnico para a realização das atividades.

Percebe-se o desafio no acesso dos beneficiários do PBF e do PRM aos serviços da assistência social pelos fatores acima identificados, bem como pela demanda do CRAS e dos locais de atendimentos às famílias no que se refere à Assistência Social estar centralizada no atendimento às demandas no Cadastro

\footnotetext{
96 Aspectos identificados na Oficina Integrada sobre Acompanhamento Familiar, realizada pela Subsecretaria de Integração de Programas e Subsecretaria de Assistência Social e Descentralização da Gestão em 2013, com a presença dos 92 municípios do Estado (em duas etapas) e um dos questionamentos referia-se aos fatores causadores da carência das ações de busca ativa e acompanhamento familiar.
} 
Único e do próprio PBF e PRM, seja pela ausência de estrutura, seja pela sobrecarga que estas demandas acarretam. ${ }^{97}$

A articulação com o PBF permitiu ainda aos beneficiários do PRM que possuem as mesmas condicionalidades, reforços na garantia de direitos e acesso à aos serviços de saúde e educação. Observa-se porém, que as famílias têm acessados os serviços de saúde e educação para o cumprimento das condicionalidades, mais por receio das sanções nos benefícios (bloqueio, suspensão e cancelamento, nessa ordem), do que pela mobilização para cumprimento ou da consciência do acesso ao serviço como um direito assegurado pela Constituição Federal.

É compreendido por todos, nas esferas municipais e na esfera estadual, a necessidade e a importância da articulação do Plano com a política de Assistência Social, também em ambas as esferas para que o PRSM consiga atingir seus objetivos com plenitude.

Dessa forma, o Plano pode ir além da meta de erradicação da pobreza monetária, articulando as dimensões de bem-estar a partir da construção de uma estratégia plena e sustentável, fundadas em direitos e garantias sociais para todos os cidadãos do estado do Rio de Janeiro.

Porém para que isso ocorra é necessária a compreensão de que a proteção social não é responsabilidade precípua da política de Assistência Social, mas deve abarcar um conjunto de estratégias construídas intersetorialmente com outras políticas, com foco na superação da pobreza multidimensional, conforme preconiza o Plano.

\section{Plano Rio Sem Miséria: fatores facilitadores da sua implantação e gestão para a redução da pobreza}

Entre os aspectos facilitadores, considerados como positivos por ocasião do estudo de caso junto à Coordenação Estadual do PRMJ, que contribuem para a redução da pobreza no Estado do Rio de Janeiro, os seguintes merecem destaque:

\footnotetext{
${ }^{97}$ Estes fatores foram identificados no diálogo com o Gestores e técnicos municipais.
} 
- Ampla cobertura de famílias extremamente pobres alcançadas pelo Programa Renda Melhor (as famílias identificadas no Cadastro Único e PBF na situação extremamente pobres foram plenamente atingidas pelo PRM);

- Pagamento dos benefícios do PRM às famílias por meio de cartão compartilhado com o PBF, evitando assim deslocamentos desnecessários para as famílias;

- Fortalemcimento da figura da mulher com a manutenção do recebimento do benefício do PRM no nome da mulher a exemplo do que ocorre com o PBF;

- Ampliação do orçamento familiar;

- Liberdade da família para a aplicação dos recursos do PRM;

- Adoção da concepção de família como unidade de atendimento a exemplo da LOAS, PNAS, PBF e Cadastro Único, superando a visão fragmentada e isolada de membros de família;

- Utilização da plataforma do governo federal, o novo federalismo social, unificando assim os programas sociais, evitando desta maneira a fragmentação e a superposição de programas sociais;

- Descentralização da gestão do PRSM para as gestões municipais;

- Respeito ao pacto federativo por meio da assinatura do termo de adesão;

- Respeito a autonomia da gestão municipais para o desenvolvimento das ações na esfera municipal;

- Utilização do conceito de renda presumida/estimada;

- Transferência de benefício monetários ás famílias e por meio de cartão bancário, no caso do PRM e PRMJ, diminuindo as possibilidades de clientelismo;

- Estratégias compostas pela integração entre benefícios monetários e serviços sócio assistenciais, potencializando a intersetorializada e a 
possibilidade do desenvolvimento da ampliação de oportunidades e capacidades das famílias;

- Importância da utilização do Cadastro Único, permitindo a focalização e eliminando a duplicidade se articulado a outros sistemas;

- Sistemas de consulta das informações para as gestões municipais, no caso do PRM;

- Canais de comunicação para os gestores municipais com a Coordenação Estadual, no caso do PRM e PRMJ;

- Canal de comunicação para atendimento das demandas da famílias, no caso do PRM (a Ouvidoria, da SEASDH);

- Interesse das Gestões Municipais em executar as estratégias do PRSM;

- Previsão de estratégias compartilhadas e intersetoriais com os demais órgãos e Secretarias do Estado;

- Ampliação do cofinanciamento do Estado para o financiamento dos equipamentos sociais, embora não tenha sido possível quantificar os recursos;

- Elaboração da estratégia de Acompanhamento Familiar;

- Ações de busca ativa realizadas em conjunto com as Gestões Municipais;

- Amplas capacitações realizadas pela Coordenação Estadual junto as Gestões Municipais sobre o Plano;

- Estratégia do PRMJ como fortalecimento ao capital humano: investimento em educação;

- Autonomia dos jovens para desembolsarem o valor do recursos do RMJ da maneira que julgarem necessário;

- $\quad$ Articulação com o Pronatec-BSM;

- Ampliação da cobertura cadastral no Estado;

- Ampliação do número de famílias beneficiárias no Estado; 
- Ampla parceria com a CIB, Coegemas e CEAS

\section{Desafios para o Plano Rio Sem Miséria}

Entre os desafios, considerados aqui pontos negativos do processo de implementação e gestão do PRSM são elencados os seguintes aspectos:

- O Plano é visto como um plano da SEASDH e não é apreendido como um Plano do Estado;

- Gestão do Plano centrada na SSIPS e não no Governo do Estado;

- Assinatura de Adesão apenas do PRM e não ao PRMJ;

- Atribuições ás Gestões Municipais apenas estabelecidas para o PRM;

- Não estabelecimento formal das atribuições da Gestão Estadual em algumas estratégias do Plano, como por exemplo o GOES;

- Infraestrutura parca no estado para a execução do Plano (veículos, telefone, etc.);

- Reduzido quadro de pessoal no Estado para a execução do Plano;

- Deficiência de infraestrutura para o desenvolvimento do Plano nos municípios;

- Insuficiência de quadro de pessoal nas gestões municipais para o desenvolvimento das ações do Plano;

- Uso da classificação das famílias pobres e extremamente pobres;

- Adoção de valor mínimo baixo para o pagamento do RM;

- Adoção de valores não relacionados ao salário mínimo para pagamento do RM;

- Não reajusto do RM e do RMJ desde o início do Programa;

- Penalização das famílias que estão inseridas no mercado de trabalho, no caso da renda autodeclarada;

- Focalização do programa; 
- Não consideração do histórico de pobreza das famílias, considerando apenas a situação atual;

- Ausência de financiamento das Gestões Municipais para as ações do Plano;

- Ausência de financiamento da Gestão Estadual para a execução do Plano;

- Deficiência qualitativa e quantitativa da rede sócio assistencial nos municípios para operacionalização do Plano;

- Realização de capacitações para as demais estratégias do Plano, para além do PRM e do Acompanhamento Familiar;

- Maior articulação com o Banco do Brasil para o atendimento dos beneficiários do PRMJ;

- Falta de articulação com os parceiros para o mapeamento das ofertas de oportunidades econômicas;

- Falta de estrutura para o mapeamento das demandas das famílias objetivando a sua inserção no GOES;

- Falta de continuidade nas ações, especialmente da Gestões Municipais por ocasião das mudanças de gestão;

- Falta de articulação para o encaminhamento dos beneficiários para os programas de qualificação profissional, com por exemplo o PronatecBSM;

- Ausência de articulação com os serviços da Assistência Social;

- Ausência de articulação com o Plano Brasil Sem Miséria;

- Ausência de articulação com outra políticas e serviços de outras políticas;

- Dificuldade de diálogo dos beneficiários com as Gestões Municipais que muitas vezes não tem condições de prestar informações sobre o PRSM; 
- Alta rotatividade das equipes das Gestões Municipais, com a consequente perda das informações adquiridas por meio de capacitações pela equipe anterior ou pelos servidores anteriores;

- Problemas no Cadastro Único: desatualização cadastral e inconsistência de informações;

- Informações erradas prestadas pelas famílias por ocasião do cadastramento e não corrigidas pelas Gestões Municipais que não tem condições de realizar visitas domiciliares para averiguar as informações declaradas pelas famílias. As gestões municipais não possuem recursos físicos e financeiros para a realização das visitas;

- Dificuldades de acesso às famílias, especialmente aquelas que residem em locais de difícil acesso;

- Ausência de conhecimento sobre o Plano pelas famílias;

- Demora no atendimento das demandas dos jovens do PRMJ;

- Demora para o pagamento dos jovens do PRMJ;

- Os prazos, em geral definidos pelo MDS têm sido insuficientes para atender ás solicitações, principalmente aquelas mais complexas, implantado no PRM;

- Ausência de ações de gestão de benefícios nos municípios, o que acaba prejudicando o recebimento do benefício do PRM e PRMJ;

- Ausência de mutirões de cadastramento mais regulares nos municípios;

- Morosidade na entrega dos cartões para as famílias;

- Ausência de documentação para cadastramento das famílias nos municípios;

- Ausência de documentação para a abertura de contas pelos jovens no Banco do Brasil;

- Limitada capacidade financeira dos municípios, especialmente os de pequeno porte para o investimento em atendimento e divulgação do Plano para as famílias; 
- Sobrecarga de trabalho dos profissionais das Assistência Social que possuem uma séria de atribuições para além do Plano;

- Ausência de conhecimento sobre o Plano por parte dos profissionais das Gestões Municipais;

- Pouca articulação entre as Gestões Federal, Estadual e municipais;

- Ausência de articulação com a sociedade civil;

- Pouca articulação com a rede privada;

- Baixa articulação entre as diversas secretarias e órgãos do Governo do Estado;

- Desconsideração das especificidades regionais e municipais para na implementação do Plano;

- Ausência de discussão com as Gestões Municipais para a elaboração do Plano;

- Pouca discussão com as demais secretarias e órgãos do Estado para a elaboração do Plano;

- Não elaboração de instrumentos informativos para os beneficiários do Plano;

- Dificuldades na concretização de um trabalho com as famílias beneficiárias no tocante ao desenvolvimento de ações sócio educativas;

- Nenhum contato com as famílias beneficiarias;

- Poucas ações com relação ao desenvolvimento de estratégias para a capacitação de famílias beneficiárias;

- Baixo desempenho do Pronatec;

- Demora para chegar informações sobre o Plano, bem como pouca busca de informações por parte da Gestões Municipais, mesmo com acesso a internet;

- Ausência de promoção de eventos para as famílias beneficiárias; 
- Pouca articulação entre as Secretarias Municipais para o desenvolvimento de ações compartilhadas;

- Falta de bom senso de alguns políticos ao repassar para as famílias beneficiárias que é o prefeito ou governador responsável pelo PRSM, estabelecendo um campo fértil para o clientelismo;

- O GOES é uma estratégia que não foi implementada de fato; 


\section{6 \\ Conclusão}

A previsão de uma vida digna para todos os seres humanos constitui preceito central da Carta de Promulgação dos Direitos Humanos ${ }^{98}$ pela ONU há mais de sessenta anos atrás. Entretanto, na atualidade esse direito ainda não foi efetivado para uma parcela significante da população mundial. O tema da pobreza é uma dos mais centrais no contexto da globalização, no qual a riqueza, a tecnologia e o conhecimento chegam a níveis altíssimos de avanços, porém uma ampla parcela da população mundial permanece sem acessá-los, representando desta maneira que também estão longe de alcançar os direitos humanos básicos, bem como o piso mínimo para viver com dignidade, ainda que tais padrões sejam relativos e discutíveis.

A pobreza acompanha a humanidade há século e apesar de toda a riqueza gerada, pessoas em grande quantidade morrem de fome e da falta de acesso à água potável, já outras não sabem ler, não tem acesso à saúde, vivem sem liberdade e de forma indigna e sub humana. Tais constatações estão presentes no nosso cotidiano, porém as mesmas não são sem importância. De acordo com Vera Telles (1999), acostumamo-nos com a pobreza, vista e sentida, como paisagem, algo que não nos incomoda, quando muito se torna problema quando ameaça a ordem e a segurança nacional.

A vida digna não é apenas um direito, mas um direito fundamental, por isso a sua conexão com a pobreza. Outro fator relevante é que a construção do problema da pobreza e sua consequente categorização de um grupo como pobres ou excluídos, demanda do ponto de vista societário e moral, bem como uma decisão de governo, uma tomada de posição e o desenvolvimento de ações de enfrentamento a pobreza e por conseguinte, de inclusão e integração social.

$\mathrm{Na}$ parte das considerações finais cabe ressaltar alguns pontos, sem pretender reconstruir toda a trajetória desenvolvida no trabalho, mas apenas

\footnotetext{
98 A Declaração Universal dos Direitos Humanos, que delineia os direitos humanos básicos, foi adotada pela Organização das Nações Unidas em 10 de dezembro de 1948.
} 
enfatizar questões que merecem destaque, a partir da análise de literatura e do estudo empírico realizado.

Sintetizando e articulando o conjunto de categorias e concepções identificadas buscou-se no trabalho salientar distintas concepções sobre a pobreza, procurando trazer um conjunto de aspectos pertinentes aos enfoques de pobreza para que fosse possível realizar uma análise posterior se determinada política tem potencial para contribuir com a redução da pobreza. Cada um dos enfoques examinados - monetário, necessidades básicas e capacidades - nos aponta que a concepção de pobreza é multidimensional, heterogênea e com aspectos relacionais em sua produção e manutenção, exigindo dessa maneira, para o seu enfrentamento uma ação pública baseada em políticas intersetoriais e territoriais, com serviços flexíveis de acordo com a necessidades heterogêneas das populações nos territórios, com redes de serviços adequadas ao atendimento e, quanto ao seu conteúdo, orientadas para a autonomia e empoderamento do público atendido, com vista a expansão das oportunidades e escolhas e adoção de estratégias mais efetivas para o enfrentamento das condições de pobreza, principalmente aquela é imensa no tempo e extensa na profundidade das privações e interação perversa entre os seus vetores.

As famílias e pessoas em situação de pobreza e extrema pobreza padecem de uma síndrome de privações e aspectos de carências, mas também apresentam ativos que podem ser mobilizados desde que o suporte efetivo ocorra, bem como seja articulado, por parte das estruturas e processos, produzidos por meio das políticas públicas. A adoção de formas mais flexíveis de e relacionais de gestão pública local, aderentes ás necessidades das pessoas, famílias, grupos e territórios e desenvolvidas pelos diversos setores das políticas e níveis de governo de forma mais integradas constituem estratégias potencialmente mais exitosas, segundo as concepções mais exitosas de políticas.

Tendo como base a premissa de que a pobreza e a desigualdade no Brasil seriam combatidas paulatinamente com o avanço do progresso e do desenvolvimento econômico, o tema, apesar de não estar ausente das preocupações e reflexões do país sobre o seu futuro, conforme observou Telles (2001), era visto como elemento quase imutável, permanente e tinha caráter secundário, não merecendo tratamento específico. 
Além disso, a pobreza e a desigualdade não eram relacionadas com os padrões de formação e organização da sociedade brasileira, extremamente hierarquizada e com concentração de renda. De acordo com Jaccoub (2010), não eram temas abordados como violência ou negação de direitos ou negação de dignidade, mas sim como consequências naturais da formação da sociedade mediante o processo econômico e este mesmo processo daria conta de resolvê-las.

Percebemos, especialmente após a promulgação da Constituição Federal de 1988, a alteração deste quadro, quando a lei maior do país passa a prever no art. 23, inciso $X$, a competência dos entes federados para combater as causas da pobreza e os fatores de marginalização promovendo a integração social dos setores desfavorecidos. Conjuntamente, cresceu também no Brasil, nos anos de 1990, os estudos sobre a temática e a preocupação na elaboração da agenda das políticas públicas, destacando-se como prioridade o combate à pobreza e as desigualdades sociais.

Em 2003, com a criação do Programa Bolsa Família- PBF, focalizado nos pobres e extremamente pobres e, pela intervenção diretamente no campo da renda, destaca-se o debate público e os inúmeros estudos sobre o Programa, com distintas leituras sobre sua configuração, seu futuro e seu papel, assim como a preocupação na sua gestão e execução pelo Governo Federal e pelos governos municipais, que mantém uma relação direta quando se trata do PBF.

Em 2011, sob o governo da Presidente Dilma é criado o Plano Brasil Sem Miséria- PBSM com o objetivo audacioso de erradicar a pobreza extrema no Brasil até 2014, cujas frentes de atuação devem ser realizadas de forma integrada por um conjunto de Ministérios, secretarias e órgãos do governo federal e consistem em: elevar a renda familiar per capita das famílias beneficiárias que se encontram em situação de extrema pobreza; ampliar o acesso dos mais pobres aos serviços públicos, as ações de cidadania e bem estar social e; a execução de medidas que visam ampliar o acesso a oportunidades de ocupação e renda por meio de ações de inclusão produtiva nos meios urbano e rural. Além de integrar ações já existentes, com outras elaboradas especificamente em seu âmbito, o Plano tem como uma de suas diretrizes centrais o estabelecimento de parcerias com os governos estaduais e municipais, com entidades da sociedade civil e empresas. 
Alinhado a estratégia do Governo Federal, o governo do Estado do Rio de Janeiro implementou o Plano Rio Sem Miséria, que consiste no Plano Estadual de Superação da Pobreza, composto pelo Programa Renda Melhor, Programa Renda Melhor Jovem (PRMJ), Gestão de Oportunidades Econômicas e Sociais e a estratégia de Fortalecimento do Sistema Único de Assistência Social e o Acompanhamento Familiar.

A presente pesquisa teve como objetivo realizar um estudo de casa sobre o Plano Rio Sem Miséria e, após este procedimento empírico, construir uma cadeia de evidências que permitam concluir que o Plano, pode contribuir para a redução doa pobreza no estado do Rio de Janeiro, assim como elencar os desafios e as perspectivas futuras para o Plano.

Partimos da premissa de que a desigualdade é característica marcante no Estado, que apesar de possuir o $2^{\circ}$ maior PIB e a $3^{\circ}$ maior renda per capita do país entre as unidades da federação, é o $17^{\circ}$ em desigualdade de renda, com mais de 586 mil pessoas vivendo em situação de extrema pobreza. Percebe-se que o desenvolvimento econômico, os grandes investimentos que na última década foram realizados no Estado e a perspectiva de investimentos e retornos financeiros com os megaeventos ${ }^{99}$ não garantiram o acesso a distribuição da riqueza gerada de forma igualitária a população.

Sem a pretensão de esgotar o tema, a reflexão desenvolvida tem como objetivo a análise e caraterização do Plano Rio Sem Miséria e sua implementação e gestão no estado do Rio de Janeiro, analisando se mesma tem potencial para a redução da pobreza da pobreza na esfera local. Para responder este questionamento central, é necessário pontuarmos alguns pontos que podem ser considerados fundamentais, divididos em potencialidades e desafios para o PRSM.

Em termos de potencialidades podemos citar:

- Entendemos que o PRSM, articulado com o PBF, presente na totalidade dos municípios fluminenses ${ }^{100}$, pelo volume de famílias e pessoas beneficiárias e de recursos aplicados, tem potencial para

${ }^{99}$ Cidade-sede da Copa do Mundo em 2014 e sede das Olimpíadas em 2016.

${ }^{100}$ O município do Rio de Janeiro não está contemplado pelo Programa Renda Melhor, por possuir um programa próprio de transferência de renda, o Programa Cartão Família Carioca. 
contribuir com a redução da desigualdade da pobreza no Estado do Rio de Janeiro;

- É uma experiência que tem logrado êxito no que se refere ao novo modelo de políticas públicas adotados no Brasil: o novo federalismo social, em que o governo subnacional atua de maneira integrada sobre a plataforma do Cadastro Único e do PBF, complementando ações e inovando em ações executadas nos programas, evitando assim sobreposição e pulverização das ações;

- Outro aspecto relevante é a utilização do conceito de renda estimada, em que não se utiliza a informação da renda monetária declarada pelas famílias, mas sim um conjunto de informações contidas no Cadastro Único, em que é possível capturar a situação individual das famílias, colocando-a na centralidade para que a mesma receba o benefício de acordo com a sua situação não apenas de insuficiência de renda, mas de desigualdade a qual é submetida;

- A articulação com o PBF e com a política de Assistência Social permitiu aos beneficiários do Programa Renda Melhor- PRM que possuem as mesmas condicionalidades, reforços na garantia de direitos e acesso aos serviços de saúde, educação e assistência social;

- O PRM é uma estratégia que foi amplamente implantada e se encontra em processo pleno de execução e regularidade. Apresenta fluxo operacional, sistemas informacionais, manuais e guias, ações de capacitação e acompanhamento aos municípios, bem como um conjunto de ações de monitoramento e acompanhamento;

- O Programa Renda Melhor Jovem oferece a oportunidade e incentivo para os adolescentes e jovens ingressarem, permanecerem e concluírem o ensino médio, por meio de prêmios e assim elevar o índice de jovens concluintes do ensino médio, das famílias extremamente pobres. Este fato implica na redução de desigualdade entre os mais pobres, por meio do acesso à educação;

- A busca ativa foi uma importante estratégia adotada para a ampliação da cobertura cadastral no estado do Rio de Janeiro. Em 12 meses, o 
número de famílias cadastradas no estado passou de 1.331.127 famílias para 1.508.226 famílias, representando um amplo crescimento e compromisso das gestões municipais com estratégia e com o Plano.

Como desafios futuros para o Plano, entendemos que sejam:

- $\quad$ atendimento a todas as famílias em situação de extrema pobreza ainda é um desafio, ou seja, é necessário que todo o público alvo do Plano seja alcançado em todas as estratégias para que a universalização seja plenamente atingida. Como exemplo, citamos o PRMJ, quando observamos na pesquisa, que nem todos os jovens com perfil de elegibilidade para o Programa estão inseridos, por problemas operacionais;

- A focalização precisa ser compreendida como progressiva, tendo em vista a se atingir a universalização relativa ao público definido pelos critérios de elegibilidade do Plano;

- Para cumprir os fins a que se propõe, o Plano deve ampliar a cobertura não apenas para as famílias em situação de extrema pobreza, mas para aquelas famílias pobres e que conviveram com uma longa história de pobreza. A renda estimada é um avanço, mas é necessário ampliar o recorte de renda;

- A Gestão de Oportunidades Econômicas e Sociais (GOES) ainda é uma estratégia que carece de ampliação, ou seja, as oportunidades ofertadas para as famílias são limitadas, descontínuas e insuficientes, tanto no que se refere à qualificação profissional, como para os encaminhamentos ao mercado de trabalho, além dos limites do próprio mercado de trabalho, que é incapaz de absorver toda a população apta;

- A responsabilidade pela execução do Plano nos municípios é responsabilidade da política de assistência social. Não houve uma discussão para a construção e o planejamento de uma agenda coletiva com os Gestores Municipais. Em função deste fato, acorrem algumas situações em que o funcionamento do Plano não é compreendido e apreendido pelas Gestões Municipais; 
- A ausência de articulação entre os diversos segmentos públicos e privados envolvidos na gestão do Plano, reforça a necessidade da construção de uma agenda conjunta de fato, evitando ações replicadas nos mesmos territórios em detrimento a não execução de ações em territórios com elementos de extrema vulnerabilidade;

- Centralidade no quadro de pessoal nos municípios, onde, de fato, o Plano é executado, visto que há atendimento direto ás famílias. Identificamos a insuficiência quantitativa, a instabilidade e a capacitação deficiente para o desenvolvimento de trabalhos requeridos pela alta complexidade, em grande número devido pela rotatividade dos servidores;

- O fortalecimento do SUAS ainda é um grande desafio para a política de assistência social. Em função da grande demanda incorporada e atrelada a esta, número de equipamentos sociais e sua estrutura física e de pessoal está longe de atender as demandas e as necessidades da população que necessita de atendimento;

- O acompanhamento familiar ainda é uma agenda que precisa ser priorizando tanto pela Gestão Estadual como pela Gestão Municipal do PBF e do PRSM, objetivando o acompanhamento das famílias em situação de vulnerabilidade;

- A criação e o fortalecimento de uma rede na esfera estadual, municipal e com a sociedade civil constituem-se um dos principais desafios para que PRSM consiga alcançar os seus objetivos de maneira eficiente e eficaz.

- A necessidade da adesão dos municípios ao Plano Rio Sem Miséria e não apenas ao PRM;

- Alteração dos fluxos e procedimentos do PRMJ, objetivando o amplo acesso dos beneficiários elegíveis ao Programa;

Retomando as concepções de pobreza adotadas neste tendo como referência entendemos que o PRSM tem potencial para auxiliar na redução da pobreza, especialmente no que se refere à pobreza monetária e a satisfação das 
necessidades básicas, que tem cunho monetário. Com relação à privação de capacidades, o GOES, se implementado de acordo com as suas diretrizes, bem como com a premissa do acesso universal a população em situação de extrema pobreza, tem potencial para contribuir com a construção de condições que visem à dignidade para estas pessoas. Já a pobreza crônica somente poderá ser enfrentada por meio de mudanças estruturais em vários aspectos: políticos, econômicos, sociais e culturais.

Com a consolidação de parte das estratégias que compõem o Plano (PRM e PRMJ) pela focalização, é necessário, no entanto, o fortalecimento das demais estratégias e a expansão das políticas protetivas, para a inclusão destas famílias em um sistema de proteção mais amplo e integrado, capaz de lidar com o que hoje, visivelmente não consegue: com os riscos e com as incertezas.

O Estado tem a função precípua de provedor das políticas públicas com a finalidade do enfrentamento da questão social, no sentido de criar mecanismos para a diminuição dos impactos das relações fragilizadas no âmbito do trabalho que origina indivíduos com vulnerabilidades sociais oriundas da relação de exploração advinda do sistema capitalista, que é cerne da questão social.

O Plano Rio Sem Miséria é uma estratégia recente, com muitos avanços aqui registrados, e na atual conjuntura social e econômica do Estado do Rio de Janeiro pode ser considerado necessário pelas estratégias que possui para a redução da pobreza e, mais ainda, pelo potencial que possui para ampliar estes efeitos.

Experiências como a do estado do Rio de Janeiro, são exemplos de iniciativas locais de inclusão social e são fundamentais para viabilizar a proximidade entre as demandas e os problemas de para aumentar a chance de respostas mais adequadas a elas. Entretanto, uma atuação estratégica para o enfrentamento da pobreza exige um conjunto de ações que envolve o poder público federal, estadual e municipal em articulação entre si e com o a esfera privada e a sociedade civil, bem como outros segmentos que se encontram fora a esfera das políticas públicas.

Sem essas ações estaremos realizando o mesmo trabalho de Sísifo, que levava a pedra ao alto da montanha para vê-la cair novamente. É preciso inserir a 
questão da pobreza multidimensional com ação intersetorial no centro das políticas públicas e não apenas das políticas sociais ou ainda, com maior brevidade de inserção, apenas como responsabilidade da política de Assistência Social.

As ações para a redução da pobreza fazem parte de um conjunto relacionado a própria dignidade humana, sem utopia, como um objetivo a ser perseguido de maneira contínua, sem tréguas, para assim construir novas possibilidades e oportunidades humanas.

O caminho para essa utopia é longo e talvez, o final não seja alcançável. Mas construir conhecimento e ações mais efetivas no campo das políticas públicas não é uma escolha, mas sim uma questão ética e instrumental.

A razão de ser do presente trabalho traz consigo, acima de qualquer aspecto o reforço ao enfrentamento da pobreza, mas além disso a elaboração de políticas públicas que busquem acima de tudo a preservação dos direitos humanos e da dignidade dos seres humanos, por meio do desenvolvimento de política públicas adequadas. 


\section{7 \\ Referências Bibliográficas}

ABRAHAMSON, P. Neoliberalismo, pluralismo de bem-estar e configuração das políticas sociais. Política Social. Brasília, v. 2, p.109-134, 2004. (Política Social: Alternativas ao Neoliberalismo).

ADELMAN, M. Visões da Pós-modernidade: discursos e perspectivas teóricas. Sociologias [online]. 2009, n.21, p. 184-217. ISSN 1517-4522.

ALVES-MAZZOTTI, A. J. Usos e abusos dos estudos de caso. Cadernos de Pesquisa, v.36, n.129, p. 637-651, 2006.

ANANIAS, P. A economia, o trabalho e as políticas sociais. Disponível em:<http://www.mds.gov.br>. Acesso em: 10 set. 2014.

Mercosul social e o "caminho das esperanças". Disponível em:<http://www.mds.gov.br>. Acesso em: 10 set. 2014.

O caminho da emancipação social. Disponível em:<http://www.mds.gov.br>. Acesso em: 10 set. 2014.

Políticas permanentes. Disponível em:<http://www.mds.gov.br $>$. Acesso em: 10 set. 2014.

. Crise e políticas sociais. Disponível em:〈http://www.mds.gov.br>. Acesso em: 10 set. 2014.

em:<http://www.mds.gov.br>. Acesso em: 10 set. 2014.

O Brasil, de baixo para cima. Disponível Política social: O que temos a falar; o que temos a aprender. Disponível em:<http://www.mds.gov.br>. Acesso em: 10 set. 2014.

As portas de entrada. Disponível em: $\langle\mathrm{http}: / / \mathrm{www} \cdot \mathrm{mds}$.gov.br $\rangle$. Acesso em: 10 set. 2014. 
ANANIAS, P. As portas de saída. Disponível em:<http://www.mds.gov.br>. Acesso em: 10 set. 2014.

Pobres e o projeto nacional. Disponível em: $\langle$ http://www.mds.gov.br $>$. Acesso em: 10 set. 2014.

_. Os mais pobres entre os pobres. Disponível em:<http://www.mds.gov.br>. Acesso em: 10 set. 2014.

A dignidade do trabalho. Disponível em: $<$ http://www.mds.gov.br $>$. Acesso em: 10 set. 2014.

Rede de proteção social. Disponível em: $<$ http://www.mds.gov.br $>$. Acesso em: 10 set. 2014.

Políticas sociais como pilar fundamental para o desenvolvimento de uma nação. Disponível em:<http://www.mds.gov.br〉. Acesso em: 10 set. 2014.

_. As condições para ensinar a pescar. Disponível em: <http://www.mds.gov.br >. Acesso em: 10 set. 2014.

A eficácia das políticas de transferência de renda. Disponível em:<http://www.mds.gov.br>. Acesso em: 10 set. 2014.

Economia solidária. Disponível em: $\langle$ http://www.mds.gov.br $>$. Acesso em: 10 set. 2014.

_. Ver as árvores e enxergar o bosque. Disponível em:<http://www.mds.gov.br>. Acesso em: 10 set. 2014.

Estado nacional. Disponível em: $\langle$ http://www.mds.gov.br $>$ Acesso em: 10 set. 2014.

_. Empresa e responsabilidade social. Disponível em:<http://www.mds.gov.br>. Acesso em: 10 set. 2014.

Estado e justiça social. Disponível em: $<$ http://www.mds.gov.br $>$. Acesso em: 10 set. 2014.

em:<http://www.mds.gov.br>. Acesso em: 10 set. 2014. 
ANANIAS, P. Constituição Cidadã, 20 anos. Disponível em:<http://www.mds.gov.br>. Acesso em: 10 set. 2014.

O fortalecimento de um novo modelo de política social. Disponível em:<http://www.mds.gov.br $>$. Acesso em: 10 set. 2014.

A política social e a resposta à globalização. Disponível em:<http://www.mds.gov.br>. Acesso em: 10 set. 2014.

_. Transferir renda e superar a pobreza. Disponível em:<http://www.mds.gov.br>. Acesso em: 10 set. 2014.

. Bolsa Família - um elo forte da rede. Disponível em:<http://www.mds.gov.br >. Acesso em: 10 set. 2014.

. Os pobres não podem pagar a conta. Disponível em:<http://www.mds.gov.br>. Acesso em: 10 set. 2014.

Qualificação - desenvolvimento com justiça social. Disponível em:<http://www.mds.gov.br>. Acesso em: 10 set. 2014.

- Parcerias para desenvolvimento. Disponível em:<http://www.mds.gov.br>. Acesso em: 10 set. 2014.

ANDERSON, P. Balanço do neoliberalismo. In: SADER, E. (Org.). Pósneoliberalsimo: as políticas sociais e o Estado Democrático. Rio de Janeiro: Editora Paz e Terra, 1995.

ÁRIAS, A. R.; THEODORO, M. Cenários de emprego e renda no Brasil até 2000. In: Para a década de 90: prioridades e perspectivas nas políticas públicas, v.3. Brasília. IPEA/Iplan, março de 1990.

BAHIA, L. H. N. O Poder do Clientelismo: raízes e fundamentos da teoria política. Rio de Janeiro: Renovar, 2003.

BANCO MUNDIAL. O trabalho e o processo de integração mundial. Washington, DC: BIRD, 1995.

BARBALET, J. M. A cidadania. Lisboa: Estampa, 1989. In: BOBBIO, N. A era dos direitos. Rio de Janeiro: Campus, 1992. 
BARBOSA, A. de F. O Brasil Real: a desigualdade para além de indicadores. São Paulo: Outras Impressões, 2012.

BARROS, R. P. de; HNRIQUES, R.; MENDONÇA, Rosane. A estabilidade Inaceitável: desigualdade e pobreza no Brasil. Rio de Janeiro, IPEA, n.800, 2000 .

BATTINI, O. (Org). SUAS: Sistema Único de Assistência Social em Debate. Curitiba: Veras, 2007.

BEHRING, E. R. Brasil em contra- reforma: desconstrução do Estado e perda dos direitos. São Paulo: Cortez, 2003.

Política social no capitalismo tardio. São Paulo, Cortez, 1998.

BEVERIDGE, W. O Plano Beveridge: relatório sobre o Seguro Social e serviços afins. Rio de Janeiro: José Olympio, 1943.

BODSTEIN, R. C. de A. Cidadania e modernidade: emergência da questão social na agenda pública. Cadernos de Saúde Pública [online]. 1997, v.13, n.2, p. 185-193. ISSN 0102-311X.

BÓGUS, L. et.al., (Org.). Desigualdade e Questão Social. $3^{\text {a }}$ Ed. São Paulo: EDUCA, 2011.

BOSCHETTI, I. Assistência Social no Brasil: um direito entre originalidade e conservadorismo. $2^{\mathrm{a}}$ edição. Brasília, 2003ª .

Do dever moral de ajuda ao dever legal de assistência. Cadernos de Texto de Serviço Social. Belém. Unama, v.4, n.5, out.1998b.

Assistência Social e os Programas de Transferência de Renda. Evento: CICLO DE DEBATES DO MINISTÉRIO DE ASSISTÊNCIA SOCIAL, realizado em 21 de outubro de 2003, mimeo, Brasília, 2003d.

Saídas para a crise: o debate teórico em torno do programa de renda mínima. In: Aldaíza S. (Org.). Renda mínima e crise mundial: saída ou agravamento? São Paulo: Cortez, 1997.

BOSCHETTI, I.; Salvador, E. Orçamento da Seguridade Social e Política Econômica. Perversa alqumia, Brasil.mimeo, 2006. 
BRASIL. Bolsa Família: formatura em qualificação profissional no Rio de Janeiro terá participação do presidente Lula e do ministro Patrus Ananias. Ministério do Desenvolvimento Social e Combate à Fome. Disponível em: <http://www.mds.gov.br>. Acesso: 16 set. 2014.

Constituição (1988). Constituição da República Federativa do Brasil, 1988. Brasília: Senado Federal, Centro Gráfico, 1988. 292 p.

Desenvolvimento Social e Combate à Fome: Balanços e Desafios. Ministério do Desenvolvimento Social e Combate à Fome - MDS. Brasilia: SAGI, 2010.

Programa Bolsa Família: uma década de inclusão e cidadania. Ministério do Desenvolvimento Social e Combate à Fome - MDS. Brasilia: IPEA, 2014.

Relatório Final da $1^{\text {a }}$ Conferência Mundial sobre o Desenvolvimento de Sistemas Universais de Seguridade Social. Ministério da Saúde. Brasilia: MS, 2012.

CAMPOS, A. et al. (Orgs.). Atlas da exclusão social no Brasil: dinâmica e manifestação territorial. São Paulo: Cortez, 2003.

CARNEIRO, C. B. L. Concepções sobre pobreza e alguns desafios para intervenção social. Revista Serviço Social e Sociedade. n. 84. Ed Cortez. Novembro, 2005.

CARVALHO, F. C. de. O retorno de Keynes. Novos estudos - CEBRAP [online]. 2009, n.83, p. 91-101. ISSN 0101-3300.

CARVAlHO, J. M. de. Cidadania no Brasil. O longo caminho. Rio de Janeiro: Civilização Brasileira, 2007.

CASTEL, R. As metamorfoses da questão social: uma crônica do salário. Petrópolis: Vozes, 1998.

CASTRO, J. A. et al. (Orgs.). Bolsa Família 2003-2010: Avanços e Desafios. v.1 e v.2. Brasília: IPEA, 2010.

CECEÑA, A. E. (Org.). Hegemonias e Emancipações no Século XXI. Buenos Aires: CLACSO, 2005. 
CEPAL. Dados sobre pobreza na américa latina. Disponível em: <http://www.cepal.org/brasil/>. Acesso em: 15 dez. 2014.

CEPERJ. Anuário RJ 2013. Dipsonivel em: <http//www.ceperj.gov.br>. Acesso em: 10 dez. 2014.

CERQUEIRA FILHO, G. A “questão social” no Brasil: crítica do discurso político. Rio de Janeiro: Civilização Brasileira, 1982.

COBO, B. Políticas Focalizadas de Transferência de Renda: Contextos e Desafios. São Paulo: Cortez, 2012.

COLIN, D. R. A. et. al. (Org.). 20 Anos da Lei Orgânica da Assistência Social: Coletânea de Textos 2013. Brasilia: MDS, 2013.

CORTEZ, R. P. S. Globalização e proteção social nos países desenvolvidos: uma análise da literatura. Rev. Sociol. Polit. [online]. 2008, v.16, n.31, p. 161-176. ISSN 0104-4478.

COUTO, B. R. O Direito Social e a Assistênca Social na Sociedade Brasileira: uma equação possível? São Paulo: Cortez, 2010.

COUTO, B. R. et. al. (Org.). O Sistema Único de Assistência Social no Brasil: uma realidade em movimento. $3^{\mathrm{a}}$ Ed. São Paulo: Cortez, 2012.

DAGNINO E. R. et al. Metodologia de análise de políticas públicas. In: Gestão estratégica da inovação: metodologia para análise e implementação. Taubaté, Editora Cabral Universitária. 2002. Disponível em <http://www.campusoel.orgsalactisi/rdagnino1.htm>.

DRUCK, G.; FILGUEIRAS, L. Política social focalizada e ajuste fiscal: as duas faces do governo Lula. Rev. katálysis [online]. 2007, v.10, n.1, p. 24-34. ISSN $1414-4980$.

ESPING-ANDERSEN, G. As três economias políticas do Welfare State. Lua Nova, n. 24, São Paulo: CEDEC, 1991.

FAGNANI, E. Política social e pactos conservadores no Brasil: Economia e Sociedade. Campinas, n.13, 1999.

FALEIROS, V. de P. O trabalho da Política. São Paulo: Cortez, 1992. 
FALEIROS, V. de P. A política social do estado capitalista: as funções da previdência e assistência sociais. 7ed. São Paulo: Cortez, 1995.

FARIA, C. A. P. Idéias, conhecimento e políticas públicas: um inventário sucinto das principais vertentes analíticas recentes. Revista Brasileira de Ciências Sociais, v.18, n. 51, p. 21-30, fev. 2003.

FERNANDES, F. Sociedades de Classe e Subdesenvolvimento. São Paulo: Global, 2008.

FONSECA, A.; VIANA, A. L. Tensões e Avanços na Descentralização de Políticas Sociais: o caso do Programa Bolsa Família. In: FLEURY, S. Democracia, Descentralização e Desenvolvimento: Brasil \& Espanha. São Paulo: FGV, 2006. p.443-480.

FREI, B. (Org.) Fome Zero: Textos Fundamentais. Rio de Janeiro: Garamond, 2004

FREITAS, R. de C. Martinelli. O governo Lula e a proteção social no Brasil: desafios e perspectivas. Revista Katálysis, v.10, n.1, 2007. p. 65-74.

FREY, K. Políticas públicas: um debate conceitual e reflexões referentes à prática da análise de políticas públicas no Brasil. Planejamento e Políticas Públicas, Brasília, IPEA n. 21, Jun. 2000. p. 212-258.

GENTILLI, P. (Org.). Globalização Excludente: desigualdade, exclusão e democracia na nova ordem mundial. Petropolis: Vozes, 2008.

GOHN, M. da G. Teorias dos Movimentos Sociais: paradigmas clássicos e contemporâneos. São Paulo: Loyola, 1997.

HENRIQUES, R. Desigualdade racial no Brasil: evolução das condições de vida na década de 90. Texto para discussão, n.807.IPEA, jul. 2001.

HOFLING, H. M. Estado e Políticas (públicas) sociais. Cadernos CEDES. Ano XXI, n. 55, nov. 2001. p. 30-41.

IAMAMOTO, M. V. A Questão social no capitalismo. Temporalis - Revista da Associação Brasileira de Ensino e Pesquisa em Serviço Social - ABEPSS. Ano II, $\mathrm{n}^{\mathbf{o}} 3$ - janeiro a junho de 2001. 
KERSTENETZKY, C. L. Políticas Sociais: focalização ou universalidade? Revista Economia Política [online]. 2006, v.26, n.4, p. 564-574. ISSN 01013157.

LAVINAS, L.; VARSANO, R. Renda mínima: integrar e universalizar. Novos Estudos Cebrap, São Paulo, n. 49, nov. 1997.

LÜDKE, M. ANDRÉ, M. E. D. A Pesquisa em educação - abordagens qualitativas. São Paulo: Editora Pedagógica e Universitária, 1986.

MARSHALL, T. H. Cidadania, classe social e status. Rio de Janeiro: Zahar Editores, 1967.

MOLINA, C. G. Modelo de formación de políticas y programas sociales: notas de clase. Banco Interamericano de Desarrollo, Instituto Interamericano para el Desarrollo Social. Diseño y gerencia de politicas y programas sociales, 2002. $<$ http://indes.iadb.org/verpub.asp?dl=1\&docNum=6203>. Acesso em: 30 set. 2014.

MOTTA, A. E. (Org.). Desenvolvimentismo e Construção de Hegemonia: Crescimento Econômico e Reprodução da Desigualdades. São Paulo: Cortez, 2012.

O Mito da Assistência Social: ensaios sobre Estado, Política e Sociedade. $4^{\text {a }}$ Ed. São Paulo: Cortez, 2010.

NETTO, J. P. Desafios para a Política Social no combate à pobreza. Seminário 20 anos do NEPPOS - Núcleo de Estudos e Pesquisas em Política Social, da UnB. Palestra proferida em 19/10/2007.

OLIVEIRA, H. M. J. de. Cultura Política e Assistência Social: uma análise das orientações de gestores estaduais. São Paulo: Cortez, 2003.

OSZLAK, O.; O`DONNEL, G. Estado y políticas estatales en la América Latina: hacia una estrategia de investigación, Buenos Aires, CEDES/G.E., Clacso, 1976.

PAES, N. L.; SIQUEIRA, M. L. Renda básica da cidadania versus imposto de renda negativo: o papel dos custos de focalização. Estud. Econ. [online]. 2008, v.38, n.3, p. 583-610. ISSN 0101-4161. 
PASTORINI, A. A Categoria Questão Social em Debate. São Paulo, Ed. Cortez, 2004.

PELÁEZ, F. J. C. Derechos sociales: teoría e ideología. Madrid: Tecnos, 1994.

PEREIRA PEREIRA, P. A. Pluralismo de bem-estar ou configuração plural da política social sob o Neoliberalismo. Política Social. Brasília, n. 2, p.135160, 2004.

Necessidades Humanas - subsídios à crítica dos mínimos sociais. $3^{\mathrm{a}}$ ed. São Paulo: Ed. Cortez, 2006.

Política Social - temas \& questões. São Paulo: Ed. Cortez, 2008a.

Discussões conceituais sobre política social como política pública e direito de cidadania. In: BOSQUETTI, I., BEHRING, E. SANTOS, S., MIOTO, R. (Orgs.). Políticas Sociais no capitalismo - tendências contemporâneas. São Paulo: Ed. Cortez, 2008b.

PEREIRA PEREIRA, $P$. et al. Polêmica entre direita e esquerda sobre necessidades, políticas e direitos sociais: um confronto das idéias de Friedrich von Hayek e Raymond Plant. Revista Textos \& Contextos. Porto Alegre, v. 8, n.1, p. 49-67. Jan. a Jun. 2009.

POCHMANN, M. O Emprego no Desenvolvimento da Nação. São Paulo: Boitempo, 2008.

POLANYI, K. A grande transformação: as origens da nossa época. $2^{\mathrm{a}}$ edição. Rio de Janeiro: Elsevier, 2000.

POSTONE, M. Teorizando o mundo contemporâneo: Robert Brenner; Giovanni Arrighi; David Harvey. Novos estud. - CEBRAP [online]. 2008, n.81, p. 79-97. ISSN 0101-3300.

POUlAnTZAS, N. O Estado, o Poder, o Socialismo. 2.ed. Rio de Janeiro: Graal, 1985.

REGO, W. L. et al. Vozes do Bolsa Família: Autonomia, dinheiro e cidadania. São Paulo: UNESP, 2013. 
REIS, E.; SCHWARTZMAN, S. Pobreza e Exclusão Social: aspectos sociopolíticos. Versão Preliminar, World Bank, 2002. Disponível em: <http://www.schwartzman.org.br>. Acesso em: 04 dez. 2014.

ROCHA, S. Pobreza no Brasil. Afinal, de que se trata? $3^{\mathrm{a}}$ Ed. Rio de Janeiro: FGV, 2006.

ROSAVALLON, P. A nova questão social: repensando o estado providência. Tradução: Sérgio Bath. Brasília. Instituto Teotônio Vilela, 1998.

SAlAMA, P. et. al., O Tamanho da Pobreza: Economia Politica da Distribuição de Renda. Rio de Janeiro: Garamond, 2001.

SANTOS, B. S. Reinventar a democracia. Lisboa: Gradiva, Fundação Mario Soares, 1998.

SEASDH. Manual do Programa Renda Melhor. 2014 (mimeo).

SEN, A. Desenvolvimento como Liberdade. São Paulo: Companhia das Letras, 2000 .

SILVA, M. O. S. et.al. (Org.). Políticas Públicas de Trabalho e Renda no Brasil Contemporâneo. São Paulo: Cortez, 2012.

(Org.). O Bolsa Família no Enfrentamento á Pobreza no Maranhão e no Piaui. São Paulo: Cortez, 2013. (Org.). Avaliando o Bolsa Família: unificação, focalização e impactos. São Paulo: Cortez, 2010.

SIMÕES, C. Teoria \& Crítica dos Direitos Sociais: O Estado Social e o Estado Democrático de Direito. São Paulo: Cortez, 2013.

SINGER, P. A América Latina na crise mundial. Estud. av. [online]. 2009, v.23, n.66, p. 91-102. ISSN 0103-4014.

SIQUEIRA, L. Pobreza e Serviço Social: diferentes concepções e compromissos políticos. São Paulo: Cortez, 2013. 
SOARES, F. V.; RIBAS, R. P.; OSÓRIO, R. G. Avaliando o Impacto do Programa Bolsa Família: uma Comparação com Programas de Transferência Condicionada de Renda de Outros Países. Evaluation Note. International Poverty Centre, Brasília, 2007.

SOARES, J. “Questão Social": Particularidade no Brasil. São Paulo: Cortez, 2012.

SOUZA, J. A Construção Social da Subcidadania. Belo Horizonte: Editora UFMG, 2012. In: SPOSATI, A. (Org.) Os Direitos dos (Desassistidos) Sociais. $7^{\mathrm{a}}$ Ed. São Paulo: Cortez, 2012.

SPOSATI, A. A Menina LOAS: um processo de construção da Assistência Social. 6a Ed. São Paulo: Cortez, 2011.

. (Org.). Assistência na Trajetória das Politicas Sociais Brasileiras.

$11^{\mathrm{a}}$ Ed. São Paulo: Cortez, 2010.

. (Org.). Proteção Social e Cidadania: Inclusão de Idosos e Pessoas

com Deficiência no Brasil, França e Portugal. São Paulo: Cortez, 2011.

SPOSATI, A. et al, (Org.). Assistência na Trajetória das Políticas Sociais Brasileiras. 12 ${ }^{\mathrm{a}}$ Ed. São Paulo: Cortez, 2014.

TANEZINI, T. C. Z. Parâmetros teóricos e metodológicos para análise de políticas sociais. Revista Ser Social, Brasília, n 14, p. 13-44, Jan. a Jun. 2004.

TELES, J. Educação e Políticas Públicas: Para além das metas do milênio. Revista Sinais Sociais, v.1, n.02, Set. a Dez. 2006.

THE ECONOMIST. Pobreza na América Latina Novo Pensamento sobre um Problema Antigo. 16 set. 2005. Disponível em: <http://www.mds.gov.br>. Acesso em: 10 set. 2014.

UNESCO. Concepção e Gestão da Proteção Social não Contributiva no Brasil. Brasília: Unesco, 2009.

Politicas Sociais para o Desenvolvimento: Superar a Pobreza e Promover o Desenvolvimento. Brasilia: UNESCO, 2010. 
WACQUANT, L. As prisões da miséria. Tradução André Telles. Rio de Janeiro: Jorge Zahar Ed.2001.

YASBEK, M. C. Classes Subalternas e Assistência Social. $7^{\text {a }}$ Ed. São Paulo: Cortez, 2009.

YIN, R. K. Case study research: design and methods. London: Sage,1984.

ZIEGLER, J. Destruição em Massa: Geopolítica da Fome. Trad. Jospe Paulo Netto. São Paulo: Cortez, 2013. 


\section{8 \\ Anexos}

8.1.

Anexo 1

DECRETO N 42.949 DE 10 DE MAIO DE 2011

INSTITUI, NO ÂMBITO DO ESTADO DO

RIO DE JANEIRO, O PROGRAMA

RENDA MELHOR, E DÁ OUTRAS PROVIDÊNCIAS.

GOVERNADOR DO ESTADO DO RIO DE JANEIRO, no uso de suas atribuições constitucionais e legais e tendo em vista o que consta do Processo $\mathrm{n}^{\circ}$ E-23/832/2011,

\section{CONSIDERANDO:}

- apesar dos avanços na promoção do desenvolvimento econômico e social, os índices de desigualdade no Estado do Rio de Janeiro permanecem inalterados nas últimas décadas;

- o combate às causas da pobreza e aos fatores de marginalização, e a promoção da integração social dos setores desfavorecidos são competências comuns às três esferas de Governo, conforme disposto no Art. 23 da Constituição da República Federativa do Brasil;

- o dinamismo econômico do Estado do Rio de Janeiro, impulsionado pelos grandes projetos de investimentos e pelos eventos esportivos internacionais a serem realizados no âmbito do Estado, representa uma oportunidade singular para um desenvolvimento econômico-social sustentável e inclusivo; 
- o Programa BOLSA FAMÍLIA, implantado pelo Governo Federal desde 2003, vem apresentando resultados importantes para a diminuição da pobreza e da desigualdade no Brasil, sem, contudo garantir a retirada de todas as famílias beneficiárias da situação de pobreza extrema;

\section{DECRETA:}

Art. $1^{\circ}$ - Fica instituído, no âmbito do Estado do Rio de Janeiro, o Programa RENDA MELHOR. Parágrafo Único - O Programa RENDA MELHOR consiste em um programa de transferência de renda às famílias que vivem em situação de extrema pobreza com o objetivo de proporcionar as condições básicas para uma vida digna.

Art. $2^{\circ}$ - O Programa RENDA MELHOR tem como premissas: I - A necessária integração das ações das três esferas de Governo para a promoção do desenvolvimento social, e II - A pobreza é um fenômeno complexo que abrange diversas dimensões para além da renda, que limitam as possibilidades de vida dos indivíduos e das famílias, e sua capacidade de se inserir no processo de desenvolvimento da sociedade.

Art. $3^{\circ}$ - Para fins deste Decreto adotam- se as seguintes definiçõos:

I - família: a unidade nuclear composta por um ou mais indivíduos, eventualmente ampliada por outros indivíduos que contribuam para o rendimento ou tenham suas despesas atendidas por aquela unidade familiar, todos moradores em um mesmo domicílio;

II - domicílio: o local que serve de moradia à família;

III - renda familiar mensal per capita: renda estimada a partir da apli

cação de algoritmo preditor de renda considerando informações do CADÚNICO e benefícios recebidos por meio do Programa Bolsa Família;

IV - pobreza extrema: renda familiar mensal per capita estimada abaixo de $\mathrm{R} \$ 100,00$ (cem reais), e

V - Hiato de Pobreza Extrema: Diferença entre a linha de pobreza extrema e a renda familiar per capita estimada. 
Art. $4^{\text {o }}$ - Serão beneficiários do Programa RENDA MELHOR as famílias atendidas pelo PROGRAMA BOLSA FAMÍLIA que se encontrem em situação de pobreza extrema, de acordo com as defini- ções deste Decreto. Parágrafo Único A renda familiar per capita será estimada a partir das informações registradas no Cadastro Único dos Programas Sociais do Governo Federal - CADÚNICO e dos benefícios pagos pelo Programa Bolsa Família.

Art. $5^{\circ}$ - Os Benefícios do programa serão calculados para cada família de forma a eliminar o hiato de pobreza extrema.

$\S 1 .^{\circ}-\mathrm{O}$ valor mínimo do benefício será $\mathrm{R} \$ 30,00$ (trinta reais) e o valor máximo será $\mathrm{R} \$ 300,00$ (trezentos reais) por família.

$\S 2 .^{\circ}$ - Os valores dos benefícios de a cada família do Programa RENDA MELHOR serão fixos até a geração de uma nova folha de pagamento, independente de flutuações ocorridas nos benefícios do Programa Bolsa Família nesse intervalo.

Art. $6^{\circ}$ Os benefícios serão pagos mensalmente, por intermédio do agente operador do Programa Bolsa Família.

I - o benefício será pago às famílias por meio de cartão magnético próprio do Programa RENDA MELHOR, com a identificação de seu responsável legal;

II - o titular do cartão será, preferencialmente a mulher ou, na sua ausência ou impedimento, outro responsável pela unidade familiar,

e III - o cartão de pagamento será de uso pessoal e intransferível e sua apresentação será obrigatória em todos os atos relativos ao Programa RENDA MELHOR.

Parágrafo Único - O titular do cartão do Programa RENDA MELHOR será o responsável pela família conforme definido no Cadúnico. 
Art. $7^{\circ}-$ As famílias atendidas pelo Programa RENDA MELHOR permanecerão com os benefícios liberados, mensalmente, para pagamento, salvo na ocorrência das seguintes situações:

I - descumprimento de responsabilidades e condicionalidades do Programa RENDA MELHOR, que acarrete bloqueio, suspensão ou cancelamento dos benefícios concedidos;

II - suspensão ou cancelamento dos benefícios do Programa Bolsa Família;

III - comprovação de fraude ou prestação deliberada de informações incorretas, quando do cadastramento ou atualização cadastral;

IV - desligamento por ato voluntário do beneficiário ou por determinação judicial, $\mathrm{e}$

V - alteração cadastral na família, cuja modificação implique a inadequação ao Programa.

$\S 1 .^{\circ}$ - No caso de normalização do cumprimento das condicionalidades do Programa, o pagamento do benefício será automaticamente restabelecido, sem direito a benefício retroativo.

$\S 2 .^{\circ}$ - Será desligada do Programa, pelo prazo de dois anos, ou definitivamente, se reincidente, a família cujo responsável prestar declaração falsa ou usar de qualquer outro meio ilícito e ou fraudulento para a obtenção de vantagens.

$3^{\circ}$ - Os benefícios, não sacados ou não recebidos por noventa dias, serão restituídos ao Programa RENDA MELHOR, conforme disposto em contrato com o Agente Operador.

Art. $8^{\circ}-\mathrm{O}$ Programa RENDA MELHOR seguirá as mesmas condicionalidades exigidas pelo Programa BOLSA FAMÍLIA.

Art. $9^{\circ}$ - As famílias beneficiárias do Programa RENDA MELHOR serão priorizadas no acompanhamento familiar desenvolvido no âmbito da política de assistência social e nas ações de gestão de oportunidades econômicas e sociais a serem coordenadas pelo Governo do Estado do Rio de Janeiro.

Art. 10 - O Estado deverá firmar com os Municípios Termo de Adesão ao Programa RENDA MELHOR. Parágrafo Único O Termo de Adesão estabelecerá as responsabilidades de cada ente na implementação do programa. 
Art. 11 - A Secretaria de Estado de Assistência Social e Direitos Humanos SEASDH estabelecerá os instrumentos normativos complementares para a implementação do Programa Renda Melhor.

Art. 12 - O Programa RENDA MELHOR será implementado em caráter piloto no ano de 2011 nos Municípios de Japeri, Belford Roxo e São Gonçalo.

Parágrafo Único - Ajustes poderão ser feitos a partir da avaliação dos resultados observados a partir da implantação do piloto.

Art. 13 - A expansão do Programa RENDA MELHOR a outros Municípios do Estado do Rio de Janeiro, além dos referidos no Art. 12 deste Decreto, dependerá de ato autorizativo do Governador, de acordo com as disponibilidades orçamentárias.

Art. 14 - As despesas decorrentes da execução deste Decreto correrão por conta de dotações orçamentárias próprias.

Art. 15 - Este Decreto entra em vigor na data de sua publicação.

Rio de Janeiro, 10 de maio de 2011

SÉRGIO CABRAL 


\section{2.}

\section{Anexo 2}

DECRETO No 42.963 DE 11 DE MAIO DE 2011

DÁ NOVA REDAÇÃO AO ART. $6^{\circ}$ DO DECRETO N ${ }^{\circ}$ 42.949, DE 10 DE MAIO DE 2011.

O GOVERNADOR DO ESTADO DO RIO DE JANEIRO, no uso das suas atribuições constitucionais e legais, e

CONSIDERANDO a conveniência de se unificar em único cartão de pagamento os valores referentes aos programas Bolsa Família e Renda Melhor

\section{DECRETA:}

Art. $1^{\circ}-\mathrm{O}$ art. $6^{\circ}$ do Decreto $\mathrm{n}^{\circ} 42.949$, de 10 de maio de 2011 passa a ter a seguinte redação:

“Art. $6^{\circ}$ - Os benefícios serão pagos mensalmente, por intermédio do agente operador do Programa Bolsa Família.

I - o benefício será pago às famílias por meio de cartão magnético especialmente confeccionado para esse fim, o qual englobará os valores pagos a título de "Bolsa Família" e "Renda Melhor" e conterá as logomarcas de ambos os programas;

II - as regras de concessão e uso do cartão magnético serão as mesmas definidas no programa Bolsa Família."

Art. $2^{\circ}$ - Ficam revogados o inciso III e o Parágrafo Único do art. $6^{\circ}$ do Decreto ${ }^{\circ}$ 42.949, de 10 de maio de 2011.

Art. $3^{\circ}$ - Este Decreto entra em vigor na data da sua publicação.

Rio de Janeiro, 11 de maio de 2011 


\section{3.}

\section{Anexo 3}

DECRETO Nº 42.999 DE 02 DE JUNHO DE 2011

INSTITUI NO ÂMBITO DO ESTADO DO RIO DE JANEIRO, O PROGRAMA RENDA MELHOR JOVEM E DÁ OUTRAS PROVIDÊNCIAS

O GOVERNADOR DO ESTADO DO RIO DE JANEIRO, no uso de suas atribuições constitucionais e legais,

\section{CONSIDERANDO:}

- a instituição do Programa RENDA MELHOR, por intermédio do Decreto $\mathrm{N}^{\mathrm{o}} 42.949$ de 10 de maio de 2011;

- as taxas de abandono e reprovação do ensino médio no Estado do Rio de Janeiro;

- o desempenho do Estado do Rio de Janeiro com relação ao Índice de Desenvolvimento da Educação Básica (Ideb);

- a necessidade de promover a inclusão social e econômica dos jovens em situação de pobreza extrema, vulnerabilidade e risco social.

\section{DECRETA:}

Art. $1^{\circ}$ - Fica instituído, no âmbito do Estado do Rio de Janeiro, o Programa RENDA MELHOR JOVEM.

Art. $2^{\circ}$ - O Programa tem como objetivos:

I - contribuir para a superação da pobreza extrema no Estado do Rio de Janeiro, levando em consideração os aspectos multidimensionais que a compõe;

II - incentivar os jovens beneficiários a se manterem no sistema educacional e a concluírem o Ensino Médio;

II - aumentar a taxa de conclusão do Ensino Médio;

III - reduzir os índices de vulnerabilidade econômica e social dos jovens; I

$\mathrm{V}$ - reduzir os índices de criminalidade entre os jovens. 
Art. $3^{\circ}-$ Os beneficiários do Programa RENDA MELHOR JOVEM deverão ser integrantes de famílias cadastradas no CADÚnico.

Parágrafo Único O Jovem interessado em ingressar no Programa deverá providenciar o cadastro de sua família no CADÚnico.

Art. $4^{\circ}-$ Os beneficiários do Programa RENDA MELHOR JOVEM serão preferencialmente aqueles integrantes de famílias atendidas pelo Programa RENDA MELHOR ou definidos por outras estratégias prioritárias de inclusão social do Governo do Rio de Janeiro, além de atender aos seguintes requisitos:

I - possuírem idade mínima de 15 anos e não superior a 17 anos completos no ano da adesão ao Programa;

II - estarem matriculados no Ensino Médio em instituição regular de ensino;

Art. $5^{\circ}$ - A Participação do beneficiário no Programa RENDA MELHOR JOVEM estará sujeita a aceitação de todos os termos previstos no regulamento através da assinatura do Termo de Adesão ao Programa.

Art. $6^{\circ}$ - O Programa RENDA MELHOR JOVEM concederá Prêmio de Aprovação para cada ano concluído com aprovação no Ensino Médio, definido conforme os seguintes critérios:

I - R \$ 700,00 (setecentos reais) após a confirmação de aprovação na $1^{\mathrm{a}}$ série do Ensino Médio;

II - R\$ 900,00 (novecentos reais) após a confirmação de aprovação na $2^{\mathrm{a}}$ série do Ensino Médio;

III - R \$ 1.000,00 (mil reais) após a confirmação de aprovação na $3^{\mathrm{a}}$ série do Ensino Médio.

$\S 1^{\circ}$ - No caso do Jovem estar cursando Ensino Técnico de 04 (quatro) anos, o Prêmio de Aprovação após a confirmação de aprovação será de R 900,00 (novecentos reais);

$\S 2^{\circ}$ - Serão considerados, para fins de cálculo dos Prêmios concedidos, somente os anos concluídos com aprovação após a entrada do jovem no Programa RENDA MELHOR JOVEM.

$\S 3^{\circ}-\mathrm{O}$ valor máximo concedido por meio do Prêmio de Aprovação não poderá exceder a $\mathrm{R} \$ 2.600,00$ (dois mil e seiscentos reais) para os alunos de 
cursos de 3 (três) anos e $\mathrm{R} \$ 3.500,00$ (três mil e quinhentos reais) para aqueles em cursos de 4 (quatro) anos.

Art. $7^{\circ}$ - Adicionalmente aos critérios indicados no artigo $5^{\circ}$ e parágrafos, o jovem deverá preencher, cumulativamente, as condições abaixo enumeradas para ser considerado apto a receber o Prêmio de Aprovação:

I - participar, pelo menos, de 03 (três) avaliações bimestrais promovidas pela Seeduc, denominadas Saerjinho.

II - alcançar aproveitamento mínimo de 60\% (sessenta por cento) na avaliação anual promovida pela Secretaria de Estado de Educação - SEEDUC, denominada Saerj.

Art. $8^{\circ}$ - Ao jovem concluinte do Ensino Médio que tenha obtido o Prê- mio de Aprovação nas três séries será concedida uma vaga em, pelo menos, 01 (um) curso técnico dentre os oferecidos pelos Centros de Vocação Tecnológica (CVT).

Art. $9^{\circ}$ - Será concedido um Prêmio de Conclusão Qualificada de R \$ 500,00 (quinhentos reais) aos jovens que, além de concluírem o Ensino Médio, submeterem- se ao Exame Nacional do Ensino Médio e obtiverem desempenho satisfatório. Parágrafo Único - Será considerado satisfatório resultado igual ou superior à nota definida em regulamento estabelecido conjuntamente entre a SEASDH e a SEEDUC.

Art. 10 - Os Prêmios instituídos por este Decreto serão depositados anualmente em conta do tipo Poupança, ou outro instrumento financeiro equivalente, aberta em nome do jovem. Parágrafo Único - Será facultado ao jovem beneficiado realizar saque no valor correspondente até $30 \%$ (trinta por cento) do valor depositado em cada ano.

Art. 11 - Os jovens atendidos perderão o direito aos benefícios, ainda não concedidos, caso seja verificada quaisquer das condições descritas a seguir:

I - reprovação por infrequência em qualquer série do Ensino Médio;

II - apresentar conduta incompatível com o regulamento do programa RENDA MELHOR JOVEM; 
III - comprovação de fraude ou prestação deliberada de informações incorretas, quando do cadastramento ou atualização cadastral;

IV - desligamento por ato voluntário do beneficiário ou por determinação judicial;

V - alteração cadastral do jovem, cuja modificação implique a inadequação ao Programa;

VI - atinja a idade de 20 anos completos;

VII - o jovem que desligar- se voluntariamente ou por determinação judicial do Ensino Médio, em qualquer tempo, terá acesso, apenas, ao valor de 30\% do Prêmio de Aprovação da(s) série(s) efetivamente concluída. PARÁGRAFO ÚNICO - No caso de normalização do cumprimento das condicionalidades do Programa, o pagamento do benefício será automaticamente restabelecido, sem direito a benefício retroativo.

Art. 12 - A Secretaria de Estado de Assistência Social e Direitos Humanos - SEASDH será a responsável pela coordenação das ações do RENDA MELHOR JOVEM, que deverão ser implementadas de forma articulada com a Secretaria Estadual de Educação - SEEDUC e demais entidades públicas federais, estaduais, municipais e da sociedade civil.

Art. 13 - Os Prêmios do Programa RENDA MELHOR JOVEM são de natureza pessoal e intransferível.

Art. 14 - A SEEDUC encaminhará anualmente à SEASDH a relação de beneficiários aptos a receberem os benefícios.

Art. 15 - A SEASDH elaborará a folha de pagamentos a partir das informações provenientes da SEEDUC.

Art. 16 - A SEASDH promoverá o acesso dos jovens beneficiários a atividades complementares voltadas à inclusão social e acesso a oportunidades para o seu pleno desenvolvimento. 
Art. 17 - A SEASDH e a SEEDUC estabelecerão em atos conjuntos os instrumentos normativos complementares para a implementação do Programa RENDA MELHOR JOVEM.

Art. 18 - O Programa RENDA MELHOR JOVEM será implementado em caráter piloto no ano de 2011 nos municípios de Japeri, Belford Roxo e São Gonçalo.

Art. 19 - A expansão do Programa RENDA MELHOR JOVEM a outros Municípios do Estado do Rio de Janeiro, além dos referidos no Art. 18 deste Decreto, dependerá de ato autorizativo do Governador, de acordo com as disponibilidades orçamentárias.

Art. 20 - As despesas decorrentes da execução deste Decreto correrão por conta de dotações orçamentárias próprias.

Art. 21 - Este Decreto entra em vigor na data de sua publicação.

Rio de Janeiro, 02 de junho de 2011

SÉRGIO CABRAL 


\section{4.}

\section{Anexo 4}

LEI Nº 6.088 DE 25 DE NOVEMBRO DE 2011

CRIA OS PROGRAMAS RENDA MELHOR E RENDA MELHOR JOVEM, NO ÂMBITO DO PLANO DE SUPERAÇÃO DA POBREZA EXTREMADO ESTADO DO RIO DE JANEIRO RIO SEM MISÉRIA - , E DÁ OUTRAS PROVIDÊNCIAS. O GOVERNADOR DO ESTADO DO RIO DE JANEIRO

Faço saber que a Assembléia Legislativa do Estado do Rio de Janeiro decreta e eu sanciono a seguinte Lei:

\section{CAPÍTULO I}

\section{DO PLANO RIO SEM MISÉRIA}

Art. $1^{\circ}$ Fica criado o Plano Rio Sem Miséria, no âmbito do Estado do Rio de Janeiro, com o objetivo de proporcionar condições dignas de vida às famílias em situação de pobreza extrema, oferecendo-lhes oportunidades para seu pleno desenvolvimento.

$\S 1^{\circ}$ - O Plano Rio Sem Miséria será composto pelos Programas Renda Melhor e Renda Melhor Jovem nos termos desta lei.

$\S 2^{\circ}-$ O Plano Rio Sem Miséria, além dos programas previstos no parágrafo anterior, contempla ações que visem à superação da pobreza extrema de forma sustentável, incidindo sobre os diversos determinantes da pobreza.

$\S 3^{\circ}$ - O Plano Rio Sem Miséria contribuirá para a diminuição efetiva dos índices de doenças que tenham como determinantes as condições socioeconômicas dom indivíduo, em especial a tuberculose e a hanseníase.

Art. $2^{\circ}$ - Para fins do Rio Sem Miséria adotam-se as seguintes definições:

I - família: a unidade nuclear composta por um ou mais indivíduos, eventualmente ampliada por outros indivíduos que contribuam para o rendimento ou tenham suas despesas atendidas por aquela unidade familiar, todos moradores em um mesmo domicílio; 
II - domicílio: o local que serve de moradia à família;

III - renda familiar mensal per capita estimada: renda calculada a partir da aplicação de algoritmo preditor de renda considerando informações do Cadastro Único para Programas Sociais do Governo Federal e benefícios recebidos por meio do Programa Bolsa Família, instituído pela Lei Federal no 10.836/2004;

IV - pobreza extrema: renda familiar mensal per capita estimada abaixo de $\mathrm{R} \$ 100,00$ (cem reais);

V - hiato de pobreza extrema: diferença entre a linha de pobreza extrema e a renda familiar per capita estimada, inferior a $\mathrm{R} \$ 100,00$ (cem reais);

VI - responsável familiar: componente da família e morador do domicílio, com idade mínima de 16 anos e, preferencialmente, do sexo feminino que assume a responsabilidade pelas informações sobre a família.

Parágrafo Único - A Secretaria de Estado de Assistência Social e Direitos Humanos - SEASDH - deverá realizar, periodicamente, diligências in loco para o fiel cumprimento das disposições contidas nos incisos I, II e VI desse artigo.

\section{CAPÍTULO II}

\section{Do Programa Renda Melhor}

Art. $3^{\circ}$ - Fica criado o Programa Renda Melhor, no âmbito do Estado do Rio de Janeiro.

Art. $4^{\circ}-$ O Programa Renda Melhor tem como objetivos:

I - elevar a renda das famílias beneficiárias de forma que estas superem a linha de pobreza extrema;

II - proporcionar às famílias beneficiárias condições para buscarem realizar suas trajetórias de vida com maior autonomia e dignidade;

III - contribuir para a dinamização das economias locais, em particular nas localidades que concentram maiores taxas de pobreza extrema.

Art. $5^{\circ}$ - Serão beneficiários do Programa Renda Melhor as famílias atendidas pelo Programa Bolsa Família que se encontrem em situação de pobreza extrema, nos termos e definições previstos nesta lei.

$\S 1^{\circ}$ - As famílias em situação de extrema pobreza que ainda não são atendidas pelo programa do Governo Federal, poderão se beneficiar do programa 
RIO SEM MISÉRIA, bastando para tanto, se cadastrarem ao programa Bolsa Família no órgão competente da cada município.

$\S 2^{\circ}$ - Para o fiel cumprimento dos critérios estabelecidos no caput deste artigo, será intensificada a estratégia chamada de "Busca Ativa", visando alcançar, identificar e inscrever pessoas que precisam e ainda não recebem o Bolsa Família. $\S 3^{\circ}$ - O pagamento do benefício do programa renda melhor será feito preferencialmente à mulher, devendo, quando possível, ser ela previamente indicada como responsável pela unidade familiar no ato do cadastramento.

Art. $6^{\circ}$ - Os benefícios do Programa serão calculados considerando a renda familiar mensal per capita estimada e os valores pagos pelo Programa Bolsa Família, de forma a eliminar o hiato de pobreza extrema.

Parágrafo Único - O valor mínimo do benefício será $\mathrm{R} \$ 30,00$ (trinta reais) e o valor máximo será $\mathrm{R} \$ 300,00$ (trezentos reais) por família.

Art. $7^{\circ}$ - Os benefícios serão pagos mensalmente, por intermédio do agente operador do Programa Bolsa Família, obedecido o mesmo calendário de pagamentos.

Art. $8^{\circ}$ - As famílias atendidas pelo Programa Renda Melhor permanecerão com os benefícios liberados, mensalmente, para pagamento, salvo na ocorrência das seguintes situações:

I - Descumprimento de responsabilidades e condicionalidades do Programa Renda Melhor, que acarrete bloqueio, suspensão ou cancelamento dos benefícios concedidos;

II - suspensão ou cancelamento dos benefícios do Programa Bolsa Família; III - comprovação de fraude ou prestação deliberada de informa- ções incorretas, quando do cadastramento ou atualização cadastral;

IV - desligamento por ato voluntário do beneficiário ou por determinação judicial;

V - alteração cadastral na família, cuja modificação implique a inadequação ao Programa. 
$\S 1^{\circ}$ - No caso de normalização do cumprimento das condicionalidades do Programa Renda Melhor, o pagamento do benefício será automaticamente restabelecido, sem direito a benefício retroativo.

$\S 2^{\circ}$ - Será desligada do Programa Renda Melhor definitivamente, a família cujo responsável familiar prestar declaração falsa ou usar de qualquer outro meio ilícito e ou fraudulento para a obtenção de vantagens, assegurando o prévio direito de defesa do responsável, na forma do correspondente dispositivo constitucional.

$\S 3^{\circ}-$ Na hipótese do parágrafo anterior, o Ministério Público do Estado do Rio de Janeiro - MPE/RJ será notificado para que promova a responsabilização criminal, na forma dos artigos 297 e 299, do Código Penal.

$\S 4^{\circ}$ - Deverá ser disponibilizada na Rede Mundial de Computadores a relação de todos os beneficiários do Programa Renda Melhor Jovem, constando nome, instituição de ensino e valor do benefício.

Art. $9^{\circ}$ - Os valores dos benefícios do Programa Renda Melhor serão revisados anualmente, podendo sofrer alterações no valor, para mais ou para menos, em conformidade com as modificações identificadas na renda familiar per capita estimada.

Parágrafo Único - Os valores dos benefícios de cada família do Programa Renda Melhor não serão alterados em virtude de flutuações ocorridas nos benefícios do Programa Bolsa Família até nova apuração pela Secretaria de Estado de Assistência Social e Direitos Humanos - SEASDH da renda per capita estimada destas famílias.

Art. 10 - As condicionalidades do Programa Renda Melhor serão as mesmas exigidas pelo Programa Bolsa Famílias previstas no art. $3^{\circ}$ da Lei $n^{o}$ 10.836/2004 e representam as contrapartidas que devem ser cumpridas pelas famílias para a manutenção dos benefícios.

Art. 11 - As famílias beneficiárias do Programa Renda Melhor serão priorizadas na gestão de oportunidades econômicas e sociais a serem coordenadas pelo Governo do Rio de Janeiro. 
Parágrafo Único - As regras da gestão de oportunidades serão definidas por regulamentação, publicadas em Diário Oficial.

Art. 12 - Será de acesso público a relação dos beneficiários e dos respectivos benefícios do Programa a que se refere o caput do art. $1^{\circ}$ desta lei. Parágrafo Único - A relação a que se refere o caput terá divulgação em meios eletrônicos de acesso público e em outros meios previsto em regulamento

Art. 13 - O Termo de Adesão será o instrumento utilizado para formalizar a adesão dos municípios do Estado do Rio de Janeiro ao Programa Renda Melhor. Parágrafo único O Termo de Adesão estabelecerá os compromissos assumidos por cada ente na gestão e execução do Programa Renda Melhor.

Art. 14 - O Governo do Rio de Janeiro estabelecerá a regulamentação complementar necessária à gestão e execução do Programa Renda Melhor.

\section{CAPÍTULO III}

Do Programa Renda Melhor Jovem

Art. 15 - Fica criado o Programa Renda Melhor Jovem, no âmbito do Estado do Rio de Janeiro.

Art. 16 - O Programa Renda Melhor Jovem tem como objetivos:

I - incentivar os jovens beneficiários a se manterem no sistema educacional e a concluírem o Ensino Médio;

II - contribuir para o aumento das taxas de aprovação e conclusão do Ensino Médio no Estado do Rio de Janeiro;

III - contribuir para a redução dos determinantes das vulnerabilidades e dos índices de criminalidade da juventude;

IV - promover o desenvolvimento humano, atuando sobre um dos principais determinantes estruturais da pobreza extrema e de sua reprodução Inter geracional. 
Art. 17 - Serão beneficiários do Programa Renda Melhor Jovem os jovens integrantes de famílias atendidas pelo Programa Renda Melhor que ingressem ou tenham ingressado no ensino médio regular ou profissionalizante da rede estadual com até 18 anos incompletos.

Parágrafo Único - O Governo do Rio de Janeiro poderá incluir jovens que ingressem ou tenham ingressado no ensino médio regular ou profissionalizante da rede estadual com até 18 anos incompletos atendidos em outras estratégias consideradas prioritárias, conforme regulamentação posterior.

Art. 18 - A participação do beneficiário no Programa Renda Melhor Jovem estará sujeita a aceitação formal, do beneficiário e, quando couber, do responsável legal dos critérios previstos no Termo de Adesão ao Programa.

$\S 1^{\circ}$ - A adesão ao Programa a que se refere o caput deste artigo dar- -se-á no momento da abertura da conta pelo aluno e, quando couber, seu responsável legal em instituição bancária a ser definida.

$\S 2^{\circ}-$ O jovem beneficiário deverá ter frequência de $2 / 3$ (dois terços) do total das avaliações bimestrais estaduais - Sistema de Avaliação Bimestral do processo de ensino e aprendizagem nas escolas (SAERJINHO) - por ano, promovidas pela Secretaria de Estado de Educação - SEEDUC, proporcionais ao mês de adesão ao Programa.

$\S 3^{\circ}-\mathrm{O}$ jovem beneficiário deverá realizar nos anos subsequentes ao ano de adesão ao Programa, pelo menos 2 (duas) avaliações bimestrais estaduais Sistema de Avaliação Bimestral do processo de ensino e aprendizagem nas escolas (SAERJINHO) - por ano, promovidas pela Secretaria de Estado de Educação - SEEDUC.

Art. 19 - O participante do Programa Renda Melhor Jovem fará jus a um benefício financeiro - Prêmio de Aprovação - por cada ano concluí- do, com aprovação, no ensino médio, definido conforme critérios a seguir:

I - R \$ 700,00 (setecentos reais) após a confirmação de aprovação na $1^{\mathrm{a}}$ série do ensino médio;

II - R \$ 900,00 (novecentos reais) após a confirmação de aprovação na 2a série do ensino médio; 
III - R \$ 1.000,00 (um mil reais) após a confirmação de aprovação na $3^{\mathrm{a}}$ série do ensino médio;

$\S 1^{\circ}$ - No caso do jovem estar cursando o ensino profissionalizante de 4 (quatro) anos, o Prêmio de Aprovação, após a confirmação de aprovação no quarto ano, será de $\mathrm{R} \$ 1.200,00$ (um mil e duzentos reais).

$\S 2^{\circ}$ - Os prêmios instituídos por esta lei serão depositados anualmente em modalidade de aplicação financeira corrigida financeiramente com base no índice de remuneração da poupança em suas respectivas datas-bases ou em outro índice que venha a substituí-lo, aberta em nome do jovem beneficiário e, quando for o caso, assistido ou representado por seu responsável legal.

Parágrafo Único - Será considerado como desempenho satisfatório as notas obtidas pelo aluno no ENEM, cujos critérios serão regulamentados em portaria conjunta a ser publicada posteriormente pela Secretaria de Estado de Educação SEEDUC e pela Secretaria de Estado de Assistência Social e Direitos Humanos SEASDH.

Art. 20 - O valor contabilizado em favor do beneficiário do Programa Renda Melhor Jovem é de natureza pessoal e intransferível. Parágrafo Único - As regras para os saques e para eventuais devoluções dos valores depositados decorrentes de desligamento do beneficiário do Programa serão definidas por regulamentação.

Art. 21 - A Secretaria de Estado de Assistência Social e Direitos Humanos SEASDH será a responsável pela coordenação das ações do Programa Renda Melhor Jovem, que deverão ser implementadas de forma articulada com a Secretaria de Estado de Educação - SEEDUC e demais entidades públicas federais, estaduais, municipais e da sociedade civil. Parágrafo Único - A Secretaria de Estado de Educação - SEEDUC e a Secretaria de Estado de Assistência Social e Direitos Humanos - SEASDH apoiarão as ações do Programa Renda Melhor Jovem desenvolvidas no âmbito de suas competências.

Disposições Finais e Transitórias

Art. 22 - As despesas decorrentes da execução dos Programas institu- ídos por esta lei correrão por conta de dotações orçamentárias próprias. 
Parágrafo Único - Os recursos do Programa Renda Melhor poderão ser advindos do Fundo Estadual de Combate a Pobreza - FECP, criado pela Lei $\mathrm{n}^{\circ} 4056$ de 30/12/2002 prorrogada pela Lei Complementar nº 139 de 23/12/2010.

Art. 23 - A fruição dos benefícios decorrentes dos programas de que trata a presente lei depende do atendimento cumulativo dos seguintes requisitos, além daqueles previstos expressamente em seu texto:

I - aqueles previstos no respectivo regulamento;

II - residir o beneficiário em município que já seja atendido pelo programa;

III - existência de disponibilidade orçamentária e financeira.

Art. 24 - A expansão dos Programas Renda Melhor e Renda Melhor Jovem dependerá de ato autorizativo do Governador, de acordo com as disponibilidades orçamentárias e previsão na Lei de Diretrizes Orçamentárias.

Art. 25 - Para a execução do Plano Rio Sem Miséria poderão ser firmados convênios, acordos de cooperação, ajustes ou outros instrumentos congêneres, com órgãos e entidades da administração pública federal, dos Estados e dos Municípios, com consórcios públicos, bem como com entidades privadas, na forma da legislação pertinente.

Art. 26 - O Poder Executivo regulamentará, no que couber, a presente lei, por Decreto.

Art. 27 - Esta lei entra em vigor na data de sua publicação.

Rio de Janeiro, 25 de novembro de 2011 


\title{
8.5.
}

\section{Anexo 5}

DECRETO No 43.382 DE 28 DE DEZEMBRO DE 2011

\author{
DISPÕE SOBRE O ÂMBITO DOS PROGRAMAS \\ RENDA MELHOR E RENDA MELHOR JOVEM NO \\ PLANO RIO SEM MISÉRIA, NO ESTADO DO RIO DE \\ JANEIRO, E DÁ OUTRAS PROVIDÊNCIAS.
}

O GOVERNADOR DO ESTADO DO RIO DE JANEIRO, no uso de suas atribuições constitucionais e legais, tendo em vista o que consta o Processo $n^{\circ}$ E23/3297/2011,

\section{CONSIDERANDO:}

- o inciso III, do art. $3^{\circ}$ da Constituição da República Federativa do Brasil de 1988, que define como objetivos fundamentais a erradicação da pobreza e da marginalização e a redução das desigualdades sociais e regionais;

- o inciso X, do art. 23 da Constituição da República Federativa do Brasil de 1988, que prevê a coresponsabilidade de todas as instâncias federativas no combate às causas da pobreza e aos fatores de marginalização, determinando um modelo de gestão compartilhada, com atribuições para cada ente federado;

- a pobreza como um fenômeno complexo que abrange diversas dimensões para além da renda, que limitam as possibilidades de vida dos indivíduos e das famílias, e sua capacidade de se inserir no processo de desenvolvimento da sociedade;

- a instituição dos Programas Renda Melhor e Renda Melhor Jovem, no âmbito do Plano Rio Sem Miséria, o art. 24 da Lei Estadual n ${ }^{\circ}$ 6.088, de 25 de novembro de 2011 e dos Decretos $n^{\circ}$ s 42.949, de 10 de maio de 2011; 42.999, de $01^{\circ}$ de junho de 2011; e 43.257, de 26 de outubro de 2011;

- as taxas municipais de pobreza extrema apuradas pelo Censo IBGE de 2010; e - a elevada concentração da população e o elevado número de famílias em situação de pobreza extrema na Região Metropolitana do Estado do Rio de Janeiro. 


\title{
DECRETA:
}

Art. $1^{\circ}$ - O Plano Rio Sem Miséria é composto dos Programas Renda Melhor e Renda Melhor Jovem.

Art. $2^{\circ}$ - O Programa Renda Melhor, além dos Municípios de Belford Roxo, Japeri, Magé e São Gonçalo, onde já é executado, será implantado em 2012 nos Municípios referidos no Anexo deste Decreto.

Art. $3^{\circ}$ - O Programa Renda Melhor Jovem será implantado nos mesmos municípios do Programa Renda Melhor e no Município do Rio de Janeiro.

Art. $4^{\circ}$ - Este decreto entrará em vigor na data de sua publicação.

Rio de Janeiro, 28 de dezembro de 2011

\section{SÉRGIO CABRAL}

\author{
Área Município \\ Região Metropolitana Duque de Caxias \\ Região Metropolitana Guapimirim \\ Região Metropolitana Itaboraí \\ Região Metropolitana Itaguaí \\ Região Metropolitana Maricá \\ Região Metropolitana Mesquita \\ Região Metropolitana Nilópolis \\ Região Metropolitana Niterói \\ Região Metropolitana Nova Iguaçu \\ Região Metropolitana Paracambi \\ Região Metropolitana Queimados \\ Região Metropolitana São João de Meriti \\ Região Metropolitana Seropédica \\ Região Metropolitana Tanguá \\ Região Baixada Litorânea Araruama
}


Região Baixada Litorânea Saquarema

Região Baixada Litorânea Silva Jardim

Região Centro Sul Fluminense Areal

Região Centro Sul Fluminense Paty do Alferes

Região Centro Sul Fluminense Sapucaia

Região da Costa Verde Paraty

Região Noroeste Fluminense Cambuci

Região Noroeste Fluminense Porciúncula

Região Noroeste Fluminense São José de Ubá

Região Norte Fluminense Campos dos Goytacazes

Região Norte Fluminense Carapebus

Região Norte Fluminense Cardoso Moreira

Região Norte Fluminense Quissamã

Região Norte Fluminense São Francisco de Itabapoana

Região Norte Fluminense São João da Barra

Região Serrana São José do Vale do Rio Preto

Região Serrana São Sebastião do Alto

Região Serrana Sumidouro

Região Serrana Trajano de Moraes

Rio de Janeiro, 11 de maio de 2011

\section{SÉRGIO CABRAL}




\section{6.}

\section{Anexo 6}

DECRETO No 43.568 DE 27 DE ABRIL DE 2012

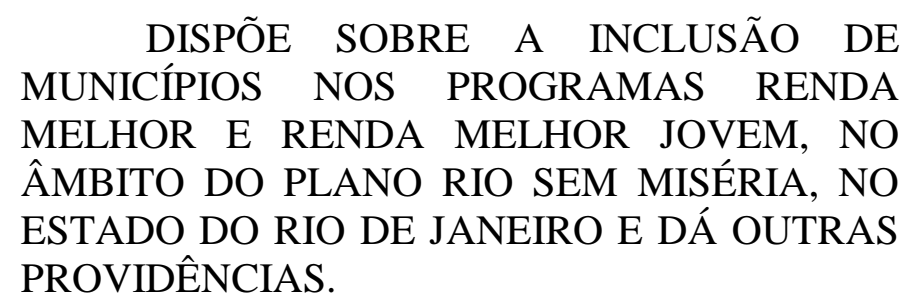

O GOVERNADOR DO ESTADO DO RIO DE JANEIRO, no uso de suas atribuições constitucionais e legais,

\section{CONSIDERANDO:}

- a instituição dos Programas Renda Melhor e Renda Melhor Jovem, no âmbito do Plano Rio Sem Miséria, o art. 24 da Lei Estadual n 6.088, de 25 de novembro de 2011 e dos Decretos $n^{\circ}$ s 42.949, de 10 de maio de 2011; 42.999, de 01 de junho de 2011; e 43.257, de 26 de outubro de 2011;

- as taxas municipais de pobreza extrema apuradas pelo Censo IBGE de 2010; e - as famílias em situação de pobreza extrema que sofreram com o desastre natural em função da elevada precipitação pluviométrica em treze municípios das regiões Norte e Noroeste do Estado do Rio de Janeiro e pelas estratégias pactuadas pelos governos federal e estadual.

\section{DECRETA:}

Art. $1^{\circ}$ - Ficam incluídos os municípios das regiões Norte e Noroeste do Estado referidos no anexo deste Decreto nos Programas Renda Melhor e Renda Melhor Jovem, no âmbito do Plano Rio Sem Miséria. 
Art. $2^{\circ}$ - Ficam ratificados os atos de execução dos referidos Programas praticados nos meses de março e abril de 2012.

Art. $3^{\circ}$ - Este Decreto entrará em vigor na data de sua publicação.

Rio de Janeiro, 27 de abril de 2012

\section{SÉRGIO CABRAL}

Anexo ao Decreto No N3.568/2012 $^{\circ}$

Expansão dos Programas Renda Melhor e Renda Melhor Jovem Regiões Norte e Noroeste (Ano de 2012)

Área Município

Região Noroeste Aperibé

¿ Região Noroeste Bom Jesus do Itabapoana

Região Norte Conceição de Macabu

Região Noroeste Italva

Região Noroeste Itaocara

Região Noroeste Itaperuna

Região Noroeste Laje do Muriaé

Região Norte Macaé

Região Noroeste Miracema

Região Noroeste Natividade

Região Noroeste Santo Antônio de Pádua

Região Norte São Fidelis

Região Noroeste Varre-Sai 


\title{
8.7.
}

\section{Anexo 7}

RESOLUÇÃO SEASDH N 512 DE 11 DE JULHO DE 2013

\begin{abstract}
REGULAMENTA OS PROCEDIMENTOS DA REVISÃO ANUAL DOS VALORES DOS BENEFÍCIOS PAGOS ÀS FAMÍLIAS INCLUÍDAS NO PROGRAMA RENDA MELHOR.
\end{abstract}

\section{O SECRETÁRIO DE ESTADO DE ASSISTÊNCIA SOCIAL E DIREITOS} HUMANOS, no uso de suas atribuições legais,

CONSIDERANDO o disposto no art. $9^{\circ}$ da Lei $\mathrm{n}^{\circ} 6.088$, de 25 de novembro de 2011, que determina a revisão anual dos valores dos benefícios pagos às famílias incluídas no Programa Renda Melhor;

CONSIDERANDO o Acordo de Cooperação Técnica $n^{\circ}$ 008/2012 de19/09/12 celebrado com o Centro de Tecnologia de Informação e Comunicação do Estado do Rio de Janeiro - PRODERJ; e

CONSIDERANDO a necessidade de dar publicidade aos procedimentos utilizados.

\section{DECRETA:}

Art. $1^{\circ}$ - A revisão anual de 2013 dos valores dos benefícios pagos às famílias incluídas no Programa Renda Melhor até dezembro de 2012 será efetivada no pagamento referente ao mês de julho de 2013 e seguirá o calendário de pagamento do Programa Bolsa Família/Renda Melhor.

$\S 1^{\circ}$ - Para efeitos da revisão serão consideradas as informações constantes das bases do Cadastro Único para Programas Sociais do Governo Federal (referência - dezembro de 2012) e os valores constantes da folha de pagamento do Programa Bolsa Família (referência março de 2013) do Estado do Rio de Janeiro.

$\S 2^{\circ}$ - A execução dos procedimentos, incluída a execução do algoritmo preditor de renda, para a apuração dos novos valores e geração da nova relação de beneficiários do Programa Renda Melhor - denominada Folha Raiz 2013 - será 
realizada por meio de processos informatizados e as informações referentes ao processamento serão registradas no Sistema de Gestão do Programa Renda Melhor.

Art. $2^{\circ}$ - Esta Resolução entrará em vigor na data de sua publicação, revogadas as disposições em contrário.

Rio de Janeiro, 11 de julho de 2013

ZAQUEU DA SILVA TEIXEIRA

Secretário de Estado de Assistência Social e Direitos Humanos 


\section{8.}

\section{Anexo 8}

DECRETO No 44.295 DE 12 DE JULHO DE 2013

\section{DISPÕE SOBRE A EXPANSÃO DOS PROGRAMAS RENDA MELHOR E RENDA MELHOR JOVEM, NO ÂMBITO DO PLANO RIO SEM MISÉRIA, NO ESTADO DO RIO DE JANEIRO.}

O GOVERNADOR DO ESTADO DO RIO DE JANEIRO, no uso de suas atribuições constitucionais e legais, tendo em vista o que consta o Processo $n^{\circ} E$ 3/001/1438/2013,

\section{CONSIDERANDO:}

- o inciso III, do art. $3^{\circ}$ da Constituição da República Federativa do Brasil de 1988, que define como objetivos fundamentais a erradicação da pobreza e da marginalização e a redução das desigualdades sociais e regionais;

- o inciso X do art. 23 da Constituição da República Federativa do Brasil de 1988, que prevê a coresponsabilidade de todas as instâncias federativas no combate às causas da pobreza e aos fatores de marginalização, determinando um modelo de gestão compartilhada,com atribuições para cada ente federado;

- a pobreza como um fenômeno complexo que abrange diversas dimensões para além da renda, que limitam as possibilidades de vida dos indivíduos e das famílias, e sua capacidade de se inserir no processo de desenvolvimento da sociedade;

- a instituição dos Programas Renda Melhor e Renda Melhor Jovem, no âmbito do Plano Rio Sem Miséria, o art. 24 da Lei Estadual n ${ }^{\circ}$ 6.088, de 25 de novembro de 2011 e dos Decretos n ${ }^{\circ}$ 42.949, de 10 de maio de 2011, 42.999, de 01 de junho de 2011, e 43.257, de 26 de outubro de 2011;

- que a expansão dos Programas Renda Melhor e Renda Melhor Jovem, no âmbito do Plano Rio Sem Miséria, nos termos do art. 24, da Lei Estadual nº 6.088, de 25 de novembro de 2011, depende de ato autorizativo do Governador, de 
acordo com as disponibilidades orçamentárias e previsão na Lei de Diretrizes Orçamentárias; e

- a implantação dos Programas Renda Melhor e Renda Melhor Jovem, em 51 municípios por meio dos Decretos $\mathrm{n}^{\circ} 43.382$ de 28de dezembro de 2011, e $\mathrm{n}^{\circ}$ 43.568, de 07 de abril de 2012.

\section{DECRETA}

Art. $1^{\circ}$ - Os Programas Renda Melhor e Renda Melhor Jovem serão implantados em 2013 nos municípios referidos no Anexo deste Decreto. Art. $2^{\circ}$ - Este Decreto entrará em vigor na data de sua publicação.

Rio de Janeiro, 12 de julho de 2013

SÉRGIO CABRAL

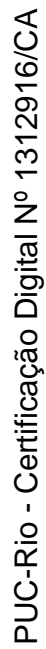

Anexo ao decreto: 
Programa Penda Melhor - Ano Enpansäo 2013

\begin{tabular}{|c|c|}
\hline \multicolumn{2}{|c|}{ Programa Punda Melhor - Ano Erpanato 2013} \\
\hline Aertio & Municipis \\
\hline Regiāo Daikada Litoränea & Armactōo dos Düzios. \\
\hline Pegiāo Baimada Lițorânea & Arraial do Cabo \\
\hline Pesiâo Babada Litoránea & Gabo Frio \\
\hline Realao Babada Litoranea & Cachoeiras de Macacu \\
\hline Repigo Babada Litoranea & Casimiro de Abreu \\
\hline Região Baixada Litoranea & lpuabs Grande \\
\hline Regiāo Buibada Litoranea & Aig Bonito \\
\hline Regibo Babada Litoránea & Big das Ostras \\
\hline Pegiá Babada Litoranea & 5 o Pedro da Aldela \\
\hline Regifo Centro sul Fluminence & Comendador Levy Gasparian \\
\hline Regiäo Centro 5 ul Fluminense & Engenheiro Paulo de Frontin \\
\hline Regiäo Centro Sul Fluminente & Mendes \\
\hline Pegiāo Centro Sul Fluminense & Miguel Pereirs \\
\hline Pesiho Centro Sul Fluminense & Parala do Sul \\
\hline Regido Centro 5 ul Fluminence & Tres Rios \\
\hline Repifo Centro sul Fluminenge & Vassouras \\
\hline Regiáa da Costa Verde & Angra dos Reis \\
\hline Regiao da Couta Verde & Mangaratiba \\
\hline Pegibo Modio Paraiba & Barra do Piraí \\
\hline Regifo Mddio Paraiba & Barra Mansa \\
\hline Regía Medio Paralba & Itatiala \\
\hline Repiáo Medio Paraiba & Pinheiral \\
\hline Regiāo Medio Paraiba & Pirali \\
\hline Pegiāo Medio Puraiba & Porto Real \\
\hline Angiho Modio Paraiba & Quatis; \\
\hline Regiáno Medio Paraiba & Ferende \\
\hline RegiFo Medio Paralba & Aus Claro \\
\hline Regifo Medio Paraiba & Rio das Fiores \\
\hline Regía Medio Paraiba & Valenca \\
\hline Aegiho Modio Paraiba & Volti Pedonda \\
\hline Pegitao Serrana & Bom Jardim \\
\hline Repláo Semana & Cantapalo \\
\hline Repiāo Serrana & Carmo \\
\hline Regiāo Serrana & Cordeiro \\
\hline Pegî̃o Serrana & Duas Barras \\
\hline Pegino Snmnn & Macuro \\
\hline Peglà Semana & Noua Friburgo \\
\hline Regifo Serrana & Petropolis \\
\hline Regiâo Serrana & Santa Maria Madalena \\
\hline Regiāo Serrana & Teresópolis \\
\hline
\end{tabular}




\title{
8.9.
}

\section{Anexo 9}

DECRETO N 8.232, DE 30 DE ABRIL DE 2014

\begin{abstract}
Altera o Decreto $\mathrm{n}^{\circ}$ 5.209, de 17 de setembro de 2004, que regulamenta o Programa Bolsa Família, e o Decreto $n^{\circ}$ 7.492, de 2 de junho de 2011, que institui o Plano Brasil Sem Miséria.
\end{abstract}

A PRESIDENTA DA REPÚBLICA, no uso das atribuições que lhe confere o art. 84, caput, incisos IV e VI, alínea "a", da Constituição, e tendo em vista o disposto na Lei no 10.836, de 9 de janeiro de 2004,

\section{DECRETA:}

Art. 1o O Decreto no 5.209, de 17 de setembro de 2004, passa a vigorar com as seguintes alterações: “Art. 18. O Programa Bolsa Família atenderá às famílias em situa- ção de pobreza e extrema pobreza, caracterizadas pela renda familiar mensal per capita de até $\mathrm{R} \$ 154,00$ (cento e cinquenta e quatro reais) e $\mathrm{R} \$ \quad 77,00 \quad$ (setenta e sete reais), respectivamente. " (NR)

"Art. 19.

I - benefício básico, no valor mensal de $\mathrm{R} \$ 77,00$ (setenta e sete reais), destinado a unidades familiares que se encontrem em situação de extrema pobreza;

II - benefício variável, no valor mensal de $\mathrm{R} \$ 35,00$ (trinta e cinco reais) por beneficiário, até o limite de $\mathrm{R} \$ 175,00$ (cento e setenta e cinco reais) por família, destinado a unidades familiares que se encontrem em situação de pobreza ou extrema pobreza e que tenham em sua composição: de $\mathrm{R} \$ 42,00$ (quarenta e dois reais) por beneficiário, até o limite de $\mathrm{R} \$ 84,00$ (oitenta e quatro reais) por família, destinado a unidades familiares que se encontrem em situação de pobreza 
ou extrema pobreza e que tenham em sua composição adolescentes com idade de dezesseis a dezessete anos matriculados em estabelecimentos de ensino;

V - benefício para superação da extrema pobreza, cujo valor será calculado na forma do $\S 30$, no limite de um por família, destinado às unidades familiares beneficiárias do Programa Bolsa Família que apresentem soma da renda familiar mensal e dos benefícios financeiros previstos nos incisos I a III do caput igual ou inferior a $\mathrm{R} \$ 77,00$ (setenta e sete reais) per capita.

$\S 1^{\circ}$

$\S 3^{\circ} \mathrm{O}$ valor do benefício para superação da extrema pobreza será o resultado da diferença entre $R$ 77,01 (setenta e sete reais e um centavo) e a soma per capita referida no inciso $\mathrm{V}$ do caput, multiplicado pela quantidade de membros da família, arredondado ao múltiplo de $\mathrm{R} \$ 2,00$ (dois reais) imediatamente superior." (NR) Art. 2oO Decreto no 7.492, de 2 de junho de 2011, passa a vigorar com as seguintes alterações:

“Art. 2o

Parágrafo único. Para efeito deste Decreto considera-se em extrema pobreza aquela população com renda familiar per capita mensal de até $\mathrm{R} \$ 77,00$ (setenta e sete reais)." (NR) Art. $3^{\circ}$ Ficam revogadas as alíneas "a" e "b" do inciso V do caput do art. 19 do Decreto no 5.209, de 17 de setembro de 2004.

Art. $4^{\circ}$ Este Decreto entra em vigor na data de sua publicação, com efeitos financeiros a partir de $1^{\circ}$ de junho de 2014.

Brasília, 30 de abril de 2014; 193oda Independência e 126oda República.

\section{DILMA ROUSSEFF}

Guido Mantega

Miriam Belchior

Tereza Campello 


\subsection{0.}

\section{Anexo 10}

\section{Termo de adesão ao Programa Renda Melhor}

O Município de XXXX, Estado do Rio de Janeiro, inscrito no CNPJ/MF sob o $\mathrm{n}^{\circ} \mathrm{XXXXX}$, doravante denominado MUNICÍPIO, neste ato representado pelo Senhor Prefeito XXXXXXX, brasileiro, RG $n^{\circ} 999999999$ IFP/RJ, e CPF $n^{\circ}$ 999.999.999-99, e o Estado do Rio de Janeiro, por intermédio da SECRETARIA ESTADUAL DE ASSISTÊNCIA SOCIAL E DIREITOS HUMANOS, inscrita no CNPJ/MF sob o n ${ }^{\circ}$ 02.932.524/0001-46, situada à Praça Cristiano Otoni s/no $6^{\circ}$ andar, Ed. Dom Pedro II, Centro, Rio de Janeiro/RJ, doravante denominada SEASDH, representada neste ato pelo Secretário de Estado de Assistência Social e Direitos Humanos, Senhor XXXXXX, brasileiro, RG no 99999999-9 IFP/RJ, inscrito no CPF sob o nº 999.999.999-99. CONSIDERANDO: A organização político-administrativa da República Federativa do Brasil compreende a União, os Estados, o Distrito Federal e os Municí- pios, todos autônomos, conforme pacto inscrito no art. 18, da Constituição da República Federativa do Brasil de 1988. O combate às causas da pobreza e aos fatores de marginalização, e a promoção da integração social dos setores desfavorecidos são competências comuns às três esferas de Governo, conforme disposto no inciso X, do art. 23 da Constituição da República Federativa do Brasil de 1988. A realização dos objetivos da República Federativa do Brasil de erradicar a pobreza e a marginalização, assim como de reduzir as desigualdades sociais e regionais para a construção de uma sociedade livre.

justa e solidária previstos nos incisos I e III, do art. $3^{\circ}$, da Constituição da República Federativa de 1988, depende do compartilhamento de responsabilidades, da cooperação e da coordenação de ações e rela- ções intergovernamentais envolvendo a União, os Estados, o Distrito Federal e os municípios, de acordo com a diretriz inscrita no inciso I, do art. 204, da Lei Maior. O dinamismo econômico do Estado do Rio de Janeiro, impulsionado pelos grandes projetos de investimentos e pelos eventos esportivos internacionais a serem realizados no âmbito do Estado, representa uma oportunidade singular para 
ações de fomento à mudança do padrão de desenvolvimento econômico-social da região, com o objetivo de torná-lo sustentável e inclusivo. O Programa Bolsa Família, implantado pelo Governo Federal desde 2003, vem apresentando resultados importantes para a diminuição da pobreza e da desigualdade no Brasil, mas é necessário que ações compartilhadas entre o Estado e os municípios estabeleçam como meta a retirada de todas as famílias da situação de pobreza extrema. A instituição dos Programas Renda Melhor e Renda Melhor Jovem, no âmbito do Plano Rio Sem Miséria, o art. 24 da Lei Estadual n 6.088, de 25 de novembro de 2011 e dos Decretos n42.949, de 10 de maio de 2011; 42.999, de $1^{\circ}$ de junho de 2011; e 43.257, de 26 de outubro de 2011. O Decreto Estadual ${ }^{\circ}$ 43.382, de 28 de dezembro de 2011, que dispõe sobre a expansão dos Programas Renda Melhor e Renda Melhor Jovem, no âmbito do Plano Rio Sem Miséria, no Estado do Rio de Janeiro, e dá outras providências, nos termos da Lei Estadual $n^{\circ}$ 6.088, de 25 de novembro de 2011. O Programa Gestão de Oportunidades Econômicas e Sociais que têm como objetivo articular a oferta de oportunidades econômicas e sociais de inclusão produtiva direcionando a demanda para a popula- ção em situação de pobreza extrema, com vistas a promover a inclusão produtiva das famílias em extrema pobreza. Os recursos financeiros repassados aos cidadãos beneficiários do Programa Renda Melhor representam um instrumento de dinamiza- ção da economia local dos municípios fluminenses. O Programa Renda Melhor foi implementado em caráter piloto no ano de 2011 nos Municípios de Japeri, Belford Roxo e São Gonçalo, conforme previsto no Decreto Estadual $\mathrm{n}^{\circ}$ 42.949/2011. A necessidade de formalizar a adesão dos entes federados ao Programa Renda Melhor, com o objetivo de definir responsabilidades, compromissos e obrigações de ambas as partes para o alcance dos resultados esperados pelo referido Programa e conforme preceitua o art. 10, do Decreto Estadual no 42.949, de 10 de maio de 2011 e no art. 13 da Lei Estadual $n^{\circ} 6.088 / 2011$

RESOLVEM firmar o presente TERMO DE ADESÃO, que será regido pelas seguintes cláusulas e condições:

\section{CLÁUSULA PRIMEIRA - DO OBJETO}


O presente TERMO tem por objeto a adesão do MUNICÍPIO ao Programa Renda Melhor, a fim de cooperar, no âmbito de seu território, com a SEASDH, segundo o previsto no Decreto $n^{\circ} 42.949$, de 10 de maio de 2011 e na Lei Estadual $n^{\circ}$ 6.088 , de 25 de novembro de 2011.

\section{CLÁUSULA SEGUNDA - DOS COMPROMISSOS DO MUNICÍPIO}

O MUNICÍPIO compromete-se, nos termos da legislação vigente, a:

I. Delegar ao gestor municipal do Programa Bolsa Família - PBF, as seguintes atribuições:

a) gestão e coordenação do Programa Renda Melhor;

b) interlocução com a instância local de controle social dos Programas Bolsa Família e Renda Melhor;

c) promover a integração do Programa Renda Melhor com as áreas de saúde, educação, trabalho, assistência social, segurança alimentar, desenvolvimento social dentre outras, quando existentes, visando o desenvolvimento das ações do Programa no âmbito municipal e estadual;

d) articulação com o governo estadual; e

e) promover estratégias de busca ativa de famílias, articulado com a SEASDH, para entrega de cartões do Programa Bolsa Família/Renda Melhor não entregues. II. delegar a responsabilidade para realizar o controle social do Programa Renda Melhor ao conselho ou comitê de controle social do Programa Bolsa Família;

III. realizar a gestão dos benefícios do Programa Renda Melhor às famílias que residem em seu território;

IV. promover, em articulação com os governos estadual e federal, o acesso dos beneficiários do Programa Renda Melhor aos serviços de educação e saúde, a fim de permitir o cumprimento das condicionalidades pelas famílias beneficiárias; V. proceder ao acompanhamento das famílias beneficiárias, em especial atuando nos casos de descumprimento de condicionalidades e outras situações indicativas de vulnerabilidade e de risco social;

VI. estabelecer parcerias com órgãos e instituições municipais, estaduais e federais, governamentais e não governamentais, para a oferta de um cardápio de 
oportunidades econômicas e sociais aos beneficiários do Programa Renda Melhor, especialmente ações de alfabetização, de capacitação profissional e de geração de emprego e renda desenvolvidas em sua esfera de competências.

VII. Reiterar os seguintes compromissos assumidos em pactuação com o Governo Federal para a implementação do Programa Bolsa Família, principalmente:

a) implementar ações de busca ativa com o objetivo de identificar e incluir no Cadastro Único para Programas Sociais todas as famílias em situação de pobreza extrema;

b) realizar o acompanhamento familiar de todas as famílias beneficiárias do Programa Renda Melhor, utilizando os instrumentos informacionais disponíveis e os que serão disponibilizados pelo Estado do Rio de Janeiro;

c) promover a apuração e/ou o encaminhamento, às instâncias cabíveis, de denúncias sobre irregularidades na execução do Programa Renda Melhor no âmbito local;

VIII. Reiterar os seguintes compromissos assumidos em pactuação com o Governo Federal no Protocolo de Gestão Integrada Serviços, Benefícios e Transferência de Renda no âmbito do SUAS :

a) Mapear a ocorrência de situações de vulnerabilidade e riscos, bem como a rede sócio assistencial e das demais políticas setoriais;

b) Atualizar periodicamente o mapeamento das famílias beneficiárias do PBF e do Programa Renda Melhor, com base nas informações disponibilizadas pelo Ministério do Desenvolvimento Social - MDS e pela SEASDH; c

c) Acessar o Sistema de Gestão do Programa Bolsa Família (SIGPBF) e obter as informações das famílias beneficiárias em descumprimento de condicionalidades para a realização do acompanhamento familiar;

d) Disponibilizar aos CRAS ou, onde não houver, para a equipe técnica da Proteção Social Básica - PSB responsável pela implementação da Gestão Integrada, a relação de famílias do PBF e do Programa de Erradicação do Trabalho Infantil - PETI residentes em seu território de abrangência, para o acompanhamento das famílias;

e) Disponibilizar ao CRAS e ao CREAS ou, onde não houver, para a equipe técnica da PSB e da Proteção Social Especial - PSE, a relação completa de 
famílias do PBF e do PETI em situação de descumprimento de condicionalidades pelos motivos relacionados à proteção básica e à proteção especial;

f) Fortalecer o papel de gestão territorial da PSB do CRAS, bem como de oferta, articulação e de referência dos serviços socioassistenciais nos territórios e para tanto: instituir, nos termos dos convênios firmados, que as entidades prestadoras de serviços socioassistenciais do território destinem ao menos 60\% (sessenta por cento) de sua capacidade de atendimento aos usuários encaminhados pelo CRAS; IX. A expansão do número de beneficiários do Programa Renda Melhor, no âmbito municipal, dependerá prioritariamente da adesão ao Programa, bem como da execução regular e bem gerida deste no âmbito local.

X. A adesão do MUNICÍPIO ao Programa e sua execução regular e bem gerida também poderão ser levadas em consideração em processos de destinação voluntária de recursos pela SEASDH, respeitada a legislação que disciplina os programas implementados por este órgão.

XI. Contribuir nas estratégias de mobilização dos possíveis beneficiários do Renda Melhor e Renda Melhor Jovem para que possam conhecer as ofertas de políticas sociais, cursos, e demais oportunidades de inclusão produtiva no âmbito do Programa de Gestão de Oportunidades Econômicas e Sociais.

XII. Acompanhar as famílias e os jovens beneficiários do Programa Renda Melhor Jovem.

XIII Contribuir nas estratégias de mobilização, informação e esclarecimento, no âmbito do Programa Renda Melhor Jovem.

\section{CLÁUSULA TERCEIRA - DOS COMPROMISSOS DA SEASDH}

A SEASDH assumirá as seguintes responsabilidades no âmbito do Programa Renda Melhor:

I. implementar o pagamento mensal de benefícios às famílias beneficiárias, no território do município, conforme disposto no Decreto Estadual n ${ }^{\circ} 42.949 / 2011$; II. tornar disponíveis ao município, de forma rotineira, informações e eventuais bases de dados a respeito de:

a) famílias selecionadas como beneficiárias do Programa Renda Melhor e o valor dos benefícios;

b)cartões não entregues e benefícios não sacados;

c) resultados das ações de fiscalização e auditorias; 
d) resultados de ações de monitoramento do programa e de seus instrumentos operacionais;

III. promover a entrega regular dos cartões do Programa;

IV. articular junto ao município e o agente operador estratégias de busca ativa de famílias para a entrega de cartões devolvidos do Programa Bolsa Família/Renda Melhor;

V. apoiar a capacitação dos agentes envolvidos e prestar suporte técnico e operacional na gestão e execução do Programa Renda Melhor e do Cadastro Único, compreendendo os gestores, técnicos, profissionais das áreas de assistência social, saúde e educação, conselheiros, entre outros, em articulação com o município;

VI. promover a articulação das políticas e a integração do Programa Renda Melhor com as ações executadas no âmbito da Gestão de Oportunidades Econômicas e Sociais, destinadas ao atendimento das famílias beneficiárias do Programa Renda Melhor;

VII. tornar disponíveis ao município, aos cidadãos e aos demais interessados, canais de comunicação, para o recebimento de sugestões, consultas e denúncias sobre eventuais irregularidades na implementação do Programa Renda Melhor; VIII. enviar à instância de controle social do Estado, responsável pelo acompanhamento do Programa Renda Melhor, cópia do presente Termo de Adesão; e

IX. priorizar as famílias beneficiárias do Programa Renda Melhor no acompanhamento familiar desenvolvido no âmbito da política de assistência social e nas ações de gestão de oportunidades econômicas e sociais a serem coordenadas pelo Governo do Estado do Rio de Janeiro

\section{CLÁUSULA QUARTA - DA DENÚNCIA OU DA RESCISÃO}

Os PARTÍCIPES poderão denunciar, por escrito, a qualquer tempo, e rescindir de pleno direito, o presente TERMO, devendo ser imputadas as responsabilidades das obrigações decorrentes do prazo em que tenha vigido e creditados os benefícios adquiridos no mesmo período.

$\S 1^{\mathrm{o}}$ Constitui motivo para rescisão deste TERMO, independentemente do instrumento de sua formalização, o descumprimento de quaisquer de suas 
cláusulas ou das normas estabelecidas na legisla- ção vigente, pela superveniência de norma legal ou de fato que o torne material ou formalmente inexequível.

$\S 2^{\circ}$ A denúncia deverá ser comunicada por escrito e mediante notificação prévia com 60 (sessenta) dias de antecedência, somente produzindo efeitos a partir desta data.

$\S 3^{\circ}$ A denúncia ou rescisão não implicará o dever de indenização entre os PARTÍCIPES.

$\S 4^{\circ}$ A rescisão do presente TERMO deverá observar os princípios da ampla e prévia defesa e do contraditório

\section{CLÁUSULA QUINTA - DAS ALTERAÇÕES}

O presente Termo poderá ser alterado durante a sua vigência, de comum acordo entre os partícipes, mediante Termo Aditivo devidamente justificado e autorizado, sendo vedada a modificação do objeto.

\section{CLÁUSULA SEXTA - DO PESSOAL}

O presente instrumento não acarreta solidariedade entre os PARTÍCIPES, sendo certo que os profissionais envolvidos na execução das atividades decorrentes da vigência deste Termo permanecerão subordinados às entidades às quais estejam originalmente vinculados, independentemente de eventual atuação que venham a ter no curso da execução do objeto deste instrumento.

Parágrafo único. A celebração de contrato entre município e terceiros, para a execução de serviços vinculados ao objeto deste Termo, não acarretará a solidariedade direta solidária ou subsidiária do Estado, bem como não constituirá vínculo funcional ou empregatício, ou a responsabilidade pelo pagamento de encargos civis, trabalhistas, previdenciários, sociais, fiscais, comerciais, assistenciais ou outro de qualquer natureza 


\section{CLÁUSULA SÉTIMA - PRAZO DE VIGÊNCIA}

O presente instrumento vigerá pelo prazo de 36 (trinta e seis) meses, contados a partir da data de publicação no Diário Oficial do Estado, podendo ser prorrogado ou alterado mediante termo aditivo, desde que atenda ao interesse público.

Parágrafo único. A prorrogação do prazo de vigência do Termo será admitida, quando demonstrado o atendimento das metas pactuadas no presente ajuste

\section{CLÁUSULA OITAVA - DOS RECURSOS FINANCEIROS}

O presente TERMO não envolve transferência de recursos financeiros entre os partícipes.

$\S 1^{\circ}$ Cada PARTÍCIPE será responsável pela alocação de recursos financeiros próprios para cada custeio das atividades que constituem suas obrigações na execução do objeto deste instrumento.

$\S 2^{\circ}$ Eventuais despesas decorrentes do presente TERMO, no que diz respeito ao Estado do Rio de Janeiro correrão por conta de dotações orçamentárias próprias, consoante a pertinente legislação de regência, bem ainda serão formalizadas pelos cabíveis instrumentos jurídicos

\section{CLÁUSULA NONA - DA PUBLICAÇÃO}

O extrato do presente termo será publicado pela SEASDH no Diário Oficial do Estado.

\section{CLÁUSULA DÉCIMA - DO FORO}

Fica eleito o Foro da Comarca da Capital do Estado do Rio de Janeiro para dirimir eventuais controvérsias decorrentes do presente instrumento, excluído qualquer outro, por mais privilegiado que seja.

Rio de Janeiro, de (mês) de xxxx. 
Nome do secretário Secretário de Estado de Assistência Social e Direitos Humanos

Nome do prefeito Prefeito do Município de XXXXX

Testemunhas:

Nome:

CPF:

Nome:

CPF:

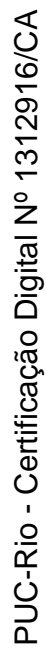




\subsection{1.}

Anexo 11

Planilhas de número de beneficiários x valor repassado do Programa Renda Melhor

a) Projeto Piloto

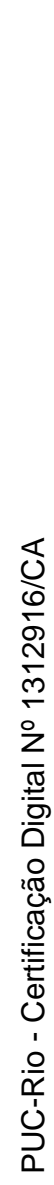

\begin{tabular}{|c|c|c|c|c|c|}
\hline \multicolumn{6}{|c|}{2011} \\
\hline \multirow{5}{*}{ 응 } & \multicolumn{4}{|c|}{ Folha Raiz } & \multirow[b]{2}{*}{$\begin{array}{l}\text { Investimento total anual } \\
\text { (valor disponibilizado) }\end{array}$} \\
\hline & Municipio & $\begin{array}{l}\text { Quantidade de } \\
\text { familias } \\
\text { beneficiárias }\end{array}$ & Valor Previsto & $\begin{array}{l}\text { Valor médio } \\
\text { mensal recebido } \\
\text { por familia }\end{array}$ & \\
\hline & Japeri & 5.534 & $\mathrm{R} \$ 420.497,00$ & $\mathrm{R} \$ 75,98$ & $R \$ 2.801 .810,00$ \\
\hline & Belford Roxo & 20.298 & $R \$ 1.706 .068,00$ & $R \$ 84,05$ & $R \$ 9.582 .025,00$ \\
\hline & São Gonçalo & 26.197 & $\mathrm{R} \$ 1.969 .207,00$ & $R \$ 75,17$ & $R \$ 8.926 .302,00$ \\
\hline & Total & 52.029 & $\mathrm{R} \$ 4.095 .772,00$ & $\mathrm{R} \$ 78,72$ & $R \$ 21.310 .137,00$ \\
\hline
\end{tabular}

Tabela 1 - Investimento do Programa Renda Melhor em 2011

Fonte: SGPRM 
b) Expansão 2012

\begin{tabular}{|c|c|c|c|c|c|}
\hline \multicolumn{6}{|c|}{2012} \\
\hline \multirow{5}{*}{$\frac{8}{8}$} & \multicolumn{4}{|c|}{ Fottu Ful: } & \multirow[b]{2}{*}{ 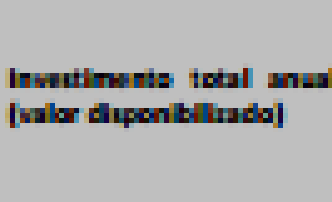 } \\
\hline & M_-nkpla & 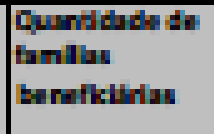 & Wuler Frwht: & 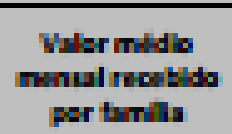 & \\
\hline & Iyfari & 514 & 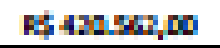 & A\$P,M & ap 4.Mn \\
\hline & DriterdAz= & m.ni & 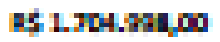 & FHAYI & 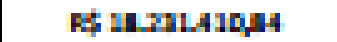 \\
\hline & Hatonpla & ans & sLFtndo & $F+131$ & 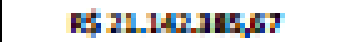 \\
\hline Erawkida & Mtod & 10.71 & "4n+т.1400 & $\mathrm{FHn}$ & F; F.41,41, \\
\hline \multirow{27}{*}{ 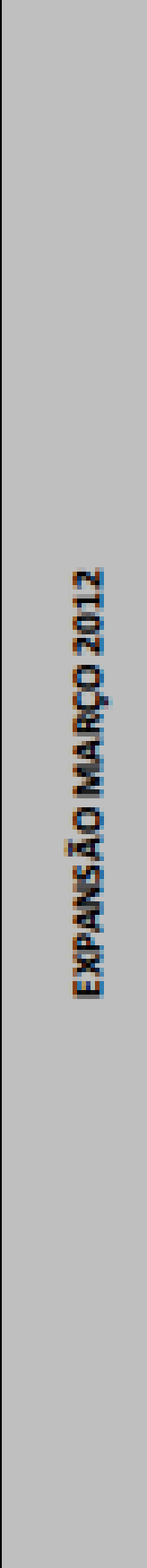 } & Aratums & 5 nu & 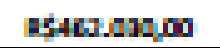 & FमpIj1 & 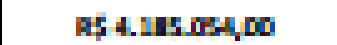 \\
\hline & Anul & IEI & Fłn.1n,po & Fthesus & 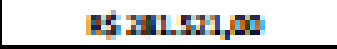 \\
\hline & Dintur & Ex & Fundu, & Finn & ydrampin \\
\hline & 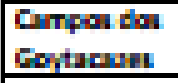 & 15.25 & A5induses & FHEH & E4lams, \\
\hline & Gripob_-1 & 45 & FHSPHDO & Far $x$ & F L1.wamos \\
\hline & $\begin{array}{l}\text { Drdas } \\
\text { Monir }\end{array}$ & 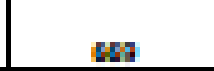 & Fondon & cthn & ympun \\
\hline & $\begin{array}{l}\text { Ducpen in } \\
\text { Drils }\end{array}$ & 15.mi & 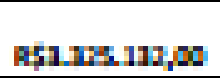 & FमHp & F \\
\hline & Euptrititi & 7111 & 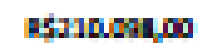 & For $\mathrm{H}$ & AP $1.14 .94,00$ \\
\hline & Huberal & 1144 & cum.4t50 & stmps & RP Gumas, \\
\hline & hapui & $4 \mathrm{CL}$ & 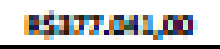 & Fory & Ap 1.4ms, \\
\hline & Murlat & 275 & mมx.m10 & Fमpryo & AP 1.125.217, \\
\hline & Manquts & S1P1 & msichHon & 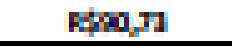 & AF A.SH.141, DO \\
\hline & Nepclin & $4 M T$ & мมн.ามต & Fमn & ap 1.11日.m, \\
\hline & Fherd & 11u & 5ru.s1. & F+15,y1 & AP cuarus, \\
\hline & Fow ly-up & 11.411 & 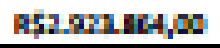 & Fon & F4 24.7nsupos \\
\hline & Pricantil & 151 & 2111.450 & Fher & AF $1.10 \mathrm{nos}, \mathrm{co}$ \\
\hline & Praby & 1 non & sict.7no & Fon & chosyos \\
\hline & $\begin{array}{l}\text { Patyda } \\
\text { Aline }\end{array}$ & 1115 & H1z0:50 & Fal 1 & As $1.0 n g, \infty$ \\
\hline & Rari_-nula & $\mathbf{m}$ & EGUIST & Fon 14 & cisinasos \\
\hline & Guinude & 751 & cua.ring & FHa & AF G.724LG, \\
\hline & Dumrd & 15 & Far.ipge & 410,5: & aringes \\
\hline & 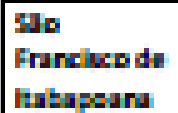 & IAF & siptesion & Fan 4 & AF $1.30 x+35$, \\
\hline & \begin{tabular}{|l} 
Woblot t \\
arm \\
\end{tabular} & $1.3 \%$ & Falsmpo & FWn & semporos \\
\hline & $\begin{array}{l}\text { Moblo dh } \\
\text { Morti }\end{array}$ & 14.400 & 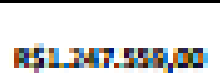 & FLELA & F4 uswactos \\
\hline & $\begin{array}{l}\text { Wobuld } \\
\text { Lat }\end{array}$ & IFs & Fhr.41200 & $64 \pi x$ & sisengon \\
\hline & $\begin{array}{l}\text { Wo bud do } \\
\text { Woln do FI: } \\
\text { Proto }\end{array}$ & Na & FLo sm, & Ftopgen & SGLIT,00 \\
\hline & 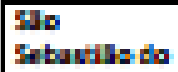 & 44 & Fqpangos & F+hHA] & E \\
\hline
\end{tabular}




\begin{tabular}{|c|c|c|c|c|c|}
\hline & Ahe & & & & \\
\hline & Supurila & 201 & Etonjus,po & Fthen & csmanpo \\
\hline & Sucumna & $7 \mathrm{Mr}$ & Bunduson & Fars & 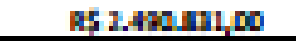 \\
\hline & Seropldia & In & 0415.15100 & Fring & As $1.12 \sin , 0$ \\
\hline & Hulrsin & $1.7 \mathrm{~h}$ & 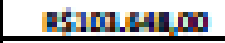 & Fins & cherpso \\
\hline & Sunba-to & 15 & Ebanstipo & FPIS & chargo \\
\hline & Turnd & LWH & 9111.47100 & FardD & a $1.127 m, \infty$ \\
\hline & $\begin{array}{l}\text { Trulans dy } \\
\text { Mornt }\end{array}$ & $\mathbf{s i t}$ & E\$po 113,00 & FHnil & y+1415,0 \\
\hline & Apmifol & 211 & 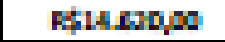 & FPHIJI & plapm, \\
\hline 플 & $\begin{array}{l}\text { Den hua } \\
\text { do } \\
\text { likapsura }\end{array}$ & 1.145 & 04114.17700 & $F H \pi$ & 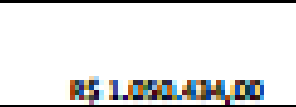 \\
\hline$\frac{7}{8}$ & 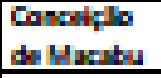 & 벼니 & Fonduses & FHr11 & Esm.41m, \\
\hline 8 & Erolsu & 5 & R4Mm, & MAA,Ys & ysmongos \\
\hline \pm & Hoscras & 111 & EATHEP & oxrye & simpon \\
\hline$\mu$ & Auserury & $7 \mathrm{mp}$ & 941.1200 & FHAP & AF $1.07 \times 1 \times 10$ \\
\hline $\bar{x}$ & $\begin{array}{l}\text { Lujid: } \\
\text { Murtud }\end{array}$ & 45 & Finn worpo & ofrus & cimigup \\
\hline 2 & Mhai & 4.15 & monmsm & Fhen & ap 1.mons, \\
\hline if & Mrestata & $1 \mathrm{nu}$ & Fansuses & Fuld.12 & 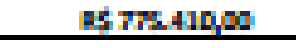 \\
\hline 2 & Hothudast & Mu & Essisspes & Ftan & 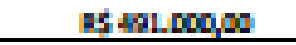 \\
\hline$\frac{1}{x}$ & $\begin{array}{l}\text { Furis } \\
\text { Anteris du } \\
\text { Pldus }\end{array}$ & 100 & 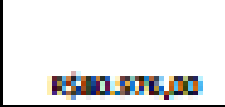 & Fheng & son ras, \\
\hline & anflih & 1.50 & 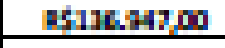 & Fthen & FF 1.1.2. \\
\hline & vam-Fy & 201 & Etsoges & Fan & Hginjug \\
\hline & Toty & Ans? & 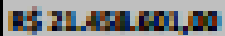 & Ftous.11 & LFOMIS1, \\
\hline
\end{tabular}

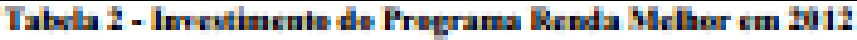
Fats: ACrisy 
c) Expansão 2013

\begin{tabular}{|c|c|c|c|c|c|}
\hline \multicolumn{6}{|c|}{2013} \\
\hline \multirow{5}{*}{$\frac{8}{5}$} & \multicolumn{4}{|c|}{ Fothu Ful: } & \multirow[b]{2}{*}{ 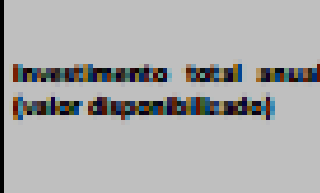 } \\
\hline & Hunldipla & 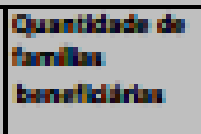 & Valor Frwhito & 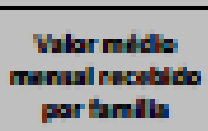 & \\
\hline & Inpet & 4.117 & Fansmo: & $\mathrm{F}, \mathrm{m}, \mathrm{M}$ & y+rannos \\
\hline & Enterd Fare & LeTs & ㅂ.1.14.71, & FA 10,1 & 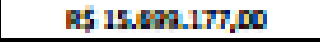 \\
\hline & Fllo Gonds & M.114 & 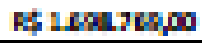 & Fat 30,10 & 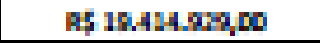 \\
\hline $\begin{array}{l}\text { Haphis: } \\
\text { in }\end{array}$ & Hunt & 1201 & 04.24411100 & Fo, $\mathrm{F}_{1} \mathrm{H}$ & AF IDELAm, no \\
\hline \multirow{27}{*}{$\begin{array}{l}3 \\
8 \\
3 \\
3 \\
3\end{array}$} & Mranuma & 4.151 & 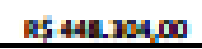 & 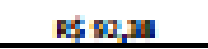 & of \\
\hline & Ared & mu & esinupo & sin 104a & F415.71410 \\
\hline & Cunked & 4 & 4xm8 & Ex Bgon & $6472 m 10$ \\
\hline & $\begin{array}{l}\text { Cumpen den } \\
\text { Copreun }\end{array}$ & $11 \mathrm{CH}$ & 41.1H.Mge & Fits & op $11.40 x$ man, 00 \\
\hline & Eurapntul & $4 \pi$ & Exx+100 & Fin, & 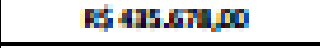 \\
\hline & $\begin{array}{l}\text { Curdon: } \\
\text { Mentry }\end{array}$ & 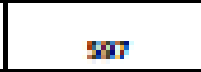 & $4+141,0$ & 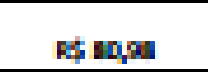 & FPH.AM \\
\hline & $\begin{array}{l}\text { Duqued bu } \\
\text { Cudin } \\
\end{array}$ & Mess & 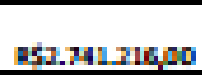 & F 5,1 & A5 11.51100, , \\
\hline & Gupinin & 1.110 & R: 11270100 & F4 & 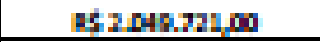 \\
\hline & Hetari & 2.51 & R5 611.74:0 & Fan & Hachlnoo \\
\hline & tryul & 1.74 & As 141.5700 & est $p_{1}, 11$ & gansmon \\
\hline & Hatle & 2.178 & Ar 2417490 & F t 14 & g2monson \\
\hline & Hexts & 4.nI & 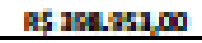 & Fan & Etrssumo \\
\hline & H14p=li & 1.45 & A; 2 L.:H & 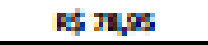 & 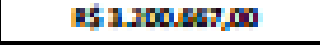 \\
\hline & Mard & E.17s & R; 511.71500 & $\mathrm{~F}, \mathrm{mp} n$ & "5.174.1.10 \\
\hline & How lpag. & 11047 & 41.411.104ag & F $m, n$ & 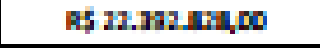 \\
\hline & Fumsunt & 1.412 & R; 14rmon & 05100 & 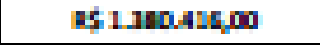 \\
\hline & Faraty & 1.21 & MLATD & Fit n, & F4n:mon \\
\hline & \begin{tabular}{|l} 
Faty do \\
Mthre
\end{tabular} & $1.1 \mathrm{~s}$ & Af 100.5500 & F & 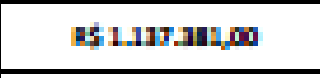 \\
\hline & Feritureul & $\mathrm{mo}$ & tssougo & 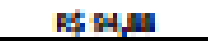 & E4512.740 \\
\hline & Qurinudba & sas & A5 519.740 & Exps & 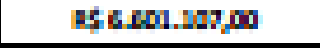 \\
\hline & Q-hun: & min & sos.mo & E. 10,70 & 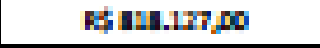 \\
\hline & 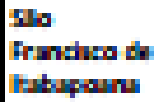 & $1.2 n$ & 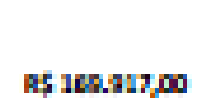 & EF $\pi, 47$ & 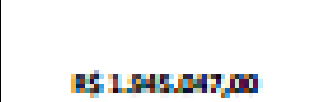 \\
\hline & 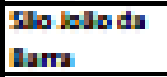 & as & 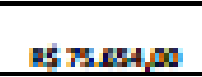 & 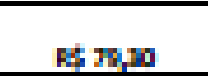 & F\$19.000 \\
\hline & $\begin{array}{l}\text { Folvoded } \\
\text { Herti }\end{array}$ & 11.144 & 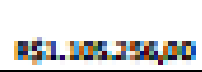 & F & 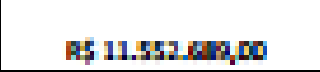 \\
\hline & $\begin{array}{l}\text { glu bad in } \\
\text { uts }\end{array}$ & $x$ & 419.150 & F & F.241.16,10 \\
\hline & $\begin{array}{l}\text { Flo bedide } \\
\text { Wuk do fio } \\
\text { Finte }\end{array}$ & ant & 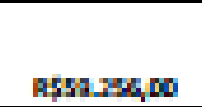 & 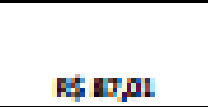 & 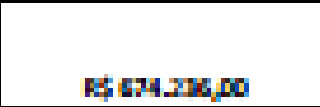 \\
\hline & $\begin{array}{l}\text { Slo } \\
\text { Sbarilost } \\
\text { Mi: }\end{array}$ & min & aspan, 00 & ES G, & 6.124.950 \\
\hline
\end{tabular}




\begin{tabular}{|c|c|c|c|c|c|}
\hline & Epunt & $6 \pi$ & sㄹ.1160 & Estr & EAsmeno \\
\hline & Equrin & 2.74 & RF JLAnton & FH & 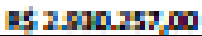 \\
\hline & Eroptated & 2.111 & AS Jun.uson & $F_{1} m_{1}$ & 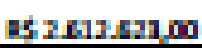 \\
\hline & Fualurthin & 1.00 & 4nлts & F $\pi, 15$ & 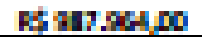 \\
\hline & Eurilian & $7 \pi$ & sasto & Fin & FHondo \\
\hline & Turpu & 1.210 & warmp & Ftrirs & E1.1459400 \\
\hline & $\begin{array}{l}\text { Trajure th } \\
\text { Morun }\end{array}$ & 41 & cys11po & FH mp & F4H.7450 \\
\hline \multirow{13}{*}{ 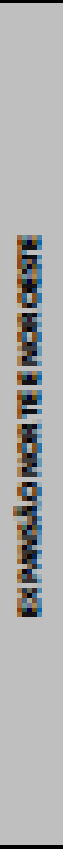 } & 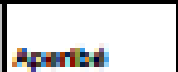 & $m$ & trichos & $F+1, \infty$ & F IHMn \\
\hline & 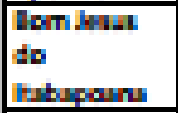 & 1.111 & A: 112.1200 & E, a,j & М.1. \\
\hline & $\begin{array}{l}\text { Conserifl: } \\
\text { in Mucula }\end{array}$ & $2 \pi$ & ssicaso & F Fa, 10 & F 50.170 \\
\hline & Itrita & 4 & $x+1 . x+10$ & FA 14,0 & F+11.5n \\
\hline & Huceura & Ho & 400spipo & $\mathrm{F}, 11,11$ & F Estando \\
\hline & tyanus: & 2.14 & As 18.5500 & Fin & 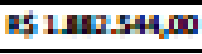 \\
\hline & $\begin{array}{l}\text { Lry do } \\
\text { Hurts }\end{array}$ & 50 & spospos & ES ME & Fa11:AHDO \\
\hline & Hent & 4.511 & As 412.1200 & $\mathrm{FA}, \mathrm{H}$ & symosion \\
\hline & Hirsertu & $\mathrm{ms}$ & $0471 n 1,0$ & $\mathrm{FH}+\mathrm{F}, \mathrm{T}$ & F4 1.17410 \\
\hline & Hotiduch & sis & y Harpo & Fat ary & Fastugn \\
\hline & 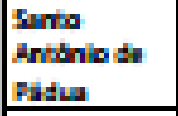 & 1.04 & As 100.12400 & FA BuT & Fa11.7ng \\
\hline & Fling Fill & 1.420 & FमLantod & Fa, & H1.M.1450 \\
\hline & Bumbil & 619 & SMA4ID & FEr & Fusmo \\
\hline \multirow{16}{*}{$\frac{\mathrm{g}}{\mathrm{g}}$} & $\begin{array}{l}\text { Mrypdsin } \\
\text { Enh }\end{array}$ & 1.247 & A5 12.450 & $\mathrm{~F} \operatorname{sg}$ & E1.411.11400 \\
\hline & $\begin{array}{l}\text { Amaclis } \\
\text { La les labs }\end{array}$ & 519 & AHבPRD & FA BAL & F $201 \sin$ \\
\hline & $\begin{array}{l}\text { Mrridu to } \\
\text { Cutes }\end{array}$ & IIII & crasta & FF mar & F $40 x \cdot 2 \pi n$ \\
\hline & \begin{tabular}{|l} 
Durra do \\
First
\end{tabular} & 1.811 & As 117.2150 & $\mathrm{FH} \mathrm{nI}$ & Ft10.150 \\
\hline & Ism Mun & 2.774 & A5 $7 x .41700$ & $\mathrm{FH}, \mathrm{a}$ & 41.154.1750 \\
\hline & Iom lund n & $\pi$ & Eglatajou & F, 1,6 & F $241.7 n 10$ \\
\hline & Cubofin: & s.115 & As 45T.5no & FEx & E211745m \\
\hline & $\begin{array}{l}\text { Cuhowiras } \\
\text { in Mucas }\end{array}$ & 1.411 & Fill7.4Fod & Fing & F Surmo \\
\hline & Cuntanda & $\operatorname{sit}$ & Assing co & Fiso & Farma \\
\hline & Curne & 27 & AFHAS, Do & F n,w & 62417110 \\
\hline & 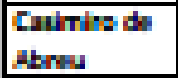 & 세시 & S74.16000 & $\mathrm{F}, \mathrm{mg}$ & F111.117.10 \\
\hline & $\begin{array}{l}\text { Comirduder } \\
\text { Ler } \\
\text { Euputun } \\
\end{array}$ & 24 & AFPHALO & 2111,10 & F 1119min \\
\hline & Conde: & 4 & AHASIDO & FHA & F 35.410 .50 \\
\hline & Dun Eиты & IH & คP.4.0m, & $\mathrm{F}, \mathrm{A}, \mathrm{n}$ & 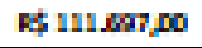 \\
\hline & 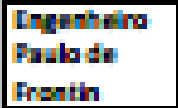 & MI & A5.11.1r, DO & FH Th, & $F+14.790$ \\
\hline & $\begin{array}{l}\text { hrobu } \\
\text { prind }\end{array}$ & 75 & arp.7ndo & 01044 & FAHATR \\
\hline
\end{tabular}




\begin{tabular}{|c|c|c|c|c|c|}
\hline & Fithis & 1.87 & APLTHLO & Fit ripl & F $194 m, 10$ \\
\hline & Howes & $m$ & s19.11480 & Fan & salstas \\
\hline & Murpuritu & $\mathrm{m}$ & expars & Eng & F $117 \operatorname{mos}$ \\
\hline & Henth & 45 & 0 tescos & F4 m, n & 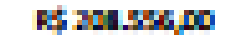 \\
\hline & 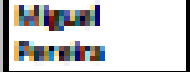 & in & AFELAITL & 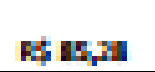 & Fas.tho \\
\hline & $\begin{array}{l}\text { Hsil } \\
\text { Friture }\end{array}$ & 2.17 & FP 17.0. & FH MAL & FHATH_n \\
\hline & $\begin{array}{l}\text { Farriba ds } \\
\text { Eul }\end{array}$ & 1.177 & AP 1HLEFIO & $y 107, \mathrm{LD}$ & FEsahy \\
\hline & Frindpedin & 4.715 & As 451.41.0 & E4 mal & Es.19.42, 0 \\
\hline & Fintwird & 45 & ofrs1118 & E $1, \mathrm{z}$ & Fł 17.5410 \\
\hline & Firul & In & Exrogs & $510, \pi$ & F\$ 112.7100 \\
\hline & Ferio Dnal & $m$ & $\sin 111,0$ & $\mathrm{Faph}$ & FF 115.410 100 \\
\hline & Quath & HI & singugu & FA mal & FH AHANDO \\
\hline & Enwind & 1.417 & AF 11L.MH & FA $A_{1}, \mathrm{H}$ & Fáps.mo \\
\hline & Elog Lonits & $1 . \mathrm{nu}$ & ap 151.1150 & Fat Ans & Find and \\
\hline & 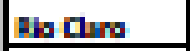 & $4 m$ & sanngu & FAs & Fiscring \\
\hline & \begin{tabular}{|l|} 
Dto du! \\
Henu
\end{tabular} & $w$ & E104A & 111414 & FA 197.4HNO \\
\hline & \begin{tabular}{|l|} 
Dlo tus \\
Duma!
\end{tabular} & 1.45 & AF 11F.14: & Fat & FAst.74DO \\
\hline$\frac{5}{5}$ & $\begin{array}{l}\text { Fursu Hati } \\
\text { Hadury }\end{array}$ & Is & t9.114.0 & FH EAL & FH 242.417. I0 \\
\hline & 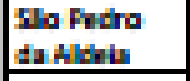 & 1.1 .51 & A. 113.21100 & Fin & 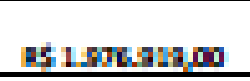 \\
\hline & Trinudoulh & 1.111 & A5 100.210 & FA 40 & 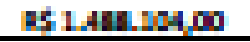 \\
\hline 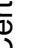 & Trinflou & 1.155 & ar yth.s. & y105s & 31.100 .1450 \\
\hline & Wuknj & 2.251 & AF JDC.21100 & $\mathrm{F}+\mathrm{m}, 11$ & F 75.1610 \\
\hline$F$ & Fusura & 1.111 & AF 14.1LAO & $5120 \times$ & $\mathrm{F}+\mathrm{TH} \mathrm{GH} \mathrm{CO}$ \\
\hline & \begin{tabular}{|l} 
Watu \\
Endonds
\end{tabular} & 4.0.1 & As 15.71100 & F, 20,10 & c1.rugram \\
\hline & Total & Me.sm & ef: MrManes & atsin & HMinasson \\
\hline
\end{tabular}

Tabola 1 - In ruthenie de Pregrama Rrnda Mrlhor em Dil3 
8.12.

Anexo 12

\section{LEI No 10.836, DE 9 DE JANEIRO DE 2004.}

$\underline{\text { Regulamento }}$

Conversão da MPv n n $^{\circ} 32$, de 2003
Cria o Programa Bolsa Família e dá outras providências.

O PRESIDENTE DA REPÚBLICA, Faço saber que o Congresso Nacional decreta e eu sanciono a seguinte Lei:

Art. 1ํFica criado, no âmbito da Presidência da República, o Programa Bolsa Família, destinado às ações de transferência de renda com condicionalidades.

Parágrafo único. O Programa de que trata o caput tem por finalidade a unificação dos procedimentos de gestão e execução das ações de transferência de renda do Governo Federal, especialmente as do Programa Nacional de Renda Mínima vinculado à Educação - Bolsa Escola, instituído pela Lei n ${ }^{\circ} 10.219$, de 11 de abril de 2001, do Programa Nacional de Acesso à Alimentação - PNAA, criado pela Lei n o 10.689 , de 13 de junho de 2003, do Programa Nacional de Renda Mínima vinculada à Saúde - Bolsa Alimentação, instituído pela Medida Provisória n o 2.206-1, de 6 de setembro de 2001, do Programa Auxílio-Gás, instituído pelo Decreto $\mathrm{n}^{\circ} 4.102$, de 24 de janeiro de 2002, e do Cadastramento Único do Governo Federal, instituído pelo Decreto no 3.877, de 24 de julho de 2001.

Art. $2^{\mathrm{o}}$ Constituem benefícios financeiros do Programa, observado o disposto em regulamento:

I - o benefício básico, destinado a unidades familiares que se encontrem em situação de extrema pobreza;

H- o benefício variável, destinado a unidades familiares que se encontrem em situação de pobreza e extrema pobreza e que tenham em sua composição gestantes, nutrizes, crianças entre 0 (zero) e 12 (doze) anøs ou adolescentes até 15 (quinze) anes.

II - o benefício variável, destinado a unidades familiares que se encontrem em situação de pobreza e extrema pobreza e que tenham-em sua composição 
erianças entre zero e doze anøs ou adolescentes até quinze anos, sendo pago até $\theta$ limite de três benefícios por família; (Redação dada pela Medida Provisória no 411, de 2007)

III o benefício variável, vinculado ao adolescente destinado a unidades familiares que se encentrem em sitnação de pobreza- ou extrema pobreza- que tenham em sua composição adolescentes com idade entre dezesseis e dezessete anos, sendo pago até o limite de dois benefícios por família. (Incluído pela Medida Provisória $\mathrm{n}^{\circ}$ 411, de 2007)

H o benefício variável, destinado a unidades familiares que se encontrem em situação de pobreza e extrema pobreza e que tenham em sua composição gestantes, nutrizes, crianças entre 0 (zero) e 12 (doze) anøs ou adolescentes até 15 (quinze) anos, sendo pago até o limite de 3 (três) benefícios por família; (Redação dada pela Lei $\mathrm{n}^{\mathrm{0}}$ 11.692,

II - o benefício variável, destinado a unidades familiares que se encontrem em situação de pobreza e extrema pobreza e que tenham em sta composição gestantes, nutrizes, crianças entre zero e doze anos ou adolescentes até quinze anos, sendo pago até o limite de cinco benefícios por família; e (Redação dada pela Medida Provisória no 535, de 2011)

II - o benefício variável, destinado a unidades familiares que se encontrem em situação de pobreza e extrema pobreza e que tenham em sua composição gestantes, nutrizes, crianças entre 0 (zero) e 12 (doze) anos ou adolescentes até 15 (quinze) anos, sendo pago até o limite de 5 (cinco) benefícios por família; $\quad$ (Redação dada pela Lei $\mathrm{n}^{\circ} 12.512$, de 2011)

III - o benefício variável, vinculado ao adolescente, destinado a unidades familiares que se encontrem em situação de pobreza ou extrema pobreza e que tenham em sua composição adolescentes com idade entre 16 (dezesseis) e 17 (dezessete) anos, sendo pago até o limite de 2 (dois) benefícios por família. (Redação dada pela Lei $n^{\circ} 11.692$, de 2008)

IV - o benefício para superação da extrema pobreza na primeira infância, ne limite de um por família, destinado às unidades familiares beneficiárias do Programa Belsa Família e que, cumulativamente: (Incluído pela Medida Provisória no 570 , de 2012) 
a) tenham em sua composição crianças de zero a seis anos de idade; e (Incluído pela Medida Provisória n ${ }^{\circ}$ 570, de 2012)

b) apresentem soma da renda familiar mensale dos benefícios financeiros previstos nos incisos I a III igual ou inferior a $R \$ 70,00$ (setenta reais) per eapita. (Inclúde pela Medida Proviséria no 570, de 2012)

IV o benefício para superação da extrema pøbreza na primeira infância, no limite de 1 ( $\mathrm{um})$ por família, destinado às unidades familiares beneficiárias do Programa Bolsa Família que, cumulativamente: (Incluído pela Lei n ${ }^{\circ} 12.722$, de 2012)

a) tenham em sua composição crianças de 0 (zero) a 6 (seis) anøs de idade; e (Incluído pela Lei no 12.722 , de 2012)

IV o benefício para superação da extrema pobreza, no limite de um por família, destinado às unidades familiares beneficiárias do Programa Bolsa Família e que, cumulativamente: (Redação dada pela Medida Provisória no 590, de 2012)

a) tenham em sua composição crianças e adolescentes de zero a quinze anøs de idade;e (Redação dada pela Medida Proviséria no 590, de 2012)

IV - o benefício para superação da extrema pobreza, no limite de um por família, destinado às unidades familiares beneficiárias do Programa Bolsa Família e que, cumulativamente: (Redação dada pela Lei n ${ }^{\circ} 12.817$, de 2013)

a) tenham em sua composição crianças e adolescentes de 0 (zero) a 15 (quinze) anos de idade; e (Redação dada pela Lei $n^{\circ} 12.817$, de 2013)

b) apresentem soma da renda familiar mensal e dos benefícios financeiros previstos nos incisos I a III igual ou inferior a $\mathrm{R} \$ 70,00$ (setenta reais) per capita. (Incluído pela Lei $\mathrm{n}^{\circ} 12.722$, de 2012)

$\S 1^{\mathrm{o}}$ Para fins do disposto nesta Lei, considera-se:

I - família, a unidade nuclear, eventualmente ampliada por outros indivíduos que com ela possuam laços de parentesco ou de afinidade, que forme um grupo doméstico, vivendo sob o mesmo teto e que se mantém pela contribuição de seus membros; 
II - nutriz, a mãe que esteja amamentando seu filho com até 6 (seis) meses de idade para o qual o leite materno seja o principal alimento; (Revogado pela Medida Provisória ${ }^{\circ}$ 411, de 2007).

III - renda familiar mensal, a soma dos rendimentos brutos auferidos mensalmente pela totalidade dos membros da família, excluindo-se os rendimentos concedidos por programas oficiais de transferência de renda, nos termos do regulamento.

$\S 2^{\ominus} \theta$ valor do benefício mensal a que se refere 0 inciso I do caput será de $\mathrm{R} \$ 50,00$ (cinqüenta reais) e será concedido a famílias com renda per capita de até $\mathrm{R} \$ 50,00$ (cinqüienta reais).

$\S 3^{\ominus}-0$ valor do benefício mensal a que se refere 0 inciso II do caput será de $\mathrm{R} \$ 15,00$ (quinze reais) por beneficiário, até o limite de $\mathrm{R} \$ 45,00$ (quarenta e einco reais) por família beneficiada e será concedido a famílias com renda per eapita de até $\mathrm{R} \$ 100,00$ (cem reais).

$\S 4^{\ominus} \mathrm{A}$ família beneficiária da transferência a que se refere o inciso I do caput poderá receber, cumulativamente, o benefício a que se refere 0 inciso II do caput, ebservado o limite estabelecido no $\$ 3^{\ominus}-$

$\S 5^{\ominus} A$ família euja renda per capita mensal seja superior a $R \$ 50,00$ (cinqüienta reais), até o limite de $\mathrm{R} \$ 100,00$ (cem reais), receberá exclusivamente o benefício a que se refere 0 inciso II do caput, de acordo com sua composição, até $\quad 0$ limite estabelecido no $\$ 3^{\ominus}$.

$\$ 2^{\Theta}-O$ valor do benefício básico será de $R \$ 58,00$ (cinqüenta-e oito reais) por mês, concedido a famílias com renda familiar mensal per capita de até $R \$$ 60,00 (sessenta reais). (Redação dada pela Medida Provisória nº 411, de 2007) $\S 3^{\ominus}$ - Serão concedidos a famf́lias com renda familiar mensal per capita de até R\$ 120,00 (cento- vinte reais), dependendo de sta composição: (Redaçãodada pela Medida Provisória $\mathrm{n}^{\mathrm{0}} \quad 411$, de 2007 ) I - o benefício variável no valor de $\mathrm{R} \$ 18,00$ (dezoito reais); e (Inclú́do pela Medida Provisória $\quad \mathrm{n}^{\circ} \quad 411$, de $\quad$ 2007)

II o benefício variável vinculado ao adolescente no valor de $R \$ 30,00$ (trinta reais). (Incluído pela Medida Provisória $\mathrm{n}^{\circ} \quad 411$, de 2007) $\S 4^{\ominus}-$ Os benefícios financeires previstos nos incisos I, He II do caput deste attigo poderão ser pages cummlativamente às fammlias beneficiárias, observados os 
limites fixados nos citados incisos IIe III. (Redação dada pela Medida Provisória

\begin{tabular}{llll}
$\mathrm{n}^{\circ}$ & 2007) \\
\hline
\end{tabular}

$\S 5^{\ominus}$ A família cuja renda familiar mensal per capita esteja compreendida entre os valores estabelecidos no $\$ 2^{\theta}$ e no $\$ 3^{\theta}$ receberá exclusivamente os benefícios a que se referem os incisos 1 e II do capht deste artigo, respeitalos os limites fixados nesses incisos. (Redação dada pela Medida Provisória n $^{\circ} 411$, de $\underline{2007)}$

§ 2 $\mathrm{O}$ valor do benefício básico será de $\mathrm{R} \$ 58,00$ (cinqüenta e oito reais) por mês, concedido a famílias com renda familiar mensal per capita de até $\mathrm{R} \$$ 60,00 (sessenta reais). (Redação dada pela Lei $\mathrm{n}^{\circ} 11.692$, de 2008)

§ 3ํㅡㄹ Serão concedidos a famílias com renda familiar mensal per capita de até $\mathrm{R} \$ 120,00$ (cento e vinte reais), dependendo de sua composição: (Redação dada pela Lei $\mathrm{n}^{\mathrm{o}} 11.692$, de 2008)

I - o benefício variável no valor de $\mathrm{R} \$ 18,00$ (dezoito reais); e (Redação dada pela Lei $\mathrm{n}^{\mathrm{o}} 11.692$, de 2008)

II - o benefício variável, vinculado ao adolescente, no valor de R $\$ 30,00$ (trinta reais). (Redação dada pela Lei $\mathrm{n}^{\circ} 11.692$, de 2008)

$\S 4^{\ominus}-$ Os benefícios financeiros previstos nos incisos I, He III do caput deste artigo poderão ser pagos cumulativamente às famílias beneficiárias, observados os limites fixados nos citados incisos II e III. (Redação dada pela Lei n 11.692 , de $\underline{2008)}$

$\S 4^{\ominus}$-Os benefícios financeiros previstos nos incisos I, II, III e IV do caput poderão ser pagos cumulativamente às famílias beneficiárias, observados os limites fixados nos citados incisos II, III e IV. (Redação dada pela Medida Provisória no 570, de 2012)

$\S 4^{\mathrm{o}}$ Os benefícios financeiros previstos nos incisos I, II, III e IV do caput poderão ser pagos cumulativamente às famílias beneficiárias, observados os limites fixados nos citados incisos II, III e IV. $\quad$ (Incluído pela Lei n ${ }^{\circ} 12.722$, de 2012)

$\S 5^{\circ}$ A família cuja renda familiar mensal per capita esteja compreendida entre os valores estabelecidos no $\S 2^{2}$ e no $\quad \S \quad 3^{0}$ deste artigo receberá 
exclusivamente os benefícios a que se referem os incisos II e III do caput deste artigo, respeitados os limites fixados nesses incisos. $\quad$ (Redação dada pela Lei $\mathrm{n}^{\circ}$ $\underline{11.692, \text { de 2008) }}$

$\S 6^{0}$ Os valores dos benefícios e os valores referenciais para caracterização de situação de pobreza ou extrema pobreza de que tratam os $\S \S 2^{\underline{0}}$ e $3^{\circ}$ poderão ser majorados pelo Poder Executivo, em razão da dinâmica socioeconômica do País e de estudos técnicos sobre o tema, atendido o disposto no parágrafo único do art. $6^{\circ}$.

$\S 7^{\circ}$ Os atuais beneficiários dos programas a que se refere o parágrafo único do art. $1^{\circ}$, à medida que passarem a receber os benefícios do Programa Bolsa Família, deixarão de receber os benefícios daqueles programas.

$\S 8^{\circ}$ Considera-se benefício variável de caráter extraordinário a parcela do valor dos benefícios em manutenção das famílias beneficiárias dos Programas Bolsa Escola, Bolsa Alimentação, PNAA e Auxílio-Gás que, na data de ingresso dessas famílias no Programa Bolsa Família, exceda o limite máximo fixado neste artigo.

$\S 9^{\circ} \mathrm{O}$ benefício a que se refere o $\S 8^{\circ}$ será mantido até a cessação das condições de elegibilidade de cada um dos beneficiários que lhe deram origem.

$\S$ 10. O Conselho Gestor Interministerial do Programa Bolsa Família poderá excepcionalizar o cumprimento dos critérios de que trata o $\S 2^{\circ}$, nos casos de calamidade pública ou de situação de emergência reconhecidos pelo Governo Federal, para fins de concessão do benefício básico em caráter temporário, respeitados os limites orçamentários e financeiros.

$\S 11$. Os benefícios a que se referem os incisos Ie II do-caput serão pagos, mensalmente, por meio de cartão magnético bancário, fornecido pela Caixa Econômica Federal, com a respectiva identificação do responsável mediante $\theta$ Número de Identificação Social- NIS, de uso do Governo Federal. \$12. Os benefícios poderão, também, ser pagos por meio de contas especiais de depósito a vista, nos termos de resoluçẽes adotadas pelo Banco Central do Brasil.

$\$ 11$. Os benefícios a que se referem os incisos I, He III docaput deste 
artigo serão pagos, mensalmente, por meio de cartão magnético bancário fornecido pela Caixa Econômica Federal, com a respectiva identificação do responsável mediante o Número de Identificação Social- NIS, de uso do Governø Federal. (Redação dada pela Medida Provisória no 411, de 2007) \$12. Os benefícios poderão ser pagos por meio das seguintes modalidades de contas, nos termos de resoluções adotadas pelo Banco Central do Brasil: (Redação dada pela Medida Provisória $\mathrm{n}^{\circ}$ 411, de 2007) I contas-correntes de depésito à vista; (Incluído pela Medida Provisória no 411, de 2007) II - contas especiais de depósito à vista; (Incluído pela Medida Provisória no $\underline{411,}$ de 2007)

III contas contábeis; e (Incluído pela Medida Provisória nº 411, de 2007) IV outras espécies de contas que venham a ser criadas. (Incluído pela Medida Provisória $n^{\circ} 411$, de 2007)

$\$ 11$. Os benefícios a que se referem os incisos I, He III do caput deste artige serão pages, mensalmente, por meio de cartão magnético bancário fornecido pela Caixa Econômica Federal, com a respectiva identificação do responsável, mediante o Número de Identificação Social-NIS, de uso do Governo Federal. (Redação dada pela Lei n ${ }^{\circ} 11.692$, de 2008)

\$11. Os benefícios financeiros previstos nos inciso I, II, III e IV do caput serão pagos, mensalmente, por meio de cartão magnético bancário fornecido pela Caixa Econômica Federal com a identificação do responsável, mediante o Número de Identificação Social NIS, de uso do Governo federal. (Redação dada pela Medida Provisória n $n^{\circ}$ 570, de 2012)

$\S$ 11. Os benefícios financeiros previstos nos incisos I, II, III e IV do caput serão pagos, mensalmente, por meio de cartão magnético bancário fornecido pela Caixa Econômica Federal com a identificação do responsável, mediante o Número de Identificação Social - NIS, de uso do Governo Federal. $\quad$ (Redação dada pela Lei $\mathrm{n}^{\circ} 12.722$, de 2012)

$\S 12$. Os benefícios poderão ser pagos por meio das seguintes modalidades de contas, nos termos de resoluções adotadas pelo Banco Central do Brasil: (Redação dada pela Lei no 11.692, de 2008) 
I - contas-correntes de depósito à vista; (Incluído pela Lei $\mathrm{n}^{\circ} 11.692$, de $\underline{2008)}$

II - contas especiais de depósito à vista; (Incluído pela Lei $\mathrm{n}^{\circ} 11.692$, de $\underline{2008)}$

III - contas contábeis; e (Incluído pela Lei n 11.692, de 2008)

IV - outras espécies de contas que venham a ser criadas. (Incluído pela Lei ${ }^{\circ}$ $\underline{11.692, \text { de 2008) }}$

$\S 13$. No caso de créditos de benefícios disponibilizados indevidamente ou com prescrição do prazo de movimentação definido em regulamento, os créditos reverterão automaticamente ao Programa Bolsa Família.

$\S$ 14. O pagamento dos benefícios previstos nesta Lei será feito preferencialmente à mulher, na forma do regulamento.

§ 15. O benefício para superação da extrema pobreza na primeira infância corresponderá ao valor necessário para que a soma da renda familiar mensale dos benefícios financeiros supere o valor de $R \$ 70,00$ (setenta reais)per capita, e será ealeulado por faixas de renda. (Incluído pela Medida Provisória no 570, de 2012) $\S 15$. O benefício para superação da extrema pobreza na primeira infâneia corresponderá a v valor necessário para que a soma da renda familiar mensal e dos benefícios financeiros supere o valor de $R \$ 70,00$ (setenta reais)per capita e será ealculado por faixas de renda. (Incluído pela Lei $n^{\circ} 12.722$, de 2012)

$\S 15$. O benefício para superação da extrema pobreza corresponderá a a valor necessário para que a soma da renda familiar mensal e dos benefícios financeiros supere o valor de $\mathrm{R} \$ 70,00$ (setenta reais) per capita. (Redação dada pela Medida Proviséria no 590, de 2012)

$\S 15$. O benefício para superação da extrema pobreza corresponderá ao valor necessário para que a soma da renda familiar mensal e dos benefícios financeiros supere o valor de $\mathrm{R} \$ 70,00$ (setenta reais) per capita. (Redação dada pela Lei $\mathrm{n}^{\mathbf{0}}$ $\underline{12.817, \text { de 2013) }}$

§ 16. Caberá ao Poder Executivo: (Incluído pela Medida Provisória no 570, de 2012) 
I- definir as faixas de renda familiar per capita es respectivos valores a serem pagos a títtlo de benefício para superação da extrema pobreza na primeira infância, conforme previsto no $\$ 15$; e (Incluído pela Medida Provisória no 570 , de $\underline{\underline{2012)}}$

H ajustar, de acordo com critério a ser estabelecido-em ato específico, $\theta$ valor definido para a renda familiar per capita, para fins do pagamento do benefício para superação da extrema pobreza na primeira infâneia. Incluído pela Medida Provisória no 570, de 2012)

§16. Caberá ao Poder Executivo: (Incluído pela Lei no 12.722, de 2012)

$I$ - definir as faixas de renda familiar per capita e os respectivos valores a serem pagos a título de benefício para superação da extrema pobreza na primeira infância, conforme previsto no $\$ 15$; e (Incluído pela Lei no 12.722, de 2012)

II ajustar, de acordo com critério a ser estabelecido em ato específico, $\theta$ valor definido para a renda familiar per capita, para fins do pagamento do benefício para superação da extrema pobreza na primeira infância. (Inclú́do pela Lein 12.722 , de 2012)

§ 16. Caberá ao Poder Executivo ajustar, de acordo com critério a ser estabelecido em ato específico, o valor definido para a renda familiar per capita, para fins do pagamento do benefício para superação da extrema pobreza. (Redação dada pela Medida Provisória no 590, de 2012)

$\S$ 16. Caberá ao Poder Executivo ajustar, de acordo com critério a ser estabelecido em ato específico, o valor definido para a renda familiar per capita, para fins do pagamento do benefício para superação da extrema pobreza. (Redação dada pela Lei no 12.817 , de 2013)

I - (revogado); (Incluído pela Lei n ${ }^{\circ} 12.817$, de 2013)

II - (revogado). (Incluído pela Lei n ${ }^{\circ} 12.817$, de 2013)

$\S 17$. Os beneficiários com idade a partir de 14 (quatorze) anos e os mencionados no inciso III do caput deste artigo poderão ter acesso a programas e cursos de educação e qualificação profissionais.(Incluído pela Lei $\mathrm{n}^{\circ} 12.817$, de 2013) 
Art. $2^{\circ}$ A. A partir de $1^{\circ}$ de março de 2013 , o benefício previsto no inciso IV do caput do art. $2^{\circ}$ será estendido, independentemente da observância da alínea "a", às famílias beneficiárias que apresentem soma da renda familiar mensale dos benefícios financeiros previstos nos incisos I a III do caput do art. $2^{\circ}$, igual ou inferior a $\mathrm{R} \$ 70,00$ (setenta reais) per capita. (Inclúdo pela Medida Proviséria no 607, de 2013) (Vigência encerrada)

Art. 2ํ-A. A partir de $1^{\circ}$ de março de 2013, o benefício previsto no inciso IV do caput do art. $2^{\mathrm{o}}$ será estendido, independentemente do disposto na alínea $a$ desse inciso, às famílias beneficiárias que apresentem soma da renda familiar mensal e dos benefícios financeiros previstos nos incisos I a III do caput do art. $2^{\circ}$, igual ou inferior a $\mathrm{R} \$ 70,00$ (setenta reais) per capita. $\underline{\text { (Incluído pela Lei } \mathrm{n}^{\circ} 12.817 \text {, de 2013) }}$

Art. 3ํㅗ A concessão dos benefícios dependerá do cumprimento, no que couber, de condicionalidades relativas ao exame pré-natal, ao acompanhamento nutricional, ao acompanhamento de saúde, à freqüência escolar de $85 \%$ (oitenta e cinco por cento) em estabelecimento de ensino regular, sem prejuízo de outras previstas em regulamento.

Parágrafóninico. O acompanhamento da freqüência escolar relacionada aө benefício previsto no inciso III do art. $2^{\Theta}$-eonsiderará setenta e cinco por cento de freqüiencia, em conformidade com o previsto no inciso VI do art. 24 da Lei $\mathrm{n}^{\ominus 9} 9.394$, de 20 de dezembro de 1996. (Incluído pela Medida Provisória nº 411, de 2007)

Parágrafo único. $\mathrm{O}$ acompanhamento da freqüência escolar relacionada ao benefício previsto no inciso III do caput do art. 20 desta Lei considerará $75 \%$ (setenta e cinco por cento) de frequiência, em conformidade com o previsto no inciso VI do caput do art. 24 da Lei $\mathrm{n}^{\circ} 9.394$, de 20 de dezembro de 1996. (Incluído pela Lei $\mathrm{n}^{\circ} 11.692$, de 2008)

Art. 4º Fica criado, como órgão de assessoramento imediato do Presidente da República, o Conselho Gestor Interministerial do Programa Bolsa Família, com a finalidade de formular e integrar políticas públicas, definir diretrizes, normas e procedimentos sobre o desenvolvimento e implementação do Programa Bolsa 
Família, bem como apoiar iniciativas para instituição de políticas públicas sociais visando promover a emancipação das famílias beneficiadas pelo Programa nas esferas federal, estadual, do Distrito Federal e municipal, tendo as competências, composição e funcionamento estabelecidos em ato do Poder Executivo.

Art. 5ㅇ $\mathrm{O}$ Conselho Gestor Interministerial do Programa Bolsa Família contará com uma Secretaria-Executiva, com a finalidade de coordenar, supervisionar, controlar e avaliar a operacionalização do Programa, compreendendo o cadastramento único, a supervisão do cumprimento das condicionalidades, o estabelecimento de sistema de monitoramento, avaliação, gestão orçamentária e financeira, a definição das formas de participação e controle social e a interlocução com as respectivas instâncias, bem como a articulação entre o Programa e as políticas públicas sociais de iniciativa dos governos federal, estadual, do Distrito Federal e municipal.

Art. $6^{0}$ As despesas do Programa Bolsa Família correrão à conta das dotações alocadas nos programas federais de transferência de renda e no Cadastramento Único a que se refere o parágrafo único do art. $1^{\circ}$, bem como de outras dotações do Orçamento da Seguridade Social da União que vierem a ser consignadas ao Programa.

Parágrafo único. O Poder Executivo deverá compatibilizar a quantidade de beneficiários do Programa Bolsa Família com as dotaçẽes orçamentárias existentes.

Parágrafo único. O Poder Executivo deverá compatibilizar a quantidade de beneficiários e de benefícios financeiros específices do Programa Bolsa Famfllia com as dotações orçamentárias existentes. (Redação dada pela Medida Provisória no 590 , de 2012)

Parágrafo único. O Poder Executivo deverá compatibilizar a quantidade de beneficiários e de benefícios financeiros específicos do Programa Bolsa Família com as dotações Orçamentárias existentes.(Redação dada pela Lei $\mathrm{n}^{\circ} 12.817$, de $\underline{2013)}$

Art. 7ํㅡㄹete à Secretaria-Executiva do Programa Bolsa Família promover os atos administrativos e de gestão necessários à execução orçamentária 
e financeira dos recursos originalmente destinados aos programas federais de transferência de renda e ao Cadastramento Único mencionados no parágrafo único do art. $1^{\circ}$.

$\S 1^{\text {o }}$ Excepcionalmente, no exercício de 2003, os atos administrativos e de gestão necessários à execução orçamentária e financeira, em caráter obrigatório, para pagamento dos benefícios e dos serviços prestados pelo agente operador e, em caráter facultativo, para o gerenciamento do Programa Bolsa Família, serão realizados pelos Ministérios da Educação, da Saúde, de Minas e Energia e pelo Gabinete do Ministro Extraordinário de Segurança Alimentar e Combate à Fome, observada orientação emanada da Secretaria-Executiva do Programa Bolsa Família quanto aos beneficiários e respectivos benefícios.

$\S 2^{\circ}$ No exercício de 2003 , as despesas relacionadas à execução dos Programas Bolsa Escola, Bolsa Alimentação, PNAA e Auxílio-Gás continuarão a ser executadas orçamentária e financeiramente pelos respectivos Ministérios e órgãos responsáveis.

$\S 3^{\circ}$ No exercício de 2004, as dotações relativas aos programas federais de transferência de renda e ao Cadastramento Único, referidos no parágrafo único do art. $1^{\circ}$, serão descentralizadas para o órgão responsável pela execução do Programa Bolsa Família.

Art. 8ํㅜ A execução e a gestão do Programa Bolsa Família são públicas e governamentais e dar-se-ão de forma descentralizada, por meio da conjugação de esforços entre os entes federados, observada a intersetorialidade, a participação comunitária e o controle social.

$\S 1^{\Theta}$ A execução e a gestão descentralizadas referidas no caput serão implementadas mediante adesão voluntária dos Estados, Distrito Federal e Municípios ao Programa Bolsa Família. (Incluído pela Medida Provisória $n^{\circ} \quad 462$, de 2009)

$\S 2^{\ominus}$-Fica instituído o Índice de Gestão Descentralizada do Programa Bolsa Famfllia IGD, para utilização em âmbito estadual, distrital e municipal, cujos parâmetros serão regulamentados pelo Poder Executivo, e destinado a: (Incluído pela Medida Proviséria $n^{\circ}$ 462, de 2009) 
I medir os resultados da gestão descentralizada, com base na attação do gestor estadual, distrital ou municipal na execução dos procedimentes de cadastramente, na gestão de benefícios e de condicionalidades, na articulação intersetorial, na implementação das açẽes de desenvolvimento das famílias beneficiárias e nө acompanhamento e exectção de procedimentos de controle; (Inclúdo pela Medida Provisória no 462 , de 2009)

II - incentivar a obtenção de resultados qualitativos na gestão estadual, distrital e municipal do Programa; e (Incluído pela Medida Provisória no ${ }^{\circ}$ 462, de $\underline{2009)}$

HI - calcular o montante de recurses a ser transferido aes entes federados a título de apoio financeiro. (Incluído pela Medida Provisória no 462, de 2009)

$\S 3^{\ominus}$ A União transferirá, obrigatoriamente, aøs entes federados que aderirem ao Programa Bolsa Família recursos para apoio financeiro às ações de gestão e execução descentralizada do Programa, desde que alcancem índices mínimes no IGD. (Inclúde pela Medida Provisória no 462 , de 2009)

$\S 4$ - Para a execução do previsto neste artigo, o Poder Executivo Federat regulamentará: (Incluído pela Medida Provisória n n 462, de 2009)

I- os procedimentos e as condições necessárias para adesão ao Programa Bolsa Família, incluindo as obrigaçẽes dos entes respectivos; (Incluído pela Medida Proviséria no 462 , de 2009)

H os instrumentos, parâmetros e procedimentos de avaliação de resultados e da qualidade de gestão em âmbito estadual, distrital e municipal; e (Incluído pela Medida Provisória n ${ }^{\circ}$ 462, de 2009)

HI os procedimentos e instrumentos de controle e acompanhamento da execução do Programa Bolsa Família pelos entes federados. (Incluído pela Medida Provisória no 462, de 2009)

$\S 5^{\ominus}$-Os resultados alcançados pelo ente federado na gestão do Programa Bolsa Família, aferidos na forma do $\S 2^{\ominus}$, inciso I, serão considerados como prestação de contas dos recursos transferidos. (Incluído pela Medida Provisória no 462, de 2009)

$\S \sigma^{\ominus}-$ Os Estados, O Distrito Federale os Municípios submeterão stas prestaçẽes de contas às respectivas instâncias de controle social, previstas no art. $9^{\ominus}$, e em caso de não aprovação, os recurses financeirøs transferidos na forma do $\S$ $3^{\ominus}$-deverão ser restituídos pelo ente federado ao respectivo Fundo de Assistência 
Social, na forma regulamentada pelo Poder Executivo Federal. (Incluído pela Medida Provisória no 462 , de 2009)

$\S 7^{\theta}-0$ montante total dos recursos de que trata 0 \& $3^{\ominus}$ não poderá exceder a três por cento da previsão orçamentária total relativa ao pagamento de benefícios do Programa Bolsa Famillia, devendo o Poder Executivo fixar os limites e-os parâmetros mínimos para a transferência de recursos para cada ente federado.(Incluído pela Medida Provisória n ${ }^{\circ}$ 462, de 2009)

$\S 1^{\text {ọ }}$ A execução e a gestão descentralizadas referidas no caput serão implementadas mediante adesão voluntária dos Estados, do Distrito Federal e dos Municípios ao Programa Bolsa Família. (Incluído pela Lei no 12.058, de 2009)

$\S 2^{\underline{o}}$ Fica instituído o Índice de Gestão Descentralizada do Programa Bolsa Família - IGD, para utilização em âmbito estadual, distrital e municipal, cujos parâmetros serão regulamentados pelo Poder Executivo, e destinado a: (Incluído pela Lei $\mathrm{n}^{\circ} 12.058$, de 2009)

I - medir os resultados da gestão descentralizada, com base na atuação do gestor estadual, distrital ou municipal na execução dos procedimentos de cadastramento, na gestão de benefícios e de condicionalidades, na articulação intersetorial, na implementação das ações de desenvolvimento das famílias beneficiárias e no acompanhamento e execução de procedimentos de controle; (Incluído pela Lei no 12.058 , de 2009)

II - incentivar a obtenção de resultados qualitativos na gestão estadual, distrital e municipal do Programa; e (Incluído pela Lei n ${ }^{\circ} 12.058$, de 2009)

III - calcular o montante de recursos a ser transferido aos entes federados a título de apoio financeiro. (Incluído pela Lei n ${ }^{\circ} 12.058$, de 2009)

$\S 3^{\text {o }}$ A União transferirá, obrigatoriamente, aos entes federados que aderirem ao Programa Bolsa Família recursos para apoio financeiro às ações de gestão e execução descentralizada do Programa, desde que alcancem índices mínimos no IGD. (Incluído pela Lei no 12.058, de 2009)

§ 4ํ Para a execução do previsto neste artigo, o Poder Executivo Federal regulamentará: (Incluído pela Lei n ${ }^{\circ} 12.058$, de 2009) 
I - os procedimentos e as condições necessárias para adesão ao Programa Bolsa Família, incluindo as obrigações dos entes respectivos; (Incluído pela Lei ${ }^{\circ}$ $\underline{12.058, \text { de 2009) }}$

II - os instrumentos, parâmetros e procedimentos de avaliação de resultados e da qualidade de gestão em âmbito estadual, distrital e municipal; e (Incluído pela Lei $\mathrm{n}^{\mathrm{o}} 12.058$, de 2009)

III - os procedimentos e instrumentos de controle e acompanhamento da execução do Programa Bolsa Família pelos entes federados. (Incluído pela Lei no $\underline{12.058, \text { de 2009) }}$

$\S 5^{\circ}$ Os resultados alcançados pelo ente federado na gestão do Programa Bolsa Família, aferidos na forma do inciso I do $\S 2^{\underline{o}}$ serão considerados como prestação de contas dos recursos transferidos. (Incluído pela Lei ${ }^{\circ} 12.058$, de $\underline{\text { 2009) }}$

$\S 6^{0}$ Os Estados, o Distrito Federal e os Municípios submeterão suas prestações de contas às respectivas instâncias de controle social, previstas no art. $9^{\circ}$, e, em caso de não aprovação, os recursos financeiros transferidos na forma do $\S 3^{\mathrm{o}}$ deverão ser restituídos pelo ente federado ao respectivo Fundo de Assistência Social, na forma regulamentada pelo Poder Executivo Federal. (Incluído pela Lei $\underline{\left.\mathrm{n}^{\circ} 12.058, \text { de } 2009\right)}$

$\S 7^{\circ}$ O montante total dos recursos de que trata o $§ 3^{\circ}$ não poderá exceder a $3 \%$ (três por cento) da previsão orçamentária total relativa ao pagamento de benefícios do Programa Bolsa Família, devendo o Poder Executivo fixar os limites e os parâmetros mínimos para a transferência de recursos para cada ente federado. (Incluído pela Lei $\mathrm{n}^{\circ} 12.058$, de 2009)

Art. 9ำ O controle e a participação social do Programa Bolsa Família serão realizados, em âmbito local, por um conselho ou por um comitê instalado pelo Poder Público municipal, na forma do regulamento.

Parágrafo único. A função dos membros do comitê ou do conselho a que se refere o caput é considerada serviço público relevante e não será de nenhuma forma remunerada. 
Art. 10. $\mathrm{O}$ art. $5^{\circ}$ da Lei $\mathrm{n}^{\mathrm{o}} 10.689$, de 13 de junho de 2003 , passa a vigorar com a seguinte alteração:

"Art. $5^{\circ}$ As despesas com o Programa Nacional de Acesso à Alimentação correrão à conta das dotações orçamentárias consignadas na Lei Orçamentária Anual, inclusive oriundas do Fundo de Combate e Erradicação da Pobreza, instituído pelo art. 79 do Ato das Disposições Constitucionais Transitórias." (NR)

Art. 11. Ficam vedadas as concessões de novos benefícios no âmbito de cada um dos programas a que se refere o parágrafo único do art. $1^{\circ}$.

Parágrafo único. A validade dos benefícios concedidos no âmbito do Programa Nacional de Acesso à Alimentação - PNAA - "Cartão Alimentação" encerra-se em 31 de dezembro de 2011. (Incluído pela Lei $\mathrm{n}^{\circ} 12.512$, de 2011)

Art. 12. Fica atribuída à Caixa Econômica Federal a função de Agente Operador do Programa Bolsa Família, mediante remuneração e condições a serem pactuadas com o Governo Federal, obedecidas as formalidades legais.

Art. 13. Será de acesso público a relação dos beneficiários e dos respectivos benefícios do Programa a que se refere o caput do art. $1^{\circ}$.

Parágrafo único. A relação a que se refere o caput terá divulgação em meios eletrônicos de acesso público e em outros meios previstos em regulamento.

Art. 14. A autoridade responsável pela organização e manutenção do eadastro referido no art. $1^{\circ}$ que inserir ou fizer inserir dados ou informaçẽes falsas ou diversas das que deveriam ser inscritas, com 0 fim de alterar a verdade sobre $\theta$ fato, ou contribuir para a entrega do benefício a pessea diversa do beneficiário final, será respensabilizada civil, penale administrativamente.

$\S 1^{\Theta}$ Sem prejú́zo da sanção penal, $\Theta$ beneficiário que dolosamente utilizar $\Theta$ benefício será obrigado a efetuar o ressarcimento da importância recebida, em prazo a ser estabelecido pelo Poder Executivo, acrescida de juros equivalentes à taxa referencial do Sistema Especial de Liquidação e Custódia SELIC, e de $1 \%$ (um por cento) ao mês, calculados a partir da data do recebimento.

$\S 2^{\ominus}$ Ao servidor público ou agente de entidade conveniada ou contratada que eoncorra para a conduta ilícita prevista neste artigo aplica-se, nas condiçẽes a serem estabelecidas em regulamento e sem prejuízo das sançẽes penais e 
administrativas cabíveis, multa nunca inferior ao dobro dos rendimentos ilegalmente pagos, atualizada, anualmente, até seu pagamento, pela variação acumulada do Índice de Preços ao Consumidor Amplo IPCA, divulgado pela Fundação Instituto Brasileiro de Geografia e Estatística.

Art. 14. Sem prejuízo das responsabilidades civil, penal e administrativa, o servidor público ou o agente da entidade conveniada ou contratada responsável pela organização e manutenção do cadastro de que trata o $\operatorname{art}^{\circ} 1^{\circ}$ será responsabilizado quando, dolosamente: (Redação dada pela Lei $\mathrm{n}^{\circ} 12.512$, de $\underline{2011)}$

I - inserir ou fizer inserir dados ou informações falsas ou diversas das que deveriam ser inscritas no Cadastro Único para Programas Sociais do Governo Federal - Cadúnico; ou (Incluído pela Lei n ${ }^{\circ} 12.512$, de 2011)

II - contribuir para que pessoa diversa do beneficiário final receba o benefício. (Incluído pela Lei ${ }^{\circ} 12.512$, de 2011)

$\S 1^{\circ}$ (Revogado). $\quad$ (Redação dada pela Lei $\mathrm{n}^{\circ} 12.512$, de 2011)

$\S 2^{\circ} \mathrm{O}$ servidor público ou agente da entidade contratada que cometer qualquer das infrações de que trata o caput fica obrigado a ressarcir integralmente o dano, aplicando-se-lhe multa nunca inferior ao dobro e superior ao quádruplo da quantia paga indevidamente. (Redação dada pela Lei ${ }^{\circ} 12.512$, de 2011)

Art. 14-A. Sem prejuízo da sanção penal, será obrigado a efetuar o ressarcimento da importância recebida o beneficiário que dolosamente tenha prestado informações falsas ou utilizado qualquer outro meio ilícito, a fim de indevidamente ingressar ou se manter como beneficiário do Programa Bolsa Família. (Incluído pela Lei $\mathrm{n}^{\circ} 12.512$, de 2011)

$\S 1^{\circ} \mathrm{O}$ valor apurado para o ressarcimento previsto no caput será atualizado pelo Índice Nacional de Preços ao Consumidor Amplo - IPCA, divulgado pela Fundação Instituto Brasileiro de Geografia e Estatística. (Incluído pela Lei n $\underline{12.512, \text { de 2011) }}$

$\S 2^{\circ}$ Apurado o valor a ser ressarcido, mediante processo administrativo, e não tendo sido pago pelo beneficiário, ao débito serão aplicados os procedimentos 
de cobrança dos créditos da União, na forma da legislação de regência. (Incluído pela Lei $\mathrm{n}^{\circ} 12.512$, de 2011)

Art. 15. Fica criado no Conselho Gestor Interministerial do Programa Bolsa Família um cargo, código DAS 101.6, de Secretário-Executivo do Programa Bolsa Família.

Art. 16. Na gestão do Programa Bolsa Família, aplicarse-á, no que couber, a legislação mencionada no parágrafo único do art. $1^{\circ}$, observadas as diretrizes do Programa.

Art. 17. Esta Lei entra em vigor na data de sua publicação.

Brasília, 9 de janeiro de 2004; $183^{\circ}$ da Independência e $116^{\circ}$ da República. LUIZ INÁCIO LULA DA SILVA José Dirceu de Oliveira e Silva 


\title{
8.13.
}

\section{Anexo 13}

\section{DECRETO № 7.492, DE 2 DE JUNHO DE 2011.}

\author{
Institui o Plano Brasil Sem \\ Miséria.
}

A PRESIDENTA DA REPÚBLICA, no uso da atribuição que lhe confere o art. 84, inciso VI, alínea "a", da Constituição,

\section{DECRETA:}

Art. 1ำ Fica instituído o Plano Brasil Sem Miséria, com a finalidade de superar a situação de extrema pobreza da população em todo o território nacional, por meio da integração e articulação de políticas, programas e ações.

Parágrafo único. O Plano Brasil Sem Miséria será executado pela União em colaboração com Estados, Distrito Federal, Municípios e com a sociedade.

Art. $2^{-}$O Plano Brasil Sem Miséria destina-se à população em situação de extrema pobreza.

Parágrafo único. Para efeito deste Decreto considera-se em extrema pobreza aquela população com renda familiar per capita mensal de até $R \$ 70,00$ (setenta reais).

Parágrafo único. Para efeito deste Decreto considera-se em extrema pobreza aquela população com renda familiar per capita mensal de até $R \$ 77,00$ (setenta e sete reais). (Redação dada pelo Decreto no 8.232, de 2014)(Efeitos financeiros)

Art. 3ํ São diretrizes do Plano Brasil Sem Miséria:

I - garantia dos direitos sociais;

II - garantia de acesso aos serviços públicos e a oportunidades de ocupação e renda;

III - articulação de ações de garantia de renda com ações voltadas à melhoria das condições de vida da população extremamente pobre, de forma a considerar a multidimensionalidade da situação de pobreza; e 
IV - atuação transparente, democrática e integrada dos órgãos da administração pública federal com os governos estaduais, distrital e municipais e com a sociedade.

Art. 4º São objetivos do Plano Brasil Sem Miséria:

I - elevar a renda familiar per capita da população em situação de extrema pobreza;

II - ampliar o acesso da população em situação de extrema pobreza aos serviços públicos; e

III - propiciar o acesso da população em situação de extrema pobreza a oportunidades de ocupação e renda, por meio de ações de inclusão produtiva.

Parágrafo único. O Cadastro Único para Programas Sociais do Governo Federal, previsto no Decreto $\mathrm{n}^{0} 6.135$, de 26 de junho de 2007, será utilizado como instrumento básico para identificação do público e planejamento das ações do Plano Brasil Sem Miséria.

Art. 5ำ São eixos de atuação do Plano Brasil Sem Miséria:

I - garantia de renda;

II - acesso a serviços públicos; e

III - inclusão produtiva.

Art. 6ํㅡ Ficam instituídas as seguintes instâncias para a gestão do Plano Brasil Sem Miséria:

I - Comitê Gestor Nacional;

II - Grupo Executivo; e

III - Grupo Interministerial de Acompanhamento.

Parágrafo único. $\mathrm{O}$ apoio administrativo necessário ao funcionamento das instâncias instituídas no caput será prestado pelo Ministério do Desenvolvimento Social e Combate à Fome. 
Art. 7ํㅡㄹ Compete ao Comitê Gestor Nacional do Plano Brasil Sem Miséria, instância de caráter deliberativo, fixar metas e orientar a formulação, a implementação, o monitoramento e a avaliação do Plano.

$\S 1^{\text {o }}$ O Comitê Gestor Nacional será composto pelos titulares dos seguintes órgãos:

I - Ministério do Desenvolvimento Social e Combate à Fome, que o coordenará;

II - Casa Civil da Presidência da República;

III - Ministério da Fazenda; e

IV - Ministério do Planejamento, Orçamento e Gestão.

$\S 2^{\mathrm{o}}$ Os membros do Comitê Gestor Nacional indicarão seus respectivos suplentes.

$\S 3^{\text {o }}$ A Secretaria-Executiva do Comitê Gestor Nacional será exercida pela Secretaria Extraordinária para a Superação da Extrema Pobreza do Ministério do Desenvolvimento Social e Combate à Fome.

Art. 8 Compete ao Grupo Executivo do Plano Brasil Sem Miséria assegurar a execução de políticas, programas e ações desenvolvidos no âmbito do Plano.

$\S 1^{0}$ O Grupo Executivo será composto pelos Secretários-Executivos dos órgãos mencionados nos incisos II a IV do $\S 1^{\underline{0}}$ do art. $7^{\circ} \mathrm{o}$ e por representante do Ministério do Desenvolvimento Social e Combate à Fome, que o coordenará.

$\S 2^{\underline{o}}$ Os membros do Grupo Executivo indicarão seus respectivos suplentes.

Art. 9 Compete ao Grupo Interministerial de Acompanhamento do Plano Brasil Sem Miséria o monitoramento e a avaliação de políticas, programas e ações desenvolvidos no âmbito do Plano.

$\S 1^{0}$ O Grupo Interministerial de Acompanhamento será composto por representantes, titular e suplente, indicados pelos seguintes órgãos: 
I - Ministério do Desenvolvimento Social e Combate à Fome, que o coordenará;

\author{
II - Casa Civil da Presidência da República; \\ III - Secretaria-Geral da Presidência da República; \\ IV - Ministério da Fazenda; \\ V - Ministério do Planejamento, Orçamento e Gestão; \\ VI - Ministério das Cidades; \\ VII - Ministério do Trabalho e Emprego; \\ VIII - Ministério do Desenvolvimento Agrário; \\ IX - Ministério da Saúde; \\ X - Ministério da Educação; e \\ XI - Ministério da Integração Nacional.
}

$\S 2^{\circ}$ Os representantes de que trata o $\S 1^{\underline{o}}$ serão designados em ato do Ministro de Estado do Desenvolvimento Social e Combate à Fome.

§ 3ํㅡ O Grupo Interministerial de Acompanhamento prestará informações ao Grupo Executivo e ao Comitê Gestor Nacional sobre as políticas, programas e ações, suas respectivas dotações orçamentárias e os resultados de execução, identificando os recursos a serem alocados no Plano Brasil Sem Miséria.

$\S 4^{\circ}$ Poderão ser convidados para as reuniões do Grupo Interministerial de Acompanhamento representantes de entidades e órgãos públicos e privados, dos Poderes Legislativo e Judiciário e do Ministério Público, bem como especialistas, para emitir pareceres e subsidiar o Grupo com informações.

§ 5ํ Poderão ser constituídos no âmbito do Grupo Interministerial de Acompanhamento grupos de trabalho temáticos destinados ao estudo e à elaboração de propostas sobre temas específicos, a serem submetidos ao Comitê Gestor Nacional. 
Art. 10. A participação nas instâncias colegiadas instituídas neste Decreto será considerada prestação de serviço público relevante, não remunerada.

Art. 11. Para a execução do Plano Brasil Sem Miséria poderão ser firmados convênios, acordos de cooperação, ajustes ou outros instrumentos congêneres, com órgãos e entidades da administração pública federal, dos Estados, do Distrito Federal e dos Municípios, com consórcios públicos, bem como com entidades privadas, na forma da legislação pertinente.

Art. 12. O Plano Brasil Sem Miséria será custeado por:

I - dotações orçamentárias da União consignadas anualmente nos orçamentos dos órgãos e entidades envolvidos no Plano Brasil Sem Miséria, observados os limites de movimentação, de empenho e de pagamento fixados anualmente;

II - recursos oriundos dos órgãos participantes do Plano Brasil Sem Miséria e que não estejam consignados nos Orçamentos Fiscal e da Seguridade Social da União; e

III - outras fontes de recursos destinadas por Estados, Distrito Federal e Municípios, bem como por outras entidades públicas e privadas.

Parágrafo único. Para fins de acompanhamento do cumprimento do disposto no inciso I deste artigo, os órgãos e entidades participantes do Plano Brasil Sem Miséria deverão proceder à execução orçamentária utilizando Plano Interno - PI específico no Sistema Integrado de Administração Financeira do Governo Federal - SIAFI.

Art. 13. Este Decreto entra em vigor na data de sua publicação.

Brasília, 2 de junho de 2011; 190º da Independência e 123ํ da República.

\section{DILMA ROUSSEFF}

Tereza Campello

Este texto não substitui o publicado no DOU de 3.6.2011 